Marcio de Lima Pacheco

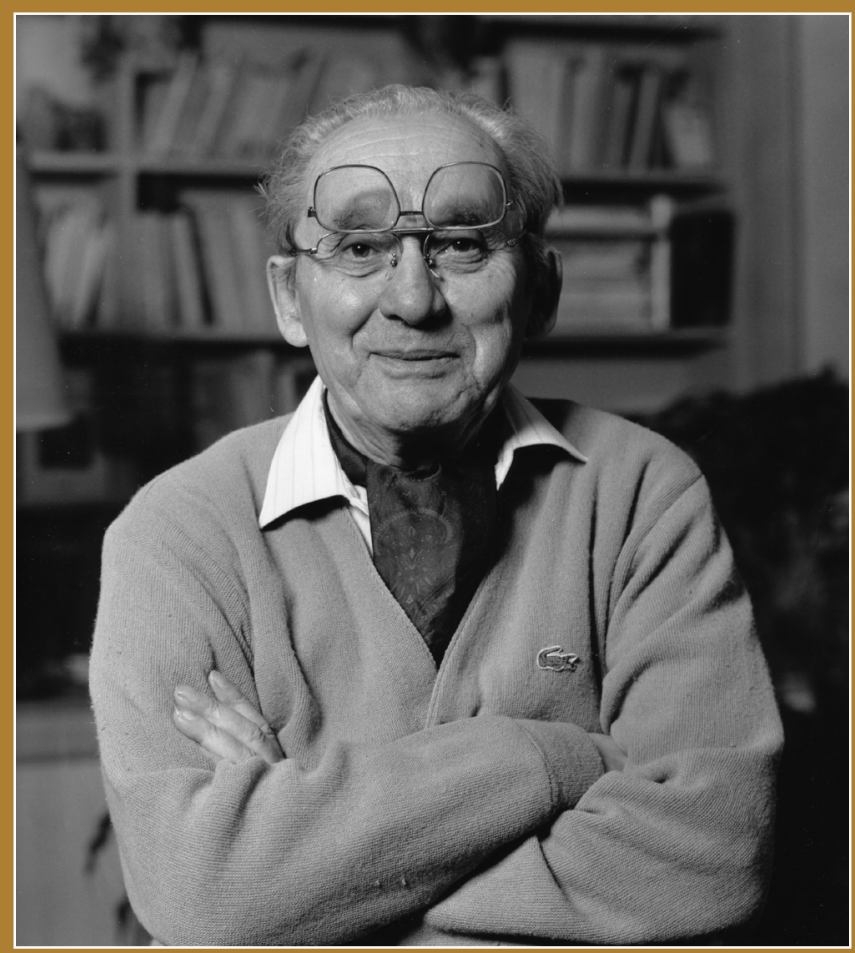

\title{
A ESPERANÇA COMO MOVIMENTO DA EXISTÊNCIA: UMA LEITURA RICOEURIANA
}

Coleção Pós-Graduação da UNIR

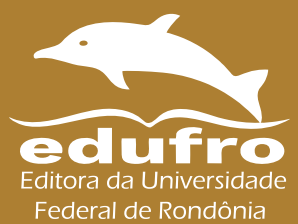




\section{A esperança como movimento da existência: uma leitura ricoeuriana}

Marcio de Lima Pacheco 
FUNDAÇÃO UNIVERSIDADE FEDERAL DE RONDÔNIA

Reitora Marcele Regina Nogueira Pereira

Vice-Reitor José Juliano Cedaro

EDITORA DA UNIVERSIDADE FEDERAL DE RONDÔNIA

\section{CONSELHO EDITORIAL}

Presidente Lou-Ann Kleppa

Ariana Boaventura Pereira

Carlos Alexandre Trubiliano

Eliane Gemaque Gomes Barros

Gean Carla Silva Sganderla

Leandro Soares Moreira Dill

Márcio Secco

Marli Lúcia Tonatto Zibetti

Pedro Ivo Silveira Andretta

Ricardo Gilson da Costa Silva

Xênia de Castro Barbosa

\author{
COMISSÃO CIENTÍFICA \\ Marília Lima Pimentel Cotinguiba \\ Carlos André da Silva Müller \\ Gabriel Eduardo Melim Ferreira \\ Wanderley Rodrigues Bastos \\ João Paulo Assis Gobo \\ Patrícia Goulart Tondineli \\ Lucas Martins Gama Khalil \\ Quesler Fagundes Camargo \\ Estevão Rafael Fernandes \\ Élcio Aloísio Fragoso
}

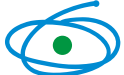

CAPES

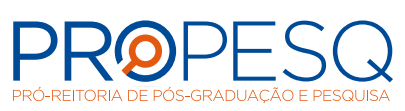

Editora Filiada

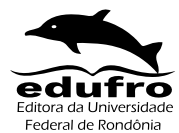

Federal de Rondônia

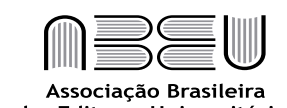

das Editoras Universitárias

Edufro - Editora da Universidade Federal de Rondônia

BR 364, Km 9,5

Campus Unir

76801-059 - Porto Velho - RO

Tel.: (69) 2182-2175

www.edufro.unir.br

edufro@unir.br 


\section{A esperança como movimento da existência: uma leitura ricoeuriana}

Marcio de Lima Pacheco

Coleção Pós-Graduação da UNIR

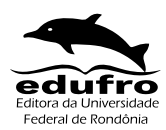

Porto Velho - RO 
(C) 2021 by Marcio de Lima Pacheco

Esta obra é publicada sob a Licença Creative Commons Atribuição-Não Comercial 4.0 Internacional.

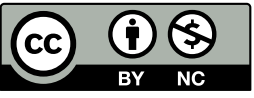

\author{
Capa: \\ Rosivan Diagramação \& Artes Gráficas
}

Revisão:

Marília Lima Pimentel Cotinguiba

Revisão de Língua Portuguesa:

Prof. Dr. Francisco de Assis Costa da Silva (UERN)

Projeto gráfico:

Edufro - Editora da Universidade Federal de Rondônia

Diagramação:

Rosivan Diagramação \& Artes Gráficas

Dados Internacionais de Catalogação na Publicação

Fundação Universidade Federal de Rondônia (UNIR)

Ficha Catalográfica elaborada pela Biblioteca Central da UNIR

P116e Pacheco, Marcio de Lima.

A esperança como movimento da existência: uma leitura ricoeuriana / Marcio de Lima Pacheco. - Porto Velho, RO: Coleção Pós-Graduação da UNIR - EDUFRO, 2021.

$192 \mathrm{p}$.

ISBN: 978-65-87539-44-7 (digital)

1. Filosofia. 2. Linguagem religiosa. 3. Filosofia da Religião. I. Marcio de Lima Pacheco. II. Titulo. III. Fundação Universidade Federal de Rondônia.

CDU 17:2-1 
Prefácio:

\section{Moacyr Grechy. O.S.M}

É importante falarmos de esperança nos tempos hodiernos, pois o mundo vive uma desesperança sem medida. Desesperança gerada pelo individualismo, arrogância, egoísmo, intolerância, a falta de liberdade e o mal. É importante sempre ressaltar que torna-se necessário sempre voltarmos ao antecedente da justificação bíblica, como via ontológica, para notarmos como a esperança é uma abertura ontológica, pois, como diz-nos Ricoeur (1992, p. 111): "o passado é um cemitério de promessas não cumpridas, que se trata de ressuscitar ao modo dos ossos do vale de Josapha na profecia de Ezequiel". É necessário, pois, compreender a crise da consciência histórica, não apenas à luz da retomada do potencial de esperança do passado, como promessas não cumpridas, mas de uma preocupação com o vazio de objetivos de nosso horizonte de expectativa ética em nossa época.

Sobretudo, hoje, devemos estar animados pela esperança de uma reconciliação, porque é um "movimento da liberdade para a natureza que se exige-se a necessidade e a converter em si-próprio" (RICCEUR: 1988, p. 351, 325). Faz útil notar que pensar sob o signo da esperança envolve a possibilidade de uma ontologia reconciliada face a uma ontologia paradoxal, que parece ser o grande desafio desta filosofia da vontade: ontologia da liberdade e da Transcendência, como reconciliação poética e criativa no seio da desproporção humana.

Ao que me parece, o jovem autor desse livro, o professor Dr. Marcio de Lima Pacheco, na linha ricoeuriana e, porque não dizer marceliana (em minha estadia em Roma de 1955 à 1961, li muito Gabriel Marcel e Jürgen. Moltmann para compará-los com a filosofia cristã), mostra que o primeiro passo de uma filosofia da esperança, é a renúncia de uma razão especulativa e sua pretensão de concluir o conhecimento em objetos empíricos. Assim, a esperança reenvia para algo além das condições objetivas da verificabilidade. Ela rompe os limites de uma evidencia especulativa que se dá através de uma exigência prática. A esperança instaura um sentido da história e/ou da existência que é da ordem do mysthérium, ou seja um sentido sobre-racional e sobrenatural. Ela é, propriamente a exorcização do desespero humano. Ela é que é o sentido oculto de um sentido aparente sem que haja um utopismo futurológico. A esperança é, ao mesmo tempo, irracional, porque existe e exerce-se apesar dos antagonismos, do sofrimento e da morte e para além do desespero, e racional na medida em que afirma a lei da sobre abundância ,nas palavras paulina, do sentido escondido.

Esse sentido é o que devemos resgatar em nossos tempos para vivermos uma filosofia e uma teologia da esperança longe de ficticíssimos que atrapalha a grande maioria dos homens principalmente em seu relacionamento ético.

É importante, a medida que lemos esse livro, pensarmos. O que é a esperança para mim e para o outro? Em que ponto, ela desemborca ou propriamente cruza com a encarnação? Em que momento eu sou um ser ético e com esperança?

Certamente, a leitura desse livro, será uma grande viagem pela filosofia hermenêutica, com outros autores que o próprio autor cita ao longo do texto para o nosso deleite. In boca al lupo (al auctore). Crepi il lupo

Pode-se imprimir. 12 fevereiro de 2017.

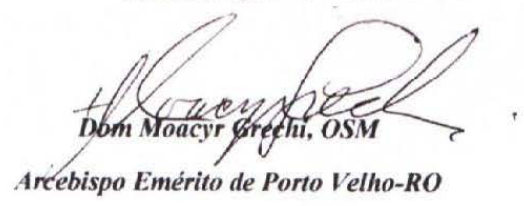





\section{Sumário}

9

INTRODUÇÃO

19

Por que a partir do mal, temos um acesso concreto à Transcendência?

$22 \quad 1.10$ problema do Mal

22 1.1.1. Existe uma conciliação entre o mal e a liberdade?

27 1.1.2. O simbolismo da mancha desperta o olhar ético em nós

31 1.2. Existe uma incompatibilidade entre o mal e uma ética

39 1.2.1. A desesperança ético-religiosa

491.30 livre-arbítrio e a justificação

521.4 No mal há um sentido existencial

$54 \quad 1.4 .10$ sentido e o Mito Adâmico

$56 \quad 1.50$ ser e a história

59 1.6. Existe um Deus mal na da visão trágica da existência?

76 A linguagem religiosa portadora de uma esperança "filosófica".

782.10 símbolo como ponto de partida da reflexão sobre linguagem religiosa

$88 \quad$ 2. A Fé e a Religião

892.0 recurso à linguagem religiosa

94 2.1 A análise filosófica da linguagem religiosa

96 2.2- A manifestação e a proclamação como linguagem religiosa a partir de uma perspectiva filosófica.

99 2.3. A poética e a linguagem religiosa

1042.4 A linguagem religiosa e sua especificidade como linguagem que expressa fatos da existência humana

114 3. Entre a hermenêutica filosófica e a teológica: o fundamento da esperança

116 3.1. A Palavra: como ponto central do Cristianismo e dos procedimentos filosóficos diante de uma hermenêutica filosófica

117 3.2. O evento histórico e o evento da palavra em relação ao discurso 
119 3.2.1. As contribuições dos estudos filosóficos e linguísticos para a Teologia da palavra

124 4. A Revelação e Testemunho: pensar e o recuperar a experiência humana a partir do símbolo

139 6. A palavra e a demitologização

142 6. Entre a Filosofia e a teologia: A esperança como afirmação originária dentro da Linguagem Poética e do Testemunho

\section{A esperança no evento da Ressureição}

149 3. A Esperança e seu sentido para existência humana

156 4. A esperança de Gabriel Marcel em na esperança de Ricoeur

1593.10 consentimento

162 3.1.1 Consentimento e Esperança

1653.1 .20 consentimento e o Mal

167 3.2 Esperança e a Escatologia Cristã

1725 A Esperança e sua abertura à história

\section{CONCLUSÃO}

\section{Referências}

184 1. Obras de Paul Ricoeur consultadas

186 2. Autores Consultados

192 Sobre o autor 


\section{INTRODUÇÃO}

Este livro é dedicado ao público em geral. Principalmente nesse contexto pandêmico no qual somente percebemos desesperança. A partir desse livreto, o leitor pode se lançar na investigação sobre a esperança filosófica, ou melhor, uma filosofia da esperança, sem aquele ranço de imaginar que filosofia é difícil.

O tema é, por demais, bastante próximo a todos, pois, parafraseando Camus (2007, p. 75): Tudo que o homem faz, vive, utiliza a esperança. Ela é o único pensamento que não é enganador e, portanto, um pensamento estéril. No mundo absurdo, o valor de uma noção ou de uma vida mede-se pela sua infecundidade.

O leitor se deparará, em diversos momentos, desse escrito, a pensar sobre a sua própria existência e esperança. Isso é tanto verdade que, aquele que lê, desemborcará na mesma, certeza de Antônio Vieira: mata a esperança, que é o último remédio que deixou a natureza a todos os males

Em nossos tempos, a esperança é uma condição de abertura, ou melhor movimento ao horizonte, que transcende o mundo. Conforme Paul Ricoeur (2006, p. 110) : "A esperança não é um tema que vem depois dos outros temas, a ideia que fecha o sistema, mas um impulso que abre o sistema, que rompe o encerramento do sistema: é uma maneira de reabrir o que fora indevidamente fechado".

Um evento, nada mais é que que não seja um tempo relativamente curto a um determinado tipo de acontecimento da história, mas é tudo o que produz, de certa forma, uma mudança dentro da narrativa. Esse acontecimento é capaz de mostrar o início e o fim do determinado acontecimento ou mesmo acrescer um novo relato ou ponto daquela história.

Sendo a ressurreição o evento que pode nos animar a ter uma esperança, apesar de todo mal, ela desvela o reverso da queda adâmica, pois como metáfora, ela é um movimento que reorienta a existência humana, um laço que une o mito adâmico ao núcleo "cristológico" da fé é um laço de conveniência: a descrição simbólica do homem, na doutrina do pecado, convém ao anúncio da salvação. 
Além do mais, a ressurreição do passado a partir de uma reencarnação do Outro em uma imediaticidade emocional. Em sentido inverso, nossa dupla de autores prefere a análise, isto é, a decomposição do passado em categorias de inteligibilidade, assim como a busca de relações causais entre as partes.

Formalmente, o lemos a partir da articulação e correlação que ele mesmo faz entre a filosofia e a teologia. Trata-se então de um olhar que o filósofo pode ter sobre a teologia, que se deixa guiar, sem perder a autonomia da reflexão filosófica, pela vinculação que se estabelece entre essas suas disciplinas. Se se quer transitar de uma disciplina a outra tem-se que ir pelas pontes construídas pelo próprio Ricoeur nos textos a que nos propomos. Os vínculos, as relações que o autor estabelece são contribuições de sua hermenêutica filosófica sobre a hermenêutica teológica.

Nesse momento nos fixamos em especial sobre sua reflexão sobre o mal como uma via concreta à Transcendência, sobre a linguagem religiosa e sobre a questão do consentimento que desemborca em uma esperança escatológica. Notoriamente essa delimitação implicou analisar e estudar os artigos dedicados à questão da hermenêutica filosófica, hermenêutica teológica e linguagem religiosa.

Existe a tentação de ler Ricoeur a partir de todas as tradições que o formaram (fenomenologia, filosofia reflexiva, hermenêutica), o que é impossível e inviável. Tampouco nos dedicaremos aos teólogos que alimentam suas reflexões. Por isso foi necessário selecionar a vastíssima bibliografia secundária.

A nossa tese consiste em mostrar que em Ricoeur existe uma esperança como movimento da existência no Evento da Ressurreição, não que ele faça uma interpretação da esperança, mas em sua hermenêutica há indícios de que ainterpretação dos textos sagrados, dos símbolos e dos mitos é conduzida por uma esperança e que essa se constitui um lugar filosófico no seu pensamento ético. Àluz dos seus escritos, a esperança é o conector que articula de maneira excelente, sem confundir ou separar, o campo filosófico e o campo teológico. $\mathrm{O}$ cenário dessa articulação é a perspectiva do kerygma cristão da esperança com a questão “Que me é permitido esperar?”(RICOEUR, 2006, p. 67).

Nessa nossa proposta, o pensamento de Ricoeur não vem reduzido a um sistema, mas polarizado ao redor dos temas, como: mal, esperança, evento, anúncio, 
hermenêutica filosófica e teológica, constantes ao longo das etapas do desenvolvimento de seu pensamento no amplo leque de perspectivas em que se desdobra.

Esse estudo busca, então, colher um aspecto do pensamento de Ricoeur de influência decisiva na sua forma e substância. Buscando no motivo ético-religioso ricoeuriano o princípio de uma hermenêutica da esperança, a tese tende a preencher o vazio que existe entre o que é dito é o que é percebido por um leitor mais apurado nesse interesse específico. A interpretação dos textos de Ricoeur permite individuar certos pressupostos do seu filosofar.

A reflexão filosófica de Paul Ricoeur nasceu e amadureceu no confronto e diálogo constante com as várias expressões do pensamento da história ocidental. Os pensadores da antiguidade e os contemporâneos encontrarão um observador atento, um interlocutor, um crítico competente e respeitoso.

Dialogando com os pensadores de todos os tempos, Ricoeur não é um eclético que recolhe quanto há de melhor no pensamento, mas se aproxima desse a fim de recriá-lo de alguma forma. $\mathrm{O}$ elemento unificador que the permite harmonizar as expressões de pensamento tidas como irreconciliáveis é a sua constante busca da mediação do conflito nas diversas filosofias, "de buscar relações entre todas as totalidades parciais” (RICOEUR, 1968, p. 46). A esperança tem por função manter o diálogo sempre aberto nos debates mais ásperos. Nesse sentido, ela é justamente o ambiente vital da comunicação, a luz de todos os debates. "A história[do homem] permanece polêmica, mas como que aclarada por esse eschaton que a unifica e eterniza sem se poder coordenar com a história (...) a unidade do verdadeiro não é tarefa intemporal, senão por ser antes de mais nada uma esperança escatológica” (RICOEUR, 1968, p. 60).

A variedade do itinerário filosófico de Ricoeur, que faz pensar em uma filosofia sem um fim específico, conduz a um elemento unificante: uma esperança que tem como base uma dimensão ético. Essa aparece dos modos mais diversos e nos momentos improváveis como uma pequena ilha, que no mar se revela um continente que está no fundo e que a ela se liga.

Não é que uma dimensão ético-religiosa seja o fundo principal do pensamento ricoeuriano. É algo que de quando em quando se revela no pensamento desse filósofo, mesmo que não expressamente e que permanece como um horizonte do seu pensamento. 
A esperança dentro de uma dimensão ético e porque não religiosa e em toda obra de Paul Ricoeur não tem um status de categoria fundamental que aclara e renova todo um setor do pensar, como é o caso da ipseidade, da identidade narrativa, da configuração e reconfiguração, do mundo do texto entre outras. Também não intervém na obra da sua maturidade. É um tema que surge no interior da sua obra através de temas que tocam a existência humana como: omal, a falta, a culpa, a escatologia, liberdade, a fé, religião, a linguagem.

Mais que uma categoria, a esperança é um tema ou mesmo uma noção que pode ser definida como um plano inteligivelmente específico, uma intencionalidade irredutível, algo a que se refere. Ele mesmo intitula um dos seus textos como O Conflito das Interpretaçôes (1999).Claro que é necessário a análise dos símbolos do mal, que vão dos símbolos do início ao símbolos do fim. Tal como se revela a figura do Cristo, como símbolo último, último Adão em comparação com aquele primeiro. É necessário abandonar uma lógica sensata para indagar, para dar vez a uma história sensata em um abandono a uma inteligência da esperança, na qual o mal, na linguagem bíblica, coloca-se diante de uma lógica da superabundância, o quanto mais que se dará em uma dimensão escatológica no evento da Ressurreição.

Em Ricoeur a história do bem é fonte do mistério do mal. O problema dos grandes mitos é saber dar voz ao ato de confiança original, pois por mais radical que seja o mal, o mito do gêneses no diz que, a bondade é ainda mais radical, ou seja se o mal é radical, a bondade é original. Quanto à prevalência, na reflexão, da destinação fundamental à bondade e a justiça, ela é preside o projeto de aperfeiçoamento da espécie humana.

Um discurso concreto e total sobre o mal no homem não é possível, pois só se pode tomar nota da experiência do mal se voltarmos para as formas dessa experiência na existência humana. Especialmente na busca de uma superação da questão do "injustificável”, que é o mal, a dimensão religiosa entra na reflexão filosófica. É nesse momento que a esperança toma relevo determinante na reflexão sobre o mal no homem e no mundo.

De uma parte o homem se dá conta de sua culpa através dos símbolos e mitos, esses nos oferecem um discurso para indagar o imperscrutável, 
que são para ele o mais alto legado no âmbito religioso da sua experiência humana. De outra, também o caminho que faz notar a sua culpa está na direção da esperança que recorda o destino transcendente do homem e o seu cumprimento escatológico.

A promessa nesse cumprimento a partir do evento da Ressureição, cria uma esperança de um reino que virá. Consequentemente, cria uma história, a história da salvação de uma liberdade confiada a um Deus que vem e torna tudo radicalmente novo, isso é uma imaginação criadora do possível. Assim, a liberdade segundo a esperança é uma liberdade que está aí, apesar da morte. Esse apesar de é uma categoria que exprime a lógica da superabundância e define a natureza humana capaz de ser livre da morte.

A perspectiva escatológica em particular é essencialmente religiosa. Uma vida ética recorda a boa nova do Reino de Deus que se realiza concretamente na figura do Cristo. A "filosofia da fé" e da religião, entretanto, é outra coisa. A fé é "aquilo que a teologia ordena no foco cristológico do testemunho, a filosofia da religião ordena-o (refere-o ao) no desejo de ser do homem"(RICOEUR, 1999, p. 337).

Para o filósofo, o Cristo, mais que realidade a testemunhar, é esquema de esperança. Cristo resulta duma imaginação mítico-poética concernente ao cumprimento do desejo de ser. Ora, isto não basta absolutamente ao teólogo. Já “o filósofo nada tem a dizer, quanto à proclamação, ao kerygma apostólico segundo o qual essas figuras (justo sofredor, Rei Messias, Filho do Homem) são realizadas no acontecimento de Jesus Cristo. Mas ele pode e deve refletir sobre esses símbolos enquanto representações do fim do mal” (RICOEUR, 1977, p. 47).

Em Ricoeur, o sagrado e a revelação cristã não tomam o posto da reflexão, substituindo a razão pela fé. A Revelação como palavra significativa, voltada para o homem, está dentro de um processo racional, que não exclui uma relação entre fé e razão. Assim, em nosso filósofo, não há uma subordinação da razão à fé do tipo gnóstico. Afirma ele querer conduzir uma reflexão filosófica no limite da razão, porém em toda razão.

A meditação e a superação são realizadas em uma dimensão mais profunda que não aquela fenomênica, pois a unidade da verdade somente pode ser 
entendida na profundidade do ser. Entretanto, a conciliação que se realiza no tempo histórico não pode ser parcial, nem provisória. A esperança tem a tarefa de manter o homem no caminho de uma contínua meditação que se cumprirá somente no horizonte escatológico, para além do tempo presente. E essa esperança é de natureza transcendente, religiosa, não laica, imanente aos eventos da história do homem, e estreitamente ligada ao desenvolvimento da fé.

Ricoeur vê nos eventos da encarnação e da ressureição de Cristo o sinal religioso fundamental da fidelidade do homem e da necessidade de oferecer uma saída em direção à transcendência. Esta sua conviç̧ão não o isola do mundo cultural moderno, antes ele se interessa pelo homem para encontrar o fundo da crise que o envolve e ajudá-lo a realizar o seu desejo de ser.

$\mathrm{O}$ aspecto enigmático e racionalmente injustificável do mal no mundo mortifica a razão humana. Dessa forma, o homem é tentado a minimizar o alcance do mal ou simplesmente ignorá-lo. Mas com isso o problema que continuamente se enfrenta na experiência humana não é de fato resolvido. Acrescenta-se que o homem tem a impressão que o mal o domina, o transcende e, portanto, que não possa ser superado.

O homem se sente também responsável pelo mal, pois o mal penetrou no mundo pelo homem, e ele não é apenas vítima. Essa consciência de responsabilidade vem da experiência da liberdade. Do mal que é livremente posto, que "não é aferido pela imputação de um agente responsável, mas pela violação objetiva de um interdito" (RICOEUR, 1968, p. 336) e pelo qual se sente manchado, sujo: "A mácula (...) é o símbolo do mal" (RICOEUR, 1968, p. 197). O homem, então, pede para ser libertado desse estado, pois entende que esse estado contrasta com o seu destino de felicidade.

A questão do mal permanece uma questão que o homem não pode ignorar, porque é algo muito próximo e é uma realidade que não o deixará tranquilo enquanto não encontrar uma solução, ao menos inicial. A razão por si mesma não pode entender o mal, nem mesmo oferecer uma solução definitiva. No entanto, essa pode ser vislumbrada em uma esfera do sagrado, que é a Transcendência, à qual o mal se refere como pecado, como ruptura de uma aliança (símbolo de uma relação pessoal) de amor. 
Diante da experiência da culpa, o homem invoca a liberdade do mal das profundezas do seu ser. $\mathrm{O}$ homem vê que não pode iludir-se e alcançar, com suas forças, uma conciliação total e definitiva no tempo presente. Então, é enviado para um além que somente pode ser esperado, em um futuro, no qual se encontra uma esperança. Ricoeur nota acertadamente que a falta de limite ao recurso de uma dimensão total e definitiva da existência humana é radicada em uma ontologia paradoxal, liberdade e natureza, na qual não é possível que seja secretamente reconciliada. É aqui que nasce o recurso à esperança, pois essa torna possível a reconciliação da consciência com a sua condição, assumindo no mesmo gesto o reconhecimento humilde de suas limitações.

A esperança não é uma fuga porque por ela não deixa o ser para se refugiar noutra coisa qualquer. A esperança não é uma abstração desencarnada porque está comprometida com o consentimento e, neste sentido, o consentimento representa a experiência vivida da esperança.

A paciência imanente - aquela que reside no jogo - é a figura da esperança que transcende. Assim a esperança não é o triunfo do dualismo, mas o viático sobre o caminho da conciliação. Ela não se separa, mas compromete-se. Ela é a alma misteriosa do pacto vital que eu posso ligar com o meu corpo e o meu universo (RICOEUR, 1950.p. 452).

Ao homem não resta outra possibilidade que uma contínua mediação, uma vez que a reconciliação não está dentro de sua capacidade nem no espaço de tempo de sua vida terrena. A reconciliação total e definitiva se oferece ao homem somente como horizonte de um caminho nunca interrompido, no qual, continuamente se busca uma mediação dos conflitos, que leva uma perspectiva escatológica. A unidade total não é imanente à história e ao homem, mas ao homem é possível trabalhar tais conflitos por toda sua vida, sustentado pela esperança que dá uma dimensão nova para liberdade.

Essa nova dimensão para liberdade é um caminho que Ricoeur chama de "viver filosoficamente a esperança" (RICOEUR, 1968. p. 11). Nesse viver a tremenda contradição do paradoxo humano e do paradoxo da liberdade não se aniquilam, porque é "possível converter em tensão viva essa mortal con- 
tradição" (RICOEUR, 1968. p. 11). Somente assim o homem não sucumbe definitivamente à derrota que o mal impõe à sua razão e à sua vida. Somente vivendo essa contradição o homem consegue encontrar outros caminhos que possam tornar possível uma resposta ao problema do mal, sem que seja sempre e somente um enigma injustificável.

Se é verdade que "o fracasso de todas as teodiceias, de todos os sistemas concernentes ao mal atesta o fracasso do saber absoluto no sentido hegeliano" (RICOEUR, 1977. p. 422), é também verdade que "todos os símbolos dão a pensar, mas os símbolos do mal mostram de uma maneira exemplar que há sempre mais nos mitos e nos símbolos do que toda nossa filosofia" (RICOEUR, 1977. p. 421). Assim sendo, é possível uma aproximação ao mal pelo vasto mundo dos símbolos e dos mitos, mas também por aquele kerygma pelo qual a inteligência de temas limiares não sucumbe mais ao fracasso do mal, antes ajuda a razão sem humilhá-la.

A inteligência perante temas limiares recupera, assim, do âmbito do sagrado e do símbolo, todos aqueles elementos que possam ajudar a razão humana na busca de uma resposta e de uma superação do problema do mal. A mesma necessidade que impulsiona o homem "é o símbolo racional mais alto que esta inteligência da esperança engendra" (RICOEUR, 1999.p. 309) em uma dimensão religiosa e escatológica.

Não dissimulo como é frágil essa articulação, numa filosofia da reflexão, entre as figuras do espírito e os símbolos do sagrado. Em face de uma filosofia da reflexão, que é uma filosofia da imanência, os símbolos do sagrado aparecem apenas mesclados às figuras do espírito com grandezas culturais. Mas, ao mesmo tempo, esses símbolos designam o impacto na cultura de uma realidade que o movimento da cultura não contém. Eles falam do Todo-Outro inteiramente diferente de toda história. Dessa maneira, exercem sobre toda a sequência das figuras da cultura uma atração e um apelo (RICOEUR, 1977. p. 422).

A esperança atua aqui como razão reguladora da reflexão, pois a unidade final do verdadeiro é o próprio espírito da razão. Consequentemente é possível pensar na consonância dos múltiplos sistemas filosóficos num Uno que unifica 
numa história as singularidades filosóficas. Esse Uno é o que se acha em questão em toda questão, o que suscita a questão, mas não é nem uma filosofia particular pretensamente eterna, nem a fonte das filosofias, nem a identidade daquilo que elas afirmam, nem o vir a ser como lei imanente dos momentos filosóficos.

Esse tema, central na obra de Ricoeur, tem uma relevância especial para a ontologia, a ciência do princípio e fim de todas as coisas, por causa da finitude do homem e de seu caráter existencial. Compreender essa hermenêutica da esperança e como se processa a dimensão ético-religiosa é transportar-se para uma outra vida dos acontecimentos históricos. A compreensão histórica coloca assim em jogo todos os paradoxos da historicidade: como é que um ser histórico pode compreender historicamente a história? Como é que a vida, ao se exprimir, pode objetivar-se? Como esse objetivar-se traz à luz do dia significações susceptíveis de serem retomadas e compreendidas por outro ser histórico que supera a sua própria situação histórica? Só se tem uma saída. Se a vida não é originalmente significante, para Ricoeur a compreensão é impossível para sempre.

É necessário nesse introito apresentar, ainda que brevemente, os passos desse trabalho, pois o caminho que escolhemos para nossa abordagem resultou em três momentos que poderão ser lidos tanto em conjunto como separados, todavia, sem que se perca o sentido. Em um primeiro momento, procurou-se refletir sobre o mal como acesso à transcendência, pois o mal é um problema para o filósofo somente na medida em que pertence à problemática da atualização da liberdade. Logo, uma liberdade real só pode ser esperada além de uma sexta-feira santa, ou seja, deve ser visada no acontecimento da ressurreição do Cristo, em termos de promessa e de esperança. Pretende-se assim pensar sob o signo da "esperança": a possibilidade de uma ontologia reconciliada face a uma ontologia paradoxal parece ser o desafio desta filosofia da vontade: ontologia da liberdade e da Transcendência, como reconciliação poética e criativa no seio da desproporção humana.

Em um segundo momento, procuraremos refletir sobre a linguagem religiosa na poética de Ricoeur. Pode-se notar que o procedimento hermenêutico de Ricoeur em sua obra, no confronto dos mitos e da linguagem religiosa, compreende três etapas: da semântica, da reflexão e da ontologia. Seguindo 
essas três etapas, nosso filósofo mostra que o Sagrado radicaliza e faz com que o onírico e o poético sejam identificados. O Sagrado, ainda, coloca o homem em relação de deslocar o centro do sentido para a Transcendência.

Dessa forma, Ricoeur privilegia a simbólica do mal porque ela é estritamente conexa com a problemática da Transcendência e, também, é a que mais se assemelha com a ética de sua filosofia.

A linguagem religiosa oferece a garantia de acolhimento da Revelação como palavra inacessível e faz com que o homem decida por essa como um dom gratuito. Ela "redescreve" a realidade, mas a escutando por meio de uma linguagem metafórica e dos símbolos. Esse "redescrever" nos ajuda a evitar a ilusão de uma linguagem ou de um significado absoluto.

Em um terceiro momento, mostraremos que a esperança não é um conceito, um simples sentimento ou mesmo uma abstração. Ela está ligada à liberdade. Pois uma visão ética do mal, em relação a liberdade, é limitada por uma visão trágica do mal. Por isso é necessário acercar-se da vida concreta do homem através dos sinais da esperança. Para tanto, será necessário mostrar o sentindo da esperança para existência humana, perpassar pelo que se entende por esperança cristã e desta forma nos acercarmos do que seja uma esperança escatológica. 


\section{Por que a partir do mal, temos uma acesso concreto à Transcendência?}

O mal e a esperança são mais solidários do que o pensaremos jamais $(C I, 412)$.

Esse primeiro capítulo versará sobre o mal, mais precisamente, como a partir do mal temos um acesso à Transcendência. Para tanto, utilizaremos como base a A Filosofia da vontade: 1) Finitude e Culpabilidade 2) A simbolica do Mal.

Um dos temas que essas obras tratam e que nos servirá imensamente é o problema do mal, não a partir da investigação clássica da teodiceia, mas a partir do drama humano. A proposta do autor é fazer um caminho através da liberdade do homem, apesar do absurdo do mal, indo às raízes mais profundas através dos símbolos mais primitivos. Ricoeur, em suas obras, conduz sua pesquisa no confronto de perspectivas opostas, para daí extrair uma gradação racional que é, por assim dizer, plataforma de desenvolvimento racional que permite o recolhimento dos elementos de ambas perspectivas para fazer uma arbitragem entre as múltiplas vias. Em suma, Ricoeur vai aos lugares de interseção e no lugar onde esses não existem, ele constrói pontes entre os domínios das diversas intepretações.

O tema do mal, em Ricoeur, é um dos mais relevantes, pois é através dele que o filósofo francês visa constituir um acesso concreto à Transcendência e, principalmente, à questão da esperança. Ao mesmo tempo que está na origem da sua fenomenologia-hermenêutica, o mal faz parte da ontologia humana, ao contrário da questão do esperar ou desesperar. A meditação sobre o mal em $A$ Filosofia da vontade: 1) Finitude e Culpabilidade 2) A simbolica do Mal não é somente para desembaraçar duas noções, finitude e culpabilidade, antes se propõe indicar a problemática concreta que une a existência humana e a Transcendência em uma experiência única. Isso se dá pela tentativa que Ricoeur faz de articular o mal e a liberdade em uma relação de reciprocidade que manifesta a desesperança ética cuja afirmação permanece inteiramente aberta à Transcendência, graças ao desejo de justificação, principalmente diante da injustificabilidade do mal. 
Antes dessas duas obras, Ricoeur em Karl Jaspers et la Philosobie du Mystère de lexistence já comentava que o quadro que se situa uma filosofia da existência dentro da filosofia do sujeito a qual ao descrever esse sujeito, recupera o direito de pleitear as ideias socráticas contra uma ontologia dramática, a de Pascal contra a de Descartes e a de Kierkegaard contra Hegel.

É interessante notar que em Karl Jaspers mostra que a filosofia existencial parte da intuição cartesiana do sujeito que superar o erro de assimilar o sujeito ao objeto, em quanto coisa - res -perdendo a sua especificidade. Diferente de Jaspers em Kant, o pensamento não é um objeto, mas uma consciência geral.

Depois de Kant, Hegel é o fim da filosofia ocidental concebida como saber universal, total e sistemático. Uma construção esplendida, de um imponente palácio que é construído, mas não é habitado.

Ricoeur coloca que a filosofia de Jaspers coloca uma abertura da problemática existência para uma metafisica. Sendo que o peso principal da metafisicanão porta o drama interior da liberdade que outros antes de Jaspers chamaram graça a predestinação: o esforço principal de Jaspers leva a descoberta de uma dimensão propriamente metafisica do mundo.

Antes de prosseguimos é necessário vermos dois conceitos chaves que Ricoeur toma de Jaspers, existência e transcendência. Existênciaempírica é configurada para Jaspers, como Existenze Daisein. O primeiro termo se refere como ser possível, o segundo como existência empírica, ou seja, diz respeito ao homem, ao mundo, aos objetos objetivamente falando. Já o termo transcender está relacionado a ultrapassar o Dasein, isto é, exceder a orientação do mundo. Em outras palavras, o ato de estar além dos limites humanos e os transcender.

$\mathrm{O}$ acesso à Transcendência é fornecido por aquilo que se pode chamar de "abordagens da justificação", que se refere às condições indispensáveis à cessação do mal. Conforme Ricoeur, pensar corretamente o fim do mal somente é possível se o mal contingente for pensando em uma totalidade significante que the confira certa necessidade. A esperança, para Ricoeur, é capaz de realizar essa condição. Ela reconcilia duas interpretações irredutíveis e antagônicas da vida: a visão moral e a visão trágica do mundo em uma história coerente e não mais em uma história trágico-lógica do ser, que vai da queda à redenção. 
É interessante notar que para Ricoeur, não poderíamos nos acercar a uma noção de mal apropriada somente por uma antropologia de caráter filosófico, pois haveria tantas noções do mal que nos perderíamos entre elas. Nosso filósofo, descrevendo as estruturas puras do Voluntário e do Involuntário, funda uma base que permite escapar à ontologização gnóstica do mal, relacionando a falta como acontecimento, queda, acidente. Ele mostra as estruturas finitas do homem que permitem se opor ao peso que o Ocidente teve na concepção de homem e do mal.

Examinaremos alguns pontos que consideramos pertinentes a uma esperança na filosofia de Paul Ricoeur. Ele parte do estudo dos textos bíblicos de feição narrativa, proféticos, apocalípticos e míticos em que o homem é colocado desnudo perante a sua finitude. Essa finitude choca-se com o mistério do mal, encontra a Transcendência e, por fim, gera a esperança.

O primeiro ponto que teremos que abordar é a problemática do mal, na qual o homem é o espaço da manifestação do mal. Assim, abordaremos a relação mal/liberdade no esforço de compreender um pelo outro.

Partiremos em seguida para o segundo ponto, que é o paradoxo ético no qual a experiência do pecado remete ao "retorno" a um arrependimento. Nisso existe uma transição fenomenológica da mancha para o pecado. Também nesse momento abordaremos a confissão que oferece uma saída à emoção e se projeta na culpabilidade, nas noções perante mim e do perante Deus.

A reflexão anterior nos conduzirá ao um terceiro momento, no qual abordaremos o desejo de justificação do homem que procede da experiência do homem de servidão.

Em um quarto momento, tentaremos mostrar como Ricoeur aponta o mal dentro de uma totalidade de sentido. Teremos de explorar o mito adâmico no sentido que a confissão dos pecados nos conduz a uma convergência do mito adâmico com a cristologia.

No quinto momento abordaremos como o mito adâmico explora o ponto de ruptura entre a ontologia e a história. Ao homem é atribuída a responsabilidade do mal que ele "começa" no sentido de uma criação. E no sexto buscaremos mostrar se existe um deus mau dentro de uma visão trágica da existência. 
Através desses momentos encontraremos a esperança a que Ricoeur se refere em seus textos.

\subsection{O problema do Mal}

\subsubsection{Existe uma conciliação entre o mal e a liberdade?}

Quando falarmos sobre o mal, poderíamos supor que Ricoeur faça uma teologia ou algo dogmático em relação a esse tema, mas o que ele faz é uma fenomenologia-hermenêutica.

A fenomenologia é, por assim dizer, o primeiro segmento da compreensão filosófica, pois a fenomenologia não pode realizar o seu programa de constituição sem constitui-se em uma interpretação da vida do eu. A fenomenologia, não acende ao plano da realidade em sua plenitude, não acende ao mundo da vida, ao qual a compreensão é o seu objetivo e a sua posição a sua pressuposição.

Entre uma fenomenologia e a hermenêutica existe uma diferença entre a realidade e a possibilidade. A questão do mal representa para a filosofia, um campo injustificável, da injustificabilidade do mal é a pedra de tropeço, a qual não pode ser afrontada diretamente, se não se destrói a mesma como um pseudo-conhecimento ou o mal como mal. O único caminho praticável é o da fenomenologia dos mitos do mal ou uma mítica do mal, na qual a culpa e a sofrimento venham reconhecidos e não redutíveis como finitude e negação.

O problema do mal suscita em Ricoeur uma questão mais vasta, uma interpretação filosófica do mito e do símbolo, ou seja, uma relação entre simbólica do mal e fenomenologia da vontade; entre eidética e empírica; entre reflexão e mundo. A filosofia não é um início absoluto, mas uma dúvida, uma interrogação sobre um saber no qual e a partir do qual essa se interroga e da qual duvida. Por isso a filosofia é reflexão. A filosofia de Ricoeur, em especial na Simbólica do Mal, provoca um progresso no pensamento, fundando uma relação circular que se instaura entre fenomenologia e simbólica. De um lado, a criticidade da reflexão fornece o espaço para o realismo da experiência, pois realça a possibilidade aparecer e evidenciar que existe um caráter simbólico, de ambiguidade irredutível, que pode ser recuperada pela reflexão. Com a devida 
análise a reflexão procura justificar o conhecimento prático, sem ser capaz de se adequar, mas recuperando o verdadeiro sentido.

De outra maneira, o realismo da experiência enriquece a reflexão, pois a realidade, em seu mostrar-se, demanda outra reflexão, ou seja, o mal faz parte de uma evidência não recuperável e não alcançável da reflexão.

Podemos mesmo dizer que o tema do mal é introduzido dentro de um plano hermenêutico, através da linguagem escrita (os textos) que amplificam a sua plenificação. Por um lado, os símbolos tem sua pluvivocidade em contextos amplos, a escala de um texto; por outro, o conflito das interpretações se mostram de maneira análoga em textos, e o passo que vai do símbolo aos textos, se restringe à extensão e não tem a mesma intensidade. Uma dialética desse conflito se desenvolve entre o explicar e o compreender. A interpretação é a mescla de uma fase de explicação e outra de compreensão. Explicar é compreender melhor. A compreensão precede, acompanha e envolve a compreensão; a explicação desenvolve a compreensão analiticamente, ou seja, a hermenêutica dos textos sobre o mal conduz a uma interpretação do sujeito que interpreta e sua vinculação ao ser, ao fundo ontológico em que se escreve e daquilo que espera de um ponto de vista escatológico. A constatação de minha finitude me conduz a notar que a esperança é o único meio de superar essa finitude. A esperança é a raiz do consentimento. Mas esse consentimento se faz à luz de uma liberdade de minha pessoa.

O Filósofo francês, nos oferece uma advertência ao nos acercarmos do problema do mal à luz da liberdade, pois

tentar compreender o mal à luz da liberdade é uma decisão arriscada e importante: é decidir-se a entrar no problema do mal pela porta estreita, considerando o mal desde o princípio como algo "humano, demasiado humano"(...) Essa decisão não afeta de modo algum a origem radical do mal, senão a descrição e localização do ponto em que se manifesta o mal... Ainda no caso de que o mal estivesse já incrustado na gênese radical das coisas, sempre será certo que unicamente se nos manifesta pelo modo como afeta a existência humana (RICOEUR, 1960, p. 14). 
Refletir sobre a liberdade é voltar o pensamento para as condições em que essa se realiza. $\mathrm{O}$ ser livre do homem segue o seu livre agir, ou seja, a liberdade vem ao homem exercida em todas as expressões de sua vida.

Falar da liberdade significa, assim, abordar o agir humano, pois uma ação é reconhecida como livre quando ela pode ser responsável perante outros e diante de si mesmo. O senso de responsabilidade, que o homem tem diante de sua ação, revela a liberdade humana, pois não seria uma ação de que o homem se sente responsável se ele não fosse livre. A capacidade física e psicológica de que o homem é dotado é o suporte essencial para a posição dos atos que são significativos. $\mathrm{O}$ homem deve assumir a responsabilidade moral pelos atos cometidos, que é proporcional ao grau de liberdade que desfrutava quando os cometeu.

Uma visão ética do mundo, ou seja, "o esforço por compreender cada vez mais intimamente a liberdade e o mal à luz recíproca com que se esclarecem mutuamente" (RICOEUR, 1960, p. 14), que pretenda dar conta da presença do mal no mundo se cruza com a liberdade. Pois, "uma liberdade que se faça a cargo do mal tem uma via aberta a uma compreensão de si mesma excepcionalmente plena de sentido" (RICOEUR, 1960, p. 14). É pela liberdade que o homem é capaz de projetar o futuro das ações que pretende cumprir. É também pela liberdade que o homem é capaz de examinar seu passado e rever as ações, mesmo aquelas que não desejaria colocar, pois denunciam o mau uso que fez da liberdade. Essa visão ética do mundo encontra limite na liberdade humana pelo fato de não ser absoluta.

(Essa) visão ética não somente é certo que a razão do mal radica na liberdade, senão que, ademais, a confissão do mal é a condição da consciência da liberdade, já que é nessa confissão que podemos surpreender a sutil articulação do passado com o futuro, do si com seus atos, do não-ser com a ação pura no coração mesmo da liberdade (RICOEUR, 1960, p. 25).

Nessa liberdade limitada, o homem não é, absolutamente, responsável pelo mal cometido. Com efeito, o mal entra no mundo quando o homem o põe, mas o homem somente o põe na medida em que cede ao assédio do Ad- 
versário. Aí está a limitação da visão ética e do mundo: no colocar o mal no mundo, a liberdade se torna vítima de outro. $\mathrm{O}$ espaço da manifestação do mal surge quando há o reconhecimento do mal, quando o aceitamos livremente. $\mathrm{O}$ mal que cometo, dentro de uma análise narrativa dos textos Bíblicos, provoca um sofrimento, um mal sofrido, uma punição. Esse mal sofrido pode ter sido praticado consciente, inconscientemente ou mesmo pelos antepassados. $\mathrm{Ou}$ seja, o mal que comento é uma replicação de outro ou em outro, pode ser sofrido por outro, de maneira que o homem se torna vítima do próprio homem.

A visão ética do mundo é limitada, pois não é possível atribuir todo mal, como raiz, ao homem. Ele ao pôr o mal, a liberdade se torna vítima de um Outro. O mal, assim, é um desafio, porque é sempre escandaloso, mostra-se sempre com uma lógica mais complexa que a que estamos habituados. Ao mesmo tempo que ele resiste a uma harmonização conceitual, estimula o pensamento sobre o agir humano perante o mal e o sentindo dessa realidade. Por isso é que o mal é injustificável.

A partir de uma visão ética do mundo que reconhece seu limite, é possível pensar em uma inteligência da liberdade. Essa visão ética, mesmo em seu limite, sublinha a estreita relação entre o mal e a liberdade. $O$ homem tomando sobre si a carga do mal, por sua responsabilidade, faz com que a liberdade se eleve a uma compreensão de si cheia de significado.

Desta forma, em uma visão ética, não somente verdadeiro afirmar que a liberdade seja a razão do mal, mas que a confissão do mal é a condição da consciência da liberdade, pois é nessa confissão que podemos entrever a sútil articulação do passado e do futuro, do eu e dos atos, do não-ser e da ação pura no coração mesmo da liberdade. Essa é a grandeza que representa a visão ética do mundo (RICOEUR, 1960, p. 16).

Existe, assim, uma contraposição entre a ética e a antropologia que somente pode ser resolvida através do problema do mal.

A visão ética do mal faz da existência da culpa o seu ponto de partida. Um exemplo clássico é a análise kantiana que parte da visão de um mundo decaído e do homem dividido em si-mesmo. Ela radicaliza e transfere tal visão a uma antropologia que falha em encontrar o espaço para colocar-se como 
diferença. Segundo Ricoeur, a análise kantiana "procede de uma antropologia pessimista dominada pela teoria do mal radical. Assim, o mal no homem vem radicado na sensibilidade, separada da razão. Ricoeur mostra que Kant não explora todas as possibilidades originárias do mal, mas dá uma descrição do homem na perspectiva da paixão e no dualismo ético.

Ricoeur está convicto que ao se acercar do problema do mal pela liberdade não faz algo arbitrário, pois parece a via mais ajustada e apropriada à natureza do problema. De fato, "o espaço da manifestação do mal só aparece quando ele é reconhecido, e ele somente é reconhecido na medida em que é aceito por uma escolha deliberada" (KANT, 1974, p. 79).

Tanto na Simbólica do Mal e como no Conflito das Interpretações, Ricoeur mostra que não é na introspecção psicológica do sentimento da falta, mas símbolos e nos textos sacros que nos é oferecido o ponto de partida a respeito do mal. Esses textos são os da literatura penitencial nos quais as comunidades de crentes exprimiram a declaração do mal. Eles contêm a experiência do mal em sua linguagem e, como tal, documentam e miram a consciência confessante. $\mathrm{Na}$ linguagem simbólica da confissão, a consciência religiosa aborda uma compreensão de si, correspondente à compreensão de seus atos dos quais ela se acusa e que são objetivados nos textos bíblicos. Ricoeur se limita àqueles símbolos e textos que fazem parte da nossa memória cultural.

Os textos têm a capacidade de mediar a consciência de si e o conhecimento de si provendo uma apropriação de sentidos. Na filosofia ricoeuriana têm por função vencer uma distância, um afastamento cultural, de tornar o leitor igual a um texto tornado estranho, e, assim, de incorporar o seu sentido à compreensão presente que um homem pode ter de si mesmo. Dito isso, Ricoeur propõe religar a linguagem simbólica à compreensão de si, pois:

Toda interpretação se propõe a vencer um afastamento, uma distância, entre a época cultural passada à qual pertence o texto e o próprio intérprete. Ao superar essa distância, ao tornar-se contemporâneo do texto, o exegeta pode apropriar-se do sentido: de estranho ele quer torná-lo próprio, isto é, fazê-lo seu; é o engrandecimento da própria compreensão de si mesmo que ele persegue através da compreensão do outro (RICOEUR, 1999, p. 18). 
Ricoeur assinala que as explicações dadas não lançam o homem para fora de si e muito menos satisfazem. A linguagem da razão é limitada e derivada, por isso, defende que as linguagens mais arcaicas possam nos dar uma resposta à questão do mal e da liberdade. Por isso, a filosofia deve seguir o caminho pelas expressões menos elaboradas, mais balbuciantes da confissão do mal. "Uma fenomenologia da confissão é, pois, a descrição das significações, e das intenções significadas, presente numa certa atividade de linguagem: a confissão" (RICOEUR, 1999, p. 416).

Confessar o mal é ligar o homem, não somente com seu lugar de manifestação, mas também como seu autor. A confissão da falta é ao mesmo tempo, descoberta da liberdade. Assim, a confissão implica, fundamentalmente, em uma visão ética de mundo pela qual se compreende um pelo outro, a liberdade e o mal.

\subsubsection{O simbolismo da mancha desperta o olhar ético em nós}

A mancha é o símbolo mais primitivo e obscuro, pois marca a concepção mágica da entrada do mal no mundo. Nela predomina a dimensão objetiva do impuro. É, também, o mais elementar e rico símbolo na linguagem da confissão já que diz tudo em enigma o que a filosofia jamais poderia dizer em razão, à luz natural. A mancha não só tem início com um significado físico. Ela pode ter um significado simbólico, ou seja, ela é a valência ética do temor e da justa punição, concebida como reconstrução e a capacidade de elevar-se ulteriormente a uma ordem hiperética, na qual o temor se identifica com o amor ${ }^{1}$. Essa equivalência simbólica da mancha não é uma imputação de um agente pessoal, mas uma violação objetiva de um interdito que mistura falta e mancha. Assim, a mancha é o esquema primeiro do mal.

A consciência da mancha é indireta. A mancha é um mal diagnosticado. Esse mal é reconhecido a partir da desgraça pela qual o homem é afligido e que, no sistema de puro e impuro, recebe uma punição por causa da ofensa a um deus,

1 “(...)esse temor seja o meio privilegiado através do qual o homem acede a uma ordem diferente, uma ordem como que hiperética onde o temor fosse totalmente confundido com amor (...) a abolição da crença não poderia ser outra coisa senão o horizonte (...) o futuro escatológico da moralidade humana. Antes de banir o temor, o amor transforma-o e o transpõe (...) só o amor perfeito bane o temor." (RICOEUR, 2013c, p. 61) 
infração à justiça que devemos às outras pessoas. Ser punido é sofrer, sofrer uma pena proporcional à falta. A punição suscita "uma esperança de que o próprio temor desapareça da vida da consciência” (RICOEUR, 2013c, p. 205). A abolição do temor da punição somente é compreendida com o alcance de uma consciência ética que vai do medo à esperança da salvação. A esperança pela salvação não é uma ilusão, mas um anseio que desemboca na confissão do mal.

A transgressão de uma "lei divina" dispara automaticamente um gatilho: o homem se declara culpável independente da consciência de seus atos e de suas intenções. É culpável objetivamente em razão de uma violação involuntária, que sobrevém de um lugar puramente hipotético. $\mathrm{O}$ mal sofrido é suficiente para estabelecer a culpa da pessoa pelo qual é afligido. Entre o mal e a desgraça existe uma relação de causalidade, equivalente. $\mathrm{O}$ mal psíquico é sintoma do mal moral. A ordem psíquica constitui a medida da ordem moral, pois a ética determina e condiciona o nosso ser psíquico.

A relação de equivalência é um estado da consciência no qual o mal e a desgraça "não aparecem dissociados, em que a ordem ética do fazer mal [ mal-faire] não se discerne da ordem cósmica e biológica do mal-estar [mal-être]: sofrimento, doença morte, insucesso" (RICOEUR, 2013c, p. 41-61). Desta forma, o ser moral desenvolve psiquicamente seus efeitos.

A mancha é uma coisa qualquer que infecta por contato, independentemente de toda intenção subjetiva e que "opera como uma força no campo de nossa existência, que é inextricavelmente psíquica e corporal" (RICOEUR, 2013c, p. 42). Ela é uma "substância", algo que infecta nosso ser psíquico e corporal. Assim, o mal da mancha, que provém da mancha, tem uma positividade que não resulta do querer humano, pois existe independentemente de todo ato do sujeito. $\mathrm{O}$ homem descobre sua existência através das penas a que é submetido. $\mathrm{O}$ mal sofrido conduz o homem a se acusar de um mal cometido, que muitas vezes é inconsciente. Ao acusar-se desse mal cometido, o homem confessa, expressa, por suas emoções, o que está em seu interior, esperando de alguma maneira que seja perdoado. Esperando, por assim dizer, um evento futuro que o possa remir. O homem ao confessar o mal cometido mostra que a sua "linguagem é a luz da emoção, através da confissão a consciência de culpa 
é trazida à luz da palavra; através da confissão o homem continua a ser palavra mesmo na experiência do seu absurdo, do seu sofrimento, da sua angústia” (RICOEUR, 2013c, p. 24). Isso mostra que o mal afeta, seja ele sofrido ou cometido, a existência humana.

O mal da mancha sinaliza o despertar da consciência e a responsabilidade pessoal que inaugura o momento da confissão de uma falta pessoal, causa presumida de toda desgraça sofrida.

É pelo sofrimento que a mancha educa a consciência para liberdade. A consciência da mancha é uma "consciência terrorista", que causa uma violência psicológica no indivíduo. Ela vive com medo do castigo do interdito. $\mathrm{O}$ transgressor é submetido a uma punição automática e inescrutável destinada a "satisfazer" a ordem violada. Desencadeada pela cólera, pelo extrapolamento da interdição, a mancha vinga a ordem rompida e expia a ofensa.

Para Ricoeur, o mal pelo sofrimento, considerado como uma expiação, enche-se de uma significação ética: "Este mal de sofrimento [mal-pâtir] relaciona-se com o mal da ação [mal-agir] tal como a punição procede inevitavelmente da mancha” (RICOEUR, 1960, p. 192). O sofrimento convida o homem a buscar na sua conduta "moral" a razão de seu mal-estar. Sob o regime da mancha, o homem é acusado e responsável pela sua desgraça no mundo.

Ricoeur explica que existe uma ligação entre a mancha e o sofrimento, e que é vivida em temor e tremor. Essa se mantem com uma tenacidade tanto maior quanto pôde constituir, durante bastante tempo, um esquema de racionalização, um primeiro esboço de causalidade; se sofres, se estás doente, se falhas, se morres, é porque pecastes; "o valor sintomático e detentor do sofrimento em relação à mancha converte-se em valor explicativo e etiológico do mal moral" (RICOEUR, 2013c, p.47).

Para o filósofo francês, essa acusação desperta a consciência para a responsabilidade. Ela está em relação a uma palavra definida e dentro de um ambiente humano, que determina o que sejam ações puras e impuras. Essa palavra serve de instrumento para sair de uma consciência suja. A consciência, esmagada pelo interdito e pelo sofrimento, se interroga sobre a falta-culpável em referência ao repertório de ações socialmente classificadas como impuras. 
A punição justa não abarca tudo o que possa estar implícito na angústia do manchado. Ao existir a exigência de que o homem sofra de forma justa, para Ricoeur, "nós esperamos que essa tristeza tenha não só uma medida, mas um sentido, isto é, um fim" (RICOEUR, 2013c, p. 59).

Note-se que a vingança contra a violação de certa ordem não é destinada a destruir a culpa, mas a reabilitar a ordem violada. Dentro do regime da mancha, o impuro e o puro recuperam a divisão entre o sagrado e o profano. $\mathrm{O}$ sagrado revela o castigo, não somente como negação, mas como afirmação da integridade original através do emendar-se do culpado.

Aquele que crê nesse regime da mancha vive sob a ameaça do castigo, passa, dessa forma, de uma consciência da mancha a uma moralidade. O homem antecipa a punição tomando consciência das consequências de seus atos e se prepara para assumir o castigo como justa punição de uma violação. Esse assumir a punição reduz a culpa e obtém a restauração da ordem do mundo e de si mesmo.

No processo da mancha o homem ignora a distinção entre o voluntário e o involuntário. $\mathrm{O}$ homem não está diante de uma figura pessoal que responde a suas violações, mas diante de um fundo obscuro e sem face que constitui a ameaça perpétua de sua existência e que assume a salvaguarda da ordem do mundo.

Através dos interditos, o indivíduo é convidado a reencontrar a existência de uma ordem que não quer e que procede de um lugar que já está reservado para seu destino. Esta ordem define cada um dos limites que não podem ser transpostos impunemente.

A observância de tabus requer mais que observância. Ela requer que se mantenha o espírito em um estado de vigilância constante, mas também de terror, pois a possiblidade de que a falta não seja eliminada é algo potencial, não por causa das somas dos pecados, mas porque a consciência está "vergada diante da fatalidade do sofrimento vingador" (RICOEUR, 2013c, p. 59).

$\mathrm{Na}$ confissão se manifesta uma liberdade que ascende à consciência de imputabilidade de seus atos. Essa imputabilidade é uma pura objetividade, pois, não se refere à qualificação moral dos atos, nem à intenção subjetiva do autor. Pode-se dizer que ela somente constata a transgressão do interdito e o 
que a constitui é simplesmente a objetividade da transgressão. O sujeito que se imputa é mais um portador de uma sanção do que o autor do mal.

O homem, quando se atribui autor do mal, reconhece e assume as consequências de seus atos. A lei da retribuição desenvolve uma justiça punitiva que estabelece uma relação entre o crime e o castigo. É interessante notar, que para a justiça a consciência do castigo precede a do crime. A consciência de ser autor do ato mal segue a consciência de ser sujeito da sanção. Ao aceitar o sofrimento, como uma pena que já o expia dos atos praticados, o homem se confessa culpado e responsável pelo mal.

Essa responsabilidade mostra que o homem adere completamente à lei da retribuição sem perguntar se sua aplicação é justa, ou seja, se ele rigorosamente é punido e se corretamente se acusa. Se a imputação da sanção revela a responsabilidade humana, o resto é a consciência da mancha que estabelece a medida desta responsabilidade no mal sofrido ou praticado.

A composição indissociável entre o mal do sofrimento e o mal da ação esboça a distinção física e ética em relação ao sofrimento e a imputação da falta, que não tem o poder da violência punitiva. $\mathrm{O}$ mal físico não emana organicamente do mal moral, mas precede o núcleo que ultrapassa a consciência em sua qualidade de garantir a ordem do universo.

Nessa situação, cabem algumas interrogações: o homem é punido justamente? O sofrimento é equivalente aos atos cometidos? Em razão dessas dúvidas, a instância da mancha dá início à existência ética. Ela suscita, por assim dizer, um pensamento interrogativo em relação aos atos praticados e, ainda, conserva a possibilidade de alcançar o movimento de reportar os atos aos motivos desses atos entrando, assim em uma existência verdadeiramente moral.

\subsection{Existe uma incompatibilidade entre o mal e uma ética}

Enquanto a mancha é ligada a algo que infecta, que afeta direta ou indiretamente o corpo, o pecado é associado uma atitude contra Deus, assim, a consciência atinge o nível ético da falta. A palavra pecado no Antigo Testamento se organiza ao redor da imagem central do desvio de conduta. É o inverso do simbolismo da mancha que contamina por contato. 
A transição fenomenológica da mancha para o pecado se realiza graças à personalização do Sagrado, pois é a relação "pessoal com um deus que determina o espaço espiritual no qual o pecado de distingue da mancha" (RICOEUR, 2013c, p. 64).

A transição da mancha para o pecado é nos dada quando "o símbolo da mancha é dominado pelo de 'amarra' que ainda é um símbolo de exterioridade, mas que exprime mais a ocupação, a possessão e a escravidão que o contágio e a contaminação: 'Que o mal e o mal que está no meu corpo, que está nos meus músculos e nos meus tendões desapareça hoje', suplica o penitente; no entanto, ao mesmo em que o esquema da mancha se incorpora no da possessão, as noções de transgressão e de iniquidade são acrescentadas (...) É já na relação pessoal com um deus que determina o espaço espiritual no qual o pecado se distingue da mancha; o penitente experiência o ataque dos demônios como sendo a contrapartida do afastamento do deus (...) o penitente toma consciência do seu pecado enquanto dimensão da sua existência e já não como uma simples realidade que o assombra" (RICOEUR, 2013c, p. 64)

O homem toma consciência do mal como uma dimensão e de sua existência e não mais como uma realidade exterior que o assalta. $O$ pecado é uma grandeza religiosa determinada pela categoria do perante Deus.

Essa categoria do perante Deus tem presente a relação entre um Deus e seu povo: de um lado, encontra-se o amor de Deus, que se comunica, chama, doa-se totalmente, escolhe e faz aliança; de outro lado, encontra-se o afastamento do ser humano, que foge, desconfia, revolta-se, rompe e despreza, estabelecendo-se como rival.

Entre o homem e Deus, a aliança suscita uma relação de apetecimento mútuo. O homem está implicado na iniciativa de Deus. Iniciativa essa que é um prévio de um encontro e diálogo, mas que parece um silêncio de Deus ao homem. Esse encontro e diálogo possui uma característica ontológica e existencial prévia à compreensão moral e especulativa da aliança: "é no seio dessa interação entre vocação e invocação que se desenrola toda a experiência do pecado" (RICOEUR, 2013c, p. 68). 
Ricoeur reconhece que é na experiência judaica do pecado que se conhece a tensão constitutiva da ética da aliança. De um lado está o amor de Deus que chama seu povo para santidade e faz uma aliança; de outro o afastamento do ser humano que rompe com Deus e estabelece-se como rival. Em um sentido escatológico esse afastamento condena o homem à morte. Sob o impulso profético, a aliança produz uma ética essencialmente caracterizada pela dialética da exigência ilimitada e de um imperativo limitado (Cf. ELLUL, 1946, p. 49). O chamado e o pedido interminável à santidade, que o Santo por excelência endereça ao homem, constituem os termos do agir moral, suscitando no homem uma exigência infinita de perfeição e de justiça que a transforma em prescrição detalhada da lei e confere um dinamismo desconhecido à ética da simples observância da lei.

O magistério profético propõe um ideal de perfeição e de justiça que visa à realização da pessoa humana em sua totalidade, além dos atos isolados prescritos pela lei. A “consciência do pecado reflete essa tensão: por um lado, ela aprofunda-se, para lá das faltas, num mal radical que afeta a disposição indivisível do 'coração'; por outro, ela se dispersa em múltiplas infrações denunciadas por um determinado mandamento" (RICOEUR, 2013c, p. 75). Compreender a experiência do pecado é compreender esse ritmo do profetismo e do legalismo (simples observância da lei) no íntimo da aliança e manter viva a sua unidade.

Para manter viva sua unidade existe assim, uma tensão entre a consciência absoluta, mas informe, e por outro lado, a lei finita que esfarela a exigência, pois para o homem não se é justo, nem se é culpado completamente. Ele é justo ou culpado conforme determinações concretas. Ricoeur nos mostra que "a lei é um 'pedagogo' que ajuda o penitente a determinar o seu modo de ser pecador" (RICOEUR, 2013c, p. 75). Assim, ideal de perfeição e de justiça vai além dos atos singulares, o pecado deve ser remetido para muito além de enumeração de faltas, pois o ritmo da exigência indeterminada e dos mandamentos determinam a revelação interiormente radical do pecado como seu contrário, a obediência do seu coração. 
Enquanto a mancha é ligada a um contágio, o pecado é associado a uma aversão a Deus ou a um ir contra Deus. Essa concepção de pecado a categoria do perante Deus na qual existe uma ideia de relação destruída mantem-se implícita, de um afastamento de Deus.

O pecado se opõe à fé. Essa oposição é marcada nos textos bíblicos por uma relação ferida do pecador para com Deus. O simbolismo do pecado exprime, fundamentalmente, a ruptura de uma relação, "a perda de um vínculo, de uma raiz, de um solo ontológico" (RICOEUR, 2013c, p. 87). A imagem principal do desvio em relação à linha reta, o extravio da viagem, ao não transpor, constantemente, concorre para uma ação anormal. Mas essa ação é interpretada com uma desobediência, ela é colocada como uma intenção malvada do homem que toma a iniciativa de opor-se a Deus. A oposição do querer humano à vontade divina situa a origem da ruptura do diálogo e da situação consequente do desvio e da perdição na qual o homem se encontra depois da queda. Assim Ricoeur nota que "a ruptura do diálogo, transformada numa situação, faz do homem um ser estrangeiro ao seu lugar ontológico" (RICOEUR, 2013c, p. 89).

O homem é responsável pelo pecado. Ele se rebela e rompe a sua relação com Deus. Essa iniciativa cria uma existência que se afasta de Deus e é alienante. O pecado quebra o pacto entre Deus e o homem, ele não é uma substância, mas um nada, uma negação do que deveria ser: "é certo que a cultura que não criou a ideia de ser também não tem um conceito de nada; mas pode ter um simbolismo da negatividade: através da falha, do desvio, da rebelião, do extravio" (RICOEUR, 2013c, p. 90).

A negatividade do pecado é marcada, na Bíblia, pelas imagens do sopro e do ídolo. A existência pecadora é como o sopro passageiro; ela é vã, pois é incapaz de salvar aqueles que recorrem aos seus ídolos: A imagem existencial do "vão", do vazio, que muitos percebem dentro de si, vem fundir-se com a imagem do "ídolo" que precede uma reflexão teológica mais elaborada sobre os falsos deuses, os deuses pagãos não valem nada. Nada é a definição do homem que se fia nos ídolos. Essa vaidade dos ídolos descobre o vazio e o não-sentido dessa existência livre pelo absurdo que se revela no abandono do homem por Deus. 
O esquema do "nada" do ídolo e do idólatra é a réplica, do lado do homem, do esquema da "Cólera de Deus"(...) o homem abandonado é a manifestação de Deus na qualidade de Aquele que abandona. O esquecimento de Deus pelo homem reflete-se no esquecimento do homem por Deus; assim Deus já não é o "Sim" da palavra que disse, e assim aconteceu; ele é o "Não" que suprime o malvado, os seus ídolos e toda a sua vaidade (...) talvez o próprio "Não" da interdição, no mito da queda seja uma projeção na esfera da inocência de uma negação emanada do próprio pecado; talvez que toda a ordem da criação (...) seja suportada pela afirmação das oposições e de uma desproporção original: 'Que assim seja”' (RICOEUR, 2013c, p. 93). Podemos ver também Is 49, 7 e Is 49,15 , nesses textos estão implícitos a ideia de conversão.

A experiência do ser abandonado a si mesmo pode conduzir o pecador a negar Deus ou a aderir ao seu plano de salvação. O profeta prega o retorno a Deus. Esse retornar está presente em forma de arrependimento. $\mathrm{Na}$ dureza da sua disposição, o homem pode retornar de sua vida malvada e reintegrar-se na relação primitiva de Aliança com Deus. O profeta parece lembrar que o homem tem a capacidade de operar inteiramente e por si mesmo esse retorno que reconcilia com Deus. Da mesma forma que tem a iniciativa de quebrar a Aliança, tem a iniciativa de restaurá-la. A liberdade que o pecado conserva em seu poder não é somente de fazer o mal, mas de desfazer o seu voto a Deus.

Uma visão ética do mal permite confirmar a responsabilidade total do homem pela existência do mal. Ela orienta em direção que a concepção do mal é uma realidade que depende inteiramente da liberdade, tanto para sua entrada, como pelo seu desaparecimento do mundo. Mas ela não dá conta inteiramente da experiência judaica do pecado.

O fiel que é exortado pelo profeta a retornar, implora o retorno pedindo perdão, pois é na totalidade do perdão-retorno que temos a restauração da Aliança e do sentido total do pecado graças ao paradoxo que ele contém, pois, “o profeta não hesita em exortar ao 'retorno', como se este dependesse inteiramente do homem, e a implorar pelo 'retorno' como se ele dependesse totalmente de Deus" (RICOEUR,2013, p. 93). 
Em vista disso, o aspecto da experiência do pecado nos remete ao paradoxo do "retorno", pois "a Aliança é o símbolo de uma relação quase personalista, o símbolo fundamental do pecado exprime a perda de um vínculo, de uma raiz, de um solo ontológico: a isso corresponde, do lado da redenção, o simbolismo do retorno" (RICOEUR, 2013c, p. 97), e que inclui a fé como "fruto de uma escolha livre da majestade escondida" (RICOEUR,2013c, p. 97) é o arrependimento. Contudo, se arrependimento humano não é capaz de reatar a Aliança e se a consciência do pecador examina a necessidade da intervenção divina, é porque o pecado não se mede pela consciência subjetiva que o homem toma de sua responsabilidade, mas por uma realidade interior, mais objetiva, na qual a medida não é a consciência, mas a vigilância absoluta e Deus.

Para Ricoeur, o realismo do pecado é marca de uma acusação profética. $\mathrm{O}$ profeta denuncia o pecado pela advertência que profere contra o povo e contra seu destino político. Essa acusação suscita no homem um exame de consciência que desabrocha pela confissão dos pecados pessoais e comunitários, pois cada um se descobre pecador, na medida em que é membro de um povo que peca.

A imputação pessoal, dentro de uma teologia da história, carrega o peso de uma hipoteca comunitária. O indivíduo é solidário de uma comunidade de pecadores que afeta e ultrapassa a sua responsabilidade pessoal. Essa relação comunitária cria uma situação na qual o pecador se encontra implicado, não somente pelas causas de suas faltas, mas pelas consequências das faltas de outros. Desta forma, o pecado é tanto individual como comunitário. Ele não pode ser reduzido pela responsabilidade individual, nem medido pela consciência reflexiva; ela resulta da denúncia profética que revela o pecado do povo. Tomando consciência do pecado do povo, o penitente percebe ao mesmo tempo seu próprio pecado e a solidariedade que o liga a outros no mal. Essa tomada de consciência vem graças ao ministério profético que situa o pecado diante da guarda absoluta de Deus.

O realismo do pecado reside no fato que a medida e o critério da falta não são constituídos pela consciência do pecado. Deus, e não o homem, mensura o pecado. Isso porque o pecado é revelado pelo oráculo profético que suscita no homem a tomada de consciência de sua situação objetiva do desvio. 
O pecado é uma situação real, insistente, na qual o homem se descobre como pecador coletivo. Desta forma, o pecado extravasa a subjetividade do indivíduo que está assentada dentro de uma subjetividade coletiva que nenhuma consciência individual consegue assumir totalmente. A imputação coletiva, além de mostrar a solidariedade de todos no mal, produz a confissão simultânea da responsabilidade e da irresponsabilidade individuais pelo mal do qual se acusam e são punidos. A consciência do penitente assume o pecado até certo ponto.

É importante ressaltar que esse é o típico pensamento que o profetismo e os primeiros padres tentaram fazer chegar até nós a concepção de um pecado comunitário no qual o mito adâmico exprime uma unidade hiperbiológica e hiper-histórica do povo no qual o pseudoconceito de pecado hereditário reenvia intencionalmente para um vínculo comunitário admitido na confissão dos pecados.

Esse é o limite da responsabilidade individual que é posto por um aspecto da experiência do mal por aquele mal aparente, não mais como um não-ser redutível ao poder do desvio, da queda que possui a liberdade, mas como uma "natureza", uma "substância" que se apodera da liberdade e a tem cativa. Essa imagem do mal, a Bíblia exprime pela imagem de possessão. O pecado domina a liberdade, ou ainda, a liberdade é possuída, enfeitiçada pelo pecado. Essa é a visão ética que caracteriza a Bỉblia, o mal não é uma substância difusa e exterior, nem uma figura demoníaca personificada. Ele é, certamente, uma natureza que a liberdade contrai e que forma a unidade da espécie humana no pecado. Sendo interior e objetivo, o pecado é uma força que se apodera do homem e o liga ao seu poder.

O pecador vive sob a posse do mal que o aliena e altera a origem do seu querer e do seu agir. Seu poder de fazer o mal é cercado de uma impotência, uma paralisia pelo poder do mal radical que envolve a liberdade na origem de sua difusão e a torna indisponível. O simbolismo do pecado aponta uma relação entre o mal radical e o próprio homem, entre uma destinação originária do homem. Esse simbolismo do pecado nos diz que por mais positivo e sedutor que seja, ele nunca poderia fazer do homem um nada, não poderia mudar a disposição e as funções da humanidade do homem. 
O mal radical reduz o homem à sua impotência e à servidão do pecado. Pelo pecado, a liberdade é reduzida à escravidão. Assim para Ricoeur, "a problemática fundamental da existência não será tanto a da liberdade, entendida no sentido de uma escolha a tomar em face de uma alternativa radical, como a da libertação; o homem cativo do pecado é um homem a libertar, todas as nossas ideias de salvação, de redenção, procedem dessa cifra inicial” (RICOEUR,2013c, p. 110). Esta experiência do cativeiro compreende uma experiência da própria impotência do homem perante a sua liberdade de escolha.

O chamado ao retorno a Deus é iniciado no interior de uma súplica pelo perdão divino. Esse perdão é que opera o retorno do homem para Deus. Porém, resta que o homem guarda um poder suspensivo de sua escolha. $\mathrm{O}$ simbolismo do retorno e do perdão, considerando na sua terra natal, "mantém suspensas todas as aporias da teologia respeitante à graça e à vontade, à predestinação, e à liberdade" (RICOEUR, 2013c, p. 98).

O perdão é o "arrepender-se" de Deus que toma a iniciativa, não mais de uma condenação do homem, mas de uma nova relação de Aliança. O homem, pois, vive dentro de um cativeiro, o perdão é um resgate, uma libertação.

A liberdade, educada pelo interpelar profético, compreende-se, na instância do pecado, responsável pela existência do mal. O mal, obra da liberdade, é um não-ser. Ele é posto para a liberdade, essa rompe com Deus e rejeita seu destino original. Esse mal cria uma situação pessoal e comunitária na qual a liberdade vive prisioneira de sua obra.

Para lá das transgressões isoladas, existe um mal fundamental, há uma raiz do poder da liberdade, que constitui uma espécie de natureza má contraída pela liberdade, em consequência de sua escolha má que afeta a liberdade e torna ineficaz todo desejo de emendar-se. O pecado, uma vez cometido, altera o poder da liberdade e exerce sobre o homem uma aderência, que o torna incapaz de afastar-se dele. A consciência da impotência apaga o mal e suscita no homem o desejo de justificação.

Essa nova instância da experiência da falta, a culpabilidade, apontará para uma resposta sobre: Por que o perdão ultrapassa o círculo ético do esforço humano de conversão? É realmente impossível ao homem desligar sua existência pessoal e comunitária dos grilhões do pecado pelo qual está cercado? Além disso, essa instância permitirá compreender o paradoxo ético, ou seja, a afirma- 
ção simultânea da responsabilidade total e da impotência radical do homem em relação ao mal. Contudo, quando o símbolo do cativeiro torna-se símbolo do indivíduo culpado, "o cativeiro desliga-se da reminiscência histórica e adquire uma qualidade de símbolo puro: a cifra designa um acontecimento de liberdade" e esse acontecimento é o da esperança, que se movimenta rumo a um evento futuro, a Ressurreição.

\subsubsection{A desesperança ético-religiosa}

A compreensão de Ricoeur sobre a queda do ser humano perante Deus traz consigo a ideia de confissão como já foi visto. $\mathrm{O}$ mito da queda remete a uma confissão dos pecados. A confissão oferece saída e expressão à emoção, projetando para fora do ser humano emoções inerentes à consciência humana de culpabilidade. Pois,

A experiência que é confessada pelo penitente é uma experiência cega: permanece presa no invólucro da emoção, do medo, da angústia, é esta nota emocional que suscita a objetivação num discurso: a confissão exprime, empurra para o exterior a emoção que, sem ela se fecharia sobre si mesma, como uma impressão da alma; a linguagem é a luz da emoção: através da confissão a consciência de culpa é trazida à luz da palavra; através da confissão o homem continua a ser palavra mesmo na experiência do seu absurdo, do seu sofrimento, da sua angústia (RICOEUR, 2013b, p. 23-24).

A culpabilidade é um momento subjetivo da falta, é a instância do estar perante mim. Ela surge das profundezas da consciência e toma o lugar do perante Deus. A consciência se torna a medida do pecado. Conforme Ricoeur: "A instância da culpabilidade é, portanto, a possibilidade do primado do 'homem como medida' em detrimento do 'olhar de Deus"' (RICOEUR, 2013a, p. 125). A culpabilidade, assim, se caracteriza pela interiorização e a subjetivação da falta ${ }^{2}$, ou seja, sou o sujeito do castigo, mas não o autor do mal, respondo pelas consequências de um ato.

2 Nota-se que para Ricoeur a consciência do pecado se tornará o critério e a medida da falta; o sentimento de culpabilidade coincidirá exatamente com a consciência que o culpado tem de si mesmo e não se distinguirá do "para si” da falta. Contudo, culpabilidade não é sinônimo de falta. 
A culpabilidade designa o momento subjetivo da falta, tal como o pecado é o seu momento ontológico; o pecado designa a situação real do homem perante Deus, seja qual for a consciência que ele tenha dela; essa situação deve ser descoberta, no sentido próprio do termo: o Profeta é esse homem capaz de anunciar ao Rei que o seu poder é fraco e vão. A culpabilidade é a tomada de consciência dessa situação real e, se é que podemos nos expressar assim, o "para si” dessa espécie de "em si” (RICOEUR, 2013c, p. 118).

A culpabilidade exprime a maneira consciente pela qual o homem se sente afetado pela falta, ela se organiza em torno da imagem do peso. O pecado tem por imagem o desvio, a culpabilidade tem o peso. Ao invés do perante Deus, o sentimento de culpabilidade ressalta o sou que quem, interiorizando, desta forma, o sentimento de culpabilidade pessoal. O medo antecipa o surgimento do peso da ameaça, como o castigo faz calcular o peso da pena sobre a consciência posta em estado de busca de seu crime.

Existe uma diferença fundamental que separa a mancha da culpabilidade: o peso é na mancha a consequência do castigo sofrido e infligido por causa da transgressão de um interdito. Já na instância da culpabilidade, a culpa provém da consciência de ser autor de atos repreensíveis.

O peso designa, dentro da culpabilidade, o mau uso da liberdade, sente como uma diminuição do valor de si. Assim, esse sentimento é, anterior à punição, de diminuição de seu próprio valor que denomina o castigo como restabelecimento e emenda. A culpabilidade revoluciona o sentido do castigo. Conforme Ricoeur: "a culpabilidade inicialmente gera a consciência de castigo, revoluciona essa consciência de castigo e inverte-lhe completamente o sentido; é a culpabilidade que exige que o próprio castigo, enquanto expiação vingativa, transforme-se em expiação educativa. Numa palavra, em emenda" (RICOEUR, 2013c, p. 119). A expiação de uma pena que provém de uma fatalidade está diante de uma vontade refletida que aceita sofrer uma pena corretiva e educativa.

Para Ricoeur, a consciência de ser responsável pelos seus atos nasce quando o homem se encontra em face de um Deus pessoal que exige um ideal de perfeição que ultrapassa todas enumerações de deveres e virtudes. Segundo Ricoeur, "o tu interpelado torna-se o si que se acusa a si mesmo" (RICOEUR, 
2013c, p. 118). Nesse sentido, nasce o homem que se encontra em face de um Deus pessoal que endereça uma exigência infinita de perfeição, excedendo todas enumerações de deveres e virtudes. $\mathrm{O} t i$, com que o profeta faz chegar o pedido para santidade, descobre nele, como um vis-à-vis desta exigência, a profundidade de uma existência possível que é ilimitada para além dos atos múltiplos e das causas, além mesmo de todas possibilidades que ela esconde e que é a capacidade de dar à sua vida uma orientação fundamental, que resulta de uma escolha pessoal e radical em prol, ou contra Deus.

O chamado profético a uma escolha radical esconde no homem a capacidade de "(...) abarcar sua vida inteira e de a considerar como um destino indivisível suspendido por uma alternativa simples" (RICOEUR, 2013c, p. 120). $\mathrm{Na}$ consciência do pecado, esse $e u$ radical tem por parceiro o Deus santo. É por esta razão que a confissão do pecado contém um eu que confessa seu pecado perante Deus. O ministério profético, que profetisa contra o pecado, revela o homem a ele mesmo diante do olhar indignado e acusador de Deus. Esse olhar, que transpassa a exigência infinita de santidade de um código de prescrições detalhadas, penetra profundamente o coração do homem para suscitar nele a consciência da profundidade do enraizamento do mal.

O "olhar de Deus", perante Deus, insere-se na subjetividade humana como uma tarefa de nos conhecermos melhor. Ele constitui a verdade e a manifestação da verdade da situação do homem, de uma dimensão escatológica. Diante desse olhar, o homem toma consciência do contra ti da confissão e do fui eu que... da confissão. O homem se acusa do mau uso de sua liberdade contra Aquele que o coloca diante da vida ou da morte. O pecado torna-se a situação de perdição na qual o pecador se encontra por sua revolta. Essa é a situação que faz do homem estrangeiro, perdido, extraviado, ao seu lugar ontológico por causa da sua rebelião. Dessa forma, a tomada de consciência do pecado não é somente uma situação real perante Deus, mas é uma situação, resultante de uma escolha, que o homem compreende como o fui eu quem... da confissão. A culpabilidade é a acentuação dessa consciência de um eu responsável que pode ir até o esquecimento do perante Deus da consciência do pecado. A falta não é mais 
considerada como uma grandeza religiosa como na consciência do pecado. Ela torna-se uma simples grandeza antropológica.

Pensar a falibilidade, antropologicamente, não reflete o homem diante da antropologia de Platão, Pascal e Kierkegaard, mas reflete o pathos (sofrimento) do homem, ou seja, pensar através de uma reflexão que não tenha origem diretamente do $e$, mas do objeto que está diante do $e u$. Dessa forma, o homem pode ter condições de possibilidade. Ele, assim, envereda por uma ontologia filosófica, falando da patética da miséria, para não cair em uma ontologia absurda do ser e do nada (Cf. CLAVEL, 1998, pp. 18-29).

Dizer que a falta se torna uma grandeza antropológica é, em primeiro lugar, sublinhar a característica individual da imputação. A concepção do mal que, de acordo com o esquema do pecado, é uma situação na qual a humanidade é capturada em um coletivo-singular, sucede ao esquema da culpabilidade, que retoma o mal como um ato que cada indivíduo começa. Na individuação, a imputação rompe com a comunhão dos pecadores que caracteriza a consciência do pecado e que aceita como legítimo a solidariedade de todos diante da falta e da sanção. Assim, a consciência do pecado não tem dificuldade em admitir que pode ser punida pelas faltas que não cometeu pessoalmente por causa da coletividade da pena.

A relação comunitária da falta subsiste ao considerar o indivíduo como membro de uma comunidade que partilha o destino histórico. O homem não tem nenhum problema em acolher a ideia na qual cada um expia a falta de outros em razão da solidariedade e do apetecimento que o liga à sua relação comunitária. Ricoeur nota que quando o pensamento comunitário da falta desaparece e desenvolve-se a solidariedade, o indivíduo toma consciência do absurdo de sua punição por crimes que ele não cometeu e que não é de seu interesse. Quando o indivíduo se torna solitário deixa de ser solidário. Ele entra no mundo de uma culpabilidade isolada e somente pode lhe imputar a falta que ele mesmo cometeu. Desta maneira, a consciência da culpabilidade ascende à responsabilidade e à retribuição pessoal. Sua máxima, assim, não é mais “os pais comeram uvas verdes e os dentes dos filhos se embotaram!" (Jr 31, 29), mas será "quem pecar, morrerá”(Ez 18, 3). 
Quando o individualismo emerge rompe a cadeia de gerações como de atos pessoais. $\mathrm{O}$ indivíduo responde somente pelos seus atos, sem se preocupar com a hipoteca social que pode advir dos efeitos dos seus atos sobre os outros. Os atos, não considerados em suas consequências, são revogáveis ao capricho da vontade que os coloca. Deste modo, "rompe-se a lei da dívida secular; cada um paga pelas suas falhas; cada um pode a cada momento recomeçar, 'voltar ao eterno"' (RICOEUR, 2013c, p. 123).

Existe dessa forma uma ruptura da "comunhão dos pecadores" e de uma continuação da estância do perante Deus que acaba por moralizar a falta e a reduzir inteiramente o realismo do pecado. Para a consciência culpada, o mal não é uma situação na qual a humanidade se encontra tomada, ele é um ato que cada indivíduo põe e começa, cada um faz o mal. Ato de um sujeito individual, o mal é um não-ser absoluto, inteiramente redutível à liberdade e perfeitamente explicado por ela. Por isso que, "a culpabilidade implica aquilo que podemos chamar juízo de imputação pessoal do mal: essa individualização da culpabilidade rompe com o 'nós' da confissão dos pecados" (RICOEUR, 2013, p. 122).

A culpabilidade é, como diz Ricoeur, phénomeniste, ou seja, por ela a falta é medida pela consciência individual e que dela depende. Ela é proporcional ao grau de consciência que temos da falta. Essa proporcionalidade da falta depende de sua consciência. Pois "a consciência culpada confessa que a sua falta aceita o maios e o menos, tem graus de gravidade; ora se a culpabilidade tem graus, também tem extremos, os quais são designados pelos dois polos opostos do 'pecado' e do 'justo"' (RICOEUR, 2013c, p. 123). Ao contrário da experiência coletiva e igualitária do pecado, a experiência da culpabilidade é individual e gradual. A culpabilidade tem degraus e se escalona entre dois extremos: o mau e o justo. Desta maneira, "a própria justiça será uma justiça relativa, já não determinada em relação a uma perfeição ilimitada e fora do alcance, mas em relação a uma otimização da justiça presente na figura do 'justo"' (RICOEUR, 2013c, p. 124).

A individuação e a graduação são os dois traços da culpabilidade que confirmam a redução da falta à subjetividade. Esses dois pontos fazem que haja uma perda da dimensão teleológica e comunitária do pecado e conduza o indivíduo a um subjetivismo forçado. Este é o triunfo da visão ética do mundo 
para a qual o mal é inteiramente obra da liberdade. Nessa concepção, o indivíduo tem o poder de escolher entre o bem e o mal. Ele mantém sempre intacto o poder de se livrar do mal, pois o que está por baixo da visão ética do mundo é a ideia de uma liberdade responsável e sempre disponível para si mesma. Entretanto, o homem tem o poder de "apagar" sua falta? Ele pode, em termos paulinos, justificar-se por suas obras?

O tentar justificar-se traz consigo a ideia de escrúpulo que "caracteriza como sendo um regime geral de heteronomia consequente e consentida" (RICOEUR, 2013c, p. 143-144), ou seja, colocar Deus como fundamento moral e religioso da relação. A figura histórica na qual é visível o escrúpulo é o farisaísmo. O farisaísmo evidencia a dimensão do escrúpulo, porque toda vida religiosa, era regrada segundo as prescrições farisaicas. Compreendido a partir de seu momento histórico, o escrúpulo aparece como consequência coerente de um caractere histórico do monoteísmo ético de Israel conforme a orientação essencialmente prática que o farisaísmo imprime à Aliança.

O éthos do povo judeu é ligado à Lei Mosaica que é um acontecimento de consciência histórica daquele povo. A partir desse éthos, Israel tomou consciência de sua eleição e de seu destino singular que o torna à parte de outros povos, pois "o sinal distintivo de Israel entre os povos, é o fato de ter a Lei, esta lei” (RICOEUR, 2013c, p. 136). Essa lei procede de uma estrutura inevitavelmente contingente. Ela é uma prescrição divina que teve ligação com um acontecimento do passado: a transmissão da Lei. Esse acontecimento revelou de maneira completa e definitiva a vontade de Deus e, consequentemente, o sentido da vida humana.

De posse do sentido de sua existência revelada, uma vez por todas, a consciência do escrúpulo não tem mais outra escolha a realizar em sua vida concreta. A vocação do povo de Israel consistia, então, na obediência à Lei que continha a vontade de Deus. É essa vontade de obedecer à prescrição divina em todas as coisas que define a heteronomia consequente e consentida da consciência do escrúpulo.

Sem dúvida, pode-se deplorar que o farisaísmo aumentou o aspecto mosaico da Aliança. Esse agigantamento confina a relação Deus/homem a 
uma instrução concernente ao fazer o que está escrito na Lei no contexto de voluntarismo. Entretanto, reconhecer a grandeza dessa experiência ético-religiosa do farisaísmo, que consiste em ir além da heteronomia vivida em uma obediência integral, manifesta aquela abdicação de livre escolha à suprema afirmação do querer. Desta maneira, o abandono feliz do querer assinala essa heteronomia, que afasta do ser alienante e satisfaz o homem que busca sua bondade em fazer integralmente o que diz a instrução divina. A consciência escrupulosa “(...) é dependente, mas não alienada; isto porque não está 'fora de si', mas 'em casa', uma vez que a sua heteronomia seja consequente e consentida” (RICOEUR, 2013c, p. 145).

De uma parte, a vontade divina foi revelada em um acontecimento passado, de outra parte, ela deve ser cumprida em todos os detalhes da vida presente sobretudo, na esperança futura de salvação. Assim, a consciência do pecado vive interpretando constantemente a lei, a fim de saber se é justa, conforme a vontade de Deus, em determinada circunstância.

A vontade de cumprir a Lei em todos os setores e em todos os detalhes produz um sentido legalista que define e legisla esse fazer em cada situação. A vida moral se transforma em percurso de observância dos preceitos múltiplos e sedimentados, sustentados por um rito que garante a sua exatidão.

Sem sobrestimar os perigos que o processo de regulamentação jurídica e de ritualização da vida moral, que é mudada pela simples observância do preceito, deve-se reconhecer que a consciência escrupulosa leva a culpabilidade a um paradoxo. $\mathrm{O}$ escrúpulo aguça ao extremo os dois traços da culpabilidade: a imputação pessoal e a polaridade do justo e do mau. $O$ fariseu tem uma religião prática, assim, sua ética é dominada pela observância da Lei de Moisés. Essa praticidade constitui o critério objetivo da imputação pessoal e do grau de culpabilidade de cada um. Logo, na observância ou não da Lei o homem é justo ou injusto, a justiça ou a impiedade variam de acordo com a intensidade da observação da Lei.

Os fariseus "fizeram do cumprimento da Lei já não um limite ideal, mas um verdadeiro projeto de vida; o máximo impossível de perfeição é o fundo sobre o qual se destaca o ponto alcançável da justiça: não é pedido ao homem nada que 
ele não possa fazer" (RICOEUR, 2013c, p. 125). A noção de mérito é "a marca distintiva do ato justo é, diríamos, uma afecção da boa vontade; é o aumento de valor do homem, proveniente do valor dos seus atos" (RICOEUR, 2013c, p. 126).

O mérito se liga a uma ideia de recompensa, recompensa pelo mérito. É a justiça de Deus para aquele homem que obedeceu obrigatoriamente à lei. Assim, o mérito é determinado, não mais por Deus, mas pelo homem que observou os preceitos. Esse homem se nega a declarar-se justo diante de Deus. Para tanto, exige uma recompensa pelas suas obras. Praticar a Lei garante a justificação e dá a justa recompensa.

A visão ética da consciência escrupulosa ignora o mal radical, pois o homem não é somente justificado pelas suas obras, mas pode voltar do seu desvio e tomar a via justa. Para essa visão,

o arrependimento significa que o retorno do livre arbítrio a Deus depende sempre dos homens; o exemplo dos grandes ímpios que 'voltaram' para o Senhor está lá para atestar que é sempre possivel que o homem 'mude seu caminho'. Essa ênfase colocada no arrependimento está em conformidade com a interpretação da 'inclinação má como ocasião de pecado e não como mal radical" (RICOEUR, 2013c, p. 148).

Quando o homem retorna a Deus é porque houve o perdão de suas faltas. Todo perdão depende da bondade de Deus. Entretanto, surge uma pergunta: a justificação pelas obras da lei é capaz de purificar o homem de seus pecados? Apenas uma resposta cabe nesse momento. É na experiência paulina da lei que se pode ver a desesperança do homem. O desespero que nasce do pecado é pecado e consiste em atraiçoar o infinito em uma existência fantástica, sem vínculo ou dever, ou trair o infinito por uma existência filisteia.

Paulo mostra que sem a fé em Cristo, à luz da inteligência, o homem não é capaz de se justificar pela lei. Somente será justificado se observar todos os preceitos que são infinitos. Ora, o homem não é capaz de cumprir todas as prescrições da lei. Assim, ele não é mais que um refém da maldição da lei.

A lei oferece a possiblidade de uma justiça aproximada. Para Ricoeur "a própria lei transforma essa aproximação em distância; a grande descoberta de Paulo é que a própria lei é fonte de pecado" (RICOEUR, 2013c, p. 157). 
Paulo desenvolve, na Carta aos Romanos, um problema entre judaísmo e cristianismo, ou seja, uma relação entre pecado, lei e morte. Entre o pecado e a lei há uma ligação, um movimento que desemboca na graça divina pela qual o homem é libertado. $\mathrm{O}$ apóstolo Paulo não põe uma equivalência entre lei e pecado, mas uma relação instrumental que transforma a existência sob o julgo da lei em uma existência necessariamente pecadora. A Lei não é pecado, como diria Paulo, entretanto, é ocasião e instrumento. Ou melhor, essa Lei vem fazer com que o pecador tome consciência de sua falta. A falta como pecado conduz à morte. Logo, a lei que deveria mostrar o caminho seguro para a vida reta se transforma em instrumento de morte. Quem causa a morte não é, todavia, a Lei, mas o pecado que a utiliza.

Paulo ainda afirma que a lei não está somente a serviço do pecado, mas é impotência diante desse. Essa impotência corrompe toda pretensão de querer ser salvo pela lei. Se o pecado exerce sobre o homem um domínio, digamos, superior à Lei, toda tentativa de reduzir a força do pecado pela fraqueza da lei está condenada ao fracasso.

Há um antagonismo entre a vontade e a ação refletida que separa o $e u$ de razão e o eu de carne. O eu de razão aprova pela razão a exigência da lei. Todavia, a ação do homem revela um eu de carne que o eu de razão desaprova. $\mathrm{O}$ eu, portanto, não reconhece mais seu agir e tenta atribuí-lo a um outro.

O homem acredita que não faz o mal, mas que outro o faz em seu lugar. Esse outro que o homem tenta colocar a sua responsabilidade é exterior, mas, ao mesmo tempo, reside no homem. A carne é a habitação do pecado no homem, ou seja, o "eu alienado no seu conjunto, por oposição aos 'desejos do Espírito', constitui o homem interior; a cisão entre mim e mim mesmo, e a projeção para o exterior deste eu alienado de si mesmo, é a chave do conceito paulino de carne" (RICOEUR, 2013c, p. 310).

Esse mal que se manifesta na carne é o resultado da existência humana que é integramente carnal e que a lei não é útil, pois o querer da lei é ineficaz. Por ser uma lei que não pode ser cumprida em sua integralidade, ela é incapaz de justificar. 
A lei, assim, exerce um ministério de condenação. Ela testemunha contra a boa vontade transformando-a em inoperante e mostrando sua miséria. A vontade, desta forma, é cercada por uma vontade que é incapaz de libertar-se e que torna impossível o cumprimento da lei e de sua justiça.

O cumprimento da lei não é um poder do homem, mais que uma simples boa vontade, pois é inconcebível que o homem espere assegurar seu valor diante de Deus pela aplicação impossível da lei. Querer ter a vida pela lei e viver de sua própria justiça é abusar da lei e atribuir-se um papel que não lhe é conferido. Não é caráter dá lei dar instruções e condições de o homem entrar em comunhão com Deus. Essa comunhão é assegurada pela promessa feita a Abraão que é anterior à lei e que a lei não pode anular. É somente da fé na promessa de Deus que o homem recebe a vida.

Toda relação do homem com Deus é baseada na gratuidade da promessa e sob a fé nessa promessa. A lei não é dada para indicar acesso a Deus diferente daquele que a promessa indica à fé. Ela prepara para receber o Evangelho mediante a fé em Cristo.

No contexto do fracasso da justiça pelas obras, a impossibilidade de cumprir a lei, prepara para acolher a justiça da fé. A consciência do escrúpulo não reconhece somente o Evangelho, mas a lei de Deus e sua função pedagógica. A vontade de obter a justiça pela prática da lei vai de encontro à vontade de Deus e, assim, de acordo com São Paulo, é pecado. Deste modo, essa maldição da lei paulina revela o processo anterior da consciência da culpa, pois para Ricoeur:

Se olharmos para essa análise (processo anterior da consciência da culpa) à luz da experiência paulina da justificação através das obras da lei, torna-se claro que a promoção da culpabilidade - como o seu sentido apurado da responsabilidade individual, com a sua preferência pelo uso de graus e nuances na imputação, com o seu tato moral é ao mesmo tempo o surgimento da própria justiça e da maldição que se lhe cola. Em simultâneo, a própria experiência do escrúpulo é radicalmente reinterpretada: aquilo que nela não era experimentado como constituindo falta, a própria empresa de reduzir o pecado através do cumprimento da lei, torna-se pecado; é esse o verdadeiro sentido da maldição da lei (RICOEUR, 2013c, p. 60-161). 
É interessante notar que a experiência da falta leva a liberdade a tomar consciência de sua escravidão. A liberdade descobre que não pode fazer o bem, pois é serva de um poder que preenche, aliena e escraviza. Ela é um servo-arbítrio.

O conceito de servo-arbítrio liga duas ideias contraditórias: a ideia de uma "livre escolha, ou seja, livre-arbítrio, sempre jovem e intacto, sempre disponível - e a ideia de servidão, ou seja, a própria indisponibilidade da liberdade para si mesma" (RICOEUR, 2013c, p. 169). A cadeia de símbolos primários do mal (mancha, pecado, nódoa) se orienta em direção à representação da liberdade e revelam "a coincidência do livre arbítrio e da servidão no mesmo ente” (RICOEUR, 2013c, p. 169). A partir da consciência de que é serva, a liberdade tem o desejo de justificação.

Com a noção de servo-arbítrio Ricoeur pretende passar da simbólica a uma filosofia conceitual. O servo-arbítrio é primeiramente um conceito-limite. Ele em si um conceito contraditório, pois servo e arbítrio não podem coexistir logicamente, isso põe em curto-circuito a ideia de arbítrio que não pode significar uma liberdade de escolha.

\subsection{O livre-arbítrio e a justificação}

A liberdade encontra-se diante da escolha pelo mal da qual deve ser libertada. Uma liberdade que se torna indisponível é uma liberdade que "se escraviza a si mesma, se afeta e se infecta através de sua própria escolha” (RICOEUR, 2013c, p. 170). Pode-se colocar que, se a liberdade é responsável por sua servidão, ela é incapaz de mover o jugo que ela carrega. O livre-arbítrio é, assim, prisioneiro da situação que ele mesmo criou. Essa catividade do servo-arbítrio é o ato e o estado de um ser pecador no qual o próprio ato de se escravizar se abole enquanto ato e se transforma em um estado.

Esse estado de servidão que resulta de um ato de auto-escravidão, é indicado pela mancha como uma positividade na qual o mal é uma coisa qualquer, coisa que se há de tirar. A exterioridade significa que o mal não é somente intenção, mas o mal vem ao homem como o "fora" [de fora] da liberdade, como o outro no qual a liberdade é envolvida. O mal, desta forma, não vem identificado com o homem, mas é algo que está já-aí está diante de nós e nos atrai. 
O simbolismo da mancha remete à servidão da liberdade pelo esquema de infecção que "significa que a sedução pelo fora é, em última instância, uma afecção do si por si mesmo, uma autoinfecção através da qual o ato de se amarrar, transforma-se no estado de estar amarrado" (RICOEUR, 2013c, p. 170). Ou seja, a direção da infecção e da catividade. A infecção serve para clarear a ligação entre exterioridade/interioridade. Nela a "sedução" infecta, mas não destrói. O esquema da infecção significa que o si se coloca em si mesmo, que o mal radical não é a destruição do próprio ser do homem e de seu destino originário. Já na ideia de catividade a visão ética do mal não é somente um ato, mas um estado.

A identificação de um ato e de um estado como visão ética permite ver que há no homem uma sobreposição e uma coabitação do mal radical e da bondade original. Ou seja, o mal radical não é a natureza da liberdade. Ele é somente uma modalidade existencial, porém que não arruína o seu ser. É precisamente nesse sentido que Ricoeur fala de servo-arbítrio. Esse é um ato do homem, pois o ato de ligar vem do homem. Esse ato de ligar-se a si mesmo é um estado, pois "se muda" em uma situação de servidão.

A liberdade, mantendo intacta sua natureza original, torna-se por sua escolha necessitária da salvação. Ocupada e infectada por seu próprio pecado, a liberdade tem necessidade de desamarrar-se, porque "a problemática fundamental da existência não será tanto a da liberdade, entendida no sentido de uma escolha a tomar em face de uma alternativa radical, como a da libertação. O homem cativo do pecado é um homem a libertar. Todas as nossas ideias de salvação, de redenção - ou seja, de resgate - procedem dessa cifra inicial" (RICOEUR, 2013c, p. 110). O desejo de justificação procede da experiência de servidão, de catividade, bem como da impotência de desligar-se de sua falta. Apesar de tudo isso, a justificação é implorada e atendida.

A possibilidade de recusar o componente de espera, que caracteriza o desejo de justificação, é sempre concebível. Ele pode assumir o encargo de se justificar na negação de uma justiça que vem de fora. É-lhe permitido tomar sobre si o pecado e reivindicar para ele o poder de apagá-lo. Na necessidade de justificação existem sempre o componente de espera. Como também existe a possibilidade de recusa desse componente. 
A vontade de se justificar revela uma consciência culpável que se isola da comunhão dos pecadores, que rompe com a dimensão teológica do pecado e que, de maneira secreta, satisfaz-se em seu narcisismo. Curvando-se sobre si-mesma, a consciência torna-se escrava de sua vontade de justiça sem a promessa. Ela se fecha como uma vontade desesperante e desesperada no ciclo de interdito e do desejo que produz a morte. A perspectiva paulina mostra que a vontade desesperada de justiça coincide com a boa vontade, ou seja, com a vontade que aprova a exigência de um mandamento santo, justo e bom, crendo que ele pode fazer o que ele quer e que ele pode obter a justiça pelas obras prescritas pela lei.

$\mathrm{Na}$ realidade, a vontade da própria justiça é pecado e conduz à morte. Ela se opõe à vontade de Deus no que concerne ao sentido e à função da lei que, de certa maneira, rompe com Deus.

Da filosofia existencial, do eu cativo do pecado de sua própria justiça, que exalta o sujeito a ser criador de sua própria existência, é que Ricoeur suspeita, pois essa filosofia é sinal de um eu cativo, desejoso de formar um círculo com ela mesma, distanciando-se de suas condições de existência e de sua raiz ontológica.

Como então libertar essa liberdade que está presa sob o jugo de sua escolha? Que condições podem existir para essa libertação e consequentemente sua justificação?

O homem confessa sua responsabilidade pelo mal, entretanto, não pode romper as correntes que o aprisionam a esse mal. $\mathrm{O}$ poder do mal mantém a liberdade na prisão de seus atos maus, tornando-se extraviada. Isso é mostrado pelos símbolos primário da falta que se exprimem através das imagens de cativeiro e de mancha que infecta.

A instância da culpabilidade é reduzida, aparentemente, ao exterior, caracterizando pela mancha como um mal que infecta, em um símbolo de uma liberdade que escraviza a ela mesma e que, por autoinfecção. Isso suscita algumas interrogações: por que a liberdade não é capaz de se libertar do mal que ela coloca? Por que essa impotência engendra nela o desejo de justificação e quais são as condições para tal? Essas duas questões só podem ser resolvidas se incluímos o mal em uma totalidade significante. 


\subsection{No mal há um sentido existencial}

Toda a Simbólica do mal aponta para um conceito contraditório, o de servo-arbítrio. Ele é um conceito-limite, pois a simbólica nunca o conseguirá alcançar e porque isso opera sobre ele como um regulador. Em si, ele é um conceito contraditório, porque ele é simplesmente enunciação de um paradoxo entre os termos servo e arbítrio. Esses dois termos não podem coexistir logicamente:

uma vez que causa um curto-circuito entre a ideia de arbítrio- a qual só pode significar livre escolha, ou seja, livre-arbítrio, sempre jovem e intacto, sempre disponível - e a ideia de servidão, ou seja, a própria indisponibilidade da liberdade para si mesma. Assim sendo, o conceito de servo-arbitrio não se pode representar como o de falibilidade (RICOEUR, 2013c, p. 145).

Ricoeur inicia a segunda parte da Simbólica do Mal tratando dos problemas etiológicos e soteriológicos dos mitos do princípio e do fim.

O que é um mito? $\mathrm{O}$ mito se define como narração tradicional destinada de maneira geral a instaurar todas as formas de ação e de pensamento pelos quais o homem se compreende a si mesmo em seu mundo. Os mitos, assim, são entendidos como símbolos de segunda ordem que nos descobrem e manifestam a união do homem com o sagrado.

Para nosso autor, se o mal está sempre já-aí, ou seja, não é algo objetivo nem tem uma origem atribuível, é necessário percorrer o mundo dos símbolos e dos mitos que tentam explicar o mal.

O símbolo é determinado tipo de linguagem. A linguagem é a mediação necessária para a recuperação da experiência. Mais que uma recuperação é uma reapropriação e esclarecimento de uma experiência confusa, a do mal. Neste sentido, a linguagem nos constitui. Somente através dela, através de sua interpretação, nos apropriamos de nós mesmos.

Os símbolos primários não comportam uma dimensão narrativa. Já os mitos contam o começo e o fim de uma experiência que os símbolos primários testemunham. É, então, pela narração que o mito dá significado à totalidade. 
O mito, ligado ao rito, exprime a participação vivida e sentida a um ato original. Se se crer que na fenomenologia da religião existe uma relação da marcha com o sagrado, ela forma uma via que integra o ser e que precede toda palavra.

A palavra é que constitui toda estrutura mítica da consciência e forma a matriz de todas as expressões míticas que visam à elucidação do mal. Ricoeur nos fala que a estrutura mítica representa "o acordo íntimo do homem do culto e do mito com a totalidade do ser" (RICOEUR, 2013c, p. 185). O mito não deve ser somente um avivamento histórico, nem uma explicação etiológica, nem uma gnose, uma forma de conhecimento universal e totalizante. $\mathrm{O}$ mito é essencialmente símbolo. Sua função simbólica está em significar a plenitude originaria pela qual o sobrenatural, o natural e o psicológico ainda não estão divididos. Essa plenitude é apenas visada, que assegura a convergência entre reflexão e interpretação, no horizonte de uma poética da liberdade e não dada, pois o mito:

É a narrativa tradicional sobre os acontecimentos que tiveram lugar na origem dos tempos, destinada a fundar a ação ritual dos homens dos dias de hoje e, de maneira geral, a instituir todas as formas de ação e de pensamento através das quais o homem se compreende a si mesmo no seu mundo. Essa [...] integridade que é visada pelo mito não passa de uma intenção. É na medida em que ele próprio perdeu essa integridade que o homem a repete e a imita através do mito e do rito. O homem primitivo já é o homem de cisão. Daí em diante, o mito será apenas uma restauração ou uma restituição intencional e, nesse sentido, já simbólica (RICOEUR, 2013c, p. 185).

Essa plenitude, o mito a designa pelo termo história fundamental. Ela narra a instauração, a perda e a restauração da plenitude. Assim sobre a plenitude: "não é dada: não só porque é significada e não vivida, mas porque é significada mediante um combate"(RICOEUR,2013,p. 187). Se se pode dizer, o mito recebe do drama original a "discursividade" da narrativa, pois "esse drama original abre e revela o sentido oculto da experiência humana" (RICOEUR, 2013, p. 187). É nessa totalidade não vivida, mas designada por esse drama original que a experiência da falta deve ser substituída. É na dimensão mítica, ou graças a ela, que a falta surge no seio de uma totalidade onde são evocados seu começo e seu fim. 


\subsubsection{O sentido e o Mito Adâmico}

Para Ricoeur o significante total que engloba a experiência da falta pode ser colocado pela opção da multiplicidade de mitos do começo e do fim do mal. Entretanto, há de se elaborar uma tipologia desses mitos. Mas há de se perguntar como fazer com que a neutralidade filosófica não seja afetada pelas etapas tipológicas da interpretação dos mitos?

Essa é a dificuldade que a opção pelo mito nos impõe, mas ninguém pode se interrogar a partir de um lugar que não existe, por isso é preciso se situar em algum lugar e esse lugar, para Ricoeur, no qual se pode escutar, ouvir e compreender a instrução dos mitos em seu conjunto, é no mito adâmico.

O mito adâmico, a exemplo de outros mitos, dá à história um movimento que tem começo e fim, de como o homem era inocente e passou a ser culpado. Esse mito é um mito antropológico por excelência. A sua elaboração é de situar historicamente, na linha da experiência hebraica do pecado e da culpa, em conjunto com o juízo e da misericórdia e finalizar com a reflexão de Paulo sobre o velho Adão e sobre o novo. Ricoeur toma o texto bíblico do mito adâmico para mostrar que a função simbólica desse mito só pode ser mostrada por meio da narração humana. Tudo isso implica na dissolução dos pressupostos teológicos dos mitos teogônicos e trágicos, pois afirma o monoteísmo ético de um deus bom. A análise desse mito mostra uma afirmação central que a origem radical do mal é distinta da origem do ser bom das coisas. Logo, se a criação é início absoluto das coisas, o homem é o início do mal com o seu ato livre.

Temos que ter em mente que o mundo dos mitos não é um universo tranquilo e reconciliado, mas um espaço que prepara uma abordagem filosófica. O mito adâmico tem por intenção "de ordenar todas as outras figuras a partir da de Adão, e em compreendê-las em ligação com ela, e como que na fronteira da narrativa cujo principal protagonista é Adão" (RICOEUR, 2013c, p. 254). Assim, em primeiro lugar, esse mito convém a uma cristologia, ou seja, ao anúncio da salvação por Cristo em uma doutrina da justificação pela fé. É um mito que contém um começo e um fim. Ao narrar o início de uma criação boa, esse mito, admite que a primeira e a última palavra da história humana não é o mal. 
O mal que é o cativeiro do homem e deve ser superado. Superado por uma redenção anunciada pelo mito adâmico e comprovada pelo filósofo fundado na força reveladora do símbolo. Na verdade, o que é a "descrição do pecado e a simbolização de sua origem, por meio do mito adâmico" senão "o reverso de uma palavra de libertação e de esperança” (RICOEUR, 2013c, p. 442).

Essa narrativa sugere que a conduta é um drama, uma ação promulgada, especialmente se notarmos a figura da serpente. Ela é o símbolo do desejo que é vítima de si mesmo, o cativo infinito do desejo que perverte o homem no sentindo de um limite que orienta a liberdade. A serpente é a exterioridade do mal, pela qual o homem cede por sedução pelo que está fora. Ou seja, o mal já está lá e que todos o encontra sem o iniciar. O mal que escapa à liberdade responsável do homem é o testemunho ulterior que o homem não é a origem do mal e que de outra parte, tal origem não é dualistamente coextensiva ao bem, pois o homem não é o pecador absoluto, nem pecador em segunda, mas por sedução. O mito, assim, recapitula todo mal da história em um único acontecimento e unifica a humanidade na figura de Adão, que é o paradigma da multiplicidade e unidade humana.

A segunda razão é que a narração bíblica da queda procede simbolicamente de uma significação que esclarece a existência humana e dá uma compreensão mais adequada ao advento da salvação na qualidade de prolegômeno da fé.

A Terceira, o mito adâmico não somente introduz uma oposição no mundo dos mitos que polariza duas tendências "aquelas que transferem o mal para além do humano e aquela que o concentra numa escolha má, a partir da qual começa pela pena de ser homem” (RICOEUR, 1999, p. 289-290). Esse mito também é portador do conflito da origem do mal. Desta maneira, "a apropriação do mito adâmico acarreta a apropriação em cadeia dos outros mitos que falam a partir do lugar de onde o mito dominante se dirige a nós" (RICOEUR, 2013c, p. 328). Nesse mito em particular, existe uma tensão escatológica, pois em si, contém a promessa de cumprimento, pois isso ele pode ser lido a partir dos símbolos do fim. A história de Abraão, dos patriarcas, do Filho de Davi, do Filho do Homem representam as etapas de uma originária e progressiva escatologização. Pelo movimento do fim, compreendemos o início. 
Em Paulo, o perdão supera a imagem jurídica do pagamento, para conquistar o sentido de remissão no processo escatológico. De tal modo, o perdão é algo mais que um simples fato psicológico ou de uma relação dual, pois torna-se um fato comunitário e cósmico.

A dinâmica dos mitos desobstrui um espaço orientado através do qual é possível recolher a mensagem de um conjunto de mitos a partir da perspectiva da confissão judaica e cristã dos pecados. Na realidade, o ângulo de perspectiva é mais cristão que judeu, pois ele mostra a convergência do mito adâmico à cristologia, o anúncio da salvação através de Jesus Cristo. Podermos dizer que o anúncio é que forma a verdadeira pressuposição da mediação de Ricoeur sobre a falta.

Cabe-nos agora abordar o mito adâmico como ruptura entre a ontologia e a história.

\section{$1.5 \mathrm{O}$ ser e a história}

O mito, por assim dizer, é a nossa mentalidade histórico-crítica do drama humano, não pode ser vivido nem como acontecimento histórico, nem como uma explicação etiológica e muito menos como gnose, ou seja, uma forma de consciência que pretenda dar cabo de um conhecimento universal e totalizante. $\mathrm{O}$ mito é essencialmente símbolo. A função simbólica está em significar a plenitude originária que o sobrenatural, o natural e o psicológico mantêm cindida. Tal plenitude não pode ser mais visada ou dada, mas deve ser intencionada e significada a partir da função simbólica.

Ricoeur afirma mais de uma vez que a narração do mito adâmico é antropológica, pois nela o homem não constitui a origem do mal. $\mathrm{O}$ mito fornece uma expressão mítica da experiência penitencial de Israel, ele está enraizado na confissão judaica dos pecados, explicita a tendência de universalizar o pecado como atos maus originados de uma decisão singular.

No mito adâmico, o mal não pode ser reduzido ao mal atual, porque está no homem com um fundo de uma trágica pecabilidade, por isso, esse mito reafirma algo de trágico. Ele evidencia que a antropologia não basta-se e que a 
simbólica do mal não pode exaurir a questão do mal. Em suma, não pertence a esfera da competência de uma antropologia do mal a solução dos problemas que foram suscitados. A resposta viria, segundo, Ricoeur, no campo de uma poética da liberdade e através do homem que ascende a possibilidade de uma antropologia filosófica ou mesmo uma cristologia capaz de incluir na vida mesmo de Deus, em uma dialética da pessoa divina, a figura do servo sofredor evocada como possibilidade suprema do sofrer humano.

A confissão é uma dimensão do mal que mostra a santidade absoluta de Deus e pela qual o mal decorre de uma escolha humana, a escolha de Adão. Adão com seu ato exprime a humanidade inteira, unifica dentro de uma culpabilidade indivisa: designa o nós pecadores na confissão dos pecados e na comunhão pecadora. $\mathrm{O}$ mito adâmico concentra a tensão que está inserida na confissão judaica, a saber, a santidade de Deus e o mal no homem. Se a raiz do pecado é formada pelo ser do homem, a acusação profética não retorna a Deus que é criador dessa natureza? O fiel que comete o mal não se acusara perante Deus ao mesmo tempo que Deus o acusa? E se Deus é acusado, a dupla confissão judaica não é profundamente abalada?

O mito adâmico dentro de um momento de tensão da experiência penitencial judaica tem por função "estabelecer um 'começo' do mal, um acontecimento pelo qual o pecado deu entrada no mundo e, através do pecado, a morte" (RICOEUR, 2013c, p. 261). Ele é o mito do surgimento do mal dentro de uma criação boa. Desta forma, a Origem é uma origem da bondade da criação e da maldade da história. O mito adâmico satisfaz a dupla confissão do judaísmo: a perfeição absoluta de Deus e a maldade radical do homem que é "o próprio espírito da sua penitência" (RICOEUR, 2013c, p. 262).

Para Ricoeur, o mito adâmico explora o ponto de ruptura entre a ontologia e a história. Ao homem é atribuída a responsabilidade do mal que ele "começa" no sentido de uma criação que teve início absoluto no ato criador de Deus.É através do homem e de seus atos que o mal entrou no mundo, em uma criação boa. $\mathrm{O}$ mito elabora uma antropologia de ambiguidade que sobrepõe e opõe dois regimes existenciais, a inocência e a pecabilidade (condição do ser 
humano de estar propenso ao mal mediante uma escolha livre, ou seja, a concepção da responsabilidade pelos atos não conformes à lei moral).

A queda como acontecimento começa no instante que encerra a inocência e começa a culpabilidade. Se o instante marca a análise entre o passado e o futuro, ele constitui ponto de união. Por causa dessa função do instante, de separação e união, toda atividade humana se refere ao destino originário do homem e seu mal radical. Ricoeur nos diz que: "toda dimensão do homem - linguagem, trabalho, instituição, sexualidade - tem como empresa a dupla marca do bem como destino e da tendência para o mal" (RICOEUR, 2013c, p. 265). É possível interpretar os dois estados, inocência e culpabilidade, como duas modalidades coexistentes na compreensão de homem. $\mathrm{O}$ homem é simultaneamente bom e pecador. $O$ pecado não sucede a inocência, mas a perde através do instante. O instante aplica o papel da coisa-em-si do kantismo a inocência deve ser pensada não mais com um estado histórico anterior, mais com uma realidade que limita a pretensão de um fenômeno histórico do pecado a se igualar no ser do homem. Para Ricoeur,

Afirmar o mundo como aquilo no qual o pecado desviou, ou a inocência como aquilo a partir do qual o pecado se desviou, ou ainda, metaforicamente, o Paraíso como o lugar de onde o homem foi expulso, é atestar que o pecado não é nossa realidade originária, não constitui o nosso primeiro estatuto ontológico. O pecado não define o ser-homem; para lá do seu devir-pecador está o seu ser-criado (RICOEUR, 2013c, p. 269-270).

A inocência significa o ser-criado e é este estado da criatura que constitui a bondade original do homem à imagem de Deus. Se a inocência, a partir do pecado, é um estado anterior àquele caracterizado pela culpabilidade, devemos reconhecer que a razão de sua identidade com a semelhança divina "façamos o homem à nossa imagem" $(G n, 1,26)$ - coexiste com o pecado do homem. $\mathrm{O}$ instante da queda não suprime o instante da criação, ou melhor, o instante da existência humana comporta simultaneamente a inocência e a pecabilidade. Assim, o mal transcende o estatuto ontológico do homem. 
Se a inocência significa a bondade do homem em sua origem e o status de criatura, mesmo se não vivesse seu destino para o bem, o homem não cessaria de ser bom, pois constantemente é criado. Por exemplo: João não pode cessar de ser uma criatura, mesmo que ele rejeite o seu status de criatura. Desta forma, somente a recusa é histórica enquanto que a criação é ontológica.

A distensão temporal do mito exprime a coabitação no homem de uma natureza originariamente boa e de um mal radical, porém contingente. Diante da contingência, o mal perde seu caráter de fatalidade e deve ser susceptível a um fim. Ricoeur nota que a contingência do mal não dissolve por inteiro seu aspecto trágico e inelutável que o mito adâmico relata.

Ricoeur afirma que "por mais radical que seja o mal, ele jamais será originalmente como a bondade" (RICOEUR, 2013c, p. 175). Ou seja, o mito da queda somente é possível no contexto de um mito de criação e inocência, no qual a bondade é sempre mais originária que o mal. Se todos os mitos da queda narram o momento de criação e do cair do homem, eles também nos mostram a riqueza simbólica na qual o mal surge no Instante, o homem não é um malvado absoluto, um mal primordial. Contudo, o mal não é simétrico do bem, a maldade não é o substitui a bondade do homem. Eles não são mais que corrupção, o obscurecimento e a fealdade de uma inocência, de uma luz e de uma beleza que, ainda assim, continuam a existir.

O pecado no momento da queda não sucede a inocência, mas no Instante, perde-a. Ricoeur nos coloca que não posso deixar de ser criado, pois se o deixo, não existo, logo se existo não deixo de ser bom, pois fui criado bom. Logo, quando há o acontecimento do pecado, a inocência cessa, no Instante. O acontecimento do pecado é a descontinuação e a fratura do meus ser criado e do meu vir a ser mau.

\subsection{Existe um Deus mal na da visão trágica da existência?}

É justo dizer que a narração da queda não remete somente ao salto qualitativo da inocência à falta, mas mostra a possibilidade e a motivação da falta em meio a uma dura tentação, que está no intervalo que vai da inocência 
à queda, por seus personagens: Adão, Eva e a Serpente. Contudo, Ricoeur se detém na última figura, por considerá-la um resíduo mitológico dentro de um mito antropológico, no qual é ultrapassado em uma exegese dos mitos, para encontrar uma filosofia dos símbolos, ou seja, não ver por trás do símbolo, mas a frente, pois o símbolo dá à pensar.

O conflito dos mitos é incluído num só mito. É por isso que o mito adâmico, que, do primeiro ponto de vista, podia ser considerado como efeito de uma enérgica desmitologização de todos os outros mitos que dizem respeito à origem do mal, introduz na narração a figura altamente mítica da serpente (RICOEUR, 1999, p. 190).

A serpente é o único ser que se conserva em meio aos mitos teogônicos e que não foi desmitologizado. A literatura Javista representa, com a serpente, um aspecto importante da experiência do mal, uma causa exterior capaz de tentar o homem. Essa tentação é uma espécie de sedução. Todavia, a serpente não representa o Príncipe das Trevas, Satanás, mas uma parte de nós mesmos que não reconhecemos. Paulo identifica essa causa exterior da "concupiscência da carne" como a lei do pecado que habita em nossos membros. A serpente representa o aspecto passivo da tentação, ou melhor, uma projeção psicológica da concupiscência. Para nosso filósofo, essa "redução da serpente a uma parte de nós mesmo não esgota, possivelmente, o símbolo da serpente. A serpente não é apenas projeção da sedução do homem por ele mesmo [...] é também 'exterior' de uma forma mais radical e, aliás, múltipla” (RICOEUR, 2013c, p. 176). Sobretudo, para Ricoeur, a serpente indica que o mal já está aí. O mal não é somente acontecimento, ele forma parte da conexão inter-humana que transmite a tradição através da linguagem. Por isso o mito adâmico é um mito antropológico como vimos.

Como nos é conhecido, o homem cai por que a serpente seduz a mulher. Essa passagem da sedução é muito tênue, pois o mito adâmico propõe a sedução como razão dos atos maus.

A questão da sedução pela serpente insinua uma dúvida sob o sentido da interdição divina que o autor bíblico coloca ingenuamente no regime ontológico da inocência. Em contrapartida, para Ricoeur, 
Deve-se, sem dúvida, compreender que ao criar o homem livre, Deus deu-lhe uma liberdade finita. A finitude dessa liberdade consiste nisso: que ela é desde a origem orientada, não, sem dúvida, por aquilo a que chamamos "valores", que são produtos culturais já muito elaborados, mas por um princípio de hierarquização e de preferência entre os valores. Esta estrutura ética da liberdade constitui a própria autoridade dos valores em geral (RICOEUR, 2013c, p. 167).

Dessa forma, com a essência da liberdade finita aparece a limitação essencial que orienta e guarda a liberdade na criação e alimenta sua autonomia pela autoridade primitiva de valores. $\mathrm{O}$ interdito é uma "qualidade de autonomia que tornaria o homem o criador da distinção entre o bem e o mal" e não receptor de valores. $\mathrm{O}$ homem, nesse caso, para conservar essa atitude de acolhimento da autonomia, tem que ter uma relação de confiança em Deus.

A relação de confiança em Deus é uma questão perturbadora que a serpente tentadora põe. A promessa da serpente, "sereis como Deuses", marca no homem o nascimento do desejo ilimitado que torna insuportável a finitude, obscurecendo o sentido do limite e suspeitando da boa-fé do interdito divino. O limite cessa de ser criado e Deus parece barrar o caminho do homem com seus interditos. Por sua liberdade o homem se coloca com uma criatura de si para si. Esta situação finita da criatura, é o desejo do mal infinito que se apodera da liberdade e que coloca que Deus não quer a autonomia do homem, mas a sua servidão.

Diante disso, a tragédia grega desenvolve precisamente o tema da inveja divina. Ela indica a revolta do homem que resolve assumir seu destino em relação e contra todos os deuses. A inveja divina forma o descomedido humano que provoca a cólera dos deuses. Os sábios gregos pregaram uma modéstia na qual reside a origem do trágico e os assombram pelo receio de uma desmedida insuportável à inveja divina. A concepção de um Deus que é rival do homem resulta de uma aceitação resignada, trágica e servil de sua condição limitada ou o desafia a querer rejeitar a fé nesse deus em sua própria finitude.

O homem é levado a um destino absoluto ao qual será aprisionado. A liberdade de desafio se engaja em endossar a carga de seu destino e o conduzir 
através de uma existência trágica. A promessa de todo poder que ela alimenta se depara com a finitude inelutavelmente inerente à realização de si.

O requerimento de tornar-se si mesmo implica na exclusão e na destruição, não somente das possibilidades, mas das realidades e das existências. O caráter "destinal" da liberdade, atestado no exercício da liberdade, parece necessariamente como um defeito, uma falta:

Essa já não é uma falta num sentido existencial: tornar-se si mesmo é falar na concretização da totalidade que permanece, contudo, o objetivo, o sonho, o horizonte indicado pela Ideia da felicidade. Na medida em que o destino pertence à liberdade como a parte não escolhida de todas as nossas escolhas, ele deve ser experienciado como falta (RICOEUR, 2013c, p. 231).

Ricoeur faz notar que o trágico da liberdade consiste em renegar a condição finita, contudo, sem abolir essa condição. $\mathrm{O}$ homem pode decidir suportar essa condição, mas esse orgulho é ainda uma homenagem ao caráter indispensável da finitude humana. $\mathrm{O}$ desafio se torna uma falta moral e essa falta moral atribui à finitude sua mordida e seu despeito. A finitude não é chamada mais à participação, mas à revolta.

A teologia trágica vem substituir a antropologia trágica. $\mathrm{O}$ crente reconhece a particularidade dolorosa de sua liberdade como uma pena e confessa a possibilidade de um Deus malvado.

O homem ao admitir, através da consciência religiosa, que é vítima de uma agressão divina, rompe a possibilidade de uma relação fiduciária com Deus que é definida pela religião cristã. A consciência religiosa é incapaz de admitir um Deus malvado, somente uma consciência ímpia é capaz.

A teologia bíblica atesta a incerteza de uma consciência religiosa judaica e que a confissão dos pecados ultrapassa a responsabilidade individual. Já o pecado comporta o aspecto coletivo que excede a imputação pessoal e que cria uma situação exterior, um meio no qual o indivíduo se encontra. $\mathrm{O}$ mal aparece com um ato que começa e continua. Pois para Ricoeur, "o mal faz parte da ligação inter-humana como a linguagem, como o utensílio, como a instituição, é transmitido, é tradição e não apenas acontecimento; há, assim, uma anteriori- 
dade do mal em relação a ele mesmo, como se o mal fosse aquilo que se precede sempre a si mesmo, aquilo que cada um encontra e continua começando-o, mas começando-o por sua vez" (RICOEUR, 2013c, p. 271).

A anterioridade do mal é exprimida no mito pela figura de Adão e da serpente. Adão é o primeiro exemplar e representa "a experiência do 'começo' da humanidade em cada indivíduo, e em simultâneo, a experiência como a da 'sucessão' dos homens” (RICOEUR, 2013c, p. 277). Cada homem peca como Adão. A serpente é a exteriorização do mal que já está no jardim do Éden.

A serpente representa, no próprio coração do mito adâmico, a outra face do mal, que os outros mitos tentavam contar: o mal já aí, o mal anterior, o mal que atrai e seduz o homem. A serpente significa que o homem não começa o mal. Ele encontra-o. Para ele, começar, é continuar. Assim, para além da projeção da nossa própria cobiça, a serpente figura a tradição de um mal mais antigo que ele próprio. A serpente é o Outro do mal humano (RICOEUR, 1999, p. 290).

A figura da serpente é um álibi para nossa liberdade. $O$ homem tenta a partir dela se justificar alegando a irresistibilidade da tentação. É interessante notar que ceder à sedução é muito menos ceder ao mal que a si mesmo. De fato, o objeto que nos tenta e que descobre o nosso desejo é o objeto no qual temos projetados nossos desejos e que nos "obriga" à concupiscência. A liberdade, investida pela concupiscência, desenvolve no objeto da concupiscência uma quase exterioridade da sedução que exprime o elemento passivo que a serpente representa.

A serpente não esgota sua significação na experiência de sedução que projeta o objeto de nosso desejo. É ela que desperta a nossa cobiça. Como Paulo diz: "Eu não teria conhecido a concupiscência se a Lei não me tivesse dito: não cobiçarás" $(R m 7,7 \mathrm{~b})$. O mal é a realidade pela qual a história humana manifesta a existência e a possibilidade de todos os homens que entram no mundo. Dentro da conexão e da sucessão históricas o mal é sempre mal subsequente e salto imprevisível. Ele é um mal que vem aumentar o favo do pecado que cresce quantitativamente. 
Aqui vale salientar que conforme Sören Kierkegaard (2004, p.36), o pecado, entra no mundo subitamente, quer dizer, mediante um salto. Este salto põe ademais a qualidade, e no mesmo momento de ser posta a qualidade tem lugar o salto de qualidade, de maneira que a qualidade supõe o salto e o salto supõe a qualidade. $\mathrm{O}$ mito apenas exterioriza o que é interior. Isso quer dizer que o pecado acontece em outras partes, de maneira que, segundo o autor, daria nos mesmos termos no mundo apenas um Adão como mil Adãos Assim, Kierkegaard aproxima o pecado de Adão dos outros pecados e Adão dos outros homens e coloca que nesse movimento é que surge a queda, e a psicologia não poderia explicar a queda, porque se trata de um salto quantitativo.

Alguém poderia objetar que não é somente pelo pecado que a história humana é fornecida, mas também pela estrutura cósmica. O curso do mundo parece indiferente "à exigência ética da qual o homem é simultaneamente, o autor e servo; do espetáculo das coisas do curso da história, da crueldade da natureza e dos homens, procede um sentimento absurdo universal que convida o homem a duvidar do seu destino" (RICOEUR, 2013c, p. 277). Desta maneira, surge com violência a visão trágica do mundo que não deixa aparecer a visão moral.

O homem resulta da tomada sua responsabilidade e de sua impotência do querer, de forma que a consciência ver o mal como algo incapaz de ser incluído em uma liberdade responsável do homem delineia uma concepção trágica da existência humana testemunhada no livro de Jó. O sofrimento do justo mostra a escolha moral que estabelece uma linha causal entre o mal sofrido e o mal cometido. A teoria da retribuição implica em uma apreciação da conduta homem em relação a Deus.

Na visão moral, Deus é um Deus ético. Ele zela pela execução da lei e julga a retribuição a cada um segundo as obras. $\mathrm{O}$ julgamento divino é processado na história. A história "é um tribunal, os prazeres e as dores uma retribuição, e onde Deus, por sua vez, se torna um juiz. Da mesma forma, a totalidade da experiência humana assume um caráter penal" (RICOEUR, 2013c, p. 232). O sofrimento é, muitas vezes, sinal e sanção do pecado. Pela consciência moral o sofrimento não é um problema. Ele é a justa punição de um ato mau. Quando a consciência religiosa percebe que a lei da retribuição 
não dá conta de todas as maldades do mundo, "o sofrimento surge como enigma quando a exigência de justiça já não pode compreender" (RICOEUR, 2013c, p. 233). Nesse interim, o sofrimento "injustificável” coloca em questão o Deus ético. Pois, apesar de Deus ser "todo poderoso; Deus é absolutamente bom; contudo o mal existe" (RICOEUR, 1988, p. 21).

Kant se inspira em Jó e admiravelmente mostra o insucesso de toda teodiceia (Cf. RATEUX, 2011, p. 243-244), o desaparecimento de uma visão ética em vista de uma clareza jurídica e o obscurecimento da profundeza insondável do criador. Ele expôs que é inútil construir uma onto-teologia destinada a conciliar o curso do mundo com as exigências morais.

A reconciliação das duas ordens, a unidade que elas formam escapa ao nosso entendimento finito, que está cravado dentro da sabedoria de um Deus abscôndito que se revela como um Deus aterrorizante. Assim Jó, reconhecendo o vazio da retribuição e ascendendo à experiência do trágico, não se torna um agnóstico. Ele confessa humildemente o caráter do Deus abscôndito e reconhece a sabedoria divina que é inacessível ao homem. Assim existe uma nova dimensão da fé, a fé não verificável. Por esse tipo de fé, Jó enxerga, na revelação de Deus a partir do infortúnio que sofre, a existência de uma plenitude de sentido que engloba o homem e na qual o homem não é mais o centro.

A contemplação da totalidade provoca e implica na morte da exigência da retribuição que anima a recriminação e manifesta a preocupação com a singularidade individual. A fé no Deus escondido não dá explicação ao sofrimento de Jó. Ela apenas depura seu olhar e dá o aceite a seu sofrimento como um dom de Deus. Jó concorda com sua condição. Através de seu sofrimento ele abandona a pretensão de ser centro do universo para descobrir a sua existência na totalidade insondável de sentido.

O sofrimento, dessa forma, não pode mais ser compreendido como castigo. A teologia trágica, assim, é possível. O profeta que convoca a uma vida de santidade, faz com que o homem note o abismo entre ele e Deus no temor e tremor.

A fé tem um caráter, ou nota de inverificável que é a injustificabilidade do mal. $\mathrm{O}$ mal suporta que exceda toda exigência de justiça. Por causa da in- 
justificabilidade do mal, existe a possibilidade de que na consciência o Deus abscôndito seja o Deus malvado.

A culpabilidade inevitável da existência fracassa em realizar de um só golpe a totalidade pela qual ela aspira. Como não é possível justificar o que pesa sobre o inocente, o mal não encontra a sua justificativa. Nesse sentido resta a pergunta seria Deus malvado? Quererá ele a dor do inocente?

O radical do mal radical que é o contrário da confissão do mal fornece o cerne da iniquidade que responde ao polo humano. Ao mesmo tempo, esse mesmo radical constitui um polo não humano do mal e medita a perda do homem.

Se, a consciência religiosa hesita em colocar o cerne da iniquidade na divindade, corre o risco de se abolir como consciência religiosa. E, nesse caso, não sente mais a possibilidade de uma divindade malvada. $\mathrm{O}$ mal que é começado não é um mal submetido. Ele se produz na exigência moral da justa retribuição em uma contradição insolúvel e não resolvida. A injustiça injustificável se orienta em direção a injustiça do Juiz.

No trágico há uma contradição, enquanto ele é invencível em nível humano da experiência do sofrimento; ele também é impensável ao nível de Deus, pois a consciência religiosa não é capaz de ir além da possibilidade de representar um ser divino e diabólico em um mesmo ser. Uma consciência como essa se destruiria por minar fundamentalmente a religião, ou seja, a confissão da santidade divina.

Nesse ponto, a teogonia se oferece como "único meio de tornar a tragédia ao mesmo tempo invencível e inteligível; ela consiste, em último caso, em colocar o trágico na origem das coisas e em fazê-lo coincidir com uma lógica do ser, por meio da negatividade" (RICOEUR, 2013c, p. 346). Para Ricoeur, o trágico-lógico do ser, herdado da teologia babilônica, é uma ontogênese, pela qual há a eliminação do deus malvado, ao mesmo tempo que esse torna-se um momento lógico da dialética do ser. No devir do ser, a ordem é terminal que se conquista sob um fundo originalmente caótico e co-extensivo para a geração do ser. Contudo, para Ricoeur, não estamos preparados para dar uma resposta a tragi-lógica do ser, pois 
a resposta pertence a uma "Poética" da liberdade e do ser- do homem que exerce as possibilidades de uma antropologia filosófica; tudo que o que a reflexão sobre os símbolos e os mitos do mal nos permite compreender, é que a posição do mal pelo homem revela um inverso do mal, um momento não posto, misturado com a posição do mal pelo homem; este momento não posto remete, por sua vez, para um outro diferente do homem, representado pela Serpente (...) a preeminência do mito adâmico faz pensar que o mal não é uma categoria do ser (...) assim, uma antropologia do mal não pode afirmar nem negar o direito de uma gênese absoluta do ser à qual o mal pertenceria originalmente (RICOEUR, 2013c, p. 346-347).

A figura de um Deus malvado destruída em favor da proclamação da inocência na qual o homem convida a se inserir na longa etapa da existência humana. $\mathrm{Na}$ visão tragi-lógica, o mal é o passado do ser enquanto Deus é seu futuro, a esperança que me anima. O mal é o motor da ordem divina. É tanto que ele é o motor que aparece no universo divino como uma dor negativa. Lamuriar-se desse mundo não serve de nada, pois "a violência inscreve-se na origem das coisas, no princípio que instaura enquanto destrói” (RICOEUR, 2013, p. 200). A criação do cosmo convida inevitavelmente à destruição do caos, como nos é o caso dos mitos gregos. A ordem terminal justifica a violência atual, pois é a condição indispensável dos eventos da Ordem Divina.

Muito embora reconhecendo o caráter sedutor do trágico-lógico do ser, Ricoeur duvida de sua verdade. Pois, o "mito adâmico faz pensar que o mal não é uma categoria do ser" (RICOEUR, 2013c, p. 347). Se a serpente constitui um resquício das teogonias babilônicas e que a fé de Israel a orientou contrária a uma personificação de um mistério de iniquidade representado pela figura do diabo, jamais essa figura será considerada como outro deus, pois o judeu se recordará que a serpente é parte da criação.

Contudo, se a serpente é uma criatura como as outras coisas criadas, ela não pode ser um ser ao mesmo tempo originário que Deus no qual tudo o que se origina é dividido em: uma origem ontológica da bondade e uma origem histórica da maldade do ser criado. Conforme Ricoeur, se seguirmos até ao fim a intenção do tema da serpente, é preciso dizer que o homem não é o mal- 
vado absoluto, mas o malvado em segundo grau, o malvado através da sedução; não é o Mau, o Maligno, de forma substantiva, por assim dizer, mas antes mau, malvado, de forma adjetiva; torna-se malvado por uma espécie de contra-participação, de contra-imitação, por consentir numa espécie de mal que o autor ingênuo da narrativa bíblica descreve como astúcia animal. Pecar é ceder.

O mal, afligido pela contingência, vai além do ato humano em uma espécie de origem inumana, constituída no Adversário anterior ao homem, mas não cooriginário com Deus. Existe uma face demoníaca da experiência humana do mal que é descoberta pela estrutura quase exterior da tentação e que designa o outro aspecto do mal, desse mal pelo qual o homem é responsável. Esta é a extrema fronteira da experiência do ser que sempre tenta, no mal que nós inauguramos, ser representado na figura-limite do Diabo, pois ela exprime o cerne extra-humano do mal. A experiência da tentação descobre, assim, não somente o inverso do pecado mais também outro polo do mal humano, pois o "mal que assumo torna evidente uma origem do mal que já não posso assumir, mas da qual participo sempre que por minha causa o mal entra no mundo como pela primeira vez. Seria possível afirmar que a admissão, a confissão, do mal como próprio do humano suscita uma admissão de segundo grau, a do mal como desumano" (RICOEUR, 2013c, p. 332).

Esse outro mal, para Ricoeur, não ultrapassa somente minha responsabilidade, mais vai além de meu poder de especulação. Para lá do limite da tentação, fora de toda antropologia do mal, o estudo sobre esse mal desumano é muito perigoso, ao menos pela vida da especulação religiosa, na medida em que se aventura por um terreno inacessível à verificação. Sendo assim Ricoeur diz que, "fora da estrutura quase exterior da tentação, a qual ainda é uma estrutura do pecado do homem, eu não sei o que é Satã, se é sequer alguém. Porque se fosse alguém, seria necessário interceder por ele, o que não tem qualquer sentido" (RICOEUR, 2013c, p. 279).

A situação que homem representa é de um ser que é, ao mesmo tempo, vítima e culpado pelo mal. Ele o comete e lhe é submetido de certa maneira. $\mathrm{O}$ relato de Jó mostra que a desgraça recai sobre ele, sem que seja possível detectar nele o mínimo de responsabilidade pelo seu sofrimento. Esse mal a que Jó 
é submetido, esse mal gratuito, guarda em suspense a questão trágica do mal: Deus é malvado? Essa questão se amplifica e repercute sobre o servo-arbítrio.

Como escapar dessa teologia, cujo desdito do homem é cometer e sofrer o mal, que suscita a experiência da tentação e os limites humanos que escolhe como centro de perspectiva um mito que exclui a teogonia quando declara que o mal é contingente?

Podemos dizer que o mito adâmico e o mito trágico oferecem duas interpretações da existência, polarizada, irredutível e implicadas uma dentro da outra. Pela perspectiva do sofrimento, a tragédia livra o homem que é vítima de uma agressão transcendental. Dessa maneira, ela corrige a visão moral do mundo que manifesta o mal e que passa a responsabilidade ao homem. Mas desse mal injustificado, o homem toma consciência quando descobre a impossibilidade de integrar o mal na confissão que ele faz.

O excedente da confissão põe a visão ética em exprimir o reconhecimento do trágico que transborda de sua própria responsabilidade. $\mathrm{O}$ esforço moral para reduzir o mal à medida de uma responsabilidade humana fracassa em assumir inteiramente a responsabilidade pelo mal. Ele atinge sua saturação e seu ápice na descoberta do inverso, isto é "o não-posto na posição do mal, o sempre já-aí do mal, o outro da tentação, enfim, a incompreensibilidade própria de um Deus que sente ser meu inimigo e me pode aparecer como tal"(RICOEUR, 2013c, p. 342).

A irredutibilidade dos dois mitos manifesta um estado no qual nossa compreensão se coloca em mostrar sua incapacidade de superar a contradição que ela revelou. Por outro lado, "o mal cometido implica um justo exílio: trata-se da figura de Adão; mas, por outro lado, o mal sofrido implica um injusto despojamento: trata-se da figura de Jó" (RICOEUR, 2013, p. 342).

$\mathrm{O}$ mito teogônico busca precisamente resolver essa dicotomia. Erigindo o trágico em um momento do ser, a dicotomia mostra que convém realizar toda justiça dessa maneira. Mostra, ainda, a possibilidade de se satisfazer essa visão trágico-lógica do mundo e nutrir a esperança que no fim dos tempos soará como um triunfo glorioso da ordem diante dos acontecimentos escatológicos. A salvação futura é um acontecimento novo dentro da criação e da queda, pois "a separação entre a problemática do mal e a criação é levada a cabo (...). É, então, 
o próprio 'acontecimento' da queda que carrega todo peso desta mítica como a ponta de uma pirâmide invertida" (RICOEUR, 2013c, p. 190). Ou seja, a salvação é uma iniciativa da Divindade e do homem para eliminação do mal. Mas a opção pela preeminência do mito adâmico que proclama o valor do homem e a santidade de Deus tem o recurso de sair dessa dicotomia insuportável?

A falibilidade é o ponto inicial para elabora uma antropologia filosófica a partir do mito adâmico. Dizer que o homem é falível é constatar que a possibilidade do mal moral está inscrita na constituição do homem. O mal procede de uma debilidade que eu coloco. Minha fragilidade possibilita a debilidade, tentação e queda. Sou castigado no momento que transgrido uma norma divina. Ao transgredir essa norma, vem sobre mim a cólera divina. $\mathrm{O}$ tema da cólera de Deus que o sofrimento evoca comprova suficientemente que não existe uma justificação racional da inocência de Deus. Todo esforço para justificar Deus se destrói sob "a opacidade do mal e a opacidade do mundo 'no qual semelhante coisa é possível"' (RICOEUR, 2013c, p. 345). Entre o pecado e o sofrimento, o trágico de Jó está um grande abismo de irracionalidade que mantém aberta a possibilidade de um Deus malvado.

Por conseguinte, uma vez que o mito adâmico exclui a solução trágico-lógica, suprime o trágico para exaltar que o mal é uma categoria dentro da lógica do Ser, Ricoeur opta por buscar o fim do trágico na Cristologia. Está é uma pressuposição claramente exprimida e que orienta o início de sua meditação sobre finitude e culpabilidade.

O mito adâmico tem em si uma tensão escatológica, uma vez que contém em si a promessa de uma realização, a salvação. Por escatologia, Ricoeur entende sendo uma doutrina capaz de incluir na própria vida de Deus, numa dialética das "pessoas" divinas, a figura do servo sofredor que evocamos como possibilidade suprema do sofrer humano. Desta maneira, o mito adâmico pode ser lido a partir dos símbolos do fim. As histórias bíblicas: Abraão, do Filho de Davi, do Servo de $Y H W H$, do Filho do Homem representam a etapa de uma originária e progressiva escatologização. É, portanto, no movimento inverso ao Fim que compreendemos o início. 
Paulo deixa claro como a Graça seja superabundante em relação ao pecado e o perdão em respeito à injustiça. Paulo em sua carta aos Romanos deixa transparecer que o perdão, supera a imagem jurídica da absolutização e do pagamento da falta pelo sentido de remissão no processo escatológico. Para o apóstolo Paulo, a justiça, que vem ao homem, é futura. Ela parte do exterior para o interior, da transcendência para o ser homem. A lógica de equivalência na qual "o salário do pecado é a morte" é superada por uma lógica da superabundância, na qual "onde habitou o pecado, aí superabundou a graça”. Essa lógica da superabundância é muito mais paradoxal que a mentalidade jurídica judaica. A partir dessa lógica é necessário ir ao extremo para alcançar a misericórdia "O salário do pecado é a morte; mas a dádiva gratuita de Deus é a vida eterna, em Cristo Jesus Nosso Senhor” (Rom 6, 23). Essa lógica da superabundância destrói o conceito de lei, como julgamento, condenação e pena. Em Paulo, há uma assimetria escatológica, uma esperança, quando diz que "a justiça de Deus se manifestou" (Rom. 3,21) e que agora existe "a justificação pela lei, sem as obras da lei”(Rom, 1, 28). Dessa forma, Paulo coloca em um evento futuro, a ruptura com o judaísmo pelo qual é sem as obras da lei que o homem é justificado, "mas agora, sem a lei, a justiça de Deus se manifestou... porque nós estimamos que o homem é justificado pela fé sem a prática da lei”( Rom. 3, 21-28). Logo o perdão é algo que supera um fato psicológico ou de uma realização dual, pois ele é um acontecimento cósmico e comunitário.

Tal como Ricoeur compreende a cristologia, ela é essencialmente uma soteriologia. Ela prolonga a linha vetero-testamentária do servo de $Y H W H$. O abismo que se abre entre Adão e Jó é aproximado pela figura do servo sofredor em Isaías. Essa figura é capaz de resolver a contradição entre o mal cometido e o mal sofrido. A figura do servo de $Y H W H$ propõe uma possibilidade de sofrimento que transforma o mal a que é submetido em uma ação capaz de redimir o mal cometido. $\mathrm{O}$ sofrimento-escândalo (pelo pecado- Adão), voluntariamente assumido e retomado como um sofrimento-dom, não mais na contemplação da criação e do consolo, mas o sofrimento, do servo sofredor, torna-se dome recebe o sentido de expiar os pecados do povo. 
Retomando no servo de $Y H W H$ o sofrimento-escândalo, o sofrimento-dom inverte a relação entre culpabilidade e sofrimento. Ele não é mais um sofrimento de punição invocado pela exigência de justiça e produzido pela falta, ele é um sofrimento fora de qualquer retribuição. $\mathrm{O}$ sofrimento insensato e escandaloso antecipa o mal humano e se encarrega de todos os pecados do mundo. É feita, assim, uma nova ligação entre sofrimento e o pecado, não mais em nível de retribuição, mas da generosidade e da misericórdia. Esse sofrimento do servo sofredor, que "faria do sofrer, do mal sofrido, uma ação capaz de redimir o mal cometido" (RICOEUR, 2013c, p. 343). A liberdade do legalismo da retribuição realiza o movimento que vai da punição à generosidade e coloca a culpabilidade em um outro nível: não o do Juízo, mas o da Misericórdia.

Seja o servo de $Y H W H$, um indivíduo ou povo, ele pertence a uma antropologia, pois ele oferece uma possibilidade extrema do sofrimento humano. Em contrapartida, "segundo a 'cristologia', esse sofrer é um momento da divindade" (RICOEUR, 2013c, p. 347). Pois, Seja qual for o sentido deste "Servo Sofredor", quer seja um personagem histórico, individual ou coletivo, ou a figura de um Salvador por vim, ele revela uma possibilidade inteiramente nova: que o sofrimento confere sentido a si mesmo, através de um consentimento voluntário, no meio do não-sentido do escândalo. $\mathrm{Na}$ visão jurídica e penal da vida, a culpabilidade tinha de ser a razão do sofrimento (...) é então que o sofrimento do "Servo Sofredor" institui um vínculo entre o sofrimento e o pecado, a um outro nível que não o da retribuição.

A figura do servo de $Y H W H$ pertence a uma simbólica da existência humana, na qual é revelada a possibilidade extrema do sofrer humano. Essa figura mostra como a razão filosófica pode aprender algo sobre a existência humana como o símbolo do servo de $Y H W H$.

$\mathrm{Na}$ cristologia existe o momento kenótico que inclui o destino em Deus, isto é, a necessidade do sofrimento do Filho do Homem. Esse destino coincide com o dom livre de sua vida pelo filho que encontra na morte a glorificação. A elevação no ser, de certa maneira, suprime o destino. $\mathrm{O}$ momento de abatimento e de aniquilação da vida divina realiza a supressão da tragédia, 
pois a desgraça está em Deus. Esse momento é ao mesmo tempo glorificação e imolação. Pois para,

a 'cristologia', esse sofrer é um momento da divindade; esse momento de abaixamento, de aniquilação da vida divina, leva à consumação e supressão da tragédia. A tragédia é consumada, por que a infelicidade está em Deus : 'Não sabíes que o Filho do Homem devia ser libertado?' Esse 'devia' exalta o destino e o inclui na vida divina (...) o devia não se compreende, nesse caso, senão à luz do 'dom' (...) destino absoluto também seja dom absoluto, eis o trágico realizado e suprimido (RICOEUR, 2013c, p. 347).

Situado em Deus, o sofrimento-escândalo assume como sofrimento-dom que não é mais uma possibilidade humana de sofrer. Essa figura do sofredor ilumina o íntimo do homem a partir do extremo do homem. Ela revela os limites do homem e, consequentemente, "uma 'Poética' da liberdade e do ser-homem que excede as possibilidades de uma antropologia filosófica" (RICOEUR, 2013, p. 346).

Essa Poética revela a esperança cristológica. De fato, a poética é criação, ou melhor, nova criação. Segundo a alegoria de Paulo no Novo Testamento, o Cristo é o segundo Adão. Nele morre o homem velho e nasce o homem novo. De um só golpe um movimento é traçado entre os dois Adões, um movimento que vai da queda à redenção, que integra a contingência do mal e reconhece o superar o trágico do mal, desse mal que sempre está-aí (RICOEUR, 1999, p. 309-310).

O homem invoca a Transcendência como aquilo que o liberta, pois faz a experiência trágica de uma auto-servidão a um mal radical que, muitas vezes, é igual e extravasa a sua responsabilidade. Essa a contradição de um mal assumido, mas sempre superior é que faz o homem se desesperar, alimentar o trágico da existência e suscitar em seu coração o desejo de justificação. Mas, para que esse mal seja abolido, faz-se necessário o integrar dentro de uma totalidade significante que respeite sua dupla característica antinômica: a contingência e a necessidade. Somente uma totalidade que confronte o mal histórico com a bondade original do ser e que retenha o trágico do mal, é susceptível de con- 
ceder o desejo de justificação que habita o homem, dando um sentido ao mal. Para Ricoeur, essa totalidade é desenvolvida em uma esperança cristã.

Toda essa simbólica bíblica dentro de uma hermenêutica, mostra uma colaboração possível entre a teologia e a filosofia, ou seja, uma dialética entre a uma filosofia moral e a doutrina da esperança cristã. Ricoeur mesmo nos diz em História e Verdade, que a relação de dependência, de inclusão que assimila toda figura histórica a um contorno nimbado de luz, só e acessível a um sentido regulador, capaz de purificar o ceticismo historizante, um sentimento que é a razão mas não saber: o sentimento de que todas as filosofias se acham finalmente na mesma verdade do ser. Ouso denominar esperança esse sentimento; é a ele que coloco sob o signo da pregação cristã é também a ele que denomino afirmação originária em Verdadeira e Falsa Angústia (quando tomo de empréstimo a M. Nabert sua admirável expressão).

Se a pregação cristã refere a esperança como um éscathon que julga e completa a história sem pertence-lhe, essa esperança de intenção escatológica causa impacto na reflexão filosófica sob a forma de um sentimento racional presente; recebo o 'penhor da esperança' quando percebo de maneira fugidia a consonância dos múltiplos sistemas filosóficos ainda que irredutíveis a um único sistema coerente. A filosofia ricoeuriana não ignora ser difícil, senão impossível superar essa mútua exclusão; entrevejo, não obstante, que é possível converter em tensão viva essa mortal contradição; viver filosoficamente a esperança cristã como razão reguladora da reflexão, pois a convicção da unidade final do verdadeiro é o próprio Espírito da Razão.

Essa esperança pode ter um terreno fecundo, se ela estiver avizinhada a um pensamento do tipo kantiano, "uma filosofia dos limites, que é ao mesmo temo uma filosofia prática de totalização (...) o fiador filosófico do kerigma da esperança" (RICOEUR, 1999, p. 402). O homem aspira sempre a bondade absoluta, mas não a pode obter por suas próprias forças. Essa bondade, diante da esperança, somente poderá ser pressuposta com a eliminação do mal radical.

É interessante notar que, para Ricoeur, o kerigma da esperança está erradicada na linguagem humana sobre o mal. Todas as outras linguagens, míticas ou da teodiceia racional, se preocupam em justificar a bondade e o poder de Deus sobre o mal, logo desprezam em suas considerações o sofrimento individual na existência humana. 
A religião em seus múltiplos desdobramentos é linguagem. Ela é expressa através de textos e narrativas, como por exemplo, do mito adâmico, bem como por intermédio de mitos e símbolos. Em Ricoeur, ainda que nunca tenha se identificado como teólogo, mas sim como filósofo, existe uma sensível articulação entre filosofia e religião, pois, a significação filosófica da religião deve ser constituída no exterior da ética. Sendo assim, a religião é uma maneira de re-descrever a realidade e o ser na como intencionalidade do sujeito mediada por símbolos, que em Ricoeur, é sempre a abertura de si no mundo.

Cabe-nos agora ver como a questão da hermenêutica, em uma linguagem poética religiosa, a partir dos textos exprime os figurativos de uma esperança. Pois é a partir dos textos, que nominamos, que referenciamos, que através da mediação textual passamos a ter uma nova condição da imaginação e condição da compreensão do sentido do ato de existir. 


\section{A linguagem religiosa portadora de uma esperança "filosófica".}

O sagrado interpela o homem, e nesta interpelação, anuncia-se como aquele que dispóe da sua existência, por que a póe absolutamente, como esforço e como desejo de existir (CI, 24).

Agora chegou o momento de mostrar como a linguagem religiosa é portadora de uma esperança como reguladora da reflexão.

O ponto de partida pelos símbolos do mal desemborca em uma reflexão sobre a linguagem religiosa. $\mathrm{O}$ símbolo tem um sentido que pode ser reapropriado por que o interpreta, ou seja, na linguagem religiosa há elementos de realidade última que somente podem ser expresso pelos símbolos. Assim, a linguagem simbólica está além do que é apreendido pela razão ou por qualquer outra forma de interpretação. Pode-se mesmo dizer que o símbolo é a linguagem mais íntima do ser. A linguagem sempre teve um caráter de construtora da realidade e estar intimamente ligada à existência humana. E se ela se liga a existência humana, logo é aquela que pode expressar através dos textos sagrados a esperança.

Esse expressar a esperança se dá através dos textos e nesses dos eventos da manifestação e proclamação, pois "é neste sentido que os símbolos estão ligados no interior do universo sagrado: os símbolos só vêm à linguagem na medida em que os próprios elementos do mundo se tornam transparentes" (RICOEUR, 1976, p.73). Transparentes na medida que sempre houve um problema hermenêutico da linguagem no cristianismo, porque ele procede de uma manifestação e de uma proclamação na qual existe uma esperança no evento da ressureição e da consumação dos tempos com o advento do Reino de Deus que se aproxima de nós. E essa narração e a sua especificidade da linguagem religiosa que narra uma acontecimento in illo tempore que me dá uma orientação temporal que carrega um acontecimento passado para um futuro cheio de esperança coroando nosso esforço de ser. 
É o nosso desejo de ser que se faz como núcleo kerygmático da ética. $\mathrm{O}$ evento do kerygma nada mais é que o testemunho que restitui ao ser humano a história do que se perdeu, ou seja, através da morte do justo, tudo está salvo.

É certo que o evento da palavra que se faz carne, um evento histórico como é a encarnação, faz com que a espera nos acontecimentos escatológicos de uma nova palavra se torne pensamento implícito de toda a ação dos símbolos, que a princípio acentua a estrutura, depois sublinha a plenitude do símbolo para enfim saudar o poder revelador da palavra originária”.

A hermenêutica dos textos sagrados nos permite fazer um encontro entre a filosofia e a teologia, contudo preservando suas distinções. Implica, ademais, uma redefinição das relações de ambas, da qual Ricoeur é testemunho em seu itinerário. Ele mesmo reconhece que sempre caminhou sobre duas pernas e por ser filósofo não estava impedido de se dedicar às questões fronteiriças entre a filosofia e a teologia (RICOEUR, 1995, p.190). Para ele, é uma relação complexa, pois a filosofia nos oferece muitas vezes respostas, como também, por vezes, a fé é que a interroga. A filosofia não é somente crítica, mas também da ordem da conviç̧ão. Por sua vez, a convicção religiosa tem uma dimensão de crítica interna.

Não podemos, mesmo diante das aproximações entre a teologia e a filosofia, esquecer da diferença entre um discurso que vive do dado da fé e que proporciona uma palavra que regenera o mais profundo do ser; e um discurso que deixa em suspenso a nominação de Deus. $\mathrm{O}$ modo diverso que assume a teologia e a filosofia, na linguagem figurativa e na linguagem conceitual, tem equivalente prático nas relações entre a lógica do dom e a lógica de equivalência, entre o poético e o ético, entre fenomenologia e manifestação/proclamação, entre hermenêutica teológica e hermenêutica filosófica. O certo é que, as duas são ouvintes, a teologia ouvinte da pregação cristã, a filosofia ouvinte de uma palavra anterior a própria reflexão, de que esta depende, pois "admitir-se ouvinte, é, logo de início, romper com o projeto caro a determinados filósofos - talvez a todo filósofo - de começar o discurso sem pressuposições” (RICOEUR, 1996, p. 281), pois todo discurso é um acontecimento e a leitura (de um texto, de uma obra) é um novo acontecimento de discurso que é a própria intepretação. 
Dito isso, uma reflexão filosófica que pretenda iniciar sua reflexão do zero, que pretenda iniciar a partir de si, sem pressupostos, não é menos dependente que uma teologia que se encerra em uma Palavra anterior que não the pertence. Contudo, uma filosofia que pretenda começar a partir das verdades que reflexiona, a partir de pontos de intersecções é uma filosofia hermenêutica, que não é tomada sem pressupostos, mas que parte para assumir todos os pressupostos. Assim, Ricoeur mira a linguagem religiosa para ser articulada no ambiente de confronto de interpretações.

\subsection{O símbolo como ponto de partida da reflexão sobre linguagem religiosa}

O símbolo agrado é o ponto de partida para a reflexão da hermenêutica de Paul Ricoeur conforme vimos no primeiro capítulo. Existe uma grande variedade de símbolos, mas o símbolo sagrado permite expressar a experiência do mal como um momento necessário à reflexão:

Efetivamente é através dos mitos que eu digo qualquer coisa que não se reduz à dominação da natureza, ao nomear e que não pertence a uma linguagem utilitária; esse dizer é significativo através da relação do homem com o outro, com todas as coisas, com o ser. Existe, portanto, um mundo da "representação". A representação, para Hegel, são todas as figuras. Existe um mundo de figuras que dá a pensar (RICOEUR, 2013, p.67).

A fenomenologia de Hegel não conduz a uma escatologia. O que ela pretende é um saber absoluto e não a fé. Para se introduzir uma fenomenologia do sagrado é necessário questionar esse saber absoluto. É justamente aí que a reflexão percebe seu limite e percebe o mal e dessa forma abre o espaço ao sagrado. O símbolo do mal nos mostra a realidade limitada e deficiente da existência humana. O mal nos mostra que mesmo diante da filosofia ele é injustificável, inescrutável. Os símbolos do mal nos apontam para uma salvação que pode e deve ser esperada em um horizonte de apesar do mal. Esse apesar é a esperança na qual graças a um kerygma.

Pode-se dizer que o procedimento hermenêutico de Ricoeur, no confronto dos mitos e da linguagem religiosa, compreende três etapas: da semânti- 
ca, da reflexão e da ontologia. Seguindo essas três etapas, nosso filósofo mostra que o Sagrado radicaliza e faz com que o onírico e o poético sejam identificados. Assim é “a razão por que é necessário sempre que morra o ídolo a fim de que viva o símbolo(...) Se o Todo-Outro se aproxima, é nos signos do sagrado que o faz" (RICOEUR, 1977, p. 425).

O Sagrado coloca o homem em relação de deslocar o centro do sentido para a Transcendência. Nisso opera-se o que Ricoeur chama da segunda revolução copernicana, transferindo o centro do sentido do Cogito à Transcendência.

Primeiramente, o filósofo francês esclarece três traços fundamentais para uma fenomenologia do sagrado. Nesses três traços ele mostra que a fenomenologia não se explica, mas se descreve. Explicar significa relacionar o fenômeno religioso ao seu objeto, assim como é proposto e dado na sua manifestação.

Para a fenomenologia da religião há uma "verdade" do símbolo, ou seja, há um cumprimento da intenção significante. Ou seja, para a fenomenologia da religião não existem signos puros que associamos arbitrária e convencionalmente com o significante e significado, mas os símbolos dizem algo sobre a realidade que eles significam e que se manifesta graças à função significante. Assim, os símbolos estão sempre plenos da realidade.

A fenomenologia da religião conserva a capacidade ontológica dos símbolos do Sagrado, já que para aquela os símbolos são como uma palavra do ser. Ou seja, expressão do ser que forma o homem. De fato, não é tanto o homem que forma a linguagem, quanto é o homem que nasce na e pela linguagem.

Através dos símbolos, o homem se descobre a si mesmo no universo de sentido, em um Logos que forma o próprio homem. Por isso, a fenomenologia da religião é a da reminiscência. A psicanálise, ao invés, fala do retorno do remorso.

Paul Ricoeur é um desses pensadores, na história da filosofia, que pode nos introduzir a uma leitura de temas de fontes não filosóficas da filosofia, como é o caso dos textos sagrados da Bíblia que trazem termos como: Deus, Revelação, Testemunho, pecado, mal... Ou seja, de incursionar nas fronteiras da filosofia, não de uma forma que se perca o norte, senão por uma peregrinação deliberada de quem sabe que a menor distância de si a si é o outro. Essa é 
a razão que o anima a explorar a fundo as questões tão diversas como a fenomenologia da religião, psicanálise e linguagem metafórica.

O filósofo não pode silenciar sobre o fenômeno religioso, pois nele está presente o problema e a solução para o homem: o início, o fim, o mal, a salvação. Esses problemas são dados indiretamente, em uma linguagem simbólica na qual não existe somente um valor expressivo, mas sim um valor exploratório que o homem não pode conhecer nem exprimir. Ricoeur, então, enfatiza que o símbolo do mal é o campo mais significante e o lugar do nascimento do problema hermenêutico.

A reflexão hermenêutica de Ricoeur é posta na fenomenologia do sagrado em um contexto reflexivo, enquanto se trata de refazer a experiência simbólica, não mais na espontaneidade em que nasceu, mas em uma crítica. Ela se forma acolhendo a linguagem simbólica como uma linguagem estranha, complexa, de duplo sentido. Todavia, ela tem a capacidade de exprimir e comunicar, simbolicamente, a experiência desmedida e complexa da confissão da culpa ou da manifestação do sagrado.

O desenvolvimento da experiência do mal corresponde a um desenvolvimento da linguagem simbólica através da linguagem figurativa e indireta, pois "a consciência de si parece constitui-se em profundidade por meio do simbolismo e só elabora uma língua abstrata em segunda instância, através de uma hermenêutica espontânea dos símbolos primários” (RICOEUR, 2013c, p.25), por meio dos mitos.

Como foi visto no capítulo anterior, é através da análise fenomenológica do símbolo do mal que é obtido o conceito de servo-arbítrio para o qual tende todo o grupo dos símbolos primários do mal. Todavia, esse conceito não é acessível de forma direta, pois se se quer determinar um objeto ao qual isso corresponda, irá eliminar ou a servidão ou o arbítrio. Esse conceito é um conceito indireto e resulta do caminho que vai do símbolo à reflexão. É um conceito paradoxal, para o qual tendem os símbolos primários do mal. Por isso é um conceito indireto que não recorre a uma simbólica anterior. Logo, não haverá outra maneira de nos aproximarmos desse conceito, se não for através da mediação de símbolos de segundo grau, a partir do mito do mal. 
O que interessa no conceito de servo-arbítrio não pode ser representado como falibilidade, nem se identifica com isso. Ele só pode ser visado como uma Ideia, um telos intencional de toda a simbólica do mal, que constrói uma relação circular nos símbolos. Esse telos desenvolve o sentido do símbolo mais arcaico sem reduzi-lo ou limitar a sua eficácia. Desta forma, sempre se retorna aos símbolos arcaicos que não se deixam sistematizar, pois esses manifestam uma situação que se concentra na relação do si consigo mesmo.

O conceito de servo-arbítrio diz que o mal é algo de positivo, exterior à liberdade humana e algo que infecta o homem. Por isso, o mal é, também, algo que deriva de uma má escolha, provinda do coração do homem e, consequentemente, é uma autoinfecção.

Em se tratando do mito, como vimos, a análise ricoeuriana chega a mostrar que o mal é um já-aí, um fruto da escolha livre e de algo que se impõe ao homem, uma visão trágica, órfica do mal. Esses aspectos do mal formam uma circularidade no universo do mito, assim como é feito no universo dos símbolos primários.

Para Ricoeur, o mito adâmico é o mais exemplar para explicar essas situações graças à "sua complexidade e às suas tensões internas, [que] reafirmam em graus variáveis o essencial dos outros mitos" (RICOEUR, 2013c, p. 328). Assim, ocorre uma relação de oposição e de identificação entre os mitos, segundo uma perspectiva em relação ao mito dominante. Logo, a conclusão desse trabalho fenomenológico é a afirmação que "o universo dos mitos permanece um universo quebrado" (RICOEUR, 2013, p. 363). A partir disso se opõem duas possibilidades e uma constatação. $\mathrm{Ou}$ se unificam os mitos a partir de um deles, ou se busca compreendê-los na imaginação e na simpatia, sem uma apropriação pessoal. A constatação é que dos símbolos e dos mitos vem anunciada uma dimensão hiper-ética que indica o limite da filosofia da vontade que sempre está dentro de uma visão ética do mundo.

O resultado dessa especulação, aplicada aos mitos que fazem referência à entrada do mal no mundo, condena uma especulação semelhante, mas diz algo a respeito do resultado da fenomenologia da vontade e, por conseguinte, requer que a filosofia se pronuncie a respeito. 
É notório que a análise fenomenológica de Ricoeur sobre os mitos parte do pressuposto que ao considerá-los e estudá-los, afirma-se a preeminência do mito adâmico.

Através da fenomenologia da religião se percebe que a vontade é ao mesmo tempo livre e serva no mundo, exigindo, assim, uma compreensão filosófica. O problema que surge, então, é que a fenomenologia finda com a reminiscência do sagrado, no sentido de uma ontologia do símbolo, pelo qual revela a situação do homem no mundo.

Ricoeur põe o sagrado no posto de um "saber absoluto", pois a significação do sagrado é escatológica, ou seja, não mais transformada em conhecimento, etiologia ou em gnose. Os símbolos do sagrado resistem ser reduzido a um conhecimento racional e, desta forma, não podem ser antecipados. Pois, “o símbolo é o próprio movimento do sentido primário que nos faz participar no sentido latente e assim nos assimila ao simbolizado, sem que possamos dominar intelectualmente a similitude" (RICOEUR, 1999, p.285).

O símbolo tem seu valor inesgotável de significado, eles reúnem o que o conceito quer dar sentido, ou seja, os símbolos

reúnem em um mesmo núcleo de presença uma massa de intenções significativas que, antes de se darem que pensar; dão que falar; a manifestação simbólica como coisa é uma matriz de significações simbólica como palavras; dizer o céu manifesta o sagrado e que ele significa o Altíssimo (...) tudo isso é dizer uma e a mesma coisa; a manifestação é como uma condensação de um discurso infinito (RICOEUR, 2013c, p. 27).

O símbolo, assim, tem uma dupla função: de ausência, pois diz coisas sem as coisas e de presença, pois sempre significa algo, diz um sentido distante. Os símbolos, desta forma, falam de uma forma mais profunda do ser humano e de sua existência.

A experiência do mal é uma posição mistificadora que subtrai o homem da realidade para fechá-lo na nulidade de sua imagem. O discurso filosófico não tem uma conclusão sobre o mal e recorre aos mitos para expressar o que há de mais radical. Diferentemente do mal, o sagrado sempre 
abre o homem para a superação, pois os símbolos do sagrado são sempre para além da figura do espírito em uma esperança. Tais figuras são exigidas pelo sagrado para que possa ser expresso.

O sentido e a coerência do sagrado vêm em busca não de uma lógica do ser, mas de uma história sensata que, contudo, não consegue exaurir o sagrado. Dessa forma, os símbolos do sagrado "são a profecia da consciência, manifestando a dependência do si de uma raiz absoluta da existência, de significado, um eschaton, de um último, que apontam em direção a figura do espírito" (RICOEUR, 1999, p. 327).

Entretanto, se a pregação cristã refere a esperança a um eschaton que julga e completa a história sem pertencer-lhe, essa esperança de intenção escatológica causa impacto na reflexão filosófica sob a forma de um sentimento racional presente; recebo o 'penhor da esperança' quando percebo de maneira fugidia a consonância dos múltiplos sistemas filosóficos ainda que irredutíveis a um único sistema coerente" (RICOEUR, 1968, p. 11).

Essa citação possibilita uma articulação entre esperança e escatologia. Ainda mais, ela confirma a reflexão do homem a partir da finitude, pois embora se afirme que a esperança se refere a um eschaton, se refere a um plano que não concerne a um desenrolar histórico; existe uma consonância dos discursos filosóficos, mas de modo muito tênue e quando reitera a não possibilidade de reduzir os discursos filosóficos a um único discurso unificador.

O problema hermenêutico se põe como um problema de como apreender a dupla dependência do $s i$ sobre o inconsciente e sobre o sagrado a partir dos símbolos que a manifestam, mesmo quando essa se manifesta somente de modo simbólico. Deste modo, a reflexão deve incluir o duplo movimento arqueológico-teleológico. Arqueológico, no sentido de voltar-se para o passar, mas vislumbrando um futuro, ou seja, aspirando além de nós, com esperança, para transformar a nossa existência. Teleológica, pois a origem do mal suscita uma questão de escolha, pois o homem está, ou se descobre envolvido no mundo da ética. Todo esse "trabalho é comparado a uma aspiral sem fim, sempre recomeçada e ampliada, orientando o enraizamento arqueológico ainda in- 
consciente. Num devir teleológico para uma inserção voluntária e emancipadora” (RICOEUR, 1999, III).

Em Ricoeur, é necessário um ulterior progresso do pensamento, um ponto de vista estritamente filosófico, no qual, "somente um sujeito que tem um telos tem um arche” (RICOEUR, 1977, p. 432). É um exigência necessária para a filosofia reflexiva colocar o conceito de arqueologia (uma exploração de tudo o que, no sujeito, é em relação com o principio e com o anterior, não somente em sentindo temporal, mas no sentindo de insuperabilidade), em relação ao de teleologia, a filosofia reflexiva, dessa forma, adere a tarefa de superar a própria abstração inicial.

Ricoeur mostra que existem três fontes de sentido. A primeira fonte de sentido a que a hermenêutica reflexiva de Ricoeur se encaminha é o desejo. Esse não pode ser mais esgotado pela reflexão, mas é impulsionada em direção à linguagem, que é sempre simbólica.

Uma segunda fonte de sentido é a imaginação poética. Ela constitui o poder de evocação do possível e os mitos evocam o possível como originário, como o último e como espírito. Contudo, a imaginação dá ao homem uma figura possível, mas é a razão que exige a felicidade e é a sensibilidade que atesta essa possibilidade. Desta forma, a imaginação da felicidade é intermediária entre a razão e a sensibilidade. Todavia, a imaginação do homem é verdadeiramente criadora, seja no sentido que cria uma nova possibilidade, seja no sentido que ela fornece a energia necessária para realizá-la. Assim, a imaginação é livre.

Contudo, é interessante lembrar que o homem não cria nada do nada, mas simplesmente abre novas possibilidades no interior e uma matéria infinitamente mais rica de intenção que formam os símbolos. Desta maneira, para encontrar o sentido dos símbolos deve-se recorrer à sensibilidade e ao rol de jogos da estrutura da linguagem, pois "é na linguagem que o cosmos, o desejo, o imaginário tem acesso a expressão; é sempre preciso uma palavra para recuperar o mundo e fazer com que ele se torne hierofania" (RICOEUR, 1999, p. 15).

A terceira e última fonte de sentido é a que se refere ao sagrado e à dimensão do símbolo que opera a descentralização mais radical do Cogito. Nos outros dois casos, os símbolos falam sobre o desejo e a aspiração es- 
condida do homem. Eles têm como função um duplo sentido, cujo papel é desvelar e velar. A hermenêutica tem seu campo nos símbolos, onde um sentido direto assinala um sentido indireto e mais rico. A hermenêutica, portanto, tem por tarefa interpretar o sentido velado do sentido manifesto, através da pluralidade de sentidos e do valor polissêmico das palavras. $\mathrm{O}$ símbolo tem por função mostrar a experiência, um uma região humana da experiência humana, que de outra forma ficaria velada.

No simbolismo sagrado o homem fala sobre a própria natureza, que se torna uma nova fonte de significação. $\mathrm{O}$ cosmos somente pode se exprimir em uma linguagem com duplo sentido. Isso é conjunção entre o orgânico e o psíquico, pois o homem comunica e participa intimamente do cosmos.

Através da natureza que se torna palavra, o homem descobre um surplus (excesso) de significado pelo qual ele reconhece uma manifestação do divino. Ricoeur crê profundamente que a linguagem dos símbolos seja mais falada aos homens que falada pelos homens. O homem é nascido na linguagem, que se dá através da luz do logos. Esse ato coloca a filosofia em condição de fazer da Transcendência o centro de sentido que o homem não cria, mas acolhe. Ricoeur faz uma aposta pelos símbolos, ou seja, compreender melhor o homem seguindo as indicações que os símbolos nos dão.

Essa etapa é atravessada pela dificuldade do conflito das interpretações. Ademais, essa etapa rende à aposta um caráter inteligível e promove uma dedução transcendental do símbolo e do sujeito, que são verificados existencialmente, a partir do novo campo de experiência aberto ao próprio símbolo.

O problema é então saber que valor ontológico resulta da etapa reflexiva que leva o sujeito, a ser compreendido como tarefa e não mais como dado, mas que provocou a necessidade de voltar-se ao ser, que é manifesto e nascido do símbolo. Sublinha-se que o ser vem sempre alcançado pelo Cogito, considerado não mais como um sujeito oposto ao objeto, mas inserido no interior do ser do qual participa.

Ricoeur coloca que a questão da identidade do sujeito é oposta ao sentido da identidade da pessoa concreta. A identidade entendida por Descartes é uma identidade a-histórica do eu que foge à alternativa da permanência e das modificações temporais, pois o Cogito é instantâneo. 
A certeza do Cogito é apenas de caráter subjetivo, uma vez que o gênio maligno não assegura uma certeza objetiva, que acontece somente no interior do cogito, isto é, para um eu fechado em si próprio. Quando o Cogito se coloca subordinado à verdade divina que é a primeira, segundo a verdade da coisa, ele seria verdadeiramente absoluto em todos os aspectos. Porém Ricoeur diz que a ideia de mim mesmo aparece profundamente transformada pelo solo feito do reconhecimento desse Outro que causa a presença em mim de sua própria representação. O cogito escorrega para o segundo plano ontológico. Assim, o Cogito tem valor de fundamento e é uma verdade vazia, pois é preciso reencontrar o eu do eu Cogito através da reflexão sobre a obra e sobre os atos do Cogito porque não há intuição direta disso. Essa reflexão é mais uma intepretação, uma vez que a obra do Cogito é expressa ao mostrar um surplus de significado e uma estrutura de duplo de sentido, onde um é transmitido pela regra estrutural independente do sujeito e outro dependente do sujeito.

Esse duplo sentido vai em direção ao sentido oculto, inevitavelmente, através do sentido primário. Por conseguinte, a reflexão encontra um Cogito que se esforça para existir em um mundo e na abertura à Transcendência, que é o centro último do sentido.

A reflexão, deste modo, não é simplesmente uma crítica da consciência, que busca o que é a priori e o que é empírico na consciência para justificar a operação do pensamento que funda a objetividade da nossa representação. Aliás, ela é uma reapropriação do nosso esforço por existir que se move na polaridade hermenêutica na qual a epistemologia é só uma parte.

Ao dizer reapropriação, quer-se mostrar que a situação inicial de que a reflexão parte, daquele esquecimento do eu nos objetos e na obra, é a de restauração o $e u$. Por isso a filosofia é ética, porque busca o eu no esforço para existir e no desejo de ser. Esforço e desejo testemunham a obra do $e u$. Enquanto o eu é desejo, ou seja, não é uma memória pura, mas uma criação e uma liberdade. Ricoeur se encontra entre memória e liberdade, arqueologia e teleologia.

Sobre a etapa reflexiva pode-se dizer que a psicanálise não é uma ciência da observação, mas uma disciplina interpretante enquanto busca o seu objeto. Não através de uma observação direta, mas através de uma decodificação, um 
trabalho de desmascaramento. Os resultados da psicanálise não tendem para o domínio do objeto da psicanálise, mas a verdade e a saída da consciência de si mesmo, mediante a referência do sentido a um "tópico" e a uma "energia” não percebida pelo sujeito. A psicanálise, assim, chega ao sentido e ao desmascaramento da certeza do sujeito como ilusão. Tudo isso graças a um trabalho interpretativo apropriado ao trabalho de distorção no ato do sonho. Esse sentido é constituído de um fundo arqueológico do sujeito, deduzido transcendentalmente, que se revela como desejo subjacente e operante em cada expressão. A psicanálise, consequentemente, descobre a existência como desejo, que não é reduzido à consciência que o sujeito tem.

Pode-se dizer que na fenomenologia do espírito, ao invés, transfere a origem do sentido em uma direção teleológica para a figura seguinte e não mais para a precedente. Isso determina o fato de que a consciência é arrastada fora de si para um sentido que está em movimento e que em cada fase é retida e abolida na seguinte.

A Fenomenologia da religião se coloca, de certa maneira, ao nível ontológico do espírito. Descreve a forma de linguagem e de sentir através do qual o homem se põe como objeto do sagrado. Nesse o homem opera a mais radical desapropriação de si, pois nele já existem duas interpretações, a arché e o telos, que são disponíveis ao homem.

O sagrado interpela o homem como aquele "que dispõe de sua existência, porque a põe absolutamente, como esforço e como desejo de ser" (RICOEUR, 1999, p. 24). O sagrado diz que a existência do homem é radicada na transcendência, nunca objetivável e nem disponível, que está sempre aberta sobre o paradoxo e a esperança.

A esperança em Ricoeur é um ponto de saída e o horizonte de cumprimento da filosofia. Dessa maneira, faz-se necessário examinar a linguagem religiosa trabalhada por Ricoeur, a fim de saber se a hermenêutica da linguagem poética e do testemunho fornecem uma base suficiente para pensar uma hermenêutica da esperança contida nos textos sagrados e qual é tarefa da hermenêutica filosófica diante desses textos sagrados. Pois, 
Antes de abordarmos propriamente o recurso a linguagem religiosa como algo que redescreve a realidade e pode nos falar da esperança nos textos sacros. Cabe fazer uma distinção entre a fé e a religião. Isso porque, Ricoeur, não vai da filosofia à Teologia, ou vice e versa, sem que delimite, por causa de seu método filosófico, ao seu leitor o que lerá. Desse modo, essa distinção permite a Ricoeur um novo modo de pensar. Sem que o ato do filosofar seja impedido pela conivência religiosa e seu dogmatismo.

\section{A Fé e a Religião}

Em Ricoeur não vemos a intenção de transferir o peso do símbolo, como aquilo que dá a pensar, ao símbolo religioso, puramente, pois a filosofia reflexiva afugenta a possibilidade de acolher a problemática da fé. Ela tem origem no Totalmente Outro, de forma que distancia a nossa compreensão, ou qualquer tentativa que o queira englobar em um saber absoluto. Entretanto, esse Totalmente Outro, faz parte do nosso mundo e é manifesto através do evento da palavra humana. Logo, o problema da fé é um problema hermenêutico. Isto é, a fé sempre é um horizonte, como "metáfora do que se aproxima sem jamais tornar-se objeto possuído" (RICOEUR, 1977, 421), do nosso saber. Existe um motivo que impende a fé ser um saber absoluto e vice-versa, pois a razão não pode produzir por si o sentido que se revela na fé. Esse motivo é o mal, que é o fracasso radical de cada saber absoluto. Somente em fenomenologia do sagrado, que aponte para uma esperança, como manifestação da nossa existência e nosso esforço por existir, pode substituir a reflexão e "oferecer a um pensamento que medita novas expressões simbólicas, situadas no ponto de ruptura e de sutura entre o Todo-Outro e o nosso discurso" a despeito do mal, constituindo-se sobre a esperança escatológica.

A fé é definida negativamente pela sua diferença da religião, que nada mais é que a ilusão da fé, a sua impossibilidade de objetivação. Em Barth, a religião é a relação que parte do homem para chegar a Deus, no qual o sagrado torna-se ídolo, objeto possuído pelo homem e escravo dele. Ao contrário do que Barth diz, a fé é a relação que parte de Deus para chegar ao homem. A sua origem não é o homem que objetiva, mas o Totalmente-Outro que se manifesta pela palavra. 
Há, para Ricoeur, a necessidade de distinguir a fé da religião, de forma que, “jamais cessamos de separar a fé da religião, a fé no Todo-Outro que se aproxima, da crença no objeto religioso que vem acrescentar-se aos objetos de nossa cultura, integrando dessa maneira nossa esfera de pertinência” (RICOEUR, 1977, p. 423). Contudo, fé e religião estão ligadas pelo simbolismo sagrado. Logo a fé "é região da simbólica onde a função de horizonte não cessa de decair à função de objeto, dado origem aos ídolos” (RICOEUR, 1977, p. 423).

Consequentemente, a problemática da fé implica em uma hermenêutica da desmistificação. É interessante notar, que a crítica que se possa fazer a psicanálise, refere-se unicamente a religião e a metafisica, conforme podemos ver em: Freud, Marx e Nietzsche. Claro que o confronto entre a psicanálise e a religião mostra que aquela não pode pronunciar um juízo último ou definitivo sobre a legitimidade da fé. Ela está aberta a possibilidade da fé e da não fé, pois a ultrapassa o limite de sua competência.

\section{O recurso à linguagem religiosa}

O homem para exprimir a confissão do mal praticado necessita de uma linguagem que supera a função descritiva, seja aquela objetiva, seja emocional. Essa linguagem é a da metáfora, que propõe uma verdade metafórica constituída sobre a estrutura de sentido, próprio como o símbolo. $\mathrm{O}$ problema do mal conduziu Ricoeur a perceber que a linguagem simbólica tem muito em comum com a linguagem poética.

Ricoeur procura articular a relação entre realidade e linguagem. Não é que tudo seja linguagem, como às vezes se diz, com excesso, em concepções em que a linguagem perdeu a sua referência ao mundo da vida, ao da ação e ao do comércio entre as pessoas. Mas, se nem tudo é linguagem, tudo na experiência, só tem acesso ao sentido sob a condição de ser trazido à linguagem. A expressão trazer a experiência para a linguagem convida a considerar o homem falante senão como o equivalente do homem, ao menos como a condição primeira do ser-homem. Mesmo se, em um momento, fossemos levados a fazer da categoria do agir a categoria mais eminente da condição pessoal, o agir propriamente 
humano se distinguiria do comportamento animal, e, como maior razão ainda, do movimento físico, pelo fato de que ele deve ser dito, isto é, trazido para a linguagem, para ser significante.

Entretanto, cabe-nos uma indagação: em que pontos a linguagem bíblica, religiosa é e não é uma linguagem poética? Ricoeur nos diz que "como a revelação, no sentido religioso do termo, se liga ao poder revelador de cada linguagem poética, capaz da verdade metafórica [...] a pretensão à verdade das expressões religiosas [...] não é um simples corolário de uma teoria da verdade metafórica” (RICOEUR, 2015, prefácio). A abertura que a linguagem religiosa tem e que é caracterizada pelo trabalho poético de suas significações é que pode nos mostrar como ela é mediação entre o mundo e a transcendência, ou seja, essa mediação é a esperança que a linguagem esboça. Cabe, então, ao filósofo refletir as antimonias entre fé e religião, até encontrar o nível de questionamento que torne possível uma mediação entre as duas.

A verdade metafórica é a condição necessária, mas não suficiente da dimensão da linguagem religiosa. Todavia, onde reside essa dimensão veritativa? Em parte, a pergunta já foi respondida pela citação acima. Ou seja, não depende somente da dimensão veritativa da linguagem religiosa, mas também da eficácia social da fé religiosa, pois "a tarefa de uma hermenêutica é, então, de criar de modo satisfatório as duas empresas” (RICOEUR, 1999,XVI).

A superação da oposição entre linguagem poética e religiosa dá a Ricoeur a possibilidade de ter uma base que acolha a Palavra de Deus na palavra do homem. A alteridade e a gratuidade da palavra de Deus são a garantia que a linguagem poética não somente proclama, mas também manifesta, ou seja, revela o horizonte originário de nosso ser no mundo.

Essa linguagem oferece a garantia de acolhimento da Revelação como palavra inacessível e faz com que o homem decida por essa como um dom gratuito. Ela "redescreve" a realidade, mas a escutando por meio de uma linguagem metafórica e dos símbolos. Esse "redescrever" nos ajuda a evitar a ilusão de uma linguagem ou de um significado absoluto.

A linguagem religiosa revela precisamente a dimensão fundamental do ser humano, o escutar. Ele se faz silêncio para receber a nossa imersão no ser. 
A linguagem poética revela os limites da razão e Ricoeur se dispõe estudar a linguagem religiosa a partir desses limites.

Diante do exposto, cabe-nos apurar em que consiste a especificidade da linguagem religiosa, pela qual pode se exprimir a esperança, no confronto com a poética. Veremos que a teoria da verdade metafórica é a condição necessária, mas não suficiente para reconhecermos a dimensão veritativa da linguagem religiosa. Dessa forma o problema da relação entre a poética e a hermenêutica teológica, dado o paralelismo do esquema entre Cogito-hermenêutica-Cogito, é posto.

Existe aí, no paralelismo supracitado, uma lógica interna que obedece a um esquema sistemático que é oportuno para a compreensão da linguagem religiosa. Esse esquema se compromete a desenvolver o histórico da reflexão em Ricoeur no que tange a linguagem religiosa em vista de expressar a esperança que está contida nos textos sagrados do Antigo e do Novo Testamento. A hermenêutica dos textos bíblicos vai permitir explicitar a mediação de linguagem pela qual se exprimem os figurativos da esperança.

O ponto de partida é a linguagem religiosa, lugar hermeneuticamente privilegiado para uma compreensão do que diz respeito a Deus, pois "o primeiro gênero de discurso no qual os escritores bíblicos tentaram falar de Deus é a Narração" (RICOEUR , 1999, p. 473). Isso revelará um ponto em comum entre a poética e a especificidade da linguagem religiosa enquanto podem exprimir a esperança. Proceder-se-á um confronto entre hermenêutica filosófica e bíblica. Esse confronto mostrará que entre as duas a poética é posta como elemento intermediário, necessário e suficiente para mostrar a esperança contida nos textos sagrados.

Ao analisar os símbolos, Ricoeur descobre uma estrutura ontológica que pode ser separada dos símbolos e que tem como centro a relação dialética entre evento e sentido. Essa relação é aquela do círculo hermenêutico que se exprime na linguagem poética, mesmo não o reduzindo. Ricoeur afirma que é uma base pré-linguística de cada linguagem que não se deixa exprimir.

Essa base pré-linguística é o ser em ato, como potência de existir que corresponde no homem ao esforço de existir e na linguagem a criatividade poética. Diante desse ser, no qual o homem participa, a razão mostra os seus limites, 
que estão associados ao fato de que essa se aplica às figuras, isto é, ao mundo organizado, para interpelar e buscar as estruturas. Porém, não para criá-las ou produzi-las. Esta é a tarefa da imaginação que se serve do esquema racional, mas para transformá-las e projetar um novo modo possível de ser no mundo.

Ricoeur afirma que uma arqueologia do sujeito e uma teleologia do sujeito, que se baseia sob a ontologia da desproporção, são insuficientes para explicar a dialética do evento e do sentido. Assim, ele coloca o problema de se recorrer à escatologia do sujeito. Desta forma, as expressões religiosas que as manifestaram colocam ao homem uma questão: esperar na transcendência ou cair no desespero da imanência.

São vários os motivos para se recorrer à linguagem religiosa na busca de uma escatologia do sujeito e a uma participação na unidade religiosas do ser. Primeiramente, a afirmação originária como negação é desproporcionalmente constitutiva no homem e a conciliação com a Transcendência somente pode ser esperada e não necessária.

A afirmação originária é um tema eminentemente ontológico, que marca a influência de Nabert sobre Ricoeur. É o termo chave em Verdadeira e Falsa angústia de 1953. Esse artigo reflete sobre a angústia do tempo presente. São cinco tipos de angústia que o artigo descreve: a angústia vital, perante a contingência da vida, a possibilidade de morrer; a psíquica, perante a fragilidade do psiquismo, a possibilidade de loucura e alienação; a histórica, ante a ambiguidade da história e a possibilidade de seu sem sentido; de culpabilidade, ante o nada de uma liberdade escrava e, portanto, a possibilidade da culpa, de degradar-me enquanto possibilidade de ser livre e, a angústia diante da possibilidade de um Deus mal, de um fundamento mal. Essa angústia envolve todas as demais, pois se o fundamento é mal, pode o mesmo fazer cair sobre o homem a culpa e é possível que a história não tenha sentido. Segundo Ricoeur, revelam em seu fundo a afirmação originária, a raiz dos atos. Essa veemência existencial que a angústia põe em crise é mais originária que qualquer angústia que possui origens mais profundas.

O problema da angústia, ao nível da reflexão, suscita o problema da liberdade: angústia da escolha e da culpa. A negatividade da angústia pode ser 
assumida no interior de uma filosofia da liberdade de uma maneira existencial, pois a liberdade é de modo indiviso angústia e soerguimento, angústia de perder, de sair de si mesmo, sem apoio nem garantia, $e$ irrompe de projeto, abertura de porvir e posição de história. A angústia torna-se o sinal de uma liberdade, que descobre em si mesmo como potência do pecado: uma liberdade perdida e exposta a um ser angustiado, pois a culpa é a escravidão do nada.

A reflexão pode descobrir uma angústia autêntica, que encontra sua justificação na reflexão kantiana sobre o mal radical: além do mal empírico, este mal é um mal radical que não tem uma fundamentação teórica e que é inescrutável. $\mathrm{Na}$ angústia metafisica, último degrau que abre para a angústia existencial, não é permitida a esperança. Nessa angústia, o homem acolhe não ser somente o autor do mal, mas vítima, pois o mal o precede, o supera e o enlaça. Nesse ponto, somente um ato de esperança torna capaz de afrontar a angústia: uma esperança escatológica e doada, para qual o tempo presente caminha ainda acompanhado pela angústia. Logo, meditar sobre a angústia é explorar e assumir "a afirmação originária, mais originária que qualquer angústia supostamente original" (RICOEUR, 2013c, p.294).

$\mathrm{O}$ único ato que pode responder à angústia é a esperança. Ela tem o poder de ir recapitulando todos os graus da afirmação originária e de animar o eu profundo em sua luta com todos os níveis da angústia, entretanto ela não é um saber absoluto, a afirmação originária, armada com a esperança, não opera nenhuma anulação, negação (Aufhebung) tranquilizadora; ela não "supera", mas "enfrenta"; não reconcilia mas consola; eis por que a angústia a acompanhará até o último dia.

O homem, em sua finitude, tem motivos para esperar e consentir. A esperança se baseia no ato no o qual homem espera algo mais de outro. Esse algo mais resulta da espera que o mundo seja uma analogia da Transcendência e, desta maneira, possa ser admirado. Contudo, isso depende da esperança, pois a Transcendência não é o mundo, não é algo de objetivo, mas sempre é algo além. A esperança precisa que o homem aceite sua condição finita como penhor e símbolo da Transcendência. Se a esperança é a alma do consentimento, é o consentimento que lhe dá um corpo. Esperança não é ilusão. A fuga para cima não seria um ponto finalmente diferente de recusa e desdém. A espe- 
rança que deseja a libertação é o consentimento que se esforça em suportar os sofrimentos. A paciência imanente - essa que permanece em jogo - é a figura da esperança que transcende. Assim, a esperança não é o ponto triunfal do dualismo, mas o viático a caminho da reconciliação.

O homem tem uma liberdade finita, ou seja, uma liberdade criadora, motivada, incarnada e contingente. Ricoeur diz que essa liberdade é "à imagem do absoluto por sua autodeterminação idêntica ao seu poder de se determinar a si mesma, mas diferente do absoluto por sua receptividade" (RICOEUR, 2013c, p. 455).

Para Ricoeur, Deus é a ideia-limite que se sobrepõe à liberdade humana, que é recíproca de um involuntário. Sendo assim, Deus não sai de uma descrição da subjetividade, pois "uma verdadeira Transcendência é mais que uma ideia limite, é uma presença que inaugura uma verdadeira virada na teoria da subjetividade; essa introduz uma dimensão radicalmente nova, a dimensão poética” (RICOEUR, 2013c, p. 456).

Podemos dizer, mais claramente, que o homem espera quando consegue imaginar e aceitar como possível por si a necessidade que o constitui no mundo que Deus lhe deu. De tal modo, se abre para o homem a possibilidade de um mundo transfigurado, de um mundo reconciliado, no qual ele devesse se reconhecer. Esse mundo exige, por um lado, uma aposta, um certo risco, pois o homem, com razão, descobre a contingência. Por outro lado, emerge uma linguagem mítica que supere os limites da razão sem desprezá-la.

O recurso a linguagem religiosa é ligado ao fato de que o homem deve pôr o problema da verdade de cada linguagem que encontra. Não só para dar sentido, mas para verificar a veracidade. O filósofo, assim, deve interrogar-se sobre o valor da linguagem religiosa dentro da filosofia. Linguagem essa que o homem encontra e fala de seus problemas. Linguagem que deve ser analisada para ver se não existe nela uma resposta racional quanto à esperança.

\subsection{A análise filosófica da linguagem religiosa}

A palavra é um modo de finitude não é como a contemplação pura, a superação da condição humana, não é a palavra de Deus, a palavra criadora, mas a palavra do homem, um aspecto 
de sua existência militante; opera no mundo e nele produz algo; ou antes, o homem se exprime produz algo e se realiza, mas de modo diferente do que acontece quando trabalha (RICOEUR, 1968, p. 204).

Pode-se dizer que a palavra é uma realidade constitutiva do ser humano e que e autônoma acerca do gesto ou do fazer, pois o essencial da linguagem foge a natureza do trabalho: ela significa e não produz. A linguagem tem a capacidade de manifestar e dissimular a realidade; coloca a distância devida da imediata preocupação do viver, para refletir. O dizer pertence ao gratuito e não ao útil. Ao mesmo tempo leva a preocupação de viver, viver sob o plano do signo da esperança, pois esse precede e supera cada gesto, em razão de o significar. Por isso, o dizer opera sobre o plano da ação, enquanto diz ao outro, influencia o outro e ao sujeito que fala. Essa influência do sujeito sobre aquele que escuta se dá pela comunicação, ato pelo qual o sujeito dá a si mesmo e se transfere para o outro.

Para se fazer análise filosófica da linguagem religiosa, devemos colocar alguns pressupostos. Primeiramente, cada experiência religiosa é expressa em uma linguagem particular e para a interpretar é necessário analisar os modos pelas quais é expressa. Pode-se dizer que a linguagem religiosa é "sensata", existe nela um sentido próprio, ao menos para a comunidade na qual se exprime. E por último, a filosofia indaga o valor da verdade desse tipo de linguagem e deve encontrar os critérios de verdade adequados ao discurso religioso, pois a linguagem religiosa se distingue de todas as outras linguagens.

Através da análise linguística, a linguagem religiosa pode ser analisada. Ela examina todas as expressões recorrentes na palavra de "Deus", similar ou, ainda, da hermenêutica filosófica que se volta "a modalidade mais originária da linguagem de uma comunidade de fé, consequentemente, para as expressões com as quais os membros da comunidade interpretam, a título originário, a sua experiência para eles mesmos e para os outros" (RICOEUR, 2015, p. 03).

Ricoeur busca descrever e identificar, com o auxilio da hermenêutica filosófica, as formas do discurso pelo qual a fé da comunidade é expressa. Essa busca é um recuperar das expressões do tipo teológico-especulativas que surgem como 
conceitualizações da experiência de fé. Essas conceitualizações tornam-se depois uma racionalização gnóstica, pois perdem a sua raiz na forma de expressão da fé.

A fé da comunidade vem em forma de linguagem, organiza-se em um discurso no qual está uma taxis (disposição particular) que articular uma beuresis (descoberta) e uma lexis (expressão, a linguagem como língua). Deste modo, a fé se traduz em um discurso que está em um gênero literário, um estilo, uma mensagem.

As diversas formas de discurso manifestam significações e expressões diversas da fé, que dependem da forma de discurso operada. Esse manifestar é a abertura para um novo mundo, um mundo esquematizado.

O método de Ricoeur não parte do objeto, mas de um comportamento estruturado - a experiência de fé na comunidade - que é expressa na linguagem e, assim, delimita um âmbito da realidade sob a qual possibilita a necessidade de indagar as duas grandes famílias da linguagem religiosa.

\section{2- A manifestação e a proclamação como linguagem religiosa a partir de uma perspectiva filosófica.}

Ricoeur em sua pesquisa sobre a linguagem religiosa nota duas grandes famílias que correspondem a duas tomadas de atitude, a Manifestação e a Proclamação, e a dois tipos de pesquisas, fenomenologia do sagrado e hermenêutica da linguagem religiosa. $\mathrm{O}$ sistema totêmico e o sistema kerygmático são os dois polos do pensamento religioso, no qual a temporalidade tem ritmos diferentes com predomínio ora da diacronia e ora da sincronia.

A fenomenologia do sagrado, da manifestação, não se deixa reduzir a uma hermenêutica, pois conserva uma opacidade e uma densidade ligadas à força e não à forma. O sagrado, para a fenomenologia, é potência, é eficácia para além do sentido. Além disso, ele é ligado à hierofania que mostra que mesmo estruturada, não é verbal originariamente. Para a fenomenologia do sagrado, ele "se deixa descrever como modo de habitar o espaço e o tempo" (RICOEUR, 1974, p. 59).

Ademais, o sagrado se deixa ritualizar no rito, em um contemplar e em um fazer. No sagrado a natureza, o cosmo e seus elementos são manifestados com toda capacidade de significação estranha ao homem e mesmo que estra- 
nha se correspondem. Desta maneira, o simbolismo do sagrado é legado aos elementos que o constituem e que deixam transparecer o transcendente. Para confirmar isso, Ricoeur diz que “esse caráter 'ligado' do simbolismo, a sua aderência constitui toda diferença entre o simbolismo e a metáfora. Esta é uma livre invenção do discurso, aquele é ligado às configurações do cosmo" (RIOEUR, 1975b, p. 149).

O símbolo implica a presença constituinte de níveis de realidade que transcendem o domínio da linguagem. Vemos que tudo que foi dito até agora exige que o cosmo tenha uma capacidade de significar. Essa capacidade se baseia na lei da correspondência: algo pode simbolizar o divino, pois a história corresponde à história primordial, isto porque a história não se limita a dimensão discursiva. Assim, a hermenêutica da linguagem religiosa é um trabalho de interpretação sempre novo com o qual um grupo ou um indivíduo se apropria do conteúdo de sentido da palavra e dos escritos que fundam a sua existência comunitária e pessoal.

A hermenêutica, assim, sublinha o elemento "palavra" que pode ser escrita ou oral, o elemento "história" e a historicidade da tradição e da transmissão que é o momento proclamativo. Essa atuação proclamativa é típica da fé judeu-cristã, pois a palavra diz sob o "numinoso", porque ele é, apenas, o fundo no qual se destaca a palavra. Podemos dizer que a teologia judaica se organiza em torno de discursos diversos, porém ligados entre si: a narração, a profecia e a instrução ou lei moral.

A fé israelita recusa a imagem divina e põe no centro o nome divino como exigência moral. Os ritos não são repetitivos, mas ritualizados em eventos fundadores, com reapropriação do tempo. Podemos ainda dizer que, enquanto o sagrado porta uma teologia cósmica, a proclamação leva uma teologia histórico-ética. $\mathrm{O}$ mundo da fé israelita não está sob a lógica de sentido do universo sagrado, baseada somente na correspondência, mas por ela abre-se o anúncio e a narração.

No símbolo está algo que não pode ser exprimido pela palavra, que aparece como condição de possibilidade da linguagem metafórica poética e que Ricoeur chama de "legado" do símbolo, pois entre a manifestação e a proclama- 
ção, assim como entre o ressurgimento simbólico do sagrado e a "virtualidade" iconoclasta há um equilíbrio sutil e frágil manifesto na história da Igreja cristã, como a dialética do sacramento e da predicação (RICOEUR, 1974, p. 77).

Para Ricoeur o sacramento é a mutação do ritual simbólico no regime kerygmático. Essa mutação permite que a palavra se concretize e não somente à inteligência do homem, mas ao seu coração e a sua imaginação.

Entre a manifestação e a proclamação, Ricoeur mostra que a simbólica é baseada na lei da correspondência entre o cosmo, o homem e sua capacidade de exprimir o cosmo. Entretanto, sempre existe a dificuldade de exprimir a Revelação, por isso o homem recorre à poética, ou seja, à palavra proclamativa.

O símbolo, desta forma, para Ricoeur, sempre permanece nos limites de uma antropologia filosófica, pois "uma filosofia que parte da plenitude da linguagem é uma filosofia com pressupostos”(RICOEUR, 1999, p.374) e é um índice da situação do homem no coração do ser.

Esse momento do simbolismo humano é assinalado pela necessidade da superação da simbólica por uma poética, isso porque o homem se encontra diante de algo que supera a possibilidade deste e que somente pode ser proclamado e testemunhado à medida que não seja ligado ao dinamismo da correspondência simbólica, mas seja atualizador do fato histórico.

Desta forma, o simbolismo efetua uma superação e uma ampliação das nossas potencialidades cognoscitivas em direção a um "dá a pensar" dentro de um significar imediato.

Essa estrutura de duplo sentido encontra confirmação e aprofundamento na poética e na metáfora nas quais se fundam a possibilidade de acolher todas as possibilidades de cada antropologia filosófica e de cada simbolismo. Entretanto, o que permite a superação da simbólica pela linguagem é a atualização do mistério pascal que rompe a lei da correspondência, legado do universo sagrado, para abrir um universo "quebrado", que transcende a significação da expressão-limite "Reino de Deus".

O Reino de Deus como expressão-limite, com uma lógica absurda, intensificam o caráter poético da linguagem bíblica religiosa e impulsiona a pensar a existência de uma forma nova e diferente. 
A linguagem religiosa é uma linguagem metafórica que "redescreve" a realidade por meio e em função das expressões-limite que são as mais diversas narratividades bíblicas (discurso profético, narrativo, prescritivo, da sabedoria e hínico), que além de serem diálogos internos ao próprio texto, são expressões originárias da fé que nomeiam Deus junta e diversamente. Estas expressões, de acordo com Ricoeur, são expressões-limite acerca da condição humana retratadas no texto e que nos apontam em direção a uma esperança escatológica. As parábolas tem uma dimensão reveladora. Elas, vistas em suas interligações e intextualidade com outros gêneros bíblicos, ilustram uma linguagem que apontam para uma esperança futura, através da revelação.

O poder de revelação consiste na capacidade do modelo de incorporar de uma maneira coerente a série mais ampla possível de fenômenos, a fim de realizar um panorama de nossa experiência, juntando a essa ideia, a ideia de uma economia e de uma simplicidade de expressão em relação à gama complexa dos fenômenos (RICOEUR, 2006, p.206).

A inserção da poética para o estudo da linguagem religiosa ajudará a entrever o lugar da esperança cristológica na filosofia de Ricoeur.

\subsection{A poética e a linguagem religiosa}

Para Ricoeur, apropriar-se de um texto é apropriar-se de uma variedade de mundos que a linguagem sugere e induz por meio de seu potencial de sentido. A inserção da linguagem religiosa na perspectiva poética possibilita descrever a realidade de um modo novo, ver os pontos de interseções entre as hermenêuticas filosófica e bíblica. Possibilita até mesmo a mediação da linguagem e da escritura na construção de uma identidade religiosa que fundamenta a sua construção na interpretação de textos, como é o caso particular da linguagem religiosa.

Ricoeur é fiel ao seu método. Para ele, o que deve ser interpretado na obra é o mundo do texto e não a intenção escondida que o autor vai buscar no mundo do obra (coisa do texto) o que os textos bíblicos oferecem para a hermenêutica filosófica, pois "a interpretação de um texto completa-se na interpreta- 
ção de si dum sujeito que doravante se compreende melhor, se compreende de outro modo, ou que começa mesmo a compreender-se" (RICOEUR, 1994, p. 155). Dessa forma, há uma apropriação da parte do leitor que vence a distância cultural, tornando próprio um sentido que antes era estranho:

Aquilo de que eu, finalmente, me aproprio é de uma proposta do mundo; [...] A partir daí, compreender é compreender-se diante do texto. Não impor ao texto a sua própria capacidade finita de compreender, mas expor-se ao texto e receber dele um si mais vasto que seria a proposta da existência, respondendo da maneira mais apropriada à proposta do mundo (RICOEUR, 1996, p. 186).

Os textos se referem a um mundo, que é o mundo do texto. Esse o objeto da hermenêutica. $\mathrm{O}$ mundo do texto "não está nem atrás do texto como o autor presumido nem dentro do texto como a sua estrutura, mas desdobrada diante dele" (RICOEUR, 1996, p. 186).

O mundo, então, corresponde à proposta da existência, pois mundo é o conjunto das referências abertas por todos os tipos de textos descritivos ou poéticos que li, interpretei e amei. É, com efeito, às obras de ficção que devemos, em grande parte, a ampliação do nosso horizonte de existência.

Dessa forma tem-se que o texto assume uma configuração de obra com um estilo particular dependente do gênero literário. Essa obra abre o mundo do texto a uma referência própria e, consequentemente, a natureza dessa referência é poética, implicando, assim, a suspensão da referência ordinária e descritiva, em vista de uma referência dupla e redescritiva da realidade, que revela a pertença do homem ao real por meio da ficção.

O mundo do texto, assim, depende tanto do estilo como do gênero literário em que ele foi formado, de forma que não se pode ressaltar o conteúdo do texto desconhecendo a sua forma literária. $\mathrm{Na}$ linguagem religiosa não se está diante de um discurso descritivo ou cronológico, mas diante de um discurso poético, no qual a obra é uma poética generativa e a confissão de fé articulada pela forma de um discurso que se exprime, pois, "nomear Deus é, na melhor 
das hipóteses, uma atividade poética sem incidência sobre a descrição, isto é, sobre o conhecimento verdadeiro do mundo" (RICOEUR, 1996, p. 196-197).

A linguagem religiosa enquanto é dita através da metáfora é poética, pois fala sobre o desvelamento do nosso ser no mundo. A poética mostra aquela modalidade de nosso relacionamento com o mundo que não se exaure na descrição do objeto, pois para Ricoeur "essa função referencial do discurso poético contém [...] uma primeira aproximação do que pode significar a Revelação no sentido bíblico" (RICOEUR, 1996, p. 188).

A poesia revela, assim, uma verdade que não é aquela de adequação, sobreposta a verificação e a falsificação, mas uma verdade de manifestação da possibilidade do homem. Nomear Deus, então, para Ricoeur, não é tanto fazer teologia ou um ato que o homem seja capaz de fazer, é, na verdade, a revelação de um mundo que podemos habitar, mostrado pelo texto. A nominação, segundo o filósofo francês, de Deus não é simples, mas múltipla. Ou antes, ela não é monocórdia, mas polifônica. As expressões originárias da fé são formas complexas de discurso são tão diversas quanto narrações, profecias, legislações, provérbios, preces, hinos, formulas litúrgicas, escritos sapienciais. Essas formas de discurso nomeiam Deus todas juntas. Mas elas o nomeiam diversamente.

Se é dessa maneira, cabe-nos perguntar que coisa torna os textos poéticos bíblicos em religiosos?

A Palavra de Deus para Ricoeur é farta de problemas filosófico-teológicos e a nominação de Deus é um deles, porém aqueles problemas refutam o discurso ontoteológico que tendem a identificar o Ser e Deus, de tal forma, desemboca na ilusão de tornar Deus o objeto supremo, ou o sujeito supremo, pois "escutar a pregação cristã, para o filósofo, é primeiramente desfazer-se de todo saber ontoteológico, mesmo quando a palavra "Deus" nele figura. O amálgama entre Ser e Deus é sob o ponto de vista uma sedução sútil” (RICOEUR, 1996, p. 189).

A tendência de identificar o Ser e Deus é cessada pela ilusão de tomar Deus como objeto supremo, ou sujeito supremo. Essa dupla renúncia ao objeto e ao sujeito absoluto é o preço que se paga para entrar na linguagem radicalmente não especulativa e pré-filosófica. Podemos notar que na Bíblia o nome de Deus é polifônico e dependente do tipo de discurso em que é inserido. Esse 
fato é devido a que a apropriação entre a forma e a confissão de fé é diversificada pela nominação de Deus. Ao analisar o discurso profético, o narrativo, o sapiencial se nota que cada um desses sublinha uma característica de Deus que pode ser colocada em relação àquela outra forma de discurso.

A narração dos relatos bíblicos é relevante, pois é "aí que Deus é nominado". Deus, portanto, é designado como terceira pessoa, como agente último dos eventos particulares. No discurso narrativo se pode dizer que prevaleça uma teologia da história mais que em uma teologia da palavra, pois Deus se mostra na história.

O discurso profético, na linguagem religiosa, é impessoal, articulado pela palavra, pelo diálogo entre um Deus (Ele) e Tu. E a palavra que articula, que faz reler os fatos e que abre a uma inteligência mais profunda. Ricoeur nos diz que essa palavra não pode se articular em nenhum sistema, porque entre a segurança que é conferida pela narração dos eventos fundadores e a ameaça anunciada pelo profeta, não há nenhuma síntese racional, mas uma confissão dupla e plena que somente a esperança pode unir.

O discurso prescritivo assinala um aspecto tanto educativo como ético, pois o próprio Deus é autor da lei. Ele não nega as precedentes qualificações de modo que a lei é dada para que se mantenha a Aliança, conservando assim o evento fundador e libertador sob o anúncio do profeta. Desta forma, evita-se a heteronomia em prol de uma ética da perfeição que parte de Deus e para ele retorna, todavia, passando pela instituição, sem reduzir-se.

No discurso sapiencial é dirigido a cada homem para além do povo da Aliança. É uma situação limite em que o homem experimenta a sua grandeza e a sua miséria. A sabedoria busca os paralelismos colocados por Deus entre o cosmos e o ethos, entre a ordem do mundo e o agir, para encontrar uma harmonia e superar o sofrimento. Esse discurso unido aos outros encontra uma lógica presente no livro de Jó (que nos ensina que devemos esperar mesmo a despeito do sofrimento), do Justo sofredor. Essa lógica não encontra uma explicação na sabedoria para o sofrimento, mas somente em uma ação de fidelidade a Deus. O Deus da Sabedoria é um Deus pessoal que dá a sabedoria e que permanece imperscrutável. 
Os hinos, ou melhor, os discursos em forma de hino no qual os salmos se enquadram, mostram um Deus em segunda pessoa que é invocado na necessidade e glorificado na bonança. Nos hinos existe um sentimento que exprime algo em relação a Deus, já que o referente "Deus" exprime a circulação de sentido entre todas as formas de discursos em que Deus é nomeado. O referente "Deus" que é fundado na polifonia bíblica. Contudo, não é enclausurado nessa, mas a transcende. Ricoeur nos diz que: "a dialética da nominação de Deus é que Deus é designado ao mesmo tempo como Aquele que se comunica sob as mais diversas modalidades múltiplas [...] e Aquele que se reserva” (RICOEUR, 1996, p. 186), ou seja, onde ele se manifesta, mas, ao mesmo tempo, guarda para si seu maior segredo: a nomeação inominável.

No discurso religioso há também a presença de um processo qualificatório, que nada mais é que as expressões-limite. Para Ricoeur, "a narrativa-parábola repousa na conjunção de uma forma narrativa, de um processo metafórico e de um 'qualificador' apropriado que assegure sua convergência com outras formas do discurso, que apontam todas para a expressão 'Reino de Deus"'.

A linguagem religiosa é uma metáfora-limite. Ou melhor, toda e qualquer abordagem dialética dessa linguagem se abre ao poder de redescrição.

Por exemplo: cada parábola é uma mimésis da realidade em virtude do mythos e da poiésis que a opera. Assim, essa imitação da realidade é, no fundo, um redescrever legado ao gênero literário de que ela faz parte.

A parábola para Ricoeur encerra em si um processo metafórico, como na narração, que consiste não em uma quebra semântica em nível da frase, mas em nível da taxis, da composição de uma obra. Essa quebra indica um referente diverso daquele aparente que ultrapassa a estrutura narrativa. Cada parábola é um elemento de extravagância que não se permite ler como uma narração comum, mas ultrapassa o sentido da narração em direção a um referente ulterior. Ricoeur, assim, pensa que o aspecto que ultrapassa a estrutura narrativa seja a especificidade da parábola como um tipo de discurso religioso.

Há, entretanto, uma tensão semântica que está entre a forma narrativa e o processo que impele a ir além dos limites da narração, criando uma incoerência narrativa. Esse processo é o processo metafórico deflagrado pela presença 
das expressões-limite. Ricoeur quer entender como esse processo se dá e investiga todo o corpus das parábolas e faz notar que este forma um sistema próprio em torno da tensão entre uma situação de crise e a resposta a essa situação.

A análise do que é dito, feita no conjunto do Evangelho de Jesus, é a confirmação de que o extraordinário irrompe no ordinário e nos impulsiona a pensar o impensável. Ricoeur nos diz que: "as primeiras coisas que podem nos impressionar é que as parábolas são narrativas radicalmente profanas. Não há deuses, nem demônios, nem anjos, nem milagres, nem tempo antes do tempo, como na narrativa da criação [...] mas precisamente gente como nós [...] por um lado as histórias são narrativas da normalidade, mas por outro, é o Reino de Deus que se diz ser assim: o extraordinário e como o ordinário" (RICOEUR, 1996, p. 226). Assim, não é a pessoa religiosa em nós que é interpelada nessas histórias, mas a pessoa profana.

Ricoeur diz que "a tensão entre a forma parábola e a forma evangelho é inevitavelmente uma parte da significação da parábola, como narrativa e como metáfora”(RICOEUR, 1996, p. 192). Nisso vemos que há uma especificidade da linguagem religiosa que merece ser estudada diante da filosofia, ou melhor, por uma hermenêutica filosófica como aquela que diz de maneira única as narrações e fatos.

\subsection{A linguagem religiosa e sua especificidade como linguagem que expres- sa fatos da existência humana}

As expressões-limite não qualificam a linguagem como religiosa, mas a intensificam.

Essas expressões-limite têm seguramente a imensa virtude de chamar a atenção para a especificidade da linguagem religiosa, mas não a constituem por inteiro. Elas só trabalham no meio de uma linguagem essencialmente analógica ou metafórica, ela mesma gerada pela nominação narrativa, prescritiva, profética e finalmente parabólica de Deus (RICOEUR, 2011, p. 201).

A forma literária constitui o esquema ou modelo que fornece imagens que constitui como religiosa, uma linguagem extravagante, a nominação de 
Deus. O nome de Deus é o referente último da linguagem religiosa. Ele permanece e funda a polifonia bíblica. Contudo, o referente Deus é cultivado na convergência das várias formas de discurso.

A palavra Deus é mais ampla que a palavra Ser e abre um horizonte que nenhum discurso pode delimitar, pois ela flui dos múltiplos discursos que se mostram incompletos.

Nas expressões-limite, as mútuas relações e a sua incompletude fornecem o elemento de transgressão com o que se pode transcender em direção ao Todo-Outro. Ricoeur vai na direção contrária às teorias de Karl Barth e a de Rudolf Bultmann. Para esses, as parábolas dizem somente sobre uma tomada de decisão em tempo de "crise". Essa crise para Ricoeur é o Reino de Deus, o qual desorienta e confunde a forma do discurso que foi modificado, tornando-se indicativo do ponto de encontro com o infinito que está no centro do problema.

A proclamação, para Ricoeur, na expressão proverbial e na extravagância das parábolas, que traz o Evangelho, exerce a estratégia reorientação e de uma desorientação. Como na metáfora a referência metafórica brota do abandono da via do ordinário.

Os ditos proclamatórios-apocalíticos impulsionam renunciar ao enquadramento cronológico típico daquele gênero literário; enquanto que nos provérbios o paradoxo leva a superar a sabedoria humana. Na parábola a extravagância rompe a calma e o ordinário da narração. Ricoeur justifica recapitulando o que disse Ramsey (1957) a propósito da relação modelo-qualificador.

Vejamos, para Ian Ramsey a linguagem religiosa sempre faz referência ao mundo sensível através da linguagem ordinária. Entretanto, ela exprime algo mais que revela uma dimensão transcendente, possibilitando a compreensão daquilo que foi dito. A relação modelo qualificado, existem termos, descrições, modelos que são extraídos da linguagem comum. Esses modelos são ampliados por qualificadores especiais, inadequados, mas capazes de expressar e dirigir os modelos em uma determinada direção religiosa. Esses modelos são utilizados então como conceitos-limites do tipo: infinito, causa primeira, incriado. Esses conceitos-limites são próprios da linguagem religiosa para manifestar a situação transcendente. Pois, “o atributo intervém para levar a seu 
limite o que o contraste sugere no contexto da linguagem ordinária. É então aquilo pelo qual a palavra Deus preside o resto da linguagem e aquilo em que a completa" (RICOEUR, 2011, p. 201). Os modelos qualificadores permitem que vejamos a lógica contida nas parábolas e provérbios que, sem eles, passam em silêncio e sem expressão. Ou seja, a partir desses modelos podemos compreender a lógica embutida na linguagem religiosa.

A extravagância da parábola e a hipérbole dos provérbios e das proclamações escatológicas funcionam como modelo e qualificador dentro da linguagem religiosa. $\mathrm{O}$ poder da revelação, segundo Ricoeur, consiste na capacidade do modelo de incorporar de uma maneira coerente a série mais ampla possível de fenômenos, a fim de realizar um panorama de nossa experiência, juntando a essa ideia, a ideia de uma economia e de uma simplicidade de expressão em relação à gama complexa dos fenômenos.

Ricoeur nos mostra que, para Ramsey, o primeiro grupo de palavras significativas da linguagem religiosa é o da teologia negativa, ou seja, quando Deus é nomeado imutável ou impassível. Assim tudo é mutável diante dessa linguagem, porém nem tudo muda.

Em um segundo grupo, temos palavras na linguagem religiosa como: uno, simples, perfeição que evocam o contrário da pluralidade, complexidade, ambiguidade, pois "o atributo intervém para levar a seu limite o que o contraste sugere no contexto da linguagem ordinária. É então aquilo pelo qual a palavra 'Deus' preside o resto da linguagem e aquilo e que 'a completa'”(RICOEUR, 1996, p. 201).

Já o terceiro e último grupo da linguagem religiosa, diz respeito às expressões: causa primeira, criação ex nibilo, plano eterno. Temos então que a palavra "causa" constitui um modelo para explicação e a palavra "primeira" modifica o modelo, que faz corresponder a algo correspondente. A palavra Deus completa as histórias causais, pois é anterior àquelas histórias, ou seja, é a primeira palavra. Quando, então o qualificador ex nibilo é colocado ele nos força a trabalhar toda a nossa experiência de criação, quer dizer, sinaliza uma experiência única de extravagância.

Assim, os gêneros literários são modelos. A nominação de Deus é o qualificador que faz ver uma modalidade que a lógica tende a ignorar. $\mathrm{O}$ escân- 
dalo lógico, assim, que é fornecido pelas expressões-limite, acentua os limites do poder metafórico de redescrever a realidade ligada à ficção narrativa.

Diante de tudo isso que foi dito, cabe uma pergunta: qual poderia ser o referente último, ou melhor, o âmbito da realidade da ficção poética do qualificador “Deus” ou “Reino de Deus”? Para Ricoeur, as expressões-limite orientam as experiências-limites da vida humana, pois

Falar de experiências-limite é falar de nossa experiência. Essa expressão não diz de modo algum que nada há em nossa experiência humana comum e em nossa linguagem comum que corresponda à palavra sobre o extremo $[. .$.$] é$ precisamente como extrema que a linguagem religiosa é apropriada. É essa adequação de expressões-limite que é significada por nossa afirmação de que a linguagem religiosa, como toda linguagem poética, no sentido mais forte do termo, redescreve a experiência humana (RICOEUR, 1996, p. 207).

A linguagem contida na confissão de fé não pretende descrever o mundo, mas dizer sobre a nossa atitude no seu confronto, segundo uma dupla diretiva: a do discernimento singular e a segunda do compromisso total. Ou seja, assim como a linguagem religiosa tende a mostrar que a experiência particular correspondente à forma literária, da mesma forma tente a alargar essa experiência particular para um significado universal.

As expressões-limites propõem produzir uma redescrição por meio de uma desorientação, por meio de um escândalo, de um paradoxo. Isso revela ao homem a experiência-limite que mostra toda precariedade das soluções que lhes são propostas. Desta maneira, “o momento propriamente religioso de todo discurso, inclusive do discurso político, é o 'sempre mais' que ele insinua em toda parte, intensificando todo projeto da mesma maneira, inclusive o projeto político” (RICOEUR, 1996, p. 207).

Assim colocado, o discurso religioso porta um paradoxo, não por afirmar uma verdade última, mas por desorientar os discursos particulares que tendem a se fazer um sistema absoluto e reorientar para algo que é sempre outro e imprevisível. 
Ricoeur nos faz ver que a linguagem religiosa com seus extremismos é adequada para falar da experiência humana e que essa inclusive é marcada de extremismos. É na linguagem religiosa que se revela a dimensão do incondicionado presente na experiência humana: "o que a linguagem religiosa faz é redescrever, o que ela redescreve é a experiência bumana. Nesse sentido, devemos dizer que o referente último das parábolas, provérbios e dizeres escatológicos não é o "Reino de Deus", mas a realidade humana em sua totalidade, assim como essa é interpretada à luz dos recursos miméticos da linguagem religiosa, baseada em sua invenção realista e estranha que é inserida na narrativa específica. Tudo isso só poderá ser aceito, aceita-se que a linguagem religiosa seja sensata e que, por conseguinte, mostre o que quer.

Ricoeur admite que o homem tem a possibilidade, a partir da experiência comum, de dizer algo sobre o que é extremo, como acontece nas situações-limite. As situações, como a morte, a culpa, o sofrimento, tem um ponto de convergência: o limite de nossa existência empírica. Esse limite não é o que impede alguém de escolher, por assim dizer, determinadas coisas, mas se trata de um limite a toda existência empírica, ou seja, é um ponto que a existência empírica não consegue atravessar. Ou melhor, a linguagem religiosa lança a sua radical visão sobre a experiência comum mostrando explicitamente a potencialidade da dimensão religiosa.

Para Ricoeur, a linguagem religiosa não imagina a experiência-limite, mas a revela, quer dizer, expõe nela algo do texto que o homem compreende. Ele a reconhece como sua experiência mais profunda. Essa é a conclusão a que se chega a hermenêutica filosófica que indaga sobre a fé.

Para a filosofia, a fé não é uma experiência imediata, mas é sempre uma experiência articulada em uma linguagem. Essa experiência se lança a interpretar o mundo do texto que ela está interpretando. Isso significa que a hermenêutica descobre a fé somente quando essa, por meio do texto, é comunicável e transmissível e não enquanto experiência pessoal de decisão que confia em uma vontade que sempre a precede. Esse sentimento de dependência absoluta não é hermenêutico, nem é investigado pela hermenêutica, mas constitui o início e o término, mesmo que esse início e esse término sejam ligados a uma 
linguagem que é exatamente objeto da hermenêutica, a qual é capaz de despertar uma nova possibilidade para a liberdade.

Outro tipo de linguagem religiosa é a linguagem teológica que coloca a modalidade simbólica como expressão conceitual. Ela se serve da meditação da linguagem filosófica e, dessa forma, procura ligar as expressões religiosas com o mundo cultural do leitor. Essa passagem encontra motivação histórica na cultura judaica que se defronta no dever de dialogar com a cultura grega, de postura metafisico-filosófica, especialmente sobre o problema de Deus.

O conceito de Deus, "pertence a uma onto-teologia na qual continua a organizar a constelação inteira das palavras-chave da semântica teológica, mas no interior de um quadro de significações prescritas pela metafísica" (RICOEUR, 2006, p. 209). O problema é introduzir uma relação entre a experiência articulada do texto bíblico e a experiência humana dentro do gênero literário, vista como uma totalidade, considerando sempre que é a experiência religiosa que redescreve toda experiência humana.

Para fazer isso, Ricoeur se utiliza do método da correlação, ou seja, "se trata de articular o espaço de confronto, entre as duas grandes fontes do discurso teológico" (RICOEUR, 2006, p. 212), ou melhor, o significado dos textos religiosos e os significados da experiência humana.

Essa tarefa é difícil, principalmente hoje, pelo fato de que as fontes religiosas são contestadas e reduzidas por uma hermenêutica redutora, uma vez que é "necessário conceder que essas interpretações redutoras estão na linha do objetivo semântico característico da ordem especulativa. Toda interpretação visa reinscrever o esboço semântico delineado pela enunciação metafórica em um horizonte de compreensão disponível e controlável conceitualmente.

É necessário pensar através do conflito das interpretações e fazer um trabalho crítico-reflexivo e recuperar experiência religiosa. Incute-se, então, a necessidade de estudar a linguagem religiosa da confissão para descobrir a potencialidade conceitual, pois "a dinâmica da significação, que orienta o figurativo para o conceitual, deve ficar sob o controle do potencial hermenêutico da metáfora” (RICOEUR, 2006, p. 213). Ou ainda, a capacidade da confissão de 
ser expressa conceitualmente, garantindo assim a correlação com a experiência humana que é expressa conceitualmente.

Para Ricoeur, cada conceitualização é culturalmente determinada e, assim, é possível encontrar uma conceitualização do religioso que venha de fato estabilizar a correlação com a experiência humana e com um diálogo da cultura daquele tempo.

O conceito brota da forma em que se organiza um mundo no qual suas estruturas são apontadas conceitualmente. A forma tem como ponto de partida a imaginação esquemática que, enquanto esquemática, se baseia na cultura e na tradição que pode se projetar na forma. Por isso é de fundamental importância para Ricoeur estar situado em uma tradição.

A linguagem religiosa não é, em si mesma, um único nível, mas se reproduz sob uma dupla tensão entre a imaginação e o significado que exige uma interpretação, "de um lado ela quer a claridade do conceito, de outro, procura preservar o dinamismo da significação que o conceito detém e fixa” (RICOEUR, 1999, p. 464), é o velho problema da relação entre kerygma e hermeneia.

Cada linguagem simbólica exige uma interpretação, pois cada símbolo, enquanto construção de sentido, requisita um ato da linguagem a partir de uma interpretação literal de uma expressão, apesar de não vir esgotada de recursos de significação. Ricoeur, todavia mostra que os símbolos têm significados inesgotáveis e que é na linguagem religiosa que isso é evidente, porque "nenhuma interpretação pode esgotar sua significação, nem mesmo a interpretação histórica” (RICOEUR, 2006, p. 213).

Ao abrir para a possibilidade de infinitas interpretações, Ricoeur, sugere uma relação necessária entre interpretação e situação do intérprete, que varia sempre. O critério de controle da reinterpretação é o confronto na relação de analogia entre interpretação e a situação de nossos dias; e a interpretação e a situação passada. Em virtude da interpretação, o símbolo vai ao encontro do conceito, mas graças à dependência da intepretação da situação e da expressão metafórico-simbólica existe a possibilidade de elaborar uma noção de conceito que não reduza a inesgotável potencialidade simbólica. 
Trata-se de uma linguagem semi-conceitual em que existe uma função de traduzir a linguagem simbólica em um ambiente no qual é retomado conceitualmente. Assim, entre o símbolo do "Reino de Deus" e a expressão paulina "Justiça de Deus" se estabelece um fenômeno de tradução de uma linguagem simbólica a uma linguagem semi-conceitual. A linguagem religiosa não usa as expressões limites. Contudo, para abrir a experiência. Essa permite que a reflexão teológico-conceitual se exercite. A garantia de continuidade entre as duas expressões e, desse modo, de validade da tradução, é a identidade "lógica" que as duas expressões querem afirmar. De fato, seja dizendo "Reino de Deus" ou "Justiça de Deus" entende-se que se está afirmando uma "lógica da superabundância" que comporta um algo a mais, os elementos de surpresa e de extravagância na parábola, pois em ambos lugares uma lógica ordinária colapsa e a lógica de Deus, que não é uma lógica de identidade, mas uma lógica de algo mais, surge.

Assim, pode-se se perguntar: há um certo uso do pensamento que preserve a tensão entre figura e significação, enquanto prolonga o papel dos qualificadores no nível conceitual?.

Para responder, Ricoeur faz duas afirmações para ter uma correspondência entre expressões-limite e conceitos-limite.

A primeira afirmação, dá-se acerca do princípio hegeliano segundo o qual o mundo da religião é o processo perpétuo que costuma engendrar forma e abolir formas. A forma determina a morte dos ídolos para passar da representação ao conceito. Hegel afirma que o absoluto está no saber, isso Ricoeur refuta repetindo o famoso juízo de Barth sobre Hegel: a maior 'tentativa' (Versuch) e a maior tentação (Versuchung).

A segunda afirmação de Ricoeur é o recurso a Kant: nele não se dá uma teologia especulativa como ciência do "objeto". Contudo, é sempre possível uma consciência objetiva, porém não absoluta. Kant distingue, assim, entre o intelecto (vertand) e a razão (vernunlt). O primeiro é a faculdade da consciência condicionada, pois é a faculdade de pensar o objeto pela intuição sensível. A segunda se refere à faculdade dos princípios, ou seja, a função do Incondicionado. Entre essas duas existe uma distância que Kant chama "limite". Dessa forma, há um ato que a razão põe para o intelecto ou a consciência para o objeto, não esgotando a 
capacidade da razão. Por isso para Kant a metafisica é a pretensão do intelecto em absolutizar-se na Ilusão transcendental. Consequentemente, a busca pelo Incondicionado é sempre "vazia”, pois não é mais plena do objeto.

Ricoeur expõe que essa conclusão depende do fato que Kant conhece somente a linguagem empírica, então Ricoeur pensa que através da linguagem metafórica seja possível a apresentação do Incondicionado.

A poética e a simbólica elaboraram uma linguagem indireta, nominal e hermenêutica que mostra não o que é o Incondicionado, mas que coisa ele é. Assim, diz-se que isso não é isso que é dito na representação simbólica.

Deste modo, Ricoeur retém o "limite" kantiano, pois a linguagem metafórica não é objetiva. Isso nasce da tensão entre a interpretação literal e a interpretação metafórica. A linguagem metafórica dá uma apresentação figurada do incondicionado e permite uma retomada especulativa graças aos conceitos-limite que formam e mantêm a tensão semântica pela qual a metáfora permanece sempre uma semelhança e não mais igualdade. Um bom exemplo de linguagem metafórica é a parábola da semente de mostarda.

Existe, assim, uma consequência prática diante da linguagem metafórica, a hermenêutica tem por tarefa permitir a apropriação do nosso esforço de existir e, por isso, os conceitos do saber especulativo não podem ser os mesmos que os conceitos-limite mostram "diante de nossa imaginação as figuras da existência autêntica" (RICOEUR, 2006, p. 220).

Não se trata dos conceitos no sentido próprio e completo do termo, mas das formulações "éticas", ou seja, as formulações a respeito das mediações com os quais o homem realiza o seu desejo de existir. Essas mediações são poéticas e o saber conceitual nada mais é que "uma pesquisa transcendental sobre a imaginação da esperança” (RICOEUR, 2006, p. 221), pois é tarefa da ética articular seu discurso coerente, entendendo o que dizem os poetas.

Isso somente vem confirmar o pensamento de Ricoeur, pelo qual o homem tem sempre necessidade de uma figura possível sobre a qual decide. É interessante ver que a figura vista é paradoxal e impulsionada em direção à outra figura. Assim, a decisão prática também será um transcender. 
Como vemos, pode-se falar de Deus na filosofia a partir dos limites da razão, graças aos símbolos que estão na linha fronteiriça entre o que podemos dizer "no interior" e "além" da razão: "seu estatuto é antes o de um 'esquematismo’ da esperança" (RICOEUR, 2006, p. 221). Assim,

a necessidade do simbolismo religioso para designar a mediação entre o reconhecimento do mal radical e a confiança no triunfo do bom princípio. A figura crística representa um esquematismo consciente, graças à capacidade reflexivoespeculativa do homem. Dessa maneira, o homem não pode conhecer o Indeterminado, mas somente esperá-lo mais que um simples herói do dever, menos que uma kênosis do absoluto, mas nos estritos limites da teoria da analogia, um autêntico esquematismo da esperança (RICOEUR, 2006, p. 38).

Esse esquematismo da esperança, mostrado na lógica de uma superabundância gratuita, passa pela figura de um Deus cooperador, que tenta perdoar a todos e que envia seu filho, Cristo, para salvar o mundo. É nesse ponto que o indivíduo se torna solidário por causa de uma humanidade ferida pelo pecado, mas reconfigurada em Cristo. Ele se torna solidário do ser humano, a ponto de dar a sua vida pelo outro, para que o outro se beneficie da salvação ofertada por Deus. Essa lógica da expiação é usada para resolver o problema do sofrimento do justo.

O homem, em resumo, pode apresentar a hipótese de uma Transcendência, pois "a ideia de Deus como ideia kantiana é o grau-limite de uma liberdade que não é criadora" (RICOEUR, 1950, p. 455). Entretanto, não posso ter uma figuração somente simbólica e sempre aproximativa, a qual é revelada e não imaginada. Por isso, a hipótese da transcendência é somente esperada, escutada e não fundada por ela. A nossa linguagem sobre Deus se reproduz ao redor do referente "Deus", às expressões-limite e aos conceitos-limite mostram um sentido que sempre precede o homem. Assim, o sentido não é criado pelo homem, mas lhe é dado.

Cabe-nos agora analisar a hermenêutica filosófica e a hermenêutica teológica a fim de definir a que ponto chega a linguagem religiosa a respeito da esperança. 


\section{Entre a hermenêutica filosófica e a teológica: o fundamento da esperança}

A centralidade do símbolo no pensamento ricoeuriano é inegável, dado ao fato que o símbolo expressa o Incondicionado. É sobre a hermenêutica do símbolo que se encontram ou simplesmente têm início em direções diferentes a hermenêutica filosófica e a teológica. O ponto de partida de cada uma dessas hermenêuticas do símbolo ou da linguagem religiosa é a posição que tal linguagem é portadora de um sentido. Ou seja, diz algo sobre o enraizamento do homem no mundo.

A linguagem religiosa é comunicada e dada segundo as regras da linguagem, por isso é tarefa da hermenêutica indagá-la. A hermenêutica teológica é inserida por Ricoeur em uma elaborada teoria global que busca harmonizar o conflito das intepretações e salvaguardar a especificidade de cada abordagem hermenêutica. Nisso,

a linguagem religiosa é uma variedade de linguagem poética [...] até certo ponto, com a condição que não identifiquemos "poética" com "estética" e respeitemos o alcance da função poética [...] como poder de fazer corresponder a redescrição da realidade [...] a linguagem religiosa das parábolas é um exemplo da linguagem poética. Contudo, é precisamente na base da poética que a linguagem religiosa revela seu caráter específico, na medida em que a função poética pode aparecer, no sentido inverso, como medium ou o organum da linguagem religiosa (RICOEUR, 2006, p. 192).

O esquema para um conhecimento simbólico em Ricoeur vale como base para a nossa reflexão. Esse esquema é desenvolvido em cinco etapas:

1. A experiência do símbolo é o ponto de partida no qual o homem experimenta o significado daquilo que pode ser compreendido. Ele não somente experimenta conhecer, mas se depara com o surplus de sentido que nenhuma reflexão é capaz de esgotar, por isso a reflexão faz referência ao símbolo;

2. Expressão e experiência - O homem exprime linguisticamente cada experiência a fim de comunicar-se e cada símbolo sempre na palavra dá a pos- 
sibilidade de uma recuperação filosófica do símbolo. $\mathrm{Na}$ verdade, não se dá o símbolo sem intepretação e sem linguagem;

3. Reflexão sobre a experiência e expressão. Nessa etapa é o trabalho do filósofo expor todas as intepretações possíveis para conciliar os conflitos interpretativos e, assim, elaborar as condições de possibilidade da norma de verdade e para acercar-se da apropriação existencial do símbolo;

4. A aposta - Os símbolos não são totalmente sistematizados, situado no seu caráter "legado" do concreto. Cada juízo é somente uma opinião provável sobre o qual cumpre-se apostar, tomar uma posição de decisão essencial.

5. Experiência do símbolo como segunda ingenuidade. Um retorno a capacidade de crer depois de ter passado pela crítica. Ele não propõe uma volta ao irracional, mas uma reflexão, uma hermenêutica do símbolo, pela qual há uma escuta, uma escuta instruída. Para recuperar o símbolo, o homem moderno deve re-experimentá-lo, revivê-lo, mas não na ingenuidade do homem pré-copernicano, mas em uma espontaneidade crítica, refletida.

Dada a dimensão ética da hermenêutica de Ricoeur e pelo fato que não se pode fazer filosofia sem pressuposição, iniciando do nada, se não nos dispusermos a isso, muito provavelmente, será difícil distinguir a hermenêutica filosófica da teológica. Temos que ter em mente que o discurso filosófico não parte de um ponto zero, sem um pressuposto. Ele parte daquele esforço de compreensão do ser humano a partir da sua realidade.

Ricoeur tem claro que a Hermenêutica Teológica não é somente uma aplicação da Hermenêutica Filosófica, mas que entre as duas existe uma relação de correspondência profunda, sem que a primeira se torne a segunda, nem a segunda a primeira, porque "indubitavelmente, o movimento de início parte do polo filosófico e se dirige em direção ao bíblico” (RICOEUR, 2014, p. 79), pois as categorias interpretativas são as mesmas.

Quando aplicada aos textos bíblicos, a hermenêutica filosófica subordinada, por assim dizer, à teológica, serve de instrumento. Isso é devido ao fato que o ponto de partida da hermenêutica é a experiência do símbolo. Se a experiência do símbolo é teológica, então a perspectiva e regra domina todo o 
procedimento. Ocorre que, ao fazer uma experiência teológica do símbolo, a hermenêutica filosófica chega a um ponto que não pode mais continuar.

Diante dessa questão filosófica, se avizinha o problema da Revelação, como palavra de Deus que volta ao homem e revela toda importância da reflexão ricoeuriana sobre a poética. Esse discurso se estrutura em torno da hermenêutica da ideia de revelação e daquela hermenêutica do testemunho, que mostram as relações entre a hermenêutica filosófica e teológica.

O passo seguinte é que o problema da relação entre fé religiosa e fé filosófica, é um problema limitiforme válido e próprio da hermenêutica teológica que se organiza sob o tema da demitologização. Ela quer despir o kerygma de sua roupagem mítica e se diferenciar da demitização, salvo os apontamentos da poética.

Ricoeur, entretanto, nos seus escritos, conserva a certa especificidade cristã, conforme será posteriormente mostrado, sem se distanciar da filosofia, ou mesmo fazer teologia, pois na sua concepção simbólico-poético-hermenêutica do Sagrado há uma Esperança enlaçada na Cristologia.

Podemos salientar que: $\mathrm{Na}$ obra de Ricoeur é possível ver três momentos nos quais a insurgência do problema hermenêutico coincide com o cristianismo e com a primeira geração cristã, revelando os nexos entre a hermenêutica filosófica e a bíblica. São eles: 1) Em relação ao Antigo testamento;2) A instituição da relação entre hermenêutica e existência a partir das Escrituras e 3) As Escrituras são textos como todos os outros. Ricoeur nos mostra que o cristianismo é sempre conotado como um momento insuperável, pois é um momento interpretativo da vida a partir de textos escritos.

\subsection{A Palavra: como ponto central do Cristianismo e dos procedimentos filosóficos diante de uma hermenêutica filosófica}

Para Ricoeur a Palavra é o ponto central do cristianismo. Não é de se estanhar tal fato diante dos mais diversos escritos sobre assuntos relacionados ao mundo cristão e por que o próprio coloca a palavra como algo central na sua filosofia hermenêutica-reflexiva. 
Dentro da linguagem religiosa e, sobretudo, de seus caracteres reveladores da experiência humana, se pode perceber a importância da palavra na experiência cristã e na teologia cristã.

Ricoeur afirma muitas vezes que a palavra é o ponto central do cristianismo. Ricoeur descobre dois momentos que mediam a teologia da história e a teologia da palavra redirecionando o campo teológico para o par evento-sentido. Essa exposição é que permitirá clarear o sentido que tem para Ricoeur a teologia e apresentar as contribuições das ciências da linguagem à metáfora e à teologia.

Será bom esclarecermos como Ricoeur supera a "teologia da história" por uma "teologia da palavra", se assim se pode dizer.

\subsection{O evento histórico e o evento da palavra em relação ao discurso}

Para Ricoeur a teologia da história se propõe levar à linguagem uma experiência hermenêutica constituída a uma esfera diversa da linguagem, e co-originária. A base dessa hermenêutica teológica da história é a convicção de que as hermenêuticas estética e histórica precederam a hermenêutica linguística. Isso se afirma, pois a hermenêutica é concebida como informação sobre a "coisa" mesma.

Ricoeur elabora a noção de evento histórico, noção central e descriminante entre a teologia da palavra e a teologia da história. $\mathrm{O}$ evento advindo na história está junto a algo distante e separado de nós. É algo que vem e chega a nós, através do discurso. Faz-se necessário estudar a relação entre discurso e evento, pois para Ricoeur, não descobrimos a alteridade do evento graças a uma estrutura de discurso que permite tal reconhecimento, ou seja, a referência a qual é o "outro do discurso", que está no discurso. A hermenêutica do discurso pode permitir a apropriação do evento que está distante.

O problema é o de notar a ligação entre evento histórico e o evento da palavra, ligação que para Ricoeur se resolve na afirmação que o evento histórico se torna histórico somente quando narrado.

Pode-se dizer que a teologia da história de sua parte, se tida como certa, diz que o fato em si é inalcançável. Retém que o sentido do evento não surge pelo evento, mas da conexão histórica que se estabelece entre evento e intér- 
prete. $\mathrm{O}$ evento percorrendo a conexão histórica pode buscar sentido nessa e "sentir-se" na história, na sua concatenação.

Ricoeur, porém, se pergunta se se pode falar de conexão histórica sem interrogar-se sobre a constituição histórica do compreender e sem referir-se à linguagem, pois a historicidade diz respeito à decisão ética pessoal.

A historicidade e a narrativa se exigem entre si, pois o sentido da histórica é constituído pelas narrações que a comunidade constitui e reflete sobre elas. Para Ricoeur, a historicidade é a inserção da existência presente no curso da história - a co-pertença à própria história que narra e da qual os eventos re-contam. A constituição conjunta e recíproca da história do passado, da história da tradição e do sentido da existência presente, a partir da qual o indivíduo, um grupo, um povo, uma nação reaprenda sua história. Em suma, a historicidade designa a relação circular entre a razão histórica e o sentido concedido ao presente do sujeito da narração.

Existe uma circularidade hermenêutica entre história re-contada e presente daquele que re-conta. A afirmação típica da teologia da história, de buscar o sentido na história universal, é correta para Ricoeur no sentido que a história universal é o horizonte no qual confluem dois horizontes distintos: o da nossa experiência presente e a experiência do texto. Desta maneira, o horizonte histórico universal não é mais total. Se o fosse saberíamos o começo e o fim da história. Contudo, requer-se dizer que se pode falar de horizonte somente em um processo hermenêutico da palavra, no qual texto e decisão se unem.

A última afirmação da teologia da história é que a totalidade da história é determinada pela abertura a seu futuro, abertura que procede da ressureição do Cristo. Na prática, substitui-se o saber absoluto de Hegel pela escatologia cristã, segundo a qual o nosso conhecimento sobre o fim da história é sempre provisório, antecipado no evento Cristo e, assim, é sempre em uma totalidade dada.

Ricoeur mostra que as afirmações, pela correspondência entre expressões-limite e conceitos-limite, estão ligadas à intepretação do texto bíblico e que sem ele elas não se sustêm. De fato, a história escatológica, significa adiar o sentido do presente ao futuro, do qual não se dispõe e que a história, sozinha, não pode indicar. Ocorre aí uma mensagem escatológica que gere a esperança 
como intepretação de uma promessa. Assim Ricoeur diz que a esperança mostra mais que uma simples possibilidade de fazer coincidir o horizonte temporal em um só horizonte. Ela envolve uma ligação supralógica, que vai além das antinomias tradicionais que se harmonizam na esperança. Ela projeta o futuro como cumprimento da promessa contida na ressureição de Cristo, pois "a esperança é esperança de ressureição, de ressureição de entre os mortos" (RICOEUR, 1999, p. 412).

Que a ressureição de Cristo seja um evento do fim, não entra na possibilidade de que eu disponho, mas é uma possibilidade que me é dada mostrar, graças a uma hermenêutica que revela a dialética do evento e do sentido no discurso da promessa.

Se a decisão do homem toma sentido não da existência, mas de um eschaton, então ocorre utilizar um trabalho hermenêutico que revele e dê a esse sentido, dentro do evento escatológico, o que é gratuitamente anunciado.

Ricoeur sintetiza em torno do conceito de Kairos os quatro momentos do discurso: a) Kairos é um encontro entre um evento histórico e um evento da palavra; b) Kairos é a conjugação entre sentido e evento, um evento pleno de sentido e um sentido que aparece do evento. Essa unidade é possível no discurso, que une o evento e o trans-evento; c) Kairos é aquela fusão dos horizontes abertos do texto e da decisão existencial e d) Kairos é o presente escatológico, ou seja, o fundamento da esperança e o cumprimento da promessa advinda em Cristo ressuscitado.

Isso acontece quando o homem acolhe em sua vida a superabundância do sentindo sobre o não sentido, ou melhor, a dimensão aberta da ressureição e da narração interpretativa dessa.

\subsubsection{As contribuições dos estudos filosóficos e linguísticos para a Teologia da palavra}

Fixada a correlação entre história e palavra, Ricoeur analisa filosófica e linguisticamente a teologia da palavra e estabelece a importância dos contributos que os estudos filosóficos e linguísticos dão a ela. 
A teologia da palavra se baseia em cinco fundamentos: 1) Deus encontra o homem como palavra, 2) O cristianismo é a compreensão dessa Palavra enquanto Verbo encarnado, 3) O testemunho da comunidade cristã primitiva é a palavra de predicação, lugar em que o evento Cristo é reconhecido como palavra, 4) A pregação atual é uma ritualização e compreensão da pregação primitiva e 5) O trabalho exegético-teológico é um discurso que tenta recuperar o significado da Palavra original que coloca em movimento todo o seguimento de outras palavras. "Igualmente o trabalho do teólogo parece esse mesmo como um último discurso endereçado à conexão interna e íntima entre a Palavra de Deus, Deus como Palavra de Cristo, a palavra da pregação primitiva e a sua atualização na predicação moderna" (RICOEUR, 2015, p. 02).

Todo esse trabalho hermenêutico deve ser unitário, pois unitário é o processo de seu objeto. A teologia deve indagar sobre sua origem, sua modalidade de transmissão, sua relevância atual e a pensabilidade do objeto. Ou seja, o problema hermenêutico é central, pois a hermenêutica não é "um discurso de segunda ordem aplicado à regra de leitura do texto; essa concerne à constituição do objeto como 'Processo de palavra"' (RICOEUR, 2015, p. 02).

A hermenêutica é a teoria do compreender em relação à explicação do texto em geral, assim essa é a teoria geral do sentido a partir da teoria geral do texto. Por isso, a exegese é insuficiente como teologia, pois essa não é capaz de dar conta de um fato essencial para a Bíblia, ou seja, que a Bíblia é um documento cujo destinatário, Israel, é o seu próprio autor. A teologia é constituída como tal de um objeto irredutível a qualquer outro objeto disponível para o homem, a saber, a Palavra de Deus. Essa é um evento gratuito e fundador, que se dá ao homem de modo humano, ou seja, no processo da palavra.

Por esse motivo Ricoeur estuda como advém cada processo da palavra e, assim, aplica os resultados à teologia segundo dois critérios. O primeiro, que podemos chamar de "sistemático" quer unificar o domínio da teologia sob um único "Processo da palavra". O segundo, que chamamos "crítico", quer confrontar esse processo com a ciência hermenêutico-linguística. O Verbo fez-se carne, assim, fez-se linguagem, discurso, discurso humano. Por isso Ricoeur nos diz: "Que o Logos se torne discurso, seja elevado à categoria de nossa pala- 
vra [mots], é isso o Geschehen que cria o encontro entre a teologia da palavra e os estudos linguístico" (RICOEUR, 2015, p. 04).

Cada texto escrito é autônomo, distanciado e por essa razão é mudo. Cabe ao leitor lhe dar vida. Mas como pode isso acontecer? Recuperando o sentido. Assim como o autor é capaz de frisar, por meio da estrutura linguística a sua intenção pondo um evento de discurso sensato cujo sentido depende da estruturação linguística, do mesmo modo, mas inversamente, o leitor, através da técnica linguística busca um sentido no texto e, assim, constrói uma hipótese de sentido. Ele aposta sob a sua plausibilidade e convalida por meio dos procedimentos críticos a sua probabilidade.

$\mathrm{O}$ intérprete projeta um mundo do texto, o retém como possível e certifica de verificá-lo. Tudo isso é um novo evento do discurso no qual advém a fusão de horizonte. Horizonte esse que é aquele do texto, distanciado e exteriorizado na obra escrita, ou seja, aquilo do leitor que sempre é tocado.

Através do evento se passa ao sentido e do sentido ao evento sem, entretanto, recorrer a uma hermenêutica psicologizante. Essa dialética é fundamental para a teologia, como veremos, e permite a recuperação da teologia da história.

Pode-se perguntar, diante disso, quais são as contribuições que a filosofia da linguagem dá a uma teologia da palavra?

A filosofia da linguagem é diferente em três pontos de vista: linguística estrutural, fenomenologia da linguagem, ontologia da linguagem. $\mathrm{O}$ primeiro se baseia em três níveis da linguagem: a) distinção entre língua e palavra, prevalecendo ponto de vista sincrônico sobre o diacrônico, interesse pelas relações estruturais entre os termos, encerrados em cada elemento extraestrutural e em cada referência. $\mathrm{O}$ segundo sobre a fenomenologia da palavra que aborda a linguagem sob o ponto de vista da sua intenção de dizer algo e o terceiro, em uma ontologia do discurso que aborda a linguagem como uma forma de ser.

Pode-se dizer que, as contribuições da linguística estrutural para a teologia bíblica são várias e importantes para retirar toda imprecisão da exegese. Inconscientemente para quem fala, cada linguagem já determina a polissemia da palavra em um texto. Cada significação tem uma estrutura, uma referência. 
Aqui surge a necessidade de não misturar o ponto de vista sincrônico com aquele diacrônico da palavra. Para fazer isso, é necessária uma análise estrutural que clarifique o valor diferencial do termo no tempo.

A fenomenologia da linguagem coincide com a semântica, vê a linguagem, não como um sistema fechado de signos, mas como uma função da existência humana. $\mathrm{O}$ homem fala porque diz algo, pois entende algo e por isso se serve da mediação linguística para se referir à realidade e, de tal modo, diz algo de si. Em resumo, o problema do uso da língua, que comporta três momentos da linguística. São eles: significação, comunicação e expressão, sendo o primeiro o mais importante.

Essa fenomenologia afirma o primado filosófico da significação sobre os outros dois momentos. De fato, o homem representa o real com signos e é conhecedor do que sejam os signos. Isso responde ao postulado fenomenológico da intencionalidade que se distingue em dois momentos: o momento do sentido, dizer qualquer coisa e o momento da referência, dizer sobre alguma coisa.

A unidade linguística da semântica é a frase. É na frase que o evento da linguagem atualiza o sistema da língua e/ou situa-o na história, isso graças à pluralidade do vocábulo.

A teologia da palavra, na qual a revelação de Deus é o objeto da teologia irrompendo através da palavra, tem grande implicação na fenomenologia da linguagem. Primeiro porque a teologia se funda sobre a convicção de que a linguagem possa significar, exprimir e comunicar. Isso porque a comunidade cristã é uma comunidade é que interpreta o texto e não é interpretada.

A teologia recorre à polissemia e à metáfora, ao momento linguístico que a fenomenologia compreende e explica. A teologia da palavra recorre à fenomenologia da linguagem quando se trata de interpretar as palavras-chave sem parar de reinterpretar a partir dos recursos semânticos e culturais de cada época. A relação cultura-semântica é objeto de contribuição da fenomenologia.

No que diz respeito à ontologia da palavra, esta procura pela potência da palavra ou a raiz ontológica da palavra na estrutura do próprio ser. Se a linguagem é mediação, então é certo que "não pode ser o ponto de partida, esse sobrevém em um processo de existência que o precede e o envolve. Esse 
processo de existência em seu sentido que torna a linguagem possível como evento humano fundamental" (RICOEUR, 2015, p. 14).

Se, entretanto, a linguagem é mediação, então o ser pode ser mediado. Depois, o ato de dizer é uma modalidade do ser. Ricoeur afirma tudo isso seguindo Heidegger na passagem do "dizer" ao "falar" até a afirmação do silêncio e da escuta como posicionamento ontológico fundamental, posicionamento poético de abandono e no conjunto da criação. A teologia está inserida nessa ontologia, visto que a noção de Revelação requer a noção de abertura, de desvelamento do ser na palavra.

Isso não significa que o Cristo, como Palavra, dilua-se em uma espécie de revelação geral, mas ao contrário: a unicidade do Cristo funda e recolhe todas outras figuras da manifestação do ser na palavra.

Se se crer que o Verbo se fez carne, reconhece-se, então, a universal manifestação do ser na linguagem, pois tem-se indícios dessa manifestação, na linguagem poética, profética.

Há uma outra implicação entre a teologia bíblica e a ontologia da linguagem. Ela está em relação com a palavra de Deus e outras palavras-chave como é o caso: criação, pecado, graça. A palavra Deus e essas últimas estão em relação recíproca, de modo que a palavra Deus é o centro de gravidade de todas as outras palavras.

Não se distorce o pensamento de Ricoeur se dissermos que a obra da analogia fidei que é muito mais rica e mais profunda que a da analogia entis. De modo que Ricoeur pensa que de Deus se possa falar somente por meio e no âmbito da analogia fidei. De tal modo, a palavra "Deus" tem mais sentido de que a palavra esse. Primeiramente, porque acolhe em si todos os valores do simbolismo religioso de todos os tempos e culturas, que possam ignorar o conceito de esse. Essa palavra se funda no simbolismo da cruz, do amor gratuito até o sacrifício que não pode ser presente no conceito de esse, que na melhor das hipóteses, como diria Heidegger, o milagre do ser que não vence nada.

$\mathrm{O}$ ato de Deus é, desta forma, ato de bondade que o homem acolhe, pois não há um indício da vitória do ser sobre o nada. Esse ato é, assim, ato de palavra, a palavra é o centro da fé cristã. 


\section{A Revelação e Testemunho: pensar e o recuperar a experiência humana a partir do símbolo}

$\mathrm{Na}$ hermenêutica ricoeuriana se destacam dois aspectos em relação aos textos que falam do referencial "Deus", são eles: a Revelação e Testemunho. Definir um texto como revelado é a tarefa da teologia que se aplica ao texto contribuindo para ressaltar a presença de Deus que se revela e procura reconduzir a experiência humana que dessa vem renovada. Contudo, refletir sobre a experiência humana que esses textos nos trazem é tarefa do filósofo, ou seja, ele nos faz notar como as duas categorias acima citadas renunciam o abandono da consciência subjetiva e ocupam uma posição estratégica similar à categoria do poético em sua vertente objetiva.

Ricoeur quer buscar "um conceito de revelação e um conceito de razão que, sem nunca coincidir, podem pelo menos entrar numa dialética viva e promover juntos algo como uma inteligência da fé" (RICOEUR, 2011, p. 146). Trata-se, portanto, de uma pesquisa, muito embora Ricoeur afirme que isso não é tarefa do filósofo nem do teólogo, mas daquele que busca compreender melhor como ser crente, compreendendo melhor os textos de sua fé.

Para Ricoeur, a revelação é polissêmica, polifônica e consiste na coisa do texto, na qual é superada cada conexão psicologizante da inspiração, que se explica na dialética entre evento histórico e evento da palavra: "a força das coisas dita que move o escritor. A coisa pede para ser dita, eis o que é revelado analogicamente pela expressão do símbolo de Niceia: Creio no Espírito Santo [...] que falou pelos profetas" (RICOEUR, 2013, p. 168).

Em Ricoeur o mais importante não é o fato em si, mas o fato vivido pelo homem e, por conseguinte, a sua dimensão poética, ao mesmo tempo receptiva e ativa, cuja dimensões e características dependem do tipo de trabalho expressivo com o qual se manifesta.

Cada gênero literário comporta uma experiência diversa. Para Ricoeur, o evento é realizável somente no momento que se coloca um outro evento interpretativo, a partir do sentido e do significado, os quais encontram individuações próprias no gênero literário e no seu estilo. Apesar disso, nosso filósofo, afirma 
que a revelação, em qualquer uma de suas modalidades, não se deixa incluir e dominar em um saber. A respeito disso, a ideia de segredo é a sua ideia-limite.

O Deus da Revelação é um Deus que se mostra e se oculta. Na verdade se mostrando se esconde como diz Ex 3,13-15 que vê na revelação do nome o inominável. Deus liberta, Deus cria o povo, contudo Ele não se define. Dessa questão, Ricoeur deduz que nem o conceito onto-teológico de Deus como ser e como providência pode exaurir a revelação; E que essa não pode mais constituir um corpo de verdade que uma instituição possa dispor visto que Deus não pode ser alcançado através dos instrumentos da verdade objetiva que respondem a critérios da falsificação e da verificação.

Além disso, a verdade de Deus não é um produto do Cogito, mas para o que crê, ele existe. Se ele existe, como algo que se manifesta, através da linguagem religiosa, Ricoeur se pergunta se não existe no homem uma experiência a-religiosa da manifestação, na qual, quaisquer que sejam as condições de possibilidade, essas possam ser aplicadas a Deus.

Nesse preciso ponto, a hermenêutica filosófica vem ao encontro da teológica. De fato, a poética apresenta a experiência de manifestação e hermenêutica. $\mathrm{Na}$ análise do texto bíblico Ricoeur aplica cinco teses que fundam a teoria do discurso: 1) a linguagem como discurso; 2) discurso como obra estruturada; 3) relação palavra-escritura; 4) obra do discurso, texto, como projeção do mundo e 5) discurso mediador da auto-compreensão. Cada etapa da interpretação corresponde a uma modalidade específica de intepretação.

A linguagem como discurso, o discurso oral, é marcado pelo distanciamento. Esse distanciamento se insere na dialética entre evento e singnifcação. pois "o discurso se dá como evento: algo acontece quando alguém fala" (RICOEUR, 2008, p. 46). O discurso é um acontecimento que se realiza no presente. No discurso alguém fala e, então, exprime-se. O discurso não é algo vazio, ele esta ligado a algo que ele procura descrever, representar ou exprimir. $\mathrm{O}$ discurso é impessoal, pois se dirige a outro que em sua ação pode ouvi-lo, interromper, ou destacar determinadas coisas desse discurso. $\mathrm{O}$ discurso, desta forma, o discurso está em um evento, esse é a vinda à linguagem de um mundo mediante o discurso. $\mathrm{O}$ discurso é evento na atualização de nossa competência linguística. 
O discurso tem uma característica marcante, que é a superação do acontecimento presente na significação. A significação comportar e abrange as exteriorizações das intenções contidas no discurso e torna possível uma explicação do discurso.

Para Ricoeur,

a linguagem efetua-se como discurso. $\mathrm{O}$ discurso efetua-se como obra estruturada. Há uma relação entre fala e escrita no discurso e nas obras de discurso. A obra de discurso constitui uma projeção do mundo. O discurso e a obra de discurso constituem mediação da compreensão de si (RICOEUR, 2008, p. 45).

O discurso, assim, como obra tem três traços: totalidade finita pela composição de frases, nesse ponto Ricoeur, nota que a "obra literária é o resultado de um trabalho que organiza a linguagem" (RICOEUR, 2008, p. 51); a obra é codificada em um gênero literário e por último um estilo que liga o indivíduo a toda obra. Essas três características são critérios, ou melhor, caminho para a compreensão daquilo que quer ser dito no discurso. Essas características da obra nos mostra como se pode ter uma compreensão do evento que se dilui no tempo e o sentido que permanece como é o caso da Ressureição. Há um evento, a Ressureição do Cristo, essa se dilui temporalmente, mas permanece o sentido de que, também, eu poderei ressuscitar. Ou seja, remete o indivíduo que escreve e que escuta a obra na própria obra, na própria individualidade da obra, através das estruturas do gênero literário, pois o "discurso não se dá alhures: ele se verifica nas estruturas da obra e por elas"(RICOEUR, 2008, p. 52).

Existe uma relação entre fala e escrita, quando se escreve algo, esse escrito torna-se independente do autor. Certamente, do falar ao escrever há uma falta de harmonia, entre o que o autor quis dizer e o significado expresso pelo texto. Ricoeur nos diz que "o texto deve poder, tanto do ponto de vista sociológico como psicológico, descontextualizar-se de maneira a deixar-se recontextualizar numa situação nova: é o que faz, precisamente, o ato de ler" (RICOEUR, 2008, p.119). Isto é, o texto transcende o seu autor, permitindo novas interpretações. 
Ricoeur nos coloca uma noção importante que é a do mundo do texto "mundo do texto" é a saída: a tarefa hermenêutica fundamental escapa à alternativa da genialidade ou da estrutura. Vinculo-me à noção do 'mundo do texto"' (RICOEUR, 2008, p. 57).A pergunta de Ricoeur é no que é que se torna uma referência quando o discurso vira texto?

O ponto de partida é a manifestação do mundo por parte do texto e da escritura. Esse ponto de partida deve ser um ponto de vista hermenêutico-filosófico, pois as religiões da proclamação são religiões do livro, do texto. Dessa forma, o filósofo deve analisa a linguagem religiosa contida nos textos para coloca-la em relação de proximidade do discurso filosófico, o discurso kerygmático e teológico. Pois, se existir "um logos, o logos de Cristo apenas me pede, enquanto filósofo, uma mais completa e mais perfeita realização da razão; nada mais do que a razão, mas a razão inteira” (RICOEUR, 1999, p.392).

A pregação cristã se fixa na escritura estabelecendo o cânone e, consequentemente, delimitando e esclarecendo o seu âmbito hermenêutico. O que permite a passagem da palavra à escritura é o fenômeno da distanciação. Ele permite passar da escritura à palavra, ou seja, à transmissão da mensagem. Como o próprio Ricoeur diz: "graças à escritura a palavra chega a termo a nós, unindo-se a nós, não mais pela 'voz' de quem a pronunciava, mas através do 'significado'e da 'coisa"' (RICOEUR, 2013, p. 88), enquanto o escrito é autônomo a respeito do locutor. Graças à escritura a sua distanciação assume o primeiro posto, o mundo do texto em detrimento daquele do autor. A palavra se torna algo que pode ser trabalhado, ou seja, um conjunto exteriorizado, que tem um "mundo", um mundo do texto, que não é o sentido da obra, mas a sua referência, pois, "não é o que é dito, mas sobre o que isso diz" (RICOEUR, 2008, p. 39).

Tudo isso diz respeito às três funções do discurso poético: a) autonomia da escritura, b) a exteriorização por meio da obra e c) referência ao mundo. Por meio dessa tríade temos uma base para o discurso poético que traz algo de específico, ou seja, suspende a referência descritiva, do objeto, para abrir-se a uma referência duplicada, que mostra ao homem a sua pertença ao ser. No discurso poético o homem rompe a habitual figuração que o coloca e o projeta a manifestar a sua pertença ao ser. 
A linguagem poética revela o ser-no-mundo do homem, que não pode ser conhecido objetivamente. Ricoeur fala, então, de revelação, pois não se trata de uma verdade de adequação, mas de uma verdade como escuta e manifestação: o ser e a participação do homem no ser.

A revelação dada pela poética corresponde à interpretação, que se dá como evento de discurso e que implica no reconhecimento da modalidade de ser-no-mundo projetada pelo texto. Essa é fictícia e, consequentemente, distanciada da realidade quotidiana.

Ricoeur aplica esse conceito não religioso à Bíblia e faz com que a hermenêutica filosófica seja aplicada a hermenêutica teológica. É compreensível que a Bíblia, enquanto texto escrito, siga as mesmas regras de cada texto escrito. Como resultado, a hermenêutica geral ou filosófica é o instrumento que deve se aproximar do texto inspirado para dele sacar o seu significado. Isso se dá porque "a tarefa primeira da hermenêutica não é suscitar no leitor uma decisão, mas permitir, antes de mais nada, aquele modo de ser que existe na 'coisa' do texto, de alargar-se" (RICOEUR, 2013, p. 90).

Cabe dizer que, inicialmente, a hermenêutica teológica não mais esquece de ser teologia da palavra e da escritura. Também não pode descuidar em ver que o evento do discurso que interpreta é ligado ao nascimento do sentido a partir da estrutura linguística. Dessa forma, ocorre um espaço hermenêutico que possibilita o surgimento da hipótese de sentido, ou seja, convalidação da hipótese de sentido como um trabalho de reflexão sobre um novo projeto de mundo. Assim podemos notar que, dentro dos critérios vistos, existem alguns que se destacam: afinidade entre forma do discurso e mundo, a realização entre as várias formas do discurso no interior da obra e a relação entre configuração total do corpo literário e o espaço interpretativo, que está aberto a todas as formas de discurso.

Ao analisar o discurso profético, Ricoeur percebe que o primado pertence à coisa dita pelo profeta e não à inspiração do narrador. Ele também percebe a correspondência entre linguagem poética e religiosa, sobretudo a correspondência, segundo a qual, a coisa do texto bíblico é capturada indiretamente, por 
meio de uma referência duplicada que mostra o mundo do nosso enraizamento originário. Essa referência vem através de nossa experiência ordinária.

A Revelação consiste no fato que a Bíblia manifesta um ser novo, dado pelo texto, a partir da experiência ordinária e, ainda mais, superando-a. Por isso a Revelação é um traço, uma característica do mundo bíblico. Conforme, diz o nosso filósofo: "Ousarei, portanto, afirmar que a Bíblia é obra revelada na medida em que o ser novo de que se fala é o seu momento relevante a respeito do mundo e de toda realidade, isso inclui meu mundo e minha história” (RICOEUR, 2013, p. 90-91). Assim, o ponto de partida da releitura e da reflexão ontológica de um texto bíblico é a poética.

Essa complexa realidade se desenvolve diante do texto. Contudo, é a partir do texto que podemos invocar o ser novo que é projetado pelo texto e que reinterpreta toda experiência humana. Dessa forma, Ricoeur não pode mais englobar um traço específico da linguagem religiosa. Isto é, que o referente Deus circule entre os mais diversos discursos como a profecia, a narração, a prescrição, a sabedoria, o salmo, coordenando esses diversos discursos dando-lhes um ponto de fuga, um índice de incompletude.

A relação entre hermenêutica filosófica e teológica pode ser explicada no momento que se percebe que essa relação não pode ser reduzida àquilo que chamamos de hermenêutica geral e hermenêutica particular. Pois, a Bíblia é um dos escritos que relatam a existência humana, mas é único, pela via de referência ao Nome do Inominável. Essa via exige uma hermenêutica única que se serve da hermenêutica filosófica como instrumento. A teologia constitui um ponto de vista epistemológico que parte do particularismo de seu objeto, Deus e de sua palavra, como também de modos expressivos em que tal palavra se exprime e que são objetos da ciência do homem.

Essa relação e muito complexa, mas de uma via única. A hermenêutica é o âmbito comum que permite o encontro entre a filosofia e a teologia. Não só a filosofia nos oferece muitas vezes respostas, mas a fé muitas vezes é que interroga. Os evangelhos são testemunhas da utilização de um recurso desestabilizante em relação aos interlocutores. É um binômio de convicção e critica, que nos mostra que a filosofia não é simples- 
mente crítica, pois ela é também da ordem da convicção. Por sua parte, a convicção religiosa tem em si uma dimensão critica interna. Contudo, a aproximação entre ambas, não dispensa a diferença fundamental entre um discurso que vive do dado da fé, que dá uma palavra que regenera o mais profundo do ser e um discurso que deixa em suspenso a nominação de Deus, se mantendo no ascetismo da argumentação. De um modo diverso, os dois discursos tem um equivalente práticos nas relações que se dá entre a lógica de equivalência e a lógica de dom. entre o poético e o ético.

O mundo bíblico é apreendido nas suas múltiplas dimensões, correspondentes aos gêneros literários, sem privilegiar nenhum e, assim, não deixando que se forme nenhum esquema sistemático predominante. Isso é o que Ricoeur chama de circularidade dos símbolos, onde um contradiz e corrige o outro sem reduzir a experiência originária que é a raiz última da superabundância inexaurível do símbolo. Com os símbolos sempre voltam aos símbolos primários em uma segunda navegação, assim ocorre sempre voltar à confissão de fé.

O mundo do texto bíblico abre a realidade cotidiana, vencendo o enclausuramento e, desse modo, um contínuo transcender da cotidianidade, a qual fornece o esquematismo da superação da mesma. Em razão disso, "a forma de projeção do mundo bíblico se manifesta conforme a ruptura e abertura, e depois também essa projeção do mundo deve ser reconhecida como dimensão poética no pleno significado da palavra como é feito pela coisa do texto" (RICOEUR, 2008, p. 45). Pode-se dizer que a Bíblia, dentro de o que foi falado, como texto a ser explorado pela hermenêutica filosófica, abre, assim, como a poética, uma possibilidade dada, que permite transcender aquilo que foi escrito.

A proposta de Ricoeur é que se leia o texto sagrado como se fosse um livro qualquer. Contudo, ao final "se descobre que o livro é a Palavra de Deus. Essa descoberta guarda o ser novo, anunciando a si mesmo, a sua qualidade" (RICOEUR, 2008, p. 45). Esse ser novo é resultado do "distanciamento" de cada realidade cotidiana. Essa distanciação prossegue e radicaliza aquela realidade cotidiana operada pela referência poética do mundo do texto. 
Se, porém, Deus é o referente último e inatingível do mundo do texto bíblico, é certo que a referência do conceito de ser não pode ser adequada à Deus, pois "compreender a palavra de Deus significa seguir a flecha, a indicação significante, e o seu duplo poder de recolher os significantes que brotam dos discursos e de abrir um horizonte que foge pela finitude do discurso" (RICOEUR, 2008, p. 67).

A hermenêutica teológica, sempre esclarecida pela filosófica, deve ter por tarefas fundamentais: a leitura e estruturação do referente dos textos bíblicos, assim como, buscar encontrar uma totalidade, colocá-la em ordem, ligá-la aos vários símbolos e confrontá-la com a experiência do crente.

Assim Ricoeur ao abordar um tema que toca também a teologia, buscando analisar a fenomenologia dos símbolos procura mostrar uma coerência entre os mesmos; pois é a hermenêutica de cada símbolo ou mito que me permite entender o que eles me dizem e a tarefa da filosofia é a que consiste em pensar a partir do símbolo. Nesse momento, faz-se toda uma redescoberta da experiência humana à luz da revelação dada pelo símbolo.

Cabe agora ver a hermenêutica do testemunho, que corresponde à temática da apropriação. Sobre essa, Ricoeur tem por base dois problemas fundamentais, a saber: o problema da dupla reapropriação, como o homem faz sua interpretação daquilo que ele interpreta, e o problema da contingência histórica do evento.

O testemunho reúne todo alcance na questão de Deus e, diretamente, na relação que se tem entre experiência do absoluto e a ideia de absoluto, por isso, o testemunho não pode ser um saber absoluto. Tudo isso é mostrado através dos fatos, exemplos, símbolos que estão no tempo e que são superados pelos eventos singulares. Tais eventos são contribuições de testemunho do absoluto.

O problema para Ricoeur é responder ao problema do absoluto que se exprime na experiência como "testemunho absoluto do absoluto" (RCIOEUR, 1994, p. 105). E, ainda: se o testemunho deve se pôr como problema filosófico e não só jurídico e histórico é na medida em que a palavra não se limita a designar a narração de um testemunho que se refere, mas se aplica à palavra, à obra, ação, vida que, enquanto tais atestam o coração da experiência e da história, uma intenção, uma inspiração, uma ideia que sobre passa a experiência e a história. 
Para haver uma experiência do absoluto o homem deve ter algo dentro de si que lhe permita reconhecê-la. Esse algo está em uma conjuntura interior da afirmação originária e na exterioridade dos atos na qual existem todos os caracteres de uma afirmação absoluta do absoluto.

Essa afirmação originária não é representável nem muito menos conceitualizável. Ela não pode ser uma experiência. Ela somente é ato que leva a cabo a negação das limitações que tocam o destino individual. Ela é dépouillement. O problema do testemunho consiste, no nível existencial, em uma possibilidade de chegar aos sinais que o absoluto dá de si na história e que, todavia, é pertinente à consciência do homem em sua necessidade de compreender-se como sujeito livre. Essa afirmação originária é um ato puramente interior, inexprimível ao exterior, enquanto recusa.

É graças ao desvelamento que o homem em cada ato pode chegar a captar os sinais do absoluto. Esses se doam, não como pensamentos do incondicionado, mas como testemunho. Porque é no testemunho que podemos captar tais sinais? Ricoeur nos mostra através de um elenco de noções insuficientes, que dão a oportunidade de fazer uma fenomenologia do testemunho. Essa noção nada mais é que aquele do exemplo e do símbolo.

A fenomenologia é insuficiente, pois no exemplo é perdido o singular para afirmar a regra, ordem sistemática que não garante a contingência histórica, mas busca reduzi-la a um momento sistemático. A segunda é insuficiente para explicar a experiência do absoluto, pois o símbolo, sendo opaco, não é sistematizável: "O seu sentido é o mais importante da sua historicidade. Como tal, constitui-se, mais uma categoria da imaginação produtora” (RICOEUR, 1994, p. 137). O símbolo é mais próximo da manifestação do sagrado e do sentido, enquanto o testemunho é mais próximo à proclamação e ao evento.

No sentido jurídico, o testemunho é uma prova a favor ou não para influenciar um juízo e ligá-lo a uma decisão. Essa decisão não é de todo vinculada ao testemunho. Pode ser, também, falsificado de fatos subsequentes, valores ascritos do testemunho.

Outro sentido do testemunho indica a defesa pública de uma profissão de uma conviç̧ão, ou melhor, funda seu comportamento sob quem fala, confissão. 
No uso religioso, o testemunho é sempre um envio que não testemunha sobre fatos contingentes, mas sobre o sentido global da existência humana renovada por Deus. $\mathrm{O}$ crente deve proclamar e difundir esse testemunho com total conviç̧ão de sua pessoa. Então, o testemunho, como elemento novo, ele procede de uma iniciativa absoluta, tanto na origem como no conteúdo.

Ricoeur se pergunta sobre o problema hermenêutico do testemunho se é possível que a filosofia da reflexão absoluta encontre no evento ou atos perfeitamente contingentes, a atestação que o injustificável é superado aqui e agora? Se existe o direito de investir de um caractere absoluto um momento da história?

O problema em conciliar o absoluto, inexprimível, da afirmação originária com a exterioridade dos eventos do testemunho do absoluto, passa, para Ricoeur, por uma filosofia da intepretação. O Cogito é mediado por um universo dos signos e, assim, existe uma noção reflexiva dessa mediação que deve perder-se para encontrar-se.

A reflexão é a apropriação de nosso esforço de existir e do nosso desejo de ser. Assim, a reflexão é interpretação dos sinais pelo homem, de forma, que se requer uma hermenêutica e não uma eidética.

Essa hermenêutica implica em assumir o conceito de pertença. O homem se dá conta da pertença através, da tradição, da cultura graças ao fenômeno da distanciação que faz com que o homem tome consciência do mundo.

Um outro modo de pertença é determinado por uma auto-compreensão diante do texto, ou seja, uma apropriação do mundo do texto como interprete. Esse autocompreender-se do texto é um momento essencial da hermenêutica. Ele não é uma apropriação do texto por uma "congenitalidade", mas por uma distanciação pela obra e pelo mundo. Esse distanciamento abrange cada leitura, que é lúdica, desenvolvendo as variações imaginativas no leitor. Esse transforma o mundo baseado na transformação do "mim" e vice-versa. Graças à distanciação pela escritura, o homem pode exercitar a suspeita da ilusão.

A poética é a arte de compor tramas, pois “a trama é a representação da ação" (RICOEUR, 1977, p. 88). A intenção do poema será a mímesis da ação humana. $\mathrm{O}$ poeta ao compor um mythos (fábula ou intriga) oferece uma 
mimesis praxeôs (uma imitação criadora dos homens atuantes. Uma identificação entre ficção e representação do real.

A noção de mythos é o fio condutor da indagação de Ricoeuriana, tanto na ordem da história como na ordem da ficção, será uma diferenciação na mímesis o que permite distingue os níveis de sua empresa. Existem três mímesis para Ricoeur:

A mímesis $I$ - a compreensão da prática da ação em um nível hermenêutico é uma pré compreensão da ação, ou seja, implica que, apesar da ruptura que há entre a literatura e a força da novidade que está na composição poética, ela permanece incompreensível se não se configura ao que tem figura na compreensão humana, pois "a composição da trama é enraizada em uma pré-compreensão de um mundo da ação: e suas estruturas inteligíveis, em uma simbólica e de seu caráter temporal" (RICOEUR, 1977, p. 87).

A trama (intriga) sendo a imitação da ação, requer-se que a ação possa ser identificada em suas estruturas. A semântica da ação nos permite compreender a rede conceitual que distingue o campo da ação dos movimentos físicos.

Existe para Ricoeur, tanto uma pressuposição e uma transformação. $\mathrm{Na}$ primeira, a narração faz uso de termos da rede conceitual. $\mathrm{Na}$ segunda, adiciona os recursos discursivos que dão a estes termos uma significação efetiva, graças ao encadeamento que confere a trama.

A compreensão narrativa encontra um segundo lugar, a de evidenciar os recursos simbólicos da ação. A ação tem uma função intricadamente simbólica, no sentindo médio do símbolo. Essa utiliza alguns dos símbolos de natureza cultural que tem um caráter público, como se fosse um texto, que significa isso ou aquilo, como o acenar como a mão que pode ser para chamar um táxi ou para despedir-se. A ação utiliza-se, assim, de regras e códigos que não como em regras de comportamento, ela se utiliza das normas prescritivas que, no interior de uma cultura, como é o caso da cultura bíblica permite julgar o valor de uma ação, segundo a escala de preferência moral. Assim, o sistema simbólico proporciona um contexto no qual descreve as ações particulares e confere à ação sua primeira legibilidade. 
Existe ainda uma ação que concerne ao caráter temporal. Uma fenomenologia da ação pode ser ligada a análise existencial de Heidegger, na medida em que essa análise pode ser considerada como uma antropologia filosófica. Tanto a rede conceitual como as articulações simbólicas da ação são portadoras de recursos e estruturas temporais que explicam a capacidade da ação para ser contada. Essa é uma grande vantagem para superar a dicotomia entre a relação sujeito/objeto, rompendo o primado da consciência pelo objeto e esculpindo a estrutura fundamental do cuidado como ser-no-mundo. Uma das características principais do cuidado é a intratemporalidade que é o terceiro nível em uma organização hierárquica da temporalidade, cujo primeiro nível é a temporalidade e o segundo a historicidade. O beneficio dessa temática heideggeriana consiste no fato que a intratemporaridade é irredutível à representação linear do tempo e assinala o primado do cuidado no confronto da coisa. Não são as coisas de nossa preocupação, mas é o cuidado que determina o sentido do tempo, pois sobre o pedestal das intratemporalidade se edificam as configurações narrativas e as formas mais elaboradas que lhes correspondem.

Ricoeur nos mostra que a literatura não será capaz de ser compreendida, se não se configurar a uma ação humana prefigurada. Assim, nosso filósofo, nos diz que a mímisis I é enucleada, na compreensão da ação, pois "imitar ou representar a ação é, em primeiro lugar, pré-compreeder o que é o agir humano: sua semântica , sua simbólica, sua temporalidade”(RICOEUR, 1977, p. 112).

A mímisis II ou a compressão narrativa como tempo configurado, esse é o nível da mediação entre a mímisis $i$ e a mímisis $i$, por isso se fala em meio a trama e não simplesmente da trama. Na trama ao se extrair uma história de uma série de acontecimentos, transforma esses em uma história. Por essa reciproca, o acontecimento não é uma mera ocorrência, mas contribui para a trama e a história não é uma mera enumeração de acontecimentos, mas uma organização inteligível. A trama toma todos os fatores em uma única história e a configura em uma totalidade dando concordância a discordância.

Sendo a trama uma mediadora por causa de seu caráter temporal. Toda narração combina uma cronologia e uma não cronologia, a primeira é episódica a segunda configuracional. $\mathrm{O}$ ato configurante junta os diversos incidentes 
e consegue a unidade de sua totalidade temporal. A composição de uma história é, do ponto de vista temporal, extrair uma configuração de uma sucessão.

$\mathrm{Na}$ mimisis III ou a compreensão narrativa dentro de um tempo reconfigurado, Ricoeur mostra que é nela há a intersecção

entre o mundo do texto e o mundo do ouvinte: a intersecção, portanto, entre o mundo configurado pelo poema e o mundo no qual a ação efetiva se desdobra e desdobra sua temporalidade especifica (RICOEUR, 2009, p. 123).

Ricoeur coloca quatro etapas: que existe um encadeamento das três mimisis que mostra uma progressão e não uma mera circularidade; o ato de leitura em seu dinamismo está atrelado ao ato configurante; esborçar as dificuldades da noção de referencia no sentindo da ordem narrativa e por último, indicar que ajuda pode se esperar da hermenêutica do tempo narrado e da fenomenologia do tempo.

Visto esses três estádios da mimisis é necessário voltarmos a questão do testemunho e da revelação dentro da linguagem religiosa.

O momento hermenêutico mais importante para a teologia é "a fé constituída pelo novo ser que existe pelo texto" (RICOEUR, 1976, p.34). Certamente, a fé é um ato irredutível à linguagem, pois é sempre um risco com a qual a hermenêutica inicia e termina. Entretanto, a fé exige uma intepretação para encontrar-se.

Ricoeur nos diz que:

A fé bíblica existe baseada sob a interpretação constantemente renovada dos sinais-evento relatados pela Escritura, seja no êxodo no Velho Testamento, seja a ressurreição no Novo Testamento. Esses são os eventos de libertação que abrem e fecham a extrema possibilidade da minha liberdade e, consequentemente, vem a mim pela Palavra de Deus (RICOEUR, 2013, p. 11).

Graças à apropriação do texto como autocompreensão diante do que foi dito, é possível desmantelar por meio da hermenêutica redutora os prejuízos que se insinuam na intepretação do texto bíblico. Esse desmantelamento per- 
mite abrir-se à imaginação de novo ser, segundo a linha do mundo do texto, criticamente procurada.

A hermenêutica do testemunho presume dois atos: $\mathrm{o}$ ato de consciência sobre si mesmo e um ato pela compreensão dos sinais que o absoluto dá. Assim, os sinais do absoluto são os mesmos com os quais a consciência se reconhece, pois: "a hermenêutica do testemunho consiste na convergência desses dois movimentos, dessas duas exegeses, exegese de si mesmo e exegese dos signos exteriores" (RICOEUR, 2011, p. 189). Essa convergência vem, de um lado, porque o testemunho requer uma retomada reflexiva e, por outro, que a afirmação originária desenvolve uma interpretação do tipo reflexiva, em ambas os resultados coincidem.

Cada testemunho doa algo para a interpretação, assim, dá início ao ponto de partida de cada reflexão. O Cogito, que não é criador, exige uma imediatez que o manifesta. $\mathrm{O}$ absoluto, por conseguinte, deve se mostrar para ser compreendido. Não obstante, o testemunho requer ser interpretado, primeiro, porque é atravessado pela dialética sentido-evento. Cada testemunho vem juntamente com uma confissão e uma narração. A interpretação desses é sempre possível, pois existe sempre a possibilidade de preencher a lacuna entre evento e sentido com um outro sentido que interpreta a sua relação. Segundo, o testemunho requer uma interpretação, pois suscita uma atividade crítica. Nem sempre o testemunho é verdadeiro, e se o é depende de um juízo. Diante do testemunho sobre o absoluto nossa atitude é aquela de crer na narração, mas igualmente de fazer um processo para o absoluto, uma crítica ao testemunho. Ou seja, estabelece se isso é um ídolo ou sinal, uma criteriologia do divino.

Por fim, o testemunho exige uma interpretação por causa da dialética do testemunho e da coisa vista. Se por um lado o testemunho procede da coisa vista, por outro esse procede pelo envolvimento do próprio testemunho, a prova de sua conviç̧ão. Aí é nesse sentido, o testemunho não é somente narração da coisa vista, mas afirmação da sua vida ou da sua verdade.

Para Ricoeur, existem três etapas dialéticas do testemunho em direção a uma reflexão que renuncia ao domínio da consciência, o caminho que leva da afirmação originária ao testemunho. 
A primeira etapa se diz da dialética do evento-sentido, nós existimos, pois somos atingidos pelos eventos. Esses eventos, mesmo fortuitos, mudam nossa vida. Eles são diversos dos eventos fundadores que ligam o sentido da nossa existência.

A segunda etapa é o do falso ou verdadeiro testemunho. Nessa a afirmação originária é mudada em criteriologia do divino, pois o homem se apropria da afirmação somente de modo crítico e reflexivo por causa da nossa existência finita. Para acolher o absoluto, do qual não há uma afirmação direta, sucede selecionar os predicativos divinos, que não são a qualidade do ser em si, mas expressões múltiplas e diversas de um Ato que pode vir pela linguagem, compreendendo-se como qualidade, mas que não forma um sistema fechado, pois restam somente elementos descontínuos de um esforço nunca completo.

A criteriologia do divino não é um sistema fechado do divino que tem que dar conta de tudo, mas surge do cruzamento de dois atos irredutíveis: o ato pelo qual o homem encontra uma qualidade do divino e a testemunha. Nesse testemunho, a cada qualidade que se dá o nome de divino corresponde "a um ato interior pelo qual nós o concebemos e falhamos, ao mesmo tempo, em realizá-lo e encarná-1o" (RICOEUR, 1994, p.134). Esse é, então, o segundo ato pelo qual a consciência busca abstrair sua limitação e encontra a pureza da sua intenção. É, portanto, um ato utópico. Nesse segundo ato, o homem busca verificar por si e sobre si o primeiro ato.

O primeiro ato é um contínuo transcender e atesta a irredutibilidade da afirmação originária e a sua não representabilidade. No segundo, ocorre uma esquematização e reflexão, atestando, assim, a necessidade de adequação. Existe aí um círculo hermenêutico.

Diante do divino, que é testemunhado na história, existe uma dialética de acolhimento do testemunho e da formação de uma criteriologia do divino, de modo que "formando os predicados do divino desqualificamos os falsos testemunhos; reconhecemos os verdadeiros testemunhos identificamos os predicados do divino" (RICOEUR, 1994, p. 192).

Desta forma, surge a terceira etapa, a do desenvolvimento do testemunho. O homem pode abrir-se ao testemunho somente aceitando renunciar a ser a fonte de sentido e, desta forma, produzir a dupla operação vista. 
Sobrevém que Deus se manifesta na história sem que essa o objetive. Dá-se também, renunciar a consciência soberana que quer fazer-se isoladamente. Essa renúncia coincide com a aceitação da dependência da consciência pela manifestação histórica do divino.

Nesse círculo, a anterioridade pertence ao testemunho histórico sob a consciência de si, entretanto, existe uma pré-compreensão não reflexiva pelo testemunho, ou seja, uma imaginação que dá a pensar o conceito, uma imaginação esquemática e crítica.

É, precisamente, nesse ponto que a desapropriação da consciência está diante do divino, seja diante da história e a necessidade da reflexão a partir dos sinais.

No testemunho temos uma apresentação histórica da nossa afirmação original, que nos deixa a esperança nos eventos testemunhados pelos textos. Esperança essa que necessita da mediação da linguagem para manifestar os seus figurativos

Certamente o testemunho diante de uma perspectiva da esperança esboçada pelos atos não nos conduz a um saber científico, mas chega ao provável de um testemunho que desencadeia ou não em uma promessa. Ele é sempre válido, pois se não responde ao modelo científico-objetivo da verdade, responde, ao menos à experiência da afirmação originária que a sustenta. A probabilidade do testemunho é aquela ligada a uma escolha uma decisão da experiência mais íntima pelo homem (o mal, a falta, a queda, o desvio) que exige uma expressão. Essa é sempre inadequada para manifestar a experiência.

\section{A palavra e a demitologização}

No âmbito da palavra, o Todo-Outro surge como elemento interno da dialética, de que já falamos, arqueológico-teleológica como arché e telos sempre além, como um horizonte de início e fim, pois "a linguagem é a única expressão integral, exaustiva e objetivamente inteligível da interioridade humana" (RICOEUR, 1977, p. 419).

O movimento da fé que vai da compreensão até a dialética da reflexão, busca o instrumento de sua expressão. É nesse ponto que Ricoeur diz que "a 
questão da fé se torna uma questão hermenêutica. Pois aquilo que se aniquila em nossa carne é o Todo-Outro como logos" (RICOEUR, 1977, p. 433).

Quando Ricoeur afirma que não há um saber absoluto e que o sagrado toma seu posto, ele o diz quando disso dá a pensar de modo sempre irredutível, colocando em xeque a razão e mostrando seus limites. $\mathrm{O}$ motivo dessa limitação é o mal, o qual introduz pelo evento do sentido um não sentido incompatível, incompreensível.

Ricoeur coloca o símbolo do mal em primeiro plano, pois resiste

a qualquer redução a uma consciência racional; é o fracasso de toda teodiceia, de todos os sistemas que resguardam o mal e testemunham o fracasso do saber absoluto no sentido hegeliano. Todos os símbolos dão a pensar, mas os símbolos do mal mostram de modo exemplar que nos mitos e nos símbolos sempre existe mais coisa que em toda a nossa filosofia (RICOEUR, 1977, p. 423).

Os símbolos do mal falam sobre o fracasso da nossa existência e nosso saber. Eles constituem o perene retorno à simbólica, isto é, pensar a partir do símbolo e segundo o símbolo. Esse pensamento ricoeuriano é sintetizado pelas três formulações: a despeito de, graças a e mais forte razão. Essas atestam que o sagrado se manifesta no símbolo que é objeto da filosofia da reflexão, fazendo-o cifra do eschaton que se dá no símbolo.

O símbolo é a resposta à oposição entre Hegel e Kierkegaard. Para o primeiro a religião é apenas um a introdução à filosofia. Para o segundo, não existe nada além da fé, pois essa é a resposta gratuita de Deus ao mal. A linguagem religiosa é a resposta àquela oposição, pois dá resposta à religião, pois essa não pode ser transcendida [...] porque ela é ao mesmo tempo, a agonia da representação e a representação da agonia, no limiar do saber absoluto enquanto essa estiver unida pela agonia da representação e a representação da agonia. A linguagem religiosa simbólica mostra algo que a representação não esgota, mas que vem dada na representação, que estimula a pensar sobre algo. 
Em História e Verdade, Ricoeur diz que na exegese teológica é utilizado ou deve ser utilizado o método hermenêutico aplicado a tríplice formulação, acima dita, a três diferentes âmbitos da experiência humana: o progresso, a sociedade e a epopeia humana. $\mathrm{O}$ primeiro considera os aspectos estruturais, técnicos e manipuláveis que tendem a fazer o sistema; o segundo mostra a ambiguidade ligada ao evento e à consciência e a terceira anuncia o mistério que propõe um sentido, que não seja constituído pelo homem e fechado em um saber absoluto, isto é, um sentido narrado em que o evento mais significante encontra o seu sentido.

Pode-se dizer que esse mistério é o objeto da esperança pelo qual o homem elucida seus sinais e os considera sinais de algo maior, algo que atravessa a experiência humana e transforma-a. Ricoeur diz que "o sentido cristão da história é então essa esperança de que a história profana também faça parte desse sentido que a história sagrada desenvolve, que não existe finalmente senão uma história, que por fim toda história é sagrada" (RICOEUR, 1968, p. 98).

Cada realização humana mostra algo da esperança - graças a, porém os limites dessa realização indicam que se deve transcendê-la - com mais forte razão - e que o sentido último não se dá - a despeito de.

A redenção mostra uma dimensão da superabundância que rompe a ideologia na qual o homem se fecha, por causa da sua racionalidade, que abre ao sentido do evento singular, insignificante, que impulsiona à utopia, à imaginação das possibilidades humanas, que diante de Deus, são sempre incompletas. Toda epopeia humana, para Ricoeur, é imagem de Deus, pois se transcende e reconhece os sinais da presença de Deus na sua história.

No início de todo trabalho hermenêutico existe algo que escapa à hermenêutica e que é testemunhado pelos símbolos. Esse algo é o Kerygma, o anúncio que vem ao homem. Esse anúncio é objeto do testemunho que tem suas características e que constituem o fundamento e a correspondência entre a fé (a afirmação originária que renuncia a ser a fonte de sentido, mas o aceita) e a interpelação originária, pela qual o testemunho se volta a uma nova dimensão 
da existência. Assim, Anúncio e Fé são dois atos que se correspondem "na infalibilidade e no transcender formal". Esses, por sua vez, refletem a correspondência entre Deus e a afirmação originária que atesta o nosso esforço de existir.

Dada a inefabilidade desses atos, como a sua necessidade de representação e representatividade, advém que exista uma linguagem que representa defendendo as suas características de não totalidade e que seja adequada à representabilidade, uma linguagem que implica nela mesmos um transcender, uma estrutura de sentido, enquanto representa, ou seja, dá a pensar.

Esse pensamento que se desenvolve sob o símbolo é ligado à cultura e ao processo de objetivação e, consequentemente, é sujeito ao conflito das interpretações. Esse conflito mostra a ilusão do homem que busca um saber absoluto metafísico e objetivo.

O pensamento que retorna ao símbolo para compreendê-lo é aquele do ato de demitologização. Deve-se retornar ao símbolo através do processo de demitologização e não através do processo de demitização. Ou seja, é preciso que o mito torne-se símbolo (reinterpretar o mito a pena em uma nova economia de pensamento, na qual a pena não seja um momento, uma lógica absurda da sobre abundância da graça, ou seja, perca o falso saber que vem com a interpretação jurídica no demitizar. Mas é preciso que esse símbolo seja recuperado como verdadeiro mito, que pode ser interpretado dentro de uma reflexão filosófica.

precisamente porque vivemos após a separação do mito e da história, a desmitização da nossa história pode transformar-se no reverso de uma compreensão do mito como mito, e da conquista, pela primeira vez na história da cultura, da dimensão mítica. É por isso que, em mo- mento algum, se fala aqui de desmitização, mas, em rigor, de desmitologização, ficando claro que aquilo que se perdeu foi o pseudo-saber, o falso logos do mito, tal como se exprime, por exemplo, na função etiológica do mito. Mas perder o mito como logos imediato é reencontrá-lo como mythos. No entanto, o mythos só poderá provocar uma nova peripécia do logos mediante uma passagem pela exegese e pela compreensão filosófica (RICOEUR, 2006, p. 257). 


\section{Entre a Filosofia e a teologia: A esperança como afirmação originária dentro da Linguagem Poética e do Testemunho}

A filosofia não é teologia, não tem função de teologia, da fidelidade através do testemunho, pois o ideal de fidelidade é orientado pelo saber racional. A filosofia orienta os vários resultados hermenêuticos ao redor do desejo de ser do homem, sem, porém, colocar em parênteses os pressupostos não filosóficos dos quais se parte, mas aceitando-os e verificando-os.

Diante da religião, a filosofia pensa nos limites da simples razão e coloca todo trabalho hermenêutico integralmente sob o crivo da razão. Se, porém, para Ricoeur, existe "apenas um logos, o logos de Cristo, apenas me pede, enquanto filósofo, uma mais completa e mais perfeita realização da razão; nada mais do que a razão, mas a razão inteira” (RICOEUR, 1999, p. 393). Ao teólogo compete interpretar a palavra dentro de uma cristologia, enquanto que ao filósofo, enquanto estudioso da religião, deve-se referir-se ao testemunho dado dentro da cristologia, como um desejo de ser do homem. Pois para o filosofo, Cristo "é mais que uma realidade a testemunhar, é [ele] esquema de esperança [ele] resulta duma imaginação mítico-poética concernente ao cumprimento do desejo de ser" (RICOEUR, 2006, p. 257).

Desta maneira, cabe ao filósofo se colocar em uma relação próxima ao discurso kerygmático e teológico, escutar esse discurso e elaborar um pensamento autônomo sem aceitar a fé, mas só uma pré-compreensão cultural. Pois, o filósofo, mesmo que cristão, tem uma tarefa distinta da do teólogo, não fazendo teologia, mas fazendo uma "abordagem" de aproximação ao discurso.

Ricoeur aplica tudo isso ao problema da liberdade, como pode pensar o filósofo diante do kerygma da liberdade cristã. Ricoeur, então, individua o núcleo propriamente kerygmático da liberdade, algo como o que fez com o da ética, o mal. Individua, assim, o núcleo no anúncio escatológico e na Revelação de Deus como promessa em oposição com os deuses das religiões epifânicas.

É na Revelação, assim, que se gera uma história, essa história leva a um cumprimento sempre esperado, contudo, "não-ainda”. É uma história na qual o cumprimento não pode ser ratificado pela esperança. A ressurreição do Jesus 
(personagem histórico) é o sinal que a promessa é para todos e que seu sentido está na sua vinda, na morte, na esperança.

Assim Ricoeur passa a fazer uma leitura da liberdade sob o prisma da esperança cristã de um ponto de vista puramente filosófico. Ele também considera o ponto de vista psicológico, como imaginação criadora do possível que vence o primado da necessidade. Esse é um procedimento que Ricoeur faz em Culpabilidade, ética e Religião, no qual desenvolve uma análise da culpabilidade partindo do ponto de vista semântico e, encontrando, assim a linguagem simbólica que é doadora de sentido: De um ponto de vista ético, o filósofo francês, tenta através da análise da linguagem religiosa superar o legalismo da lei que acusa a cada um, uma ética não-contingente. De um ponto de vista político-social, tenta superar o fechamento sobre decisão para que se tenha uma abertura à comunidade.

Ricoeur acaba descobrindo que essa leitura filosófica da liberdade não é suficiente, pois, sendo o centro kerygmático da liberdade o pertencimento existencial da ordem da ressureição, logo ele acomoda que cada esperança é esperança "a despeito" da morte. Esse "a despeito de" conserva todo seu trágico e realidade, porém é negado pela esperança, de modo que, a vitória sobre a morte seja selada como próprio sinal de seu contrário. A esperança, assim, pertence a uma lógica da superabundância que supera cada possibilidade pensada pelo homem.

Assim Ricoeur diz que J. Moltmann opõe a promessa ao logos grego, pois,

a esperança começa como uma "a-lógica". Ela irrompe numa ordem fechada; ela abre uma carreira de existência e de história. Paixão pelo possível, envio e êxodo, desmentido ao real da morte, resposta da sobre abundância do sentido à abundância do não-sentido, outros tantos signos de uma nova criação, cuja novidade nos toma, no sentido próprio, inesperadamente. A esperança, no seu jorrar, é “aporética”, não por falta, mas por excesso de sentido. A ressureição surpreende, como sendo excessiva em relação à realidade. Abandonada por Deus (RICOEUR, 1999, p. 400).

Para Moltmann (1970), que influencia Ricoeur, a linguagem da escatologia não é o logos mas a promessa. Não basta acreditar em Deus, mas 
acreditar na sua promessa . O logos é algo fechado, enquanto a promessa é algo aberta à esperança. A linguagem da promessa é utilizada dentro da escatologia cristã como uma chave para libertar a verdade cristã.

A esperança para Ricoeur, enquanto paixão pelo possível é a vocação da liberdade. É “o sentido da existência à luz do [evento] da Ressureição” (RICOEUR, 1999, p. 295). Pensar a liberdade segundo a esperança nos limites da simples razão significa, dizer que a religião me permite abordar uma questão mais ampla do que me é permitido esperar. Essa questão kantiana emerge o ponto de encontro entre a filosofia e a religião, a esperança que toca a capacidade de regenerar a vontade moral, na qual suas estruturas se encontram na filosofia prática. Pensar a esperança na filosofia a partir de temas fronteiriços é desfazer os sistemas fechados e reorganizar o sentido. Ou seja, a inteligibilidade da esperança no leva a modifica a estrutura do pensamento e do discurso filosófico. É acolher o desafio da racionalidade limitada e da limitação da ação humana.

A filosofia tem por tarefa acolher essa esperança e a liberdade, distinguindo entre razão e intelecto de maneira kantiana, pois não é nossa

experiência que limita a razão, mas a razão que limita a pretensão da sensibilidade a estender o nosso conhecimento empírico, fenomenal, espaço-temporal, à ordem numenal. Este movimento inteiro - pensamento do incondicionado, ilusão transcendental, crítica dos objetos absolutos - é essencialmente uma inteligência da esperança (RICOEUR, 1999, p. 404).

Isso se confronta diretamente com a filosofia da religião, pois o homem exige os postulados da razão prática enquanto existe a exigência da totalidade, mas não do saber; porque existe o problema do mal de modo que o mesmo poder com que o homem tem a moralidade de fato, torna-se, na realidade um não-poder. Desta forma, a contingência do mal é a expressão de uma natureza necessariamente cativa da liberdade.

O mal nasce no lugar dessa antinomia. Simultaneamente, mal e esperança são mais solidários do que o pensaremos jamais; se o mal do mal nasce na via de totalização, ele apenas aparece numa patologia da esperança. Para 
dizer resumidamente, a verdadeira malícia do homem apenas aparece no Estado e na Igreja, enquanto instituições da reunião, da recapitulação, da totalização (RICOEUR, 1999, p. 412).

Diante disso, o discurso filosófico é concluído e mostra que tudo que o homem possa dizer eventualmente nada mais é que um discurso poético. Este, nos conflitos das interpretações faz com que o kerygma mantenha o transcender que vai além do nome de Deus como referente das expressões-limite, dos conceitos-limite e da experiência-limite.

$\mathrm{O}$ ato de fé é algo radical, chega ao ponto que o homem não pode nem imaginar algo que permita a compreensão da Revelação como algo que toca o homem. A razão e a Revelação não são distantes uma da outra, contudo não pode ser uma teologia racional ou uma filosofia que coloque a pergunte e a teologia dite a resposta.

Para Ricoeur existe um consenso entre razão e Revelação, de experiências-limite em experiências e expressões que cada uma traz. Veja-se que se trata apenas de um consenso e nada mais, pois tudo isso não tem necessidade de referir-se a Deus para ser válido.

O homem quando diz o seu ato de fé percebe que existe algo na experiência humana que faz desse ato não algo mais absurdo, mas adequado a sua vida, ao ponto de abri-la para horizontes inesperados, nisso está a esperança. Uma esperança racional, nascida no interior do conflito, do sofrimento humano e transmitidos através dos símbolos e literatura, como é o caso do símbolo do mal e da literatura bíblica.

Em Le Volontaire et l'Involontaire, Ricoeur quando se refere à poética fala do consenso, ele volta o pensamento à Transcendência, não mais como exigida, mas como esperada "como Jaspers bem compreendeu, uma filosofia da existência subjetiva e da Transcendência se abraçam mutuamente segundo um incessante derribamento" (RICOEUR, 1950, p.448). O homem faz um salto no consenso e, então, se redescobre, se admira e pode fazer o salto em direção ao Todo-Outro.

Deus é a ideia-limite que está acima da liberdade humana. Enquanto ideia-limite apreendida filosoficamente, o homem pode dar conta que a escolha de sua fé é razoável. Porém, Deus não é somente uma ideia-limite para o 
crente, é uma presença que introduz na subjetividade uma dimensão radicalmente nova, a dimensão poética, e, consequentemente, o centro do sentido que vai da consciência à Transcendência.

Isso não significa aceitar a teologia racional, pois com a razão o homem descobre somente o que é contingente. É, portanto, no risco de aceitá-la que ele se descobre inserido no ser, ser como ato e como horizonte. Essa estrutura de um contínuo autotranscender-se garante a presença do divino como um divino que não pode ser objetivado.

Dessa forma, seguindo esse raciocínio, Ricoeur afirma que a unidade da história, unidade do verdadeiro, não pode ser um objeto, mas deve ser esperada, como sentimento, sentimento que é razão, mas não como saber. Essa unidade da história "só é acessível a um sentido regulador, capaz de purificar o ceticismo historizante, um sentimento que é razão, mas não saber: um sentimento que filosofias se acham finalmente na mesma verdade do ser. Ouso denominar esperança esse sentimento" (RICOEUR, 1968,p. 10).

A reflexão filosófica sobre o sentimento se dá dentro de uma antropologia e ao mesmo tempo em um mistério. Essa reflexão se dá sobre a fragilidade do sentimento como uma diferença de si a si para entender o sentimento como uma categoria que vai além de uma poética da vontade, em paralelo com a imaginação. O sentimento é ao mesmo tempo subjetivo e íntimo. Ele possui o poder de trazer o mundo para nós. Isso aponta a uma superação, uma crítica sobre a emoção, do prazer através da felicidade. Uma vida marcada pelo prazer é evidenciada pela má conduta, pois, assim, o ser humano procura uma satisfação estéril, desprovida de um real valor e de estabilidade. Por outro lado, a busca da felicidade é caracterizada pelo seu planejamento, sem leva em conta as pequenas e triviais alegrias.

O sentimento não é um simples estado de ânimo. Ele é uma intenção em relação ao mundo. Existe uma reciprocidade entre, sentir e conhecer. O conhecer provoca uma ruptura entre o objeto e o sujeito, que destaca, desta forma, destaca objeto do sujeito em oposição ao eu. Ele ainda institui a dualidade entre sujeito e objeto. $\mathrm{O}$ sentimento, entretanto, é compreendido como um relacionamento com o mundo, que explica no ser humano as harmonias e desarmonia. Isso amplia a desproporção do conhecer, que ao invés de reunir, separa. O sentimento 
é definido como manifestação de nossas tensões e de nossas pulsões. A desproporção e o conflito que o sentimento revela como constitutivo do homem o aproxima do horizonte que o simples conhecimento teórico e prático não pode oferecer. Isso recupera toda uma patética da miséria que foi superada na reflexão transcendental como é o caso da agonia existencial de Kierkegaard. A análise antropológica que culmina na desproporção do sentimento, mostra a recuperação ante essa miséria. Essa é a dimensão poética do sentimento: permitir o retorno, sem exaurir a esperança, a riqueza da dimensão pré-filosófica da compreensão. Ou seja, isso permite afirmar que "o nascimento da filosofia na não filosofia, na pré-filosofia; o pathos da miséria é a origem não filosófica , a matriz poética, da antropologia filosófica” (RICOEUR, 1960,p.275).

Ao nominar esse sentimento de esperança, Ricoeur se refere aquilo que é proclamado na predicação pela fé cristã e que se pode chamar afirmação originária. $\mathrm{O}$ sentimento manifesta uma relação ontológica ao mundo, mais originaria e profunda do que a atestada pela consciência da coisa. $\mathrm{O}$ sentimento, como interioridade e como intencionalidade, manifesta, um contraste paradoxal com a realidade: algo pré-reflexivo, pré-objetivo.

Já dissemos no primeiro capítulo que a esperança contida nessa predicação cristã se caracteriza por se referir ao eschaton. Esse se realiza na história sem lhe pertencer, contudo, essa esperança do ponto de vista filosófico é um sentimento racional com o qual o homem se percebe e que não pode se afigurar a um saber absoluto.

A filosofia acolhe a esperança cristã como razão reguladora da reflexão, enquanto a teologia abre continuamente a reflexão, de maneira que a fé não caia em religião, nem muito menos, que Deus se transforme em um ídolo.

$\mathrm{Na}$ prática, Ricoeur mostra que a hermenêutica da linguagem poética e do testemunho fornecem uma base suficiente para pensar uma hermenêutica da esperança contida nos textos sagrados e que é tarefa da hermenêutica filosófica, com sua especificidade dá um norte, coordenação e clarificação aos temas que tocam a existência do homem através desses textos sagrados.

Cabe agora tentar refletir sobre o sentido da esperança na existência humana e como se opera uma da esperança escatológica através do consentimento em Ricoeur. 


\section{A esperança no evento da Ressureição}

A Esperança entra, pois, no campo da reflexão, como reflexão da reflexão e pela ideia reguladora de todo do ser bom; mas, diferentemente de um saber absoluto $(H V, 311)$.

A via pela linguagem simbólica ou religiosa mostra que no homem existe uma natureza fundamental boa. Nesse sentido, a esperança é um agente dinamizador que nos move para frente, que nos enche de expectativas retirando de nós o homem velho em vista do homem novo. Uma inteligência que envolve o nosso esforço de ser no mundo. É necessária uma esperança dentro de uma poética que venha sustentar através de uma linguagem essa esperança, essa linguagem é a religiosa que para Ricoeur é mostrar uma esperança por meio dos eventos e anúncios.

O objetivo desse capítulo é notar o sentido da esperança para a existência humana. Sentido esse que passa por um consentimento e desemborca em uma esperança escatológica. Ou seja, em repor minha existência no movimento futuro do evento da ressurreição. Primeiramente será apresentada a esperança e o seu sentido para existência humana, não como um simples conceito, mas como aquilo que tem por função um transpor o horizonte da fé. Para isso, teremos que analisar a questão do consentimento, da esperança e sua abertura à história.

\section{A Esperança e seu sentido para existência humana}

A esperança como possibilidade de uma ontologia reconciliada ante uma ontologia paradoxal é o desafio de uma filosofia da vontade que vai da questão sobre o mal, passa por uma ontologia da liberdade, até a Transcendência.

A Esperança não é um conceito, um simples sentimento, abstração, ou mesmo uma ilusão. Ela tem uma função e um conteúdo inalienável de nos mover a uma reflexão sobre o nosso agir, pois toca diretamente ao desejo do ser do homem. Ou seja, ela é um momento que recapitula o sentido da vida do homem. Essa recapitulação se dá a "partir dos atos e operações nos quais 
adquirimos consciência de nossa limitação superando-a" (RICOEUR, 1968, p. 313). Ela está ligada à liberdade e introduz em nosso mundo uma inovação de sentido e desenvolve uma lógica própria da existência humana. Por isso é necessário acercar-se da vida concreta do homem através dos sinais da esperança.

No artigo $A$ liberdade segundo a Esperança, Ricoeur faz uma releitura da esperança na filosofia, na qual mostra que "uma hermenêutica da liberdade religiosa é uma interpretação da liberdade conforme a interpretação da ressurreição em termos de promessa e de esperança" (RICOEUR, 1999, p. 395-396). O quanto mais e o apesar de, das categorias paulina, que são o avesso e o direito uma da outra. Surgem como o avesso na argumentação como um livre para e um livre $d e$, contraposto ao "apesar de...", que no fundo remete à morte ou, na perspectiva kantiana lida por Ricoeur, ao mal radical, pois "se a ressurreição é ressurreição de entre os mortos, toda a esperança e toda liberdade existem apesar da morte" (RICOEUR, 1999, p. 398).

Mesmo se colocamos uma ligação entre o desejo de liberdade e a esperança, notamos que a esperança vem de outra origem, pois ela não é apodítica, mas hipotética. A esperança somente pode ser esperada e não evidenciada empiricamente. Ela nos introduz em uma inovação de sentido e desenvolve-se dentro de uma lógica própria da existência humana. Essa lógica Ricoeur chama de a liberdade segundo a Esperança (Cf. RICOEUR, 1999, p. 391-414). Para ele essa liberdade é "o sentido da minha existência à luz da ressurreição, isto é, resposta ao movimento a que chamamos o futuro da ressurreição de Cristo" (RICOEUR, 1999, p. 395).

Ricoeur nos diz que a lógica própria da esperança é a lógica do absurdo. O filósofo francês desenvolve o paradoxo paulino da justificação que se desdobra em uma lógica da superabundância pela qual se funda as categorias paulinas do apesar de e do quanto mais. A esperança, assim, considerada a partir da ressurreição dentre os mortos, faz com que a liberdade se afirme apesar da morte, apesar de um mal que a paralisa, apesar de tudo que possa a negar ou conduzir a seu esgotamento. A afirmação da liberdade é da ordem do paradoxo e não da mediação lógica. 
Para Ricoeur, podemos notar que toda a esperança trará a partir de agora o mesmo signo de descontinuidade, entre aquilo que vai para a morte e aquilo que nega a morte. E por isso que ela contradiz a realidade atual. A esperança, enquanto esperança de ressurreição, e a contradição viva disso mesmo donde ela procede e que e colocado sob o signo da cruz e da morte. Segundo uma expressão admirável dos Reformadores: o Reino de Deus está escondido sob o seu contrário, a cruz. Se o laco da cruz e da ressurreição e da ordem do paradoxo e não da meditação logica, a liberdade segundo a esperança já não e só liberdade para o possível, mas, mais fundamentalmente ainda, liberdade para o desmentido da morte, liberdade para decifrar os signos da ressurreição sob a aparência contraria da morte.

A escatologia cristã permite uma abertura ao futuro, pois esperança começa como uma "a-lógica". Ela irrompe numa ordem fechada; ela abre uma carreira de existência e de história. Paixão pelo possível, envio e êxodo, desmentido ao real da morte, resposta da sobreabundanda do sentido a abundancia do não-sentido, outros tantos signos de uma nova criação, cuja novidade nos toma, no sentido próprio, inesperadamente. A esperança, no seu jorrar, e “ aporética”, não por falta, mas por excesso de sentido. A ressurreição surpreende, como sendo excessiva em relação a realidade abandonada de Deus.

Pois entre a esperança e a realidade que leva à morte existe um hiato, uma descontinuidade que faz com que a força da afirmação, não seja uma autoafirmação, um dinamismo imanente que faz o homem perseverar na existência, mas sim uma garantia recebida e um estímulo que provém do anúncio da ressurreição, porque "toda esperança trará a partir de agora o mesmo signo de descontinuidade, entre aquilo que vai para a morte e aquilo que nega a morte" (RICOEUR, 1999, p. 399). Assim, motivado pela Esperança da ressurreição, a liberdade é, então, uma "liberdade para o desmentido da morte, liberdade para decifrar os signos da ressurreição sob a aparência da morte" (RICOEUR, 1999, p. 399).

Pois bem, uma liberdade que desafia a morte é uma liberdade que tem por possível a ressurreição, que é animada pela paixão pelo possível e que de outra maneira se opõe à resignação. Esse é precisamente o ponto que Ricoeur vê uma resposta ao primado da necessidade, pois 
a realidade (...) não é somente o conjunto dos fatos susceptíveis de serem constatados e das leis suscetíveis de serem verificadas. É também em termos psicanalíticos, o mundo das coisas e dos homens, tal como apareceria a um desejo humano que houvesse renunciado ao princípio do prazer, isto é, subordinado seu ponto de vista ao todo (RICOEUR, 1999, p. 437).

A realidade para Ricoeur, dessa forma, não é somente um conjunto de fatos que são observáveis, mas a capacidade de compreensão do mundo cultural humano. Essa compreensão implica na capacidade de reestabelecer o mundo objetivo. O real, assim, não é somente o necessário, mas o amor da criação.

O homem tem uma necessidade inelutável de resignar-se, pois nada pode contra o seu destino. $\mathrm{O}$ que doa à realidade o caráter trágico de Ananké é o projeto humano de resignar-se, de submeter-se ao que considera como inexorável e que o força à uma ascese do desejo. O Ananké ou a realidade convertida em necessidade é então réplica de uma decisão humana que opta em favor de uma interpretação que propõe ao homem, diante da dureza da vida, uma "forma de suportar o fardo da vida" tal como Jó que suporta tudo sem emitir uma só palavra sem Esperança e sem medo como diria Schiller (1997). Apesar das aparências esse entendimento retorna ao presente, o eterno presente parmenidiano e consagra o que ele queria destruir: a visão metafisica do mundo. Essa visão é caracterizada como uma separação do inteligível e do sensível que propõe ao homem de se afastar do que é perecível e se aproximar do que é eterno.

É necessário notar que a metafísica reafirma, ao menos, a visão estoica, a visão de que o sensível é graça a um elemento ético do presente, que consente sem reserva a uma ordem do todo nem com esperança nem com medo, pois “a esperança é rejeitada do mesmo lado que o temor, como uma perturbação, uma agitação" (RICOEUR, 1999, p. 397). Este consentimento, que está na passividade da alma que contempla o todo, é um consentimento imperfeito, pois a subjetividade se enclausura em si mesmo e abre um abismo intransponível entre a alma e os seres naturais encerrando-a dentro de si mesmo e nos seus próprios limites. 
Ricoeur mostra que diferente da visão estoica da liberdade há uma interpretação órfica da existência, em um consentimento hiperbólico. A visão estoica pretende arrefecer qualquer princípio de subjetividade e de ipseidade no cerne da indiferença da natureza. Essa visão não quer compreender a corporeidade como uma "vida em mim sem mim", mas quer exilar a esfera das paixões e do involuntário para longe de minha interioridade, de maneira a preservar a inalterabilidade do meu estado de alma.

Para Ricoeur(1977, p. 528), Freud será o único que pode equilibrar resignação e necessidade em um amor pela criação como sugere as últimas linhas do Leonardo e que evocam uma natureza plena de infinitas razões que nunca esteve na experiência. Esse excesso de razões continua na natureza em relação às razões exprimidas na experiência, abre o caminho para a paixão pelo possível.

Contudo, uma liberdade sustentada pela esperança é capaz de ir e ver além da experiência atual e de se fazer aliada de uma imaginação que evoca, atende e dispõe o incessante vir-a-ser do ser-aí sobre as aparências do contrário. Pois,

a esperança é o avanço do possível sobre o necessário; é a afirmação de que, aconteça o que acontecer, o homem pode ser, porque lhe é dado ser possível (RICOEUR, 1971, p. 69).

O ser possível é a garantia que anima a liberdade segundo a esperança que procede da categoria do quanto mais, acreditando que pertence ao reino da libertação. Assim, a lógica absurda não contradiz o élan vital, nem é surda à economia da superabundância. O que é absurdo dentro da lógica da esperança, é uma incompreensível reversão que é operada pela justificação do ímpio contra a lógica de identidade que caracteriza a lei da pena e a qual, segundo Ricoeur, Paulo coloca em uma formulação vigorosa “o salário do pecado é a morte” (Rm. 6,23).

$\mathrm{Na}$ lógica da esperança, em um instante, a situação se reverte e saltamos da morte para vida, eis o que é ininteligível dentro da lógica da esperança. Essa passagem brusca que atropela a lida retribuição, destroça a economia da lei e o quadro jurídico da justificação. Assim, a lógica da pena é invertida, pois a equivalência que ela postula entre o delito e a sansão é arruinada pela nova dis- 
posição da graça, conforme Ricoeur mesmo diz: "A lógica da pena serve, assim, de contraste, de contrapartida, de contraponto para o anúncio e a proclamação que é o próprio Evangelho (...) a lógica absurda ultrapassa naquilo que se pode chamar a lógica da 'sobre abundância”' (RICOEUR, 1999, p. 366).

$\mathrm{O}$ anúncio do Evangelho desenvolve em sua linguagem uma lógica da superabundância que exprime uma outra economia, a da graça. Ela rompe com a economia da lei e com sua lógica de equivalência. Ela constitui a alma do desmedido que o homem porta contra a morte sobre todas as formas. A morte continua sua obra de destruição, a liberdade do crente porta a consciência da economia da graça e desvenda os sinais da “... aspiração da criação inteira para a redenção” (RICOEUR, 1999, p. 399) na qual a liberdade se sente, se sabe e se quer. Entretanto, na loucura da cruz, a lógica do excesso é inverificável. Ela se realiza progressivamente como intepretação da ressurreição, no evento crístico, através das contradições da existência humana, individual e coletiva. Desta maneira, do ponto de vista da esperança, "ser livre, é sentir-se e saber-se pertencer a esta economia, estar à vontade’ nessa economia” (RICOEUR, 1999, p. 399).

Do mesmo modo, o problema do mal, que a consciência ética associa à liberdade, recebe um novo esclarecimento que se localiza dentro da economia da superabundância. Considerando o cenário da esperança, a falta é colocada diante de Deus. De todas as formas, a consciência que esse pecado produz é o rebelar-se contra Deus, que não deve ser interpretado como um agravo da consciência do mal. Ele é uma perspectiva que remete o mal ao movimento da promessa e ao mesmo tempo que descobre o horizonte da restauração. Com efeito, "é preciso, pois que a ressurreição desenvolva a sua lógica própria que anula os esforços da lógica da repetição" (RICOEUR, 1999, p. 401). Esta reivindicação do domínio do si pode se exprimir pela vontade de injustiça mais do que pela própria justiça. Uma consciência que confessa é uma consciência que se arrepende e que vê a possibilidade de restauração de sua ligação com Deus. A consciência confessora se situa, desta maneira, diante da promessa da regeneração, ou melhor, a remissão de seu mal.

Para Ricoeur, a vontade é fundamentalmente constituía pelo desejo de realização ou de cumprimento da lei. O mal concerne ao uma visão de tota- 
lização na qual "é preciso, pois, ter a coragem de incorporar o mal na epopeia da esperança; de uma maneira que nós não sabemos, o próprio mal coopera de encontro ao Reino de Deus” (RICOEUR, 1999, p. 399). Deste modo, o mal constitui o que Ricoeur chama de "a patologia da esperança" (RICOEUR, 1999, p. 399), uma perversão inerente a problemática do cumprimento e da totalização. Desta forma, é possível pensar a epopeia do mal como uma totalidade chamada desejo. $\mathrm{O}$ mal, desta forma, é a doença da esperança, a "doença para morte" como diria Kierkegaard. Essa doença consiste na vontade de operar uma síntese passional, ou seja, o finito sem infinitude, ou mesmo, no infinito sem finitude. $\mathrm{O}$ mal é a desesperança que impulsiona um valor a ter por ele mesmo a síntese da virtude e da bondade.

O mal se inscreve, consequentemente, no horizonte aberto pela esperança, pois, para Ricoeur "o discurso propriamente religioso sobre o mal, [...] é o discurso da esperança” (RICOEUR, 1999, p. 426), formado pela visão de totalidade que aguarda o cumprimento total da vontade humana. Da mesma maneira que o mal prolifera, a graça superabunda, de forma que o mal é de certa maneira incorporado a epopeia da Esperança e faz com que avance o Reino de Deus. Partindo da redenção e do ponto de vista do Reino que se avizinha, o mal toma um valor educativo para com a Esperança, pois "pensar a liberdade segundo a Esperança é repor minha existência no movimento, a que se pode chamar como Jürgen Moltmann, o futuro da ressurreição em Cristo” (RICOEUR, 1999, p. 426). Ao revelar o fracasso do homem em realizar o cumprimento da lei, o convida a desejar a salvação. O etiam pecata e o felix culpa exprime uma lógica absurda fundada igualmente sobre o sentimento pertencimento à ordem da graça, que designa a esperança na ressurreição, ou seja, em um poder de transformar o não sentido em sentido. $O$ olhar da fé se orienta para o fim do mal, em direção ao acontecimento em que o mal contribui sem saber para a Esperança. A partir da redenção, o mal como lei, adquire um valor pedagógico, que educa o homem, mostrando a falsa pretensão da própria justiça em vista de esperar na promessa de recapitulação final de todas as coisas.

A patologia da esperança acompanha a esperança normal, que consiste na realização do desejo de ser e da regeneração do poder da liberdade. Ela é 
proclamada nas figuras do anúncio, em particular na figura do Cristo que esquematiza nos textos a realização plena da liberdade como foi dito no primeiro e no segundo capítulos. Essas figuras se reportam ao desejo do homem de que a Esperança tenha um impacto real sobre a existência humana. Pois, "como é que uma vontade é afetada, no seu desejo mais íntimo", pela representação desse modelo, desse arquétipo de humanidade agradável a Deus, a que o crente chama Filho de Deus? Deixemos essa pergunta em suspenso no momento, para mais a frente abordá-la com maior precisão em uma relação entre conteúdo representativo da esperança e o desejo de realização.

\section{A esperança de Gabriel Marcel em na esperança de Ricoeur}

A experiência de transcendência que o existencialismo de Marcel propõe como aproximação concreta do ser humano com a transcendência. Essa experiência de transcendência dá a experiência humana a oportunidade de converter o seu peso ontológico, anteriormente perdido nos limites do pensamento lógico.

É estreita a relação entre o sentimento existencial e a esperança que surge no caminho do "homem itinerante". A experiência de Transcendência que o existencialismo de Gabriel Marcel, pelo qual Ricoeur é influenciado, propõe uma aproximação do ser humano com a Transcendência, pois a experiência da Transcendência dada pela experiência humana, na verdade tem um peso ontológico, que beira os limites do pensamento lógico, conforme nos fala Gabriel Marcel em Homo Viator (2005), Ricoeur, bebe da filosofia de Marcel, no qual existem três experiências de transcendência:

A primeira é a da fidelidade, que é diferente da obediência que resguarda só o fazer, a fidelidade é um dom que um ser adulto toma para si e dá credito e ama.

A segunda experiência é a da esperança, essa deve ser vista como algo que descentra o sujeito. É um amor por nós que permite encontrar a forma legitima da esperança em mim. Essa esperança em mim deve passar necessariamente através do nós, no qual o eu, como outro, está incluso.

A terceira experiência da transcendência é a abertura ao amor, que consente em superar a opacidade do ter no qual se fecha o homem sobre si mesmo. 
Essa perspectiva do amor permite uma libertação, que vai do ter ao ser, em que a liberdade não é mais desafiada, exilada, mas sustentada por uma "humildade ontológica”. O método de G. Marcel pode ser definido como fenomenológico.

A fenomenologia é definida por Ricoeur como aquilo que não se atem aos conteúdos psicológicos enquanto experimentados, mas que se aproxima da experiência, sem o desejo de explicá-la, ou seja, de reduzi-la a elementos simples. Pois, respeitar o fenômeno, em sua realidade integral, tal como se oferece, é compreender o que a fenomenologia significa em sua intenção mais significante e não explicá-la através de componentes insignificantes. Ou seja, Ricoeur nos diz que o método de Marcel consiste em suscitar, na ocasião da descrição, uma economia da liberdade e uma invocação transcendente. Estes são os fatores hiper fenomenológicos e propriamente metafísico. A cada instante, vai-se lembrando o proposito transcendente da análise. De forma que, a função da filosofia é o ser e não a existência, pois transcender é o movimento que, próximo ao ser, recusa os modos do ser que não são ser em si. Isso deve ser a primeira e mais detalhada elucidação da condição humana.

Essa fenomenologia que Ricoeur descreve é muito próxima ao que Jarpers chama de iluminação da existência, em que a minha existência consiste na própria ação de existir através das situações limites que a consciência existencial toma de si.

O método de Gabriel, por fim, pode se definir como dialético, não tanto pelo sentido abstrato de tal expressão, de um esforço de superação que se apoia nas ideias ou categorias, quanto no sentido concreto de uma dialética capaz de evidenciar a implicação que nasce através da linguagem comum, pelo qual o trágico se refere ao pessoal e esse ao transcendente. Esse é o significado da dialética que opera a superação do simples fato.

Essa abertura, de acordo com Ricoeur, ao transcendente da existência, se dá tanto em Marcel Como em Jarpers, pois ela é a contrapartida positiva da comum desconfiança na construção puramente racional, ou seja, em Marcel a crítica ao saber científico é diferente da que existe em Jarpers, pois sua proposta não é de uma crítica, mas de uma espiritualidade. A crítica do saber científico em Marcel se dá, somente, pelo motivo, por querer recuperar o mistério da existência que a objetividade reduz ao problemático, pois a objetividade surge 
como o reino pelo qual o problemático serve de antítese ao mistério. Por esse ângulo, a verdadeira certeza não está no pensamento, nem mesmo no pensamento objetivo, pois o primeiro indubitável não é o pensamento que reflete sobre a dúvida, mas a presença que é anterior à dúvida, que a torna possível. Pode-se dizer que, a crítica do saber objetivo, problemático, encontra uma importante sustentação na refutação de Marcel quando se confronta com um sistema de saber, pois, isso, equivale ao triunfo da imanência.

Para evitar uma errada compreensão do pensamento de Gabriel Marcel, deve ser dito, que a fé não é equivalente à intuição. Para Ricoeur, em Marcel, a tarefa da filosofia é de superar a reflexão primária, que acolhe em um sujeito impessoal às condições de validade do conhecimento objetivo e desatrela o pensamento da sua condição carnal. A reflexão se torna de segundo grau, assim, evidenciando como uma pureza do sujeito despersonalizado não é um triunfo. A segunda reflexão é inevitavelmente dialética. Ela é negativa, pois se afirma que o ser não é o objetivo. A negação da objetividade é a negação de uma perda, pois essa negação da negação se traduz ao nível racional como uma plenitude de presença.

Esse método se caracteriza como uma segunda revolução copernicana, que consiste no descentramento do sujeito, mostrando, assim, como ele é englobado na questão ontológica.

A liberdade para o homem parece inacessível, pois ela coincide com o mistério central do nosso ser que nos escapa. A filosofia deve sempre refletir sobre a liberdade, mas não dever recusar que a enunciação paradoxal, a nível verbal, não pode ser expressão de uma união que é mistério. Nessa perspectiva a liberdade de recusar o absurdo, reduz-se à interrupção arbitrária de uma cadeia de reflexão, no qual me persuado que o absurdo não é absurdo.

Ao superar a tentação de ver a liberdade como um poder contrário, essa aparece como resposta e disponibilidade. A sua verdade consiste em superar o poder de recusa e dos contrários, passando do dilema ao consentimento, com a filosofia que vai da recusa à invocação. Logo, a liberdade é um ponto de partida e uma conquista, mais que algo que se adquire e que se possui. 
Em seu limite, a liberdade aparece com o consentimento, consenso, perfeito. $\mathrm{O}$ paradoxo da liberdade e da graça não é mais que na palavra. Não aparece aqui a crítica ao ateísmo que se firma em uma liberdade de si mesma. Vejamos a questão do consentimento.

\section{$3.1 \mathrm{O}$ consentimento}

A análise da vontade em Ricoeur é uma apreciação da ação humana. É mediante o acento sobre a fenomenologia da vontade, ou seja, uma descrição pura dos atos da vontade, que se operar a suspensão da experiência entre falta, que é resultado de uma má vontade e entre a transcendência. A suspensão momentânea do caráter empírico da vontade impede, em um primeiro momento, de contrapor o movimento da existência que responde à vontade. Essa suspensão permite descrever três manifestações fenomenológica do querer, que são: Decidir, que é um ato da vontade que se apoia em razões que correspondem a irrealidade do projeto; ao mover, que é o ato da vontade que desestabiliza o poder, o que corresponde a efetividade da ação; o consentir, que é um ato que assente à necessidade.

Cada um desses correspondem a um polo do involuntário no qual: a decisão encontra seu fundamento uma motivação, uma razão de agir, que pode ser consciente ou não, mas que está ancorada em necessidades reais que são irredutíveis à vontade; o movimento do corpo que corresponde aos hábitos, em que a vontade encontra por vezes seus limites na necessidade física; e o consentimento que deve ser pensado em relação a um não valor absoluto, no qual as manifestações são aqueles caracteres do inconsciente e da vida, ou seja, em um primeiro plano, o ato voluntário de consentir consiste no reconhecimento do que não posso projetar, pois o objeto do consentimento extravasa todo e qualquer projeto. Em um segundo plano, o consentimento realiza a conciliação entre liberdade e natureza, entre voluntário e involuntário, consciência e corporeidade.

No ato do consentimento há um caráter misto de ação e de conhecimento intelectual. O consentimento é, primeiramente, uma representação teórica da necessidade. Entretanto, esse conhecimento da necessidade, essencial à 
liberdade, não é verdadeiramente teórico, como uma contemplação à distância do corpo, mas uma aceitação ativa da necessidade.

Por essa aceitação, o consentimento é uma espécie de ação que busca juntar a necessidade à liberdade que a aceita. De uma maneira prática, o consentimento tem uma relação analógica com os dois outros momentos da vontade. $\mathrm{O}$ consentimento é um imperativo. Entretanto, esse imperativo, se torna inevitável, não levando a necessidade em si, mas por mim. Ao aceitar a necessidade, o consentimento não antecipa nada, ele não forma um projeto que abre para uma possibilidade realizável na ordem do mundo e em um futuro. Ele apenas concorda, aceita, o presente.

Desta forma, a mesma vontade que se projeta no futuro e o decide, isto é, o talha, aceita uma situação que porta a marca da interioridade e que convida a considerar as causas que empurram para trás e não os fins que o chamam para frente. Não posso querer o novo sem encontrar o antigo e encontrar-me já lá. A necessidade é uma situação realizada na qual me encontro implicado (RICOEUR, 1950, p. 322-323).

A essa aceitação da necessidade pela liberdade, o consentimento se aproxima do esforço (movimento). Na prática, o consentimento é a condição da ação transformadora, pois "não mudo nada no texto das coisas quando não adoto o contexto implacável da necessidade" (RICOEUR, 1950, p. 323). Por outro lado, o esforço e o consentimento, são duas modalidades pelas quais o homem enfrenta o real para buscar sua expressão e sua realização. Contudo, o consentimento difere do esforço nesse momento, pois é um querer sem poder. Ele é simplesmente uma atitude que converte sua impotência em uma fonte de atividade nova, na qual "transformo toda necessidade na minha liberdade, então o que me limita e, por vezes, me quebra, torna-se o princípio de uma eficácia toda nova, de uma eficácia inteiramente desarmada e desnuda" (RICOEUR, 1950, p. 333).

Ao adotar a necessidade, o consentimento se comporta como uma espécie de posse, de possessão, de maneira que a relação de posse é uma relação que não altera a natureza das coisas, mas as inclui completamente na esfera huma- 
na do pertencimento. Eu, portanto, possuo a posse de mim mesmo e torno-me meu. No entanto, o que me pertence, esse eu, se situa dentro da zona mediana entre o em mim e o fora de mim. Em sua referência a mim, o meu conserva suficiência, ele tende a tornar-se eu sem se reduzir jamais a mim. Essa identidade tendência à manutenção entre a diferença entre mim e o meu. Igualmente, a necessidade aceita tornar-se a liberdade sem nunca se identificar com ela.

Ao contrário da possessão, o consentimento não pode jamais se transformar em consumação da necessidade. Nele, não é suscitada relações de concorrências, de usurpação, de desapropriação, de inveja e de uso com um objeto, pois "A necessidade está sempre comigo, e cada um tem a totalidade da vida e da morte. Faço-a minha de uma maneira inimitável que é propriamente consentir. Ela seria mais paciência que posse. A paciência suporta ativamente aquilo a que se submete; ela age interiormente segundo a necessidade que ela sofre" (RICOEUR, 1950, p. 324).

O Consentimento, portanto, é o ato de uma liberdade desarmada e desnuda que, diante da impossibilidade de transformar a necessidade implacável, usa de paciência. Ora, essa incapacidade não atinge somente a faculdade prática do Cogito, ela atinge também o poder de conhecer. O corpo compromete o Cogito na aventura de descentramento, igualmente do ponto de vista do conhecimento. A existência corporal conduz a uma reflexão nas profundezas da afetividade, onde se torna manifesta que o eu sou ultrapassa o eu penso.

Certamente, o sentido compete a circunscrição do Cogito. Entretanto, experimentar é sempre mais que compreender. Se é então verdade que a filosofia deve iluminar os termos da existência, é também verdade que essa existência ultrapassa a razão e que, por isso, é impossível penetrar totalmente a afetividade.

O conhecimento da afetividade necessária é a passagem para o pensamento objetivo que estuda a necessidade e em geral o involuntário corporal. Nesse ponto, deve-se tomar cuidado para não naturalizar o corpo nem impedir que o corpo seja melhor conhecido pelas ciências objetivas. Se o caminho pelas ciências se efetua segundo a relação de diagnóstico que tende a recuperar em proveito do conhecimento subjetivo do corpo o índice de subjetividade ignorado pelo conhecimento objetivo de seu próprio corpo, a relação de diagnóstico 
inicia, desta forma, a segunda revolução copernicana que descentra o Cogito relacionando-o a suas condições de enraizamento e de existência.

\subsubsection{Consentimento e Esperança}

Pode-se dizer que em Ricoeur existem dois pontos que justificam uma conexão entre consentimento e esperança: encarnação e o mal.

$\mathrm{O}$ consentimento exclui uma recusa, nesse caso uma recusa ao mal. Essas duas atitudes formam uma alternativa de uma opção existencial que implica no reconhecimento dos limites humanos e, consequentemente, da Transcendência. Aqui se revela os limites corporais como Ato limitante. Esse é o lugar no qual a razão através da recusa à Transcendência não se dá jamais de forma explicitamente declarada sobre a negação da Transcendência. A recusa se disfarça sobre a forma de uma "afirmação altiva da consciência como absoluto, ou seja, como criadora ou como produtora de si” (RICOEUR, 1950, p.436). A recusa da Transcendência se esconde na desmedida do homem. $\mathrm{O}$ ato que a funda e a dissimula é um decreto para o qual o homem reivindica para ele uma liberdade absoluta em recusar a contingência de sua existência e em um sonho de uma gênese ideal de si.

Ricoeur se esforça em desmascarar a vã pretensão da liberdade de agigantar-se, não só como uma concepção da liberdade sobre uma recusa camuflada em uma aceitação de uma autoposição, mas mais ainda que não corresponde a descrição dos fatos da experiência humana da vontade. Ao ser conduzida pelo princípio da reciprocidade entre voluntário e involuntário, a análise eidética da vontade desmente o idealismo transcendental que subjaz ao desejo de uma liberdade toda poderosa. Da dialética do Cogito e do corpo resulta a conclusão de que querer não é criar, pois “a liberdade não é um ato puro, ele é em cada um de seus momentos atividade e receptividade, ela se faz acolhendo o que não faz: valores, poderes e a natureza pura" (RICOEUR, 1950, p. 536).

Entendendo, portanto, que a liberdade depende do corpo que a nutre e porta sua iniciativa, ela toma consciência de seu status humano e descobre que ela é uma liberdade motivada, incarnada e contingente. A raiz corporal da 
liberdade é, assim, a razão de uma motivação parcial da decisão, da realização temporal e mundana da existência e, desta forma, de característica singular e factual de cada liberdade. Para o homem, a liberdade é reciprocidade de um involuntário absoluto do corpo no qual se apresenta como "a figura doente da Transcendência” (RICOEUR, 1950, p. 536).

Se a demonstração das estruturas ontológicas do querer, tais como a análise estrutural as põe à luz, revela o absurdo da recusa e a vanidade da ilusão autoposicional que ela não tem o poder de abolir, pois a recusa não revela a estrutura, mas a opção ética. Então, a negação de nossa condição concreta é uma possibilidade existencial. Ela depende da posição que o homem adota em face à experiência da contradição de nossa existência, a realidade que nos funda anuncia como Ato que torna contraditório a existência e, através dessa contradição, a coloca em movimento direção a ele.

Entretanto, nem a recusa, nem o consentimento tem o poder de criar ou de suprimir; eles constituem somente uma tomada de posição em relação ao Absoluto que desencadeia o movimento escape de nossa existência. A recusa ou o consentimento implica no reconhecimento da realidade absoluta que nos coloca definitivamente diante do aceitar ou recusar a viver uma existência que não nos pertence. Essa aposta cria uma situação ética e coloca uma das opções mais fundamental da filosofia e da vida: ou Deus ou eu.

Se a recusa remete a uma opção por um eu que se autofunda, ela se apoia sobre o caractere de nossa condição incarnada que a toma como circunstância. O corpo pode, com efeito, sustentar ou quebrar, ou mesmo destruir o élan criador da existência. De um lado, ele pode servir de trampolim para uma existência que se eleva; de outro dificultar o seu voo. Se, entretanto, a encarnação se orienta em direção de um acolhimento da força criadora, ela se submete, por vezes, à provação do poder desestruturante.

A vida nos conduz e nos leva ao mesmo tempo. Essa ambiguidade se reflete no Ato limitante que tem traços da criação e da destruição. Mesmo se ela sabe que a ela pertence, a consciência não tem nenhum meio de determinar a natureza de seu fundamento a partir do que ela sente em razão da ambiguidade que ela vive. 
A atitude lógica consiste, então, em suspender o julgamento e a abster-se de uma escolha enquanto persistir a dúvida sobre a essência do fundamento. A opção ética depende do conhecimento metafísico do Ser. Da mesma forma, o conhecimento do ser não desprende da consciência que, por essência, livra-se a si mesma em direção ao ser que a funda. Por outro lado, contaminada pela ambiguidade da vida concreta, o conhecimento do ser, não é unívoco enquanto o ser manifesta sua essência.

Desta forma que a metafisica que subtende a opção ética é uma metafísica da manifestação do ser. Embora seja uma atitude razoável, o consentimento guarda uma caraterística problemática enquanto que o homem não obtém alguma clareza referente a bondade do Ser. É somente na medida em que o fundamento revela sua bondade criadora que o homem consente à ele sem reserva na admiração do mundo tal como ele é e em um acolhimento de um eu que renuncia a si e coloca-se para acolher o Ser sobre o qual repousa. $\mathrm{O}$ consentimento postula, portanto, uma manifestação do Ser que atesta sua bondade e a do mundo, dissipando, assim a ambiguidade em torno de sua natureza a partir da manifestação da encarnação.

O tema da encarnação, influencia Ricoeur a pensar sobre a esperança, pois está no centro da reflexão marceliana. Nele o corpo é considerado o mais importante sinal da existência, pois, reconhece o corpo como ponto de referência de todos os existentes e a encarnação como ponto central da reflexão filosófica, é reconhecer o privilegio da minha existência corporal. $O$ corpo é a superação da oposição entre interioridade e exterioridade. É a meta que se traça que depende de mim e que não depende de mim, entre o ato puro e o evento puro. Ele é a mediação absoluta com o universo e não é redutível a um puro instrumento.

Ao tema corpo de Marcel, junta-se ao do tempo. Ele pretende superar a visão kantiana na qual o tempo é uma simples forma de conhecimento. $\mathrm{O}$ tempo marceliano é o revelador da nossa condição humana. O tempo para Marcel é assinalado pela desgraça essencial. Esse não mais apreendido na sua totalidade, mas gota a gota, vamos colhendo o sentido global da vida. Pois, no coração do tempo resta apenas a desilusão de não ser a eternidade, a qual não 
resta nem mesmo a mais pura intenção. A duração temporal me revela que a encarnação é o tempo da prova e da traição à Deus pelo pecado.

A reflexão sobre o corpo e, a duração do tempo da provação e da possível traição, conduz Marcel ao tema do desespero e da morte, a possibilidade do desespero é somente uma afirmação de inspiração kierkergardiana, como é também em Ricoeur, é organicamente junta ao pensamento que reifica o mundo e o reduz a um objeto. Nesse quadro de objetivação total do mundo da técnica, a morte é desesperante, porque é o fim, de mim, do meu corpo e do tempo. Assim, a reflexão sobre o corpo revela na filosofia uma tensão e uma ambiguidade: o meu corpo me insere na existência, em meio a minha presença no mundo; e de outra parte é o corpo é o lugar do desespero, que pode escapar somente com um ato de transcendência do qual esse é o trampolim.

\subsubsection{O consentimento e o Mal}

Consentir sem reservas a esse mundo tal e qual se apresenta, é impossível, pois "o mal é o escândalo que sempre separa o consentimento da implacável necessidade"(RICOEUR, 1950, p. 456). Seja o mal cometido ou sofrido, ele se constitui uma pedra de tropeço. Assim, convêm ir ao cerne da intenção da meditação Ricoeuriana sobre mal a fim de entender a necessidade de esperar para consentir.

Primeiramente deve-se assinalar que o mal é uma realidade existente no mundo e faz parte de nossa história. Uma filosofia que esteja interessada pela existência concreta do homem e suas questões vitais não pode esquivar-se do problema do mal. Além disso, a questão sobre o mal aguça a interrogação humana a respeito da origem, sentido e fundamento, não só da existência do mal, mas da existência humana. Tomando esse caminho não somos impedidos de envereda-lo na Esperança de uma saída.

O mal em Ricoeur é integrado, em sua reflexão filosófica, a título de realidade histórica. Ele o assume em seu projeto, como vimos no primeiro capítulo, pois quer mostrar que o mal, a despeito de toda a sua negatividade, tem o poder de aniquilar a relação de participação que a análise eidética impede entre homem e seu Fundador. $\mathrm{O}$ mal fornece uma prova, pelo absurdo: é o ato pelo qual o ho- 
mem busca se achegar ao Ser, sem cessar de participar desse processo. A reflexão ricoeuriana sobre o mal mostra como o homem pode concretamente consentir nesse ato de participação ao Ser que constitui sua humanidade essencial.

A reflexão é um trabalho permanente de apropriação promovida pela exegese dos testemunhos involuntários, inconscientes e irrefletidos da nossa atividade criadora. Ela é o esforço de captar o Cogito, não em um processo imediato, mas pela mediação temporal como revelação. $\mathrm{O}$ ser humano somente acende a sua intimidade através da analogia e da mediação, no caso de Ricoeur, ao menos nesse momento de seus escritos, pelos símbolos e pelos textos.

Ela conduzida pela visão moral do mundo, chega a uma visão antinômica, que é a visão trágica do mundo por constatar que o homem culpável é também vítima de uma agressão transcendente. A aposta por um caractere contingente do mal pode buscar a reconciliação das duas concepções do mal. Se a conciliação é possível ou não, é notório que essa antinomia torna difícil o consentimento e faz pairar sobre a existência, a ameaça possível de um deus mal. Por si mesma, a consciência não possui nenhum meio de fechar essa possibilidade. Somente o Ser, manifestando sua bondade tem o poder de o fazer. No caso do mal, Deus revela sua bondade livrando o homem do mal. Isso porque, para Ricoeur os textos que transmitem a fé, em particular, os da fé cristã, tem a capacidade de dissipar a tonalidade trágica do mal da existência humana. $\mathrm{Na}$ verdade, essa fé oferece, de acordo com as suas condições, a remissão dos pecados, ou seja, põe um fim ao mal. A hermenêutica desses textos abandona a exegese e a heurística e dá lugar a uma investigação filosófica.

O envolvimento da Transcendência no ato do consentimento mostra uma representação em que: a admiração somente é possível porque o mundo é uma analogia da Transcendência. A esperança, assim, se torna necessária, pois o mundo é o todo outro da Transcendência. A admiração, canção do dia, se maravilha do visível; a esperança transcende a noite. A admiração diz: o mundo é bom, ele é a pátria possivel de nossa liberdade. Eu posso consentir. A esperança diz: o mundo não é a pátria definitiva da liberdade. Eu consinto o possível, mas espero ser livre do terrível, e no fim dos tempos, usufruir (gozar) de um novo corpo e de uma nova natureza concedida pela liberdade" (RICOEUR, 1950, p. 456). 
$\mathrm{Na}$ verdade, é a esperança que engendra a admiração. Irradiando a bondade do Ser, a Esperança ilumina a maravilha da natureza que obtém seu esplendor sobre a obscuridade da noite. Ela adentra nas trevas para fazer brilhar a luz do Amor.

Se então não podemos interpretar o consentimento como uma capitulação ou como resignação, isso faz crer na bondade do Ser e da Criação. O consentimento é a celebração do Ato criador na noite de nossa história. Contudo, para quem acolhe a ambiguidade da experiência humana, essa bondade não é evidente. Pois se as experiências alegres a sugerem, as experiências más a obscurecem, posto que o dia e a noite se conjugam na vida. A razão, de resto, pela qual Ricoeur propôs entre desafio e a resignação, o consentimento é a atitude humana que define a relação verdadeira do homem com Deus e, através desse, com a necessidade. Mesmo se o consentimento supõe o reconhecimento do Ser, ele é, enquanto sujeito em ato, uma opção ética que condiciona o conhecimento metafísico e religioso da natureza do Ser. É através desse conhecimento que a ambiguidade da encarnação e prova do mal torna-se problemática e consequentemente, confunde a consciência e torna o consentimento suspenso.

\subsection{Esperança e a Escatologia Cristã}

Até o presente momento discutimos como a esperança se dá na experiência humana, como o consentimento se liga com o mal e com a esperança, cabe-nos agora refletimos sobre a escatologia e a esperança no cristianismo.

De fato, Ricoeur, em O Conflito das Interpretações e em História e Verda$d e$, vai em sua perspectiva em direção das Fronteiras da Filosofia, da racionalidade humana. Nesses textos, podemos dizer que apontam para uma Esperança Escatológica pela qual podemos compreender o conflito das interpretações e o valor da negação na constituição do pensar e do conhecer.

É interessante marcar que para Ricoeur, apesar desses temas fronteiriços, como esperança, escatologia, culpa, falta, religião, Deus. O filósofo não deve ser um pregador profético e nem lhe é permitido apontar para tal via. Ele apenas deve ser manter no meio do caminho entre o ateísmo e a fé, pois não pode se contentar com em colocar lado a lado uma hermenêutica redutora, 
que destrói os ídolos e uma hermenêutica positiva que vai além da morte de um Deus moral. O trabalho do filósofo é pensar através de todas as antinomias presentes nesses temas para encontrar uma mediação entre a religião e a fé através de um ateísmo.

O que é uma escatologia? Ela trata dos últimos eventos da história do mundo, ou melhor, do destino do gênero humano. Ricoeur coloca que para Paulo

a justificação 'futura' (escatologia) é já imputada ao homem que crê; deste modo o homem 'declarado' justo é 'torna-se' realmente e vivamente justo, vitalmente justo. Não há, portanto, lugar para opor o sentido forense e escatológico da justiça ao seu sentido imanente e presente: para Paulo o primeiro é a causa do segundo, mas o segundo é a plena manifestação plena do primeiro; o paradoxo é o cúmulo da exterioridade coincida com o cúmulo da interioridade; dessa interioridade à qual Paulo chama nova criatura, liberdade ( RICOEUR, 2013, p. 345).

A justificação, assim, é o presente que comanda uma retrospecção sobre o tempo passado em relação ao pecado (presente). A espera de uma salvação futura vida para lá de um tempo passado superado. Podemos dizer que a perspectiva Escatológica para a solução do mal muda o foco do indivíduo para uma sociedade, da história singular para a história humana. $\mathrm{O}$ mal, assim, não é somente um dado ligado a uma pessoa, mas a uma comunidade. Esse deslocamento da dimensão pessoal para comunitária dá uma reconciliação final a história como todo. $\mathrm{O}$ evento da ressurreição de Cristo tem um valor cósmico e outro pessoal, por ser ele como diz Paulo: primogênito de toda criatura.

Temos que considerar que o paradoxo humano é origem de vários pontos de tensão que não são resolvidos e que faz da razão impotente em oferecer uma resposta. O homem sempre se apega a todo signo de felicidade pelo qual pretende apagar os seus desejos infinitos. Diante da experiência dolorosa da vida existem sempre uma tensão em contraposição a uma solução definitiva dos conflitos que o obriga a ter em conta essa exigência e a realiza-la tanto na história individual como comunitária. 
A experiência da culpa e do pecado é a experiência do mal que está alicerçada no terreno religioso e que por essa, o homem, vislumbra uma via de libertação prometida e sustentada pela Esperança que só pode ser visto no âmbito do sagrado. Conforme Ricoeur diz: "A religião possui um (...) discurso sobre o mal. Esse discurso mantém-se todo inteiro no interior do perímetro da promessa e sob o signo da esperança” (RICOEUR, 1999, p. 427). Pensar a liberdade segundo a esperança é inseri-la no movimento de abertura ao futuro do evento da Ressurreição de Cristo. $\mathrm{Na}$ dimensão religiosa, a esperança encara a salvação como um dom e não como uma dúvida autojustificável legal. O aspecto religioso da existência está envolto pela Esperança escatológica.

Diga-se de passagem, que mesmo a "esperança laica" parece superar uma visão puramente ética do esforço histórico e moral do homem para aprofundar o significado mais profundo da aventura humana dentro de uma perspectiva temporal e coletiva. A dimensão religiosa da vida e da história abraça uma concepção mais completa da existência do homem.

Uma esperança que se qualifica como escatologia não pode ser concebida e inserida somente no âmbito religioso, o sagrado. A "escatologia profana” pode ser individual ou social, mas não cósmica, que ultrapassa a história, pois é centrada unicamente no homem, e o homem é um ser limitado, histórico e contingente. Assim, somente uma escatologia do tipo religiosa pode ser capaz de oferecer uma solução definitiva e total pois essa faz referência a Transcendência do todo, ou seja, não há limite.

Kant ofereceu em sua ética alguns pontos para conciliação que dá uma completude ao destino humano. Isso se verifica quando ele unifica os elementos que eram separados pelo rigorismo ético: "a virtude, isto é, a obediência ao puro dever, e a felicidade, isto é, a satisfação do desejo. Esta reconciliação é o equivalente kantiano da Esperança” (RICOEUR, 1999, p.427).

Ricoeur, através dessa Esperança escatológica, supera Kant, pois os pontos desse último permanecem vinculados ao homem, enquanto que a esperança escatológica vem como um dom.

O homem no limite da pura razão não encontra suficiente recursos para alcançar o cumprimento do seu destino. Ante a irregularidades racional 
e técnica que amarra facilmente o homem no agnosticismo e no desespero. A angústia existencial cede lugar a um razoável otimismo acerca da possibilidade de realização final do homem e do cosmo, vencida pelo impacto filosófico da esperança do "último dia". No coração do agnosticismo está a tristeza do infinito, pois "o homem é a Alegria do Sim na tristeza do finito" (RICOEUR, 1960, p.156). É ainda clareada por Ricoeur quando diz:

Ah! Por que não posso pegar tudo e abraçar tudo! Como é cruel escolher e excluir! Assim é a vida: de amputação em amputação; e no caminho possível ao real não há senão esperanças arruinadas e poderes atrofiados (RICOEUR, 1950, p. 420).

Essa tristeza vem superada pela afirmação originária que alcança a profundidade do ser com uma liberdade que está preparada para o radicalmente nova.

O homem é um sofredor dentro de uma perspectiva finita e parcial do mundo e dos seus valores. Desse sofrimento, nasce uma continua tensão oposta ao infinito que lança o homem a sua órbita. Mas dentro de si e dos paradoxos, o homem não pode harmonizar-se para alcançar a completude a que aspira. É na finitude da história que existe uma perspectiva escatológica na qual o homem tende a superar todos os conflitos e limites que o impede de mergulhar na dimensão infinita. $\mathrm{O}$ mal, assim, é mais poderoso entrave.

A história humana é marcada pela busca teórica e prática em superar os limites que impedem a realização da felicidade plena. A história não cansa de oferecer pontos de esperança à reflexão. Conforme Ricoeur nos fala: a reflexão "inclina-nos não a um pessimismo ativo, nem a um otimismo trágico - o que dá por fim no mesmo -, mas a um sentido épico de nossa existência pessoal resposta na perspectiva de uma epopeia mais vasta da humanidade e da criação" (RICOEUR, 1968, 113).

Podemos dizer que o sentido épico da existência humana tem um significado mais pleno no âmbito da Esperança escatológica que se desenvolve à luz de deus criador e pai, pois "a paternidade está posta no domínio de uma teologia da Esperança" (RICOEUR, 1950), p. 479). Todos os planos que se colocam fora dessa perspectiva são incapazes de dar uma resposta totalmente válida, pois não são respostas definitivas. É necessário ir às fronteiras da filosofia para constatar tal fato. 
Ter um sentido épico da existência significa aceitar o conflito como uma lei permanente da história em vista de uma superação Escatológica, sem buscar ilusões de reconciliação.

O conflito aparece pela constituição originária do homem, pela sua desproporção, e dessa forma, está no tempo da história, não pode ser definitivamente vencida, mas somente superada de vez enquanto e na maioria das vezes experimentada na tensão. $\mathrm{O}$ homem não pode deixar de viver essa tensão em uma espécie de uma dolorosa dialética ente o seu ser frágil e a sua aspiração infinita. Assim, o homem percorre o caminho da história, a humanidade percorre a história da terra na Esperança que orienta à conquista definitiva na escatologia.

A morte revela a maior derrota e a suprema revelação dos limites do homem. Ela nos move a ver um transcender dos limites do espaço e do tempo, a tomar consciência dos valores da vida. De fato, "a minha vida não me parece ser um valor quando é ameaçada, ameaçada pela morte e transcendida por parte de outros valores" (RICOEUR, 1950, p. 116). Assim, a morte é capaz de invocar a esperança que é quase o seu contrário. Ao lado da angústia vital da morte, da angústia física causada pelo sofrimento, da angústia metafísica pelo temor que prevaleça a cólera de Deus em vez do amor, se põe a esperança. Essa vence todas angústias que se soma a angústia existencial derivada da consciência de culpa, porque tem sua origem no Deus, no deus da Promessa. Pois, “(...) o olhar da fé sobre os acontecimentos e sobre os homens é essencialmente benevolente. A fé dá finalmente razão ao homem da Aufkärung para quem, no grande romance da cultura, o mal faz parte da educação do gênero humano” (RICOER, 1999, p. 429). Vale também lembra que Ricoeur diz que: “a bondade de Deus é a última ideia conquistada e talvez ela só o seja como uma esperança, como termo último (...) Muitos 'crentes' chegam muito fácil e familiarmente à bondade do 'bom Deus"' (RICOEUR, 1968, p. 308).

A esperança não corre em busca de um Deus consolador, desmitologizado pelo mundo moderno, mas que evoca uma dimensão religiosa da vida. Ao aceitar uma desmitologização que procede da natureza mesma da esperança cristã, o homem faz sua parte sabendo que "o futuro já começou em Jesus Cristo; a nova época tem a sua raiz no agora no evento crístico" (RICOEUR, 1999, p.381). 


\section{A Esperança e sua abertura à história}

A visão da Bíblia, como texto a ser lido e interpretado, é o núcleo da promessa. Esse núcleo contém uma perspectiva escatológica. Essa tem uma dupla dimensão: profética com sua Esperança intra-histórica e de vários tipos apocalípticos, outra é a história como término final de tudo.

A visão religiosa do mundo conserva uma dupla relação com a história: a religião do nome, que fala do Deus da promessa e abre a história a uma perspectiva escatológica. A religião do ídolo, ao invés, atesta a manifestação de Deus, mas não faz mais que confiar uma natureza plena de deus. $\mathrm{O}$ tipo de religião que pode melhor ajudar ao homem não é aquela que clama ao deus do ídolo, mas aquela que tem fidelidade a um Deus da promessa. Pois,

Quando a esta história, ela é menos a experiência da mudança de todas as coisas do que a tensão criada pela Esperança de uma realização; a história é ela própria Esperança de história, visto que cada realização é percebida como confirmação, penhor e relance da promessa; esta propõe um acréscimo, um "ainda não", que mantém a tensão da história (RICOEUR, 1999, pp. 393-394).

O homem não sabe gerir essa tensão existencial entre o cumprimento da história e os sinais da esperança e um "ainda não" no qual a realização é um objeto da promessa na qual tem um penhor. O fim a que o homem tende e que a sua consciência percebe como desejo de totalização, é presente, de qualquer modo, nos sinais pela Esperança que é penhor daquilo que ainda não pode, mas que tende a poder. Pois, "a escatologia da consciência é sempre uma repetição criadora da sua arqueologia” (RICOEUR, 1999, 328).

Se vamos mais profundo na busca do sentido dessa arqueologia da consciência, pode-se dizer que o homem faz uma escolha, põe um ato. Ele repete, em certo sentido, uma história da humanidade centrada na sua consciência. O filósofo francês diz isso claramente quando escreve que "todos os períodos da humanidade são figurantes no concentrado da consciência” (RICOEUR, 1950, p. 141). 
O momento no qual o homem faz da sua escolha a sua consciência "reflete a seu modo a topografia social contemporânea, pela maneira que concentra a história humana" (RICOEUR, 1950, p. 141). Enquanto se procede de uma fundamental hesitação e incerteza devida a confusão corporal, cada escolha do home é feita na ordem de algo que ainda virá, na ordem de um cumprimento.

Ricoeur propõe, diante de uma escolha humana radicada em uma arqueologia e em uma projetar uma escatologia, um tríplice modo de ler a história e três níveis de leituras: o progresso, a ambiguidade, a esperança. Esses três diversos níveis de leitura vão de uma arqueologia a uma perspectiva escatológica. Pois,

(...) progresso, ambiguidade, esperança. Assinalam três cortes no fluxo da história, três maneiras de compreender, de retomar o sentido, três níveis de leitura: nível abstrato do progresso, nível existencial da ambiguidade, nível misterioso da esperança (RICOEUR, 1968, p. 10).

O progresso considera a história como um crescimento contínuo de acumulação, que pode ser algo material ou instrumental do conhecimento. Os homens em sua individualidade são postos entre parênteses.

A ambiguidade leva em consideração as escolhas do homem e a desilusões em seguir o progresso, não deixam de conduzir o homem ao limiar desse nível mais profundo e misterioso da esperança que permanece aberta ao cumprimento. Sem querer criar uma oposição radical entre o progresso e mistério e, portanto, entre esperança e progresso, a exigência da leitura da história sobre o Signo da esperança consente em "situar a Esperança cristã em relação a essa aventura aberta, incerta, ambígua” (RICOEUR, 1968, p. 10).

É importante ressaltar, também, que aqui se percebe o paradoxo da atividade do historiador: objetividade e subjetividade na escrita do passado, pois Ricoeur está se pautando nos textos cristãos.

Situando a história em relação à esperança, consentindo que ela se mantém aberta a perspectiva da história, supera-se um conceito muito redutor da história que vem limitada a uma subjetividade do indivíduo e de sua esco- 
lha. A história é precisamente a disponibilidade, a submissão ao inesperado, a abertura ao outro, que rompe o modelo de uma história reduzida à dimensão puramente subjetiva do indivíduo. Ao abrir espaço para a esperança, a história adquire a disponibilidade que se abre, que supera a subjetividade do indivíduo e os limites do tempo, pois suas consequências não se exaurem no tempo.

Isso, Ricoeur nos mostra dizendo:

Digo que o impacto filosófico da Esperança é o próprio comportamento da reflexão , que por sua vez se imprime no comportamento da composição; entendo desse modo que aquilo que a linguagem escatológica denomina Esperança se recupera reflexivamente na própria espera de todas síntese, no adiamento do desenlace de todas as dialéticas; $\mathrm{O}$ último dia , para a filosofia, não pode ser o sonho de qualquer happy end no horizonte fantasmático de nossos combates; é nesse sentido que "O Reino de Deus está próximo"; é essa proximidade que mantém aberta a história”. (RICOEUR, 1968, p. 16).

Se o homem é abandonado ao estado de tensão e de ambiguidade que experimenta em seu agir não se abrirá outra via que aquela do desespero ou da rebeldia titânica. Nessa condição, a história não tem futuro, mas somente um presente para o indivíduo e para a humanidade do momento. Somente uma leitura da história feita sob o signo da Esperança, que tende a atualizar o resultado do evento do Último dia, convém superar a ambiguidade da vida e a ilusão do progresso.

A esperança abre o sentido da história porque a liberdade dá um encerramento subjetivo e temporal nos seus últimos resultados. Essa leitura sob o signo da Esperança leva o homem à fidelidade apesar de todas suas falhas. A Esperança é otimista, pois se baseia sobre um dado fundamental da natureza humana: a bondade é o mais radical cativeiro. Assim, as soluções melhores vencerão as falsas realizações da história individual e coletiva, que a graça vence o pecado. Isso se realiza pois

(...) o sentido cristão da história não se esgota com esse sentido das decisões e das crises, da grandeza e da culpabilidade mescladas. Em primeiro lugar, por que o pecado não é o cento do credo cristão: não é nem mesmo um artigo do Credo cristão; não crê no pecado, e sim na salvação futura (RICOEUR, 1968, p. 64). 
Através da esperança nasce uma atitude de fidelidade que abre a história à perspectiva escatológica. A Esperança tem motivo de existir, pois se baseia a uma promessa na qual o homem pode esperar na superação de todas as tensões, de cada mal. A esperança se mantém aberta à história, porque lhe dá a essa um sentido mais amplo do momento, que faz com que o homem veja nos seus atos o significado que ele mesmo deixa escapar. $\mathrm{O}$ homem não vê nos seus atos, mesmo os mais nobres, um significado. A esperança concede que ele veja no seu agir um significado que supera os seus limites para caminhar em direção à sua aspiração infinita. Pois, "é a fé no Senhorio de Deus que, para o cristão, domina toda visão da história; se Deus é o Senhor das vidas individuais, é também o da história: essa história incerta, grandiosa e culposa, Deus a volta para Si”(RICOEUR, 1968, p. 64).

A esperança dá uma abertura à história, pois tira o perigo de uma solução absurda e de uma sistematização totalizante . Ao invés de ter uma alienação da história, se tem uma libertação da tentação de alienar-se no tempo e no indivíduo. A caraterística de mistério na esperança não deve ser um motivo para considera-la uma ilusão. Essa característica indica que o homem não pode confiar na razão pura se dar um sentido pleno ao seu agir. O sentido total da história não se pode dizer que seja de todo claro e revelado ao homem, caso contrário, ele será completamente mestre de seu destino; ou seja, que não resulta de sua angustiosa experiência. $\mathrm{O}$ sentido último e total da história é superior à limitada natureza do homem, mas é também indicada em seu componente infinito.

A certeza de um sentido mais profundo, em parte nascido da história, é a garantia que sustém a fidelidade do homem. Essa se mantem aberta a todos elementos que a razão humana pode adquirir e que permitem perceber o sentido pleno. A esperança, sustentada pela fidelidade do homem, permanece presa direta do aspecto dramático da vida, salvando homem de sucumbir ao desespero da incapacidade para realizar a totalidade de suas aspirações, o cumprimento completo de seus desejos, pois 
É precisamente quando a Esperança não é mais o sentido oculto de um contrassenso aparente, quando ela se libertou de toda ambiguidade, que ela recai no progresso racional e tranquilizador que ela visa à abstração morta; eis porque é necessário permanecer-se atento a esse plano existencial da ambiguidade histórica, entre o plano racional do progresso e o plano suprarracional da Esperança (RICOEUR, 1968, p. 98).

Esse plano suprarracional da esperança que fala Ricoeur é aquele da dimensão teológica. Somente uma Esperança escatológica abre o sentido nascido da história, pois vai ao limite humano no qual se constitui a história da ação humana produto que está sob o signo da ambiguidade. O olhar da Esperança Escatológica que está sobre o plano suprarracional é um olhar do homem racional que integra na sua reflexão todos aqueles acontecimentos e elementos dos seus atos para dar uma melhor compreensão.

A esperança tem seu impacto com o plano existencial concreto, pois ela é tecida nos próprios atos do homem, na sua aspiração, nos seus desejos, na sua tensão até o cumprimento. A Esperança entra no coração daquilo que parece uma insuperável discórdia que se lança na consciência filosófica. Essa mortal contradição que lacera o homem, pela Esperança pode dar uma vida a tensão que encontra seu estimulo próprio na contradição.

A reflexão filosófica ajudada pela visão da esperança tende a alargar a sua visão restrita e mortificante da existência humana na tentativa de encontra um sentido escatológico de unidade na verdade, o significado para o Último Dia.

A pregação cristã do evento da ressurreição está localizada em uma perspectiva escatológica. É necessário notar que todo discurso do novo testamento sobre o evento crístico está alicerçado nos acontecimentos do último dia, da esperança das coisas que estão por vim.

Ricoeur faz como que uma revisão dos conceitos teológicos, com base no discurso da pregação sobre o Reino de Deus que se anuncia. Ou seja, a religião no nome tem que se opor à religião do mito. A religião do nome cria uma história, a do mito se dedica a um universo cheio de deuses. A história contada em casa uma é a esperança da história, pois cada ato narrado confirma a promessa feita, um ainda não a se realizar. Existe assim uma constituição temporal 
dessa promessa. Essa promessa não é esgotada com o a vinda do Cristo, ela prossegue em uma cristologia, como evento, em uma perspectiva escatológica. A ressurreição, assim seria um evento passado, que desemborcaria na esperança escatológica. A interpretação do túmulo vazio como memorial da nostalgia.

Se podemos dizer algo sobre essa "hermenêutica da ressurreição", seria no âmbito que ela reestabelece o potencial da esperança. Pois, a tentativa de interpretar a promessa do futuro substitui a ressurreição na teologia judaica e helenística. Essa esperança em termos de promessa não é fechada em si, mas cumpre uma profecia que se abre a o evento futuro.

O evento da ressurreição é visto como ressurreição dos mortos na qual toda esperança e liberdade são vislumbradas na categoria apesar da morte. Nisso a ressurreição tem que implantar sua própria lógica que faz falta à lógica de repetição.

A esperança, em relação ao logos grego, é a-lógica, uma lógica absurda. A esperança está no campo da incerteza, uma incerteza aporética, não por uma falta, mas pelo excesso de significado. É necessário que o acontecimento da ressurreição desenvolva sua própria lógica para anular uma lógica da repetição. Assim, para Ricoeur não se pode manter uma oposição não dialética entre a promessa e o logos grego. Pois "O discurso do filósofo sobre a liberdade, que se tornaria próximo do kerygma (...) é o da religião nos limites da simples razão”. 


\section{CONCLUSÃO}

Foi interessante notar que o diálogo que Ricoeur tem com os diversos aspectos da cultura, em especial da cultura judaico-cristã, conduz-nos a uma esperança que está ancorada no evento da ressurreição.

É supreendente surpreendente atualidade no que tange os símbolos e a linguagem religiosa à ser interpretado pela filosofia principalmente contida nos textos antigos. Apesar de filósofo francês se ocupar de temas que possam soar como simples pontos do universo religioso, não significa que estes temas não tenham importância para a filosofia e que sua reflexão tenha culminado em uma teologia ou que o mesmo seja um teólogo. Pois, para ele, não se pode captar o sentido da esperança sem uma reflexão crítica que nos conduz à apreendermos o momento simbólico e da linguagem religiosa que fala o evento da ressurreição. porque tal é a aposta. Somente pode se irritar contra esse modo de pensar quem estima que a filosofia, para começar por si mesma, de ser uma filosofia sem pressupostos.

A simbólica do mal é um caso particular no âmbito da linguagem religiosa que coloca uma questão especifica ao filósofo, a dimensão trágica da existência. De uma parte, o filósofo é tentado a desqualificar os símbolos e a linguagem religiosa em nome de uma determinada razão. De outra parte, o filósofo sempre volta aos símbolos e a linguagem religiosa para descobri a sua existência dentro de uma totalidade continua.

O símbolo sempre dá à pensar algo, pois é graça a uma correspondência entre o cosmo e o homem que reflexão e símbolo dizem respeito um ao outro. Entretanto, é a superabundância de sentido do símbolo que não cessa de instruir a reflexão filosófica.

Para Ricoeur, um pensamento que parte do símbolo, mostra que esse sempre aponta para algo de que se fala. Para salvar a riqueza simbólica é necessário que o símbolo seja renovado quando cessa de mostrar os múltiplos registros: cósmicos e existencial. Dessa forma, o símbolo doa a aventura do 
ser sobre o qual o homem deve refletir. Essa reflexão é fundada sobre o ser. Por isso, o pensamento especulativo fracassa diante dos símbolos.

O problema do mal vem diretamente introduzido no discurso filosófico através da mediação da confissão da culpa e vem coligado ao problema da liberdade. $\mathrm{O}$ tema da linguagem está entre a antropologia que inspira a filosofia da vontade e o problema do mal. Diante do mal, nós temos uma tríplice possibilidade: uma aproximação pela experiência da culpa, pelos símbolos primários e pelos mitos. A experiência da culpa se dá em uma linguagem que exprime uma experiência de errância e alienação.

O poder de revelação do símbolo não se exaure na consciência de si. A simbólica permite elevar os símbolos a um patamar de conceitos existenciais. Ou seja, os símbolos não são da estrutura do pensamento, da reflexão, mas da estrutura do homem como ser. A simbólica, assim, abre para uma ontologia da finitude e do mal, pela qual se insere a dedução transcendental dos conceitos existenciais. $\mathrm{O}$ objeto de tal ontologia é a articulação da finitude com o mal humano. Isto é, refletir a partir da finitude humana, é refletir tanto o problema do mal e como o problema do ser.

O ser é o logos do qual procede o movimento retrógrado do verdadeiro, segundo as categorias que são aplicadas ao mal por Ricoeur: graças a, apesar de e quanto maior. O ser se dá no símbolo graças a uma estrutura linguística, como a do apesar de e do quanto mais, com superabundância que reenvia a uma pertença pré-linguística. $\mathrm{O}$ centro do sentido é algo que o homem pode invocar, admirar e esperar em sua cifra, mas tudo isso vêm de uma linguagem proferida pelo homem em uma poética.

Pode-se perguntar: que algo é esse que o simbolismo traduz através da linguagem? Pode-se dizer que é o esforço, a potência de existir. O logos sendo uma grandeza não homogênea, mas que constitui o ser, não pode ser poético, pois a poesia é a compreensão do mundo em ato para formar um misto de forma e de força pela qual o homem tem um sentimento. Esse sentimento se exprime através da imaginação poética esquemática. Essa consideração sobre o símbolo permite compreender melhor a metáfora porque essa está dentro de uma comunidade linguística como é o caso da expressão Reino de Deus e do 
evento da Ressureição. Esses dois mostram como o homem resiste à morte, para permanecer na vida. Esse desejo induz o homem a resistir a sua finitude e ao mal. O sentimento de ser, de continuar a existir, dada na expressão Reino de Deus e dado no evento da ressurreição, vai ao encontro do mal e da morte. O sentimento expressa, assim, a desproporção e a experiência vivida de nossa miséria. A morte é uma dimensão intrínseca à natureza humana. Ela se opõe a uma plena liberdade da consciência. Já o mal como finitude, como culpa, se constitui um limite da nossa natureza que não podemos compreender. A liberdade, então, é uma liberdade que tem limites dentro de uma temporalidade. Essa temporalidade indica o tempo temos que esperar dentro de um evento como é o da ressurreição para nossa plena liberdade.

Diante de uma perspectiva escatológica, a ressurreição não é um evento que fecha a promessa de vitória sobre a morte, mas um evento que abre que reforça e confirma a esperança. A ressureição é um evento passado que tem um lugar no futuro e de uma recapitulação final. A ressureição de Cristo aparece como o sinal, a garantia, que a promessa de ressureição é para todos.

O simbolismo, para Ricoeur, conserva em si, um sentido que nenhuma linguagem poder expressar, entretanto a nossa experiência simbólica se torna disponível, embora que superficialmente, através da articulação linguística. Pois, a capacidade que a metáfora tem em exprimir a simbólica se dá através de uma estrutura nova que permite percorrer uma nova via de conhecimento e de leitura da realidade, como é o caso do evento da Ressureição. A metáfora lê a realidade de modo centrípeto e não centrifugo. Ela lê o mundo através de uma ficção e de um redescrever a partir do sentimento, a partir da correspondência não conhecida, mas sentida entre o e o mundo. Pois, essa correspondência vem dada no símbolo que exige uma expressão linguística que, mais que dizer que coisa é a vida, diz como que coisa essa é.

A metáfora, de acordo com Ricoeur, conserva a vitalidade suficiente para explicar o símbolo, pois não ela não opera só, mas junto a uma rede simbólica. Assim, cada metáfora invoca toda uma rede. Nessa rede as metáforas ditas radicais reúnem as imagens subordinadas e coloca os conceitos a um nível 
mais elevado. As metáforas dominantes são capazes de gerar e organizar uma rede que faz uma intersecção entre o nível simbólico e metafórico.

Analisando os símbolos, Ricoeur, descobre uma estrutura ontológica que pode ser destacada pelos símbolos. Essa estrutura tem como centro a relação entre evento e sentido. Essa relação exprime-se através da linguagem poética e não poder ser reduzida. Existe assim, uma base pré-linguística em cada linguagem que não se deixa exprimir. Essa base pré-linguística é o ser como ato, como potência de existência, a isso corresponde no homem o esforço de existir e na linguagem a criatividade poética.

Toda afirmação originária, como negação existencial e desproporção constitutiva do homem, encontra cumprimento no consentimento pela finitude do homem e na conciliação com a transcendência esperada e não necessária. $\mathrm{O}$ homem em sua finitude tem motivos para esperar e para consentir. A esperança se baseia no ato pelo qual o homem aguarda algo de outro. Este algo aguardado faz com que o mundo seja uma analogia da transcendência e que possa ser admirado Entretanto, tudo depende da esperança, pois a transcendência não é o mundo, nem algo de objetivo, mas é sempre algo além. Entretanto, a esperança necessita que o homem aceite a sua condição finita como promessa e figura da transcendência. Essa promessa e essa figura vêm dadas em um evento como é o da Ressurreição como escatologia da esperança, como promessa.

É interessante notar, ao longo dos textos ricoeuriano, que a esperança surge como uma tensão à eternidade, algo presente em tudo e que atravessa a eternidade. Essa esperança perpassa todas as gerações, transcende a tudo, transcende mesmo a nossa condição finita. Essa condição finita cria, por assim dizer, o desejo de superar os limites humanos, cria o desejo de ser. Assim o homem, pela esperança, abre um horizonte pelo qual possa ter uma liberdade e vontade ilimitadas.

A ideia de Deus, assim, é uma ideia limite que se sobrepõe a liberdade. Pois ela é um exercício não violento da imaginação que se propõe educar o individuo sem violência. Deus não passa de uma descrição subjetiva, pois uma verdadeira transcendência é mais que uma ideia limite. Ela e uma presença que inaugura uma inversão na teoria da subjetividade. Essa introduz uma dimensão nova que é a dimensão poética. O homem espera quando aceita como possível para si que a necessidade que o constitui seja o mundo no qual Deus o doa. Dessa forma, a esperança abre ao homem a possibilidade de um mundo transfigurado, 
de um mundo reconciliado, no qual deve se reconhecer. Este mundo exige, por um lado, uma aposta, pois o homem, com razão descobre a contingência e por outro lado exige uma linguagem que supere os limites da razão, sem desprezá-la.

O problema do mal, introduz uma radical contingência que subverte a eidética da vontade, em busca de uma resposta empírica da vontade serva que se encontra nos mitos e nos símbolos e, por fim, em uma linguagem religiosa. $\mathrm{O}$ recurso à linguagem se deve ao problema da verdade em cada linguagem encontra e pretende dar sentido, mas de ser verdadeira. $O$ filosofo ao contrário do teólogo, deve se interrogar sobre o valor da linguagem religiosa que ao ser usada expressa os problemas radicais do homem, pois é a partir dela que podemos temporalizar os acontecimentos no passado, presente e futuro.

A linguagem religiosa, na qual a dimensão objetiva e o objeto são distintos e opostos, e na qual o sentimento do sujeito é descrito paradoxalmente, se exprime de maneira particular e dela surge, particularmente, a dimensão da existência humana que transpassa as barreiras da morte. A experiência religiosa que se exprime através dos símbolos e da linguagem exprime o sentimento de dependência absoluta, de preocupação ultima no horizonte de toda decisão que espera a despeito de tudo.

Considerada do ponto de vista escatológica a liberdade é uma escolha, algo diferente que uma decisão existencial. A decisão implica toda a liberdade se compreende diante da paixão pelo possível. Cada decisão humana é um sinal de esperança de que a sua liberdade se realize plenamente. Assim, a liberdade se encontra diante de um futuro que é ditado pelas suas decisões presentes que constituem a preparação e o seu anúncio.

Diante da religião, a filosofia pensa nos limites da simples razão e por isso submete a obra escrita, os textos religiosos, à razão, pois o logos, se podemos dizer o logos de Cristo não pode ser posto, pelo filosofo, na interpretação da obra, sem uma razão integral.

Ao filósofo cabe colocar em relação de proximidade ao discurso kerygmático, escutando-o, a fim de elaborar um pensamento, sem aceitar a fé, mas somente uma pré-compreensão cultural. Não que o discurso filosófico se subordine à teologia, mas que se coloque em relação de proximidade com o discurso kerygmático. E nisso o discurso sobre a esperança é um discurso sobre a liberdade que mentem uma articulação com a noção de esperança escatológica. 
Assim, nessa pesquisa, entendemos que a noção de escatologia e de esperança são vetores, no discurso, existenciais de renovação, vetores que quebram a igualdade dos sistemas fechados e que tem um poder de reorganização do sentido.

Essa pré-compreensão nos leva a uma anuncio escatológico e a revelação de Deus com promessa em oposição aos deuses das religiões epifanicas. A revelação gera uma história, na qual o cumprimento e sempre esperando no evento da ressureição. Esse evento vem a confirmar a esperança. O evento da Ressureição é o sinal que a promessa e para todos e o sentido do seu advento, na "morte da morte", é, consequentemente a esperança.

A liberdade à luz da esperança no evento da ressureição tem um ponto de vista puramente filosófico, enquanto se considera como uma imaginação criadora da possibilidade que vence o primado da necessidade. $O$ centro kerygmático da liberdade, dentro de uma leitura filosófica, pertence à ordem existencial da ressureição enquanto comporta que cada esperança é esperança a despeito da morte, a qual conserva todo seu trágico e realidade. Porém, a morte é negada pela esperança, pois a vitória sobre a morte é selada pelo próprio sinal do seu contrário a cruz, consequentemente dá uma esperança que não é só paixão pelo possível, uma decisão que implica toda liberdade, mas negação da morte. Cada decisão humana aparece como um sinal de esperança. A esperança pertence à lógica da superabundância, quanto mais, e supera cada possibilidade pensada pelo homem. Pensar uma esperança no evento da ressureição é pensar uma liberdade segundo uma esperança que se encontra nos limites de uma simples razão e no limite da razão.

A esperança cristã é caracterizada pelo escathon, que cumpre a história sem pertencer a ela. Essa esperança dentro de um evento como o da ressureição, do ponto de vista filosófico, é um sentimento racional, pelo qual o homem se percebe que não resulta de um saber absoluto. A filosofia acolhe a esperança como razão reguladora da reflexão que abre continuamente à reflexão para que não caia na religião nem nos ídolos. Por isso, podemos dizer com Ricoeur "a esperança não é o triunfo do dualismo, mas o viático no caminho da conciliação” (RICOEUR, 1950, p.452). 


\section{Referências}

\section{Obras de Paul Ricoeur consultadas}

RICOeUR, Paul. O conflito das interpretações. Ensaios de Hermenêutica I, Porto: RES, 1999.

RICOeUR, Paul. Du conflit à la convergence des métodes en exégèse biblique, in: Exégèse et herméneutique, X.L, Paris: DUFOUR, 1971, pp. 35-53 (Arquivo disponibilizado em pdf pela Fonds Ricoeur, 83, boulevard Arago, Paris).

RICOeUR, Paul. Creativity in Langage, Word, Polysemy, Metaphor, in Philosophy Today vol. 12 n², 1973, pp. 97-101.

RICOeUR, Paul. Évenement et sens, in Archivio di filosofia, 1971, pp. 15-34.

RICOeUR, Paul. A fllosofia e a especificidade da linguagem religiosa. Trad. João Alvares Goes, in: http://plasrt.sersanford.edu.pt/intries/Ricoeur filosofiaelinguagem/ acesso em 15 de fevereiro de 2015 às $23 \mathrm{~h}$.

_ RICOeUR, Paul. A hermenêutica bíblica. Trad. Paulo Meneses, São Paulo: Edições Loyola, 2006.

RICOeUR, Paul. Hermenêutica Filosofica e Teologica. Trad. António Missi. in: Arcabouços Filosóficos, Porto: CDD, 2013a.

RICOeUR, Paul. Hermenêutica da Ideia de Revelação in Escritos e Conferências 2: hermenêutica. Trad. Lúcia Pereira de Souza, São Paulo: Edições Loyola, 2011, pp.145-195.

RICOeUR, Paul. Hermenêutica e ideologias. Trad. Hilton Japiassu. Petrópolis: Vozes, 2008.

. Hermenêutica Filosófica e Hermenêutica Bíblica, col. Filo-

sofia Contemporánea. Porto: Nouss, 2013b. 
RICOeUR, Paul. História e Verdade. Trad. F. A. Ribeiro, Rio de Janeiro: Companhia e Editora Florence, 1968.

RICOeUR, Paul. Os incidentes teológicos as pesquisas atuais concernentes à linguagem. Trad. João Alvares Goes, in: Artigos de Filosofia Contemporánea traduções. Lisboa: Solessolares, 2015. (Publicado como : Les incidences théologiques des recherches actuelles concernant le langage. Polycopié, Paris : Institut d'études Oecuméniques, 1969).

RICOeUR, Paul. Da interpretação: Ensaio sobre Freud. Rio de Janeiro: Imago, 1977.

RICOeUR, Paul. Jean Nabert: une relecture. In: CAPELLE, P. (ed.) Jean Nabert et la question du divin. Paris: Cerf, 2003. Posface, p. 143.

RICOeUR, Paul. Karl Jaspers et la philosophie de l' existence (em colaboração com M. Dufrenne) com Prefácio de K, Jaspers, Paris: Éditions du Seuil, 1947.

RICOeUR, Paul. Leituras 3: Nas fronteiras da filosofia, trad. Nicolás Nyimi Campanário São Paulo: Edições Loyola, 1996.

RICOeUR, Paul. Manifestation et proclamation in E. Castelli, Il sacro: studie ricerche, no2 Padova: Arq. di filosofia, 1974.

RICOeUR, Paul. Prefácio, in Ideologia e poética. Marxismo e hermenêutica para a linguagem religiosa, XII. Tradução para português por João Alvares Goes, in: $<$ http://plasrt.sersanford.edu.pt/intries/Ricoeur / >acesso em 24 de janeiro de 2015 às $10 \mathrm{~h}$.

RICOeUR, Paul. Philosophie de la volonté I. Le volontaire et L involontaire, Paris: Aubier/ Montaigne, 1950.

RICOeUR, Paul. Philosophie de la volonté : Finitude et culpabilité 1- L'homme faillible, Paris: Aubier, 1960.pp. 08-162 
Philosophie de la volonté : Finitude et culpabilité 2- La symbolique du mal, Paris: Aubier, 1960.pp. 163-488.

RICOeUR, Paul. A simbólica do mal. Trad. Hugo Barros e Gonçalves Marcelo, Lisboa: Edições 70, 2013c.

RICOeUR, Paul. Do texto à ação - Ensaios de hermenêutica II. Tradução de Alcino Cartaxo e Maria José Sarabando. Porto: Rés Editora, 1994.

\section{Autores Consultados}

ALONSO SCHÖKEL, L.; SICRE DIAZ, J. L. Profetas II: Ezequiel, doze profetas menores, Daniel-Baruc-Carta de Jeremias. São Paulo: Paulinas, 1991.

ALSZEGHY, Z, M. FLICK , El hombre bajo el signo del pecado: Teología del pecado original, Salamanca, 1972.

AMHERDT, François-Xavier. L'Herméneutique philosophique de Paul Ricoeur et son importance pour l'exégèse biblique col. La Nuit surveillée, Paris: Editions du Cerf, 2004.

ANTÓN MARTIN, José Maria, El sentimento de culpabilidade en Paul Ricoeur (tese), Universidade Complutense, Madrid, 1983.

Bíblia de Jerusalém. São Paulo: Paulus, 2002.

Biblia Vulgata. Madrid: BAC, 1999.

BONACCINI, J. A. Kant e o problema da coisa em si no Idealismo Alemão. Rio de Janeiro: Relume-Dumará, 2003.

BRIGHT, John. História de Israel. 7.ed. rev. e ampl. São Paulo: Paulus, 2003.

BUBER, Martin. Eclipse de Deus: consideração sobre a relação entre religião e flosofia. Trad. de Carlos Almeida Pereira. Campinas, SP: Versus, 2007. 
, Eu e Tu, trad. Newton Aquiles Von Zuber, São Paulo: Cortez\&Moraes, 1979.

BULTMANN, Rudolf. Jesus Cristo e Mitologia. São Paulo: Novo Século, 2003.

CHANGEUX, J.P., Ce qui nous fait penser. La nature et la règle, Paris: Editions Odile Jacob, 1998.

CHIODI, Maurizio. Il camino della libertà. Fenomenologia, ermeneutica, ontologia della libertà nella ricerca filosofica di Paul Ricoeur, prefácio de Paul Ricoeur, Brescia: Morcelliana, 1990.

CLAVEL, Juan Masiá; MORATALLA, Tomás Domingo; OCHAÍTA, J. Alberto. Lecturas de Paul Ricoeur. Madrid: Pontifícia Universidade de Comillas, 1998.

DELUMEAU, Jean. O pecado e o medo: a culpabilização no ocidente (séculos 1318). Trad. de Álvaro Lorencini. Bauru: EDUSC, 2003.v.1.

DORNISCH, L., I sistemi simbolici e l'interpretazione della scritura: introduzione all'opera di Paul Ricoeur, in: Paul Ricoeur, Ermeneutica bíblica. Linguaggio e símbolo nelle parabole di Gesù, Brescia: Morcelliana, 1978, pp. 7-30

DOSSEl, François, Paul Ricoeur: Los sentidos de una vida (1913-2015). Trad. Pablo Corona, Argentina: Fondo de Cultura Económica de Argentina, S.A, 2013.

DUYCKAERTS, F. La liberté existentielle chez Jaspers, in: Morale chrétienne et requite contemporaine. Paris: Casterman, 1964.

ELIADE, Mircea. Methodological Remarks on the Study of Religious Symbolism, in: ELIADE, Mircea, KITAGAWA, Joseph M. (org.) History of Religions: Essays in Methodology Chicago: University of Chicago Press, 1959.

ELLUL, J. Le fondement théologique du droit. Paris: Delachaux \& Niestlé, 1946. 
ESLIN, Jean-Claude, Paul Ricoeur lecteur de la Bible in: Cahier 1'Herne Ricoeur 1, Paris: Essais, 2008. p. 125-135.

FAUS GONZÁLEZ, J.I., Proyecto de Hermano. Visión creyente del hombre. Santander, 1987.

Freud, S. O futuro de uma ilusão. In S. Freud, Edição standard brasileira das obras psicológicas completas de Sigmund Freud, Vol. 21, Rio de Janeiro: Imago, 1987.

FREUD, S., Cinco lições de psicanálise, Leonardo da Vinci e outros trabalhos. Trad. Durval Marcondes Vol. XI, In: https://blogpsicologiablog.files. wordpress.com/2012/01/freud11.pdf. Acesso em 10 de janeiro de 2016 às $14 \mathrm{~h}$ GILBERT, M., L'indentité narrative. Une reprise à partir de Freud de la Pense de Paul Ricoeur. Genève. Labor et Fides, 2001

GISEL, Pierre. Ricoeur, in: Estudes théologiques et religieuses 49, pp. 4. in sitio http://www.chrftusre.org/www1/ofm/sbf/edit/Kingdom/giselpierreRicoeur Update.pdf > acesso dia 23 de janeiro de 2015 às $13 \mathrm{~h} 40$.

GRAMPA, G., Nota bibliográfica, in: Ideologia e Poetica. Marxismo e ermeneutica per il linguaggio religioso, Milão: Vita e Pensiero, 1979.

GREISCH, Jean, L'Itinérance du sens, Paris, Editions Jérôme Millon, 2001

GUILLUY, J., La culpabilité fondamentale. Péché originel et anthropologie moderne, Lille, 1975.

HATMANN, N. A filosofia do idealismo Alemão. Trad. J. Gonçalves Belo. Lisboa: Fundação Calouste Gulbenkian 1983.

HEIDEGGER, MARTIN, Logos: Heráclito, fragmento 50. In: Ensaios e Conferências. Traduções de Márcia Sá Cavalcante Schuback, Emmanuel Carneiro Leão e Gilvan Fogel. 5.ed. Petrópolis: Vozes, 2008. 
HERÁCLITO, Fragmentos, in: Os Pré-Socráticos. Col. Os Pensadores. Trad. José Cavalcanti de Souza et al. São Paulo: Abril, 1989.

HERDEU Y BOHIGAS, J. Transcendencia y revelación de Dios. Metafísica de las "ifras" según Karl Jaspers, metafísica del testimonio según Jean Nabert. Barcelona: Ed. de la Facultat de Teologia, 1983.

JAVET, P., Imagination et Réalité dans la philosophie de Paul Ricoeur, in Revue de Théologie et de Philosophie 17,1967, pp. 145-158.

JASPERS, KARL, Philosophy. Trad. E. Ashton. Chicago: University of Chicago Press v.2.

JERVOLINO D., Il cogito e l'ermeneutica. La questione del soggetto in Ricoeur, Genova: Marietti, 1993.

KANT, I. A religião nos limites da simples razão. Trad. de Artur Morão. Lisboa: Edições 70, 1992.

KANT, Immanuel. Crítica da Razão Pura, Lisboa: Fundação Calouste Gulbenkian, 2001.

KIERKEGAARD, Sören. El concepto de la angustia, Buenos Aires: Libertador, 2004.

KIERKEERGAARD A Doença para a Morte, in Os pensadores, São Paulo: Abril Cultural, 1979, p. 310-450.

LEEUWEN, Theodoor Marius van, The Surplus of Meaning: Ontology and Eschatology in the Philosophy of Paul Ricoeur, Amsterdam: Editora Rodolpi, 1981.

LEVI-STRAUSS, Claude. Mito e Siginificado. Lisboa : Edições 70, 1978.

MARION, Jean-Luc. Dieu sans être, Paris: PUF, 1991. 
MOLTMANN, Jürgen. Réssurrection et avenir de Jésus-Christi in: Théologie de L'espérance. Paris: Les Editions du Cerf et Maison Mame, 1970, pp. 177-181.

NABERT, Jean, Eléments pour une Ethique, Paris: Aubier, 1962.

NARBERT, Jean. Essai sur le mal, PUF, 1955, 2ª ed., Prefácio de Paule Levert, Paris: Aubier, 1970.

PONTIFÍCIA COMISSÃO BÍBLICA. A interpretação da Bíblia na Igreja. São Paulo: Paulinas, 1999.

RAMSEY, Ian Thomas. Religious Language: An Empirical Placing of Theological Phrases, London: SCM Press, 1957.

RENAUD. Michel. Fenomenologia e Hermenêutica. O projeto filosófico de Paul Ricoeur. Revista Portuguesa de Filosofia, Braga, 41, 1985, pp. 405-442.

RIVKIN, Ellis. The Internal City: Judaism and Urbanization, Journal for the Scientific Study of Religion, 5(2):225-240, 1966.

ROCHOT, B.; GUEROULT, M., Descartes selon l'ordre des raisons, Revue d'bistoire des sciences et de leurs applications,1954,vol.7,n²,p.182 in:hptt/web/ revues/home/prescript/article/rhs_0048-996_1954_num_7_2_3417 acesso em 22/ 09/2015 às 21 h05.

SANTOS, José Henrique. O trabalho do negativo: ensaios sobre a Fenomenologia do Espirito. São Paulo: Edições Loyola, 2007.

SCHÉRER. R. L'Homme du soupçon et l'homme de foi, in: Critique 21 no 223, dez. de 1965.

SCHILLER, Friedrich, Textos sobre o Belo, o Sublime e o Trágico (Tradução, introdução, comentário e glossário de Teresa Rodrigues Cadete), Lisboa, Imprensa Nacional-Casa da Moeda, 1997. 
SICRE DIAZ,J. L. Profetas II: Ezequiel, doze profetas menores, Daniel-Baruc-Carta de Jeremias. São Paulo: Paulinas, 1991.

SCHUBERT, Kurt. Os Partidos Religiosos Hebraicos da época Neotestamentária. 2a ed. São Paulo: Paulinas, 1979.

TEXEIRA, Joaquim de Souza, Paul Ricoeur e a Problemática do Mal, Lisboa: Didaskalia, 1977.

VALERA, Juan B., Las Bases Antropológicas de Pelagio en su Tratado de las Expositiones, Publicaciones de la Universidad Pontificia de Comillas, Madrid, 1980.

VENNESTE, A., Le dogme du péché originel. Paris, 1971.

VV. AA., Commentário a la Biblia Liturgica, Roma: Edições Paulinas, 1980.

VV. AA., Lexicon - Dicionário teológico enciclopédico, São Paulo: Loyola, 1993. 


\section{Sobre o autor}

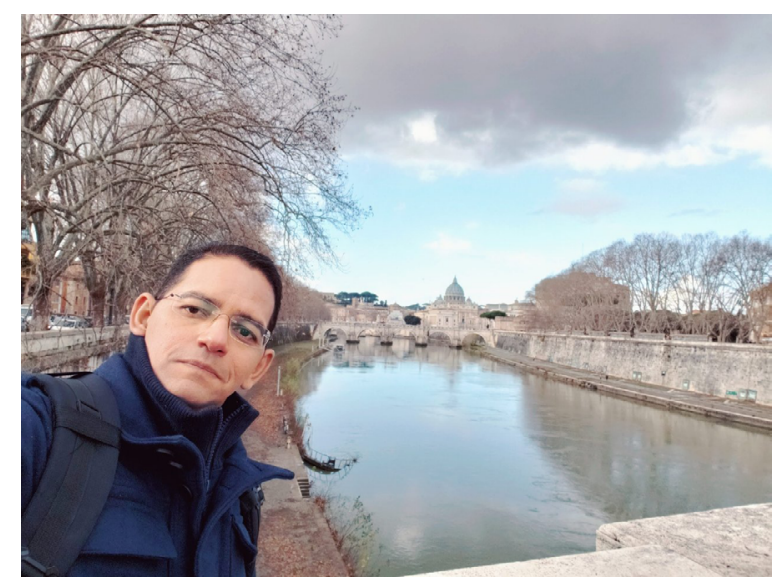

Pós-Doutor em Letras, Linguística e Discurso (UERN)/ Doutor em Filosofia/Metafísica (PUCSP)/ Mestre em Filosofia/Metafísica (UFRN)/ Avaliador do INEP/MEC para os Cursos de Filosofia e Teologia/ Cursando Bacharelado em Engenharia Civil -UNP/ Cursando Licenciatura em Música- UERN/ Especialista em Metodologia do Ensino Superior pela (FASA)/ Licenciado em Filosofia (UERN)/ Bacharel em Teologia Faculdade Católica Dehoniana/; Professor e tradutor do: Latim, Grego e Hebraico/ Disciplinas que ministra no Doutorado e Mestrado: Filosofia da Linguagem, Tópicos de Filosofia moderna Locke e os Medievais; Disciplinas que ministra graduação : Metodologia do Trabalho Científico, Ontologia I e II, Filosofia da Linguagem, Antropologia Filosófica, Bioantropologia, História da Filosofia Antiga e Medieval, Bioética, Biofilosofia, Teologia, Leitura e interpretação de Texto, Sociologia Jurídica e disciplinas relacionadas a Pedagogia. Possui projetos de pesquisa que versam sobre: Paul Ricoeur, São Tomás de Aquino, Tradução dos textos de Agostinho de Hipona, Fenomenologia da Religião, Moral Sacramental, Doutrina Social, História da Igreja Medieval, Liturgia Cristã, Ética social e ética cristã, Participe do Grupo de Teoria Política Contemporânea vinculado ao Departamento de Filosofia da UNIR. http://orcid.org/0000-0003-3902-2680 e Researcher ID:Y-3516-2018; Lattes: http://lattes.cnpq.br/3757823723460546 


\section{放UNIR}

A Fundação Universidade Federal de Rondônia (UNIR) é uma instituição pública de ensino superior criada em 1982. Ao longo de aproximados 40 anos, as ações de ensino, pesquisa e extensão formaram profissionais qualificados para atuação em todas as esferas da sociedade e do mercado de trabalho. A partir do ano 2000, com o início da oferta de cursos de Pós-Graduação, essa ação foi sendo ampliada, sendo ofertados, atualmente, 24 mestrados e 04 doutorados, abrangendo diversas áreas do conhecimento e priorizando pesquisas atinentes às questões ambientais, sociais, educacionais, culturais, econômicas e geográficas da Amazônia e especialmente de Rondônia. Como política de apoio e fortalecimento à Pós-Graduação e à pesquisa na Universidade, a Pró-Reitoria de Pós-Graduação e Pesquisa (PROPESQ) instituiu a publicação de livros elaborados pelos programas de Pós-Graduação, como atividade de divulgação e compartilhamento dos resultados das pesquisas produzidas por pesquisadores desta Instituição, tendo a Editora da Universidade Federa de Rondônia (EDUFRO), como unidade sistematizadora de todas as produções. Dessa forma, esta coleção, composta por 13 livros elaborados cada um por um PPG da UNIR, apresenta temas e abordagens disciplinares e transdisciplinares, divulga os resultados das pesquisas elaboradas nessa Instituição e aproxima a UNIR das Instituições Estaduais, Municipais e de toda a Sociedade.

Maria Madalena de Aguiar Cavalcante - Diretora de Pós-Graduação Artur de Souza Moret - Pró-Reitor de Pós-Graduação e Pesquisa

O desafio da Fundação Universidade Federal de Rondônia no ensino de graduação e de Pós-Graduação nunca foi tão grande, principalmente a partir dos recursos cada vez menores. Nesta pandemia por covid-19, o desafio foi não parar e a Pós-Graduação da UNIR não parou: defesas de dissertações e teses tornaram-se on-line e as produções acadêmicas-científicas não cessaram. Estes 13 livros da Coleção Pós-Gradução são a demonstração de que o esforço para o crescimento e a consolidação se mantém firme e constante. O futuro da Pós-Graduação na UNIR é o resultado das ações articuladas entre todos os atores, com maior abertura para a sociedade e para os setores públicos e com um grande objetivo que nos motiva, o de contribuir na formação em excelência de professores e pesquisadores nos países limítrofes. Os resultados nos colocam em papel de destaque na Amazônia e é isso o que desejamos: ser uma Instituição pública e gratuita, com forte apoio da sociedade para a oferta de cursos e formações que promovam o Desenvolvimento Regional e Sustentável do Estado de Rondônia

Marcele Regina Nogueira Pereira - Reitora
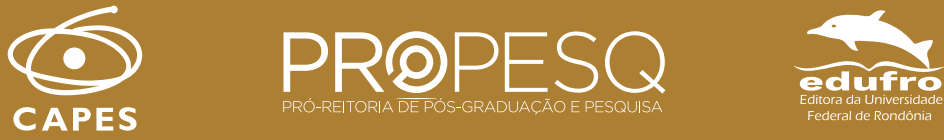